Portland State University

PDXScholar

$11-30-2020$

\title{
Microplastics in Pacific Northwest Bivalves: Ecological Prevalence, Harvester-Consumer Exposure, and Aquarium Exhibit Outcomes
}

Britta Rahel Baechler

Portland State University

Follow this and additional works at: https://pdxscholar.library.pdx.edu/open_access_etds

Part of the Environmental Sciences Commons

Let us know how access to this document benefits you.

\section{Recommended Citation}

Baechler, Britta Rahel, "Microplastics in Pacific Northwest Bivalves: Ecological Prevalence, HarvesterConsumer Exposure, and Aquarium Exhibit Outcomes" (2020). Dissertations and Theses. Paper 5616. https://doi.org/10.15760/etd.7488

This Dissertation is brought to you for free and open access. It has been accepted for inclusion in Dissertations and Theses by an authorized administrator of PDXScholar. Please contact us if we can make this document more accessible: pdxscholar@pdx.edu. 
Microplastics in Pacific Northwest Bivalves: Ecological Prevalence, Harvester-Consumer Exposure, and Aquarium Exhibit Outcomes

by

Britta Rahel Baechler

A dissertation submitted in partial fulfillment of the requirements for the degree of

Doctor of Philosophy

in

Earth, Environment and Society

\author{
Dissertation Committee: \\ Elise Granek, Chair \\ Eugene Foster \\ Max Nielsen-Pincus \\ Kathleen Conn \\ Erin Shortlidge
}

Portland State University

2020 


\begin{abstract}
Up to 23 million metric tons of mismanaged plastics enter the global ocean annually. Microplastics (MPs; $<5 \mathrm{~mm}$ ) are small plastic particles generated either intentionally during manufacture or as a result of larger macroplastics ( $>5 \mathrm{~mm})$ degrading. MPs leak into the environment and now pervade every corner of the earth, with implications for animal, plant, ecosystem and human health. It is important to understand localized environmental MP prevalence, distribution and organismal uptake in order to determine the extent of MP pollution, and ultimately unlock solution sets to reduce transmission of MPs into the natural world. In Chapter 2, I quantified MP types, concentrations, anatomical burdens, geographic distribution, and temporal differences in Pacific oysters (Crassostrea gigas) and Pacific razor clams (Siliqua patula) from 15 coastal sites in Oregon (OR). Both of these species are integral to culture, economy, gastronomy and food security along the United States West Coast. In Chapter 3, I quantified MPs in Pacific razor clams collected from 8 Olympic Coast, Washington (WA) sites, administered questionnaires to recreational razor clammers and subsequently estimated annual MP exposure of those Olympic Coast razor clam harvester-consumers surveyed. In Chapter 4, I designed and installed an educational ocean plastic exhibit at the OR Coast Aquarium. I evaluated time spent in the exhibit, number of times panels were read or interactive elements were touched, determined current and intended singleuse plastic reduction and plastic stewardship actions by visitor demographic, gauged
\end{abstract}


visitor learning after the exhibit experience and recorded suggestions for exhibit improvement.

MPs were present in Pacific oysters and razor clams from all 23 (15 OR and 8 WA) sites studied in Chapters 2 and 3. Among all clams and oysters studied in both OR and WA, over $99 \%$ of MPs encountered were fibers. In OR bivalves, whole oysters and razor clams contained an average of $10.95 \pm 0.77$ and $8.84 \pm 0.45 \mathrm{MP}$ pieces per individual, or $0.35 \pm 0.04$ and $0.16 \pm 0.02 \mathrm{MP} \mathrm{g}^{-1}$ tissue, respectively. Spring-collected oysters contained more MPs than summer-collected oysters. In WA razor clams, average MP burden for whole clams was $6.75 \pm 0.60 \mathrm{MP} /$ individual and for cleaned clams (rinsed with guts and gills removed) was $3.44 \pm 0.25 \mathrm{MP} /$ individual.

The number of razor clams consumed per meal by WA razor clam harvesters was $4.27 \pm 0.27$, which varied by gender and ethnicity, but not income or age. Harvesters ate 0-209 meals/year of razor clams, and $88.3 \%$ of respondents fully cleaned razor clams before consuming them. Annual suspected MP exposure for razor clam harvesterconsumers was 60-3,070 pieces for cleaned and 120-6,020 for whole clams.

Within our OR Coast Aquarium ocean plastic exhibit, children (0-17 years) touched the three interactive podia more than adults (18-80+ years) and adults read informational panels more frequently than children. Adult visitors increased their desire to help address the ocean plastic problem after interaction with our exhibit and reported willingness to change one or more of the single-use plastic or plastic stewardship actions, with nearly $40 \%$ intending to increase use of reusable straws and contribute to cleaning the beach. Of all age groups (18-29, 30-39, 40-49, 50-59, 60-69, 70-79), 18-29 year 
olds had the highest change in desire to help address the ocean plastic problem before and after seeing the exhibit, but the lowest likelihood of engaging in single-use plastic reduction or plastic stewardship actions, highlighting a need for targeted outreach to this specific age group. The totality of all three research chapters within this dissertation serve as important references within the growing portfolio of Pacific Northwest MP investigations, and can inform future education, outreach and policy efforts to attenuate environmental MPs and reduce household-level single-use plastic waste generation in the region. 


\section{Acknowledgements}

There are many people who deserve thanks and accolades for their invaluable assistance during the development, execution and writing of my dissertation. First, I would like to thank my advisor and committee member, Dr. Elise Granek, for the guidance and expertise she provided me during my four years at Portland State University (PSU). I would like to thank my committee members Dr. Kathleen Conn, Dr. Eugene Foster, and Dr. Max Nielsen-Pincus for their extensive and thoughtful input and guidance throughout the entire dissertation process. Thank you to Dr. Erin Shortlidge for serving as my Graduate Student Representative. Many thanks to Dr. Angela Strecker, Rich Miller and Crysta Gantz for allowing me the use of their stereomicroscope, and working with me to schedule microscope time. I am greatly indebted to Neil Jensen of Oregon Department of Agriculture and Dr. Steve Rumrill, Micah Rogers, and Alexandria Marquardt of Oregon Department of Fish and Wildlife for the many hours they put in assisting with collecting razor clam samples, and to Matt Hunter for not only assistance with digging but also for his thoughtful contributions to Chapter 2 of the manuscript. Much appreciation to Scott Mazzone, Ervin “Joe” Schumacker and Staci Bruce (Quinault Indian Nation) and John Deibert, Clayton Parson, Zach Forster and Dan Ayres (WDFW) for assistance with razor clam collection, coordination, and providing input on Chapter 3 of the manuscript. Thanks to Dr. Pat Wilkinson from the University of New Hampshire and to Dr. Susanne Brander, Emily Pedersen and Katherine Lasdin of Oregon State University for performing FTIR fiber validation work and interpretation of results in Chapters 2 and 3. . I would like to thank Dr. Pete Hodum for his advice and willingness 
to share insights to develop Chapter 2 methodologies. Thank you to Kathy Martin, Sherie Huffman and Emma Spadaro for their help with logistics, paperwork and supply acquisition. Sarah Bartlett and PSU Chemistry Stockroom staff were tremendously helpful with supply rentals and purchases necessary for Chapters 2 and 3 . Thanks to Anna Bolm, Scott Holland, Clara Orr, Julia Adelsheim, Matt Rollins, Mia Jauregui, Hannah Smiley, Devin Van Leuven, Alex Bienko, Alexandra Tissot, Rosemary Wood, and Christopher Tenorio for support with lab work and data collection for Chapters 2 and 3. Special thanks to Nini Bui for volunteering to design and create the zine cartoon booklet for the aquarium exhibit in Chapter 4 and to Hanna Gentile and Anna Young for donating their time to design and create the hanging shell art installation for the ocean plastic exhibit. I am indebted to Tina Smith, Dr. Kerry Carlin-Morgan and Katy Nalven of the Oregon Coast Aquarium for collaborating on the ocean plastic exhibit and assisting with data collection efforts. Thanks to Ashley Peterson for assistance with generating exhibit materials, and to the many Oregon Coast Aquarium staff and volunteers for assistance with exhibit setup, installation and maintenance. Thanks to Amy Ehrhart, Dorothy Horn, and Kaegan Scully-Engelmeyer for assistance with Chapter 4 questionnaire data collection. Thanks to the Applied Coastal Ecology lab group for assistance with coding Chapter 4 questionnaire data by theme and for input and support throughout my entire dissertation. Lastly, thanks to my family, friends, and the Applied Coastal Ecology lab group for all of the guidance, help, support, and the positive environment you created for me during my time at PSU. I could not have accomplished any part of this work without help from all of the incredible people listed here. Funding 
for this project was provided by Oregon Sea Grant (award \# NA14OAR4170064), the Edward D. \& Olive C. Bushby Scholarship, Oregon Chapter of the American Fisheries Society, the Sustainable Fisheries Foundation, the Puget Sound Anglers: Fidalgo - San Juan Chapter, Oregon State University's Hatfield Marine Science Center, the PSU Institute for Sustainable Solutions. Funding for publication of Chapter 3 in an open access journal was funded by the Portland State University Library's Open Access Fund. 


\section{Table of Contents}

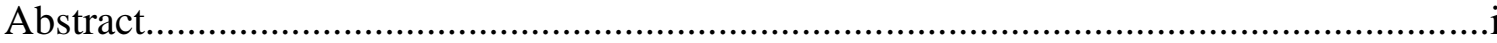

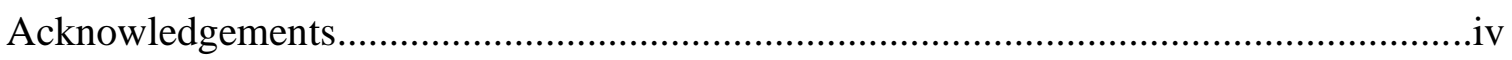

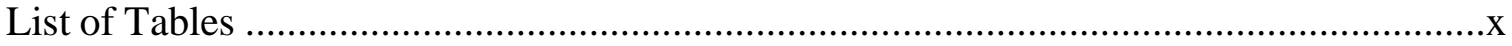

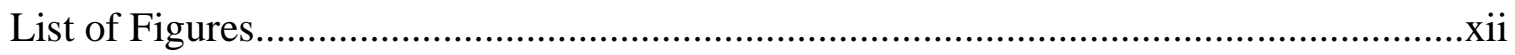

Preface

Chapter 1:

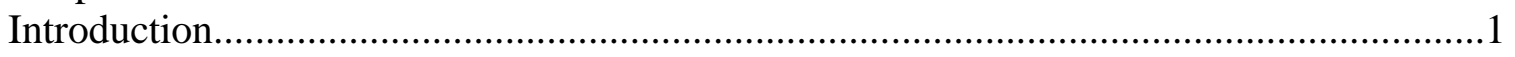

Chapter 2:

Microplastic Concentrations in Two Oregon Bivalve Species-Spatial, Temporal, and

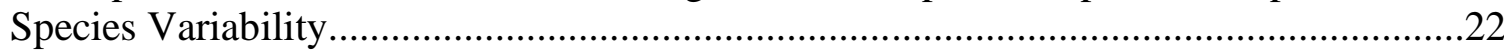

Chapter 3:

Microplastic Exposure by Razor Clam Recreational Harvester-Consumers Along a Sparsely Populated Coastline.......................................................................................56

Chapter 4:

Aquarium Visitor Engagement with an Ocean Plastic Exhibit: Effects on Self-Reported Single-Use Plastic Reductions and Plastic-Related Environmental Stewardship

Actions.

Chapter 5:

Conclusions.

Appendices.

Appendix A: Chapter 2. Biological information for Pacific oysters and razor clams collected at each sample site in April (Spring) and July (Summer) 2017

Appendix B: Chapter 2. Sources, averages, and ranges of microplastic contamination in Pacific oyster and Pacific razor clam samples.

Appendix C: Chapter 3. 2010 Land use cover $\left(\mathrm{km}^{2}\right)$ for the four coastal counties located on the Olympic Peninsula, WA. Counties are ordered north to south. Razor clam sample site names are listed below their respective county names. No razor clam sites were located in Clallam county. Data was obtained from NOAA's Digital Coast at: https://coast.noaa.gov/digitalcoast/tools/lca.html. 163 
Appendix D: Chapter 3. Schematic of the two microplastic (MP) contamination quantification techniques employed in this study. Procedural controls were deionized water filtered to $50 \mu \mathrm{m}$ and run through the same process as all other samples. Microscope blanks were glass petri dishes filled with filtered DI water, placed on the microscope base, and left open to the air during visual inspection of samples for MPs....

Appendix E: Chapter 3. Five-page structured questionnaire administered to Olympic Coast razor clam harvesters in April 2018 at Mocrocks and Copalis Beaches, Olympic Peninsula, Washington, United States

Appendix F: Chapter 3. Number and percentage of Olympic Coast questionnaire respondents that consumed marine shellfish species or species groups. Consumption frequency is ordered from most to least frequent.

Appendix G: Chapter 3. Example photos of suspected microplastics (MPs) extracted from Olympic Coast razor clams (top) and total counts of each MP category encountered (bottom) in the 4 razor clam sample types included in this study (whole, cleaned, guttissue only, tissue-only). Black bars represent a length of $0.5 \mathrm{~mm}$ in each of the images shown.

Appendix H: Chapter 3. Numbers and percentages of suspected microplastics identified in 138 Olympic Coast razor clam samples $(n=799)$ by color. Colors in figure correspond to actual colors encountered: colorless $(n=441 ; 55.19 \%)$, blue $(n=154 ; 19.27 \%)$, gray $(n=98 ; 12.27 \%)$, black $(n=37 ; 4.63 \%)$, red $(n=26 ; 3.25 \%)$, purple $(n=19 ; 2.38 \%)$, brown $(n=15 ; 1.88 \%)$, green $(n=5 ; 0.63 \%)$, and pink $(n=4 ; 0.50 \%)$.

Appendix I: Chapter 3. Characteristics, material types and FTIR spectral match percentages for 53 randomly-selected suspected microplastics isolated from Olympic Coast razor clams. Results are sorted by FTIR \% top match from highest to lowest......172

Appendix J: Chapter 3. Example FTIR-ATR spectra of microplastics isolated from Olympic Coast razor clams, stacked along with the two highest percentage matches from Omnic, Primpke et al. 2018 and Primpke et al. 2020 FTIR polymer databases for a: A) Polyethylene Terephthalate fiber (1.9mm total length); and B) Cellulose acetate fiber (3.2mm total length)

Appendix K: Chapter 4. Aerial schematic of the ocean plastic exhibit at the Oregon Coast Aquarium. Exhibit dimensions were approximately 12 x $10 \mathrm{ft}$. 174

Appendix L: Chapter 4. Layout and content of wall panels at the Oregon Coast Aquarium ocean plastic exhibit. 
Appendix M: Chapter 4. Cartoon zine booklet created by Nini Bui and Britta Baechler for the ocean plastic exhibit at the Oregon Coast Aquarium. A laminated, spiral-bound copy was mounted to the Plastic Solutions Desk with paracord.

Appendix N: Chapter 4. Structured questionnaire administered to Oregon Coast Aquarium visitors in August and November 2019

Appendix O: Chapter 4. Conceptual diagram showing data collection options for Oregon Coast Aquarium visitors entering the ocean plastic exhibit. Structured questionnaires were administered to randomly selected individuals that verbally confirmed they were 18 years of age or older

Appendix P: Chapter 4. Datasheet for timed interaction survey data collected at the Oregon Coast Aquarium in August and November 2019.

Appendix Q: Chapter 4. Categorizations for open-ended Oregon Coast Aquarium ocean plastic exhibit questionnaire responses (Questions 3, 5, 6, 7, 9A, 10, 13, 14) thematically coded by the Applied Coastal Ecology (ACE) lab group at Portland State University. A percent agreement score for each question was generated, calculated as the percent similarity of response categorization between ACE and the paper's lead author. Final categorizations were determined by the lead author.

Appendix R: Chapter 4. Thematically categorized open-ended responses by 93 Oregon Coast Aquarium visitors for the first two- A) positive words that come to mind when you hear the word 'plastic'; and B) negative words that come to mind when you hear the word 'plastic'. Top five responses by frequency are represented in blue, remaining responses are represented in gray. Not all respondents provided two words each. Non-responses were not included.

Appendix S: Chapter 4. Mean, Median and Mode responses for 91 Oregon Coast Aquarium visitors who self-reported single-use plastic reduction or plastic stewardship actions. Actions are sorted left to right from highest to lowest mean response. $0=$ Never; $1=$ Rarely (I have done this a couple of times); $2=$ Sometimes (about once or twice a week); $3=$ Frequently (three or more days a week); $4=$ Almost every day. 


\section{List of Tables}

\section{Chapter 2}

Table 1: Number of samples analyzed and average microplastic burden in Oregon Pacific oysters and Pacific razor clams by site and season, and average, minimum, and maximum lengths of microplastics identified at each site. Pacific oyster site names are randomized and coded OY1-OY6. Pacific razor clam sites are listed by

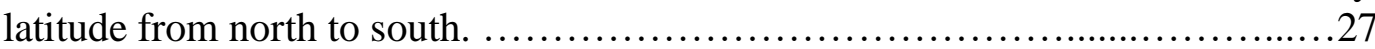

Table 2: Microplastic burden of Oregon Pacific oysters and Pacific razor clams (in number of microplastics per whole individual and per gram of whole organism tissue). Significant differences are indicated in bold

Chapter 3

Table 1: Descriptions of the four clam sample types included in this study

Table 2: The estimated annual microplastic exposure ranges by Olympic Coast, WA razor clam harvester-consumers. MP exposures were rounded to the nearest 10. The number of razor clams consumed per sitting, and minimum and maximum number of razor clam meals consumed per year were self-reported. Average number of microplastics for whole and cleaned razor clams were determined through analyses of clams collected from eight Olympic Coast sites. Minimum razor clam meals consumed include nonzero responses only.

Table 3: Themes elucidated from Olympic Coast razor clam harvester questionnaire survey responses $(n=25)$ for the question "Please expand on what concerns you have about microplastics in your food".....................................8 82

\section{Chapter 4}

Table 1: Descriptions of ocean plastic exhibit informational panels, interactive elements, and art installation........................................................... 118

Table 2: Mean responses for 91 Oregon Coast Aquarium visitors who self-reported their desire to help address the ocean plastic problem before and after seeing the exhibit. Rankings of desire to help were from $0-4(0=$ low, $4=$ high $) .87$ respondents provided zip codes. U.S. states with marine coastlines were CA, HI, OR, TX, and WA; U.S. states with no marine coastlines were AZ, ID, KY, NV, OK, UT and WI. The single respondent with a non-U.S. address (Italy) was excluded from the locality and coastal categories.

Table 3: Mean responses for 91 questionnaire respondents who self-reported single-use plastic or plastic stewardship actions (prior to seeing exhibit). Actions are sorted left to right from highest to lowest mean response for all respondents. Responses are divided by gender, age, coastal status, and locality. $0=$ Never; $1=$ Rarely (I 
have done this a couple of times); $2=$ Sometimes (about once or twice a week); $3=$ Frequently (three or more days a week); 4= Almost every day. NAs and nonresponses were excluded. There were no responses for the 80+ category. Only 87 respondents provided zip codes. U.S. states with marine coastlines were CA, HI, OR, TX, and WA; U.S. states with no marine coastlines were AZ, ID, KY, NV, OK, UT and WI. The single respondent with a non-U.S. address (Italy) was excluded from the locality and coastal categories....

Table 4: Percentage of Oregon Coast Aquarium visitors that self-reported intended single-use plastic or plastic-related environmental stewardship action changes after seeing the exhibit. Per respondent group, intended change is reported as: total percentage (number of individuals in the group reporting either probable "probably will start doing or increase", or definite - "definitely will start doing or increase" behavior change); percentage reporting probable change, and percentage reporting definite change. Groups and actions reporting $\geq 40 \%$ total change are colored green. Groups and actions where \% reporting definite change $>\%$ reporting probable change are colored blue. Age was divided into three groups based on similarity of responses. Only 87 respondents provided zip codes. U.S. states with marine coastlines were CA, HI, OR, TX, and WA; U.S. states with no marine coastlines were AZ, ID, KY, NV, OK, UT and WI. The single respondent with a non-U.S. address (Italy) was excluded from the locality and coastal categories. 


\section{List of Figures}

\section{Chapter 1}

Figure 1: Transmission of plastics into the environment: Examples of sources and routes of plastic transmission from terrestrial to aquatic environments, environmental sinks and reservoirs, and vectors of plastic transport from aquatic to terrestrial realm.

Figure 2: Plastic transmission to the environment: Process, interventions, examples of ocean plastic pollution research needs, and dissertation chapters that address one or more of the research needs presented.

\section{Chapter 2}

Figure 1: The 2017 sample collection sites along the Oregon coast delineated for Pacific oysters and Pacific razor clams [Map credit: K. Scully-Engelmeyer; Service Layer Credits: Esri, Garmin, GEBCO, NOAA, NGDC, and other contributors; Sources: Esri, USGS, NOAA] ..................................................28

Figure 2 (A-B): Number of microplastics by season ( $\mathrm{SP}=$ spring (teal) and $\mathrm{SUM}=$ summer (gold)) and species for Oregon Pacific oysters and Pacific razor clams: A) per gram of whole-organism tissue, and B) per whole organism. Welch's Ttests were run to determine seasonal intra- and inter- species differences in log transformed values. P-values show significant differences in microplastic burdens for seasons and/or species pairs indicated. $(C-D)$ : Number of microplastics in Oregon Pacific oysters (gold) and razor clams (teal): C) per gram of wholeorganism tissue, and D) per whole organism. Dashed blue line indicates average contamination level for razor clams (6.11 microplastics per sample); dashed red line indicates contamination level for oysters (5.11 microplastics per sample). ANOVA and post-hoc Tukey tests were run for each species to determine significance. P-values show significant differences in microplastic burdens for site pairs indicated. Data are combined for both spring and summer sampling periods. Reported values include background and processing fiber levels. Sites are arranged north to south by latitude. OY1-OY6: Randomized oyster sites; CLA= Clatsop Beach; CAN= Cannon Beach; MEA= Cape Meares; AGA= Agate Beach; $\mathrm{NEW}=$ Newport; $\mathrm{COO}=\mathrm{Coos}$ Bay; $\mathrm{BDF}=$ Bastendorff Beach; WHS $=$ Whiskey Run; GDB= Gold Beach. Reported values include background and processing fiber levels...

Figure 3: Comparison of sample types for summer-collected Pacific oysters (site names bolded) and Pacific razor clams. Reported values include background and processing fiber levels. Gut $=$ gut-tissue, Tissue $=$ non-gut tissue, Whole $=$ whole organism. Dashed blue line indicates average contamination level for razor clams (6.11 microplastics per sample); dashed red line indicates contamination level for oysters (5.11 microplastics per sample). Sites are arranged north to south by 
latitude. OY1-OY6: Randomized oyster sites; CLA= Clatsop Beach; CAN= Cannon Beach; MEA= Cape Meares; AGA= Agate Beach; NEW= Newport; $\mathrm{BDF}=$ Bastendorff Beach; WHS = Whiskey Run; GDB= Gold Beach.

\section{Chapter 3}

Figure 1: Modified publicly-available map of recreational and commercial razor clam beaches on the Olympic Peninsula, Washington, with razor clam collection sites (orange circles) and sites where both razor clams were collected and clam harvester surveys were conducted (yellow circles) in April 2018. Sample beaches included (from North to South): Kalaloch beach, Point Grenville beach (within the Quinault Indian Reservation), Mocrocks Beach, Copalis Beach, Twin Harbors and Long Beach. Original map source: http://wdfw.wa.gov/fishing/shellfish/razorclams/...........................62

Figure 2: Number of microplastics (MPs) by sample type. $\mathrm{CW}=$ whole clam $(\mathrm{n}=52)$; $\mathrm{CG}=$ gut-tissue only $(\mathrm{n}=24) ; \mathrm{CT}=$ tissue-only $(\mathrm{n}=23) ; \mathrm{CC}=$ cleaned clam $(\mathrm{n}=39)$. No.= number. Black hashed line indicates average microscope blank contamination (Avg=0.23 MPs/sample; $\mathrm{n}=145)$. Blue hashed line indicates average procedural control contamination (Avg=3.25 MPs/sample; $n=4)$. Bold numbers above boxes indicate average number of MPs per sample type.

Figure 3 (A-B): Number of microplastics (MPs)- (A) Per individual whole razor clam, with red line indicating average number of MPs for all eight sites (Avg= 6.75 MPs/individual), black hashed line indicating average microscope blank contamination $(\mathrm{Avg}=0.23 \mathrm{MPs} / \mathrm{sample} ; \mathrm{n}=145)$, and blue hashed line indicating average procedural control contamination (Avg=3.25 MPs/sample; $n=4)$; and (B) Per gram of tissue (wet weight), with red line indicating average number of MPs per gram of tissue (wet weight) for all eight sites (Avg $=0.15 \mathrm{MP} \mathrm{g}^{-1}$ tissue). Bold numbers above boxes indicate average number of MPs per sample type. No.= number. Sites are arranged north to south by latitude. KLA $=$ Kalaloch beach $(\mathrm{n}=$ 7), PTG= Point Grenville (within the Quinault Indian Reservation boundary; $\mathrm{n}=$ 7), $\mathrm{MOC}=$ Mocrocks Beach $(\mathrm{n}=6), \mathrm{COP}=$ Copalis Beach $(\mathrm{n}=6), \mathrm{SCO}=$ South Copalis Beach $(n=7), N T H=$ North Twin Harbor $(n=5), S T H=$ South Twin Harbor $(n=7)$, LON= Long Beach $(n=7)$

Figure 4 (A-D): From top left to bottom right- Number of Olympic Coast recreational razor clam harvester questionnaire responses by: (A) gender; (B) ethnicity; (C) income level; and (D) age group. Bold numbers above bars represent number of

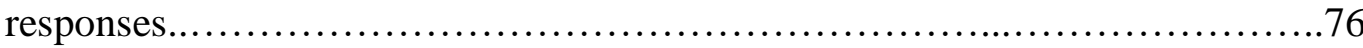

Figure 5 (A-D): From top left to bottom right- Number of razor clams consumed per sitting by Olympic Coast recreational razor clam harvester: (A) gender; (B) ethnicity; (C) income level; and (D) age group. Significant differences were 
identified between males and females (panel $\mathrm{A} ; \mathrm{p}=0.04$ ), but not by income level

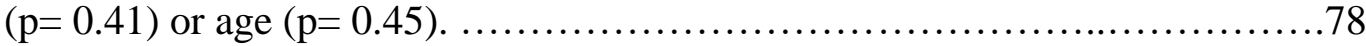

Figure 6: Ranges for the number of razor clam meals consumed per year by Olympic Coast harvester-consumers: Females $(n=46)$, Males $(n=59)$, All ethnicities combined $(n=87)$, Native American \& Alaska Native $(n=3)$, NonWhite/Caucasian (includes all ethnicities except White/Caucasian; $n=18$ ), and

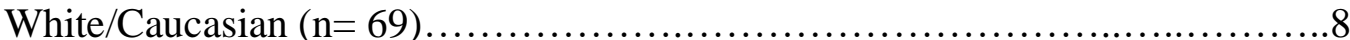

Figure 7 (A-B): Ranges of estimated annual Olympic Coast razor clam harvesterconsumer microplastic (MP) exposure for: Females $(n=46)$, males $(n=59)$, all ethnicities combined $(n=87)$, Native American \& Alaska Native $(n=3)$, NonWhite/Caucasian $(n=18)$, or White/Caucasian $(n=69)$ respondents from consumption of: (A) Cleaned razor clams with the foot and siphons cleaned and rinsed and the siphon tips, digestive organs and gills removed; and (B) Whole razor clams.

Figure 8 (A-B): Comparisons of average microplastic burdens in Pacific Northwest bivalves (Washington and Oregon, U.S. and British Columbia, Canada), in- (A) Average number of microplastics per individual; and (B) Average number of microplastics per gram of tissue (wet weight; except dry weight for Covernton et al. 2019). Gray bars indicate manila clams, blue bars indicate Pacific razor clams, green bars indicate Pacific oysters. Avg= Average, $\mathrm{MP}=$ microplastic, $\mathrm{g}=$ gram. *=All studies except Davidson and Dudas included suspected microplastic material validation using Fourier Transform Infrared (FTIR) or Raman spectroscopy. $* *=$ For general context only; calculated from Table 2 of Martinelli et al. (2020) as average of site-specific visually-identified number of particles per oyster (panel A) or per gram of tissue (panel B) for 10 sites $x$ average site-specific percentage of suspected microplastics confirmed to be plastic through Raman

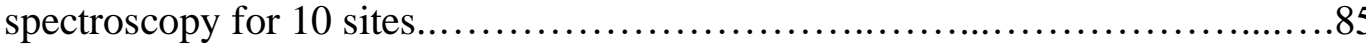

\section{Chapter 4}

Figure 1: Photo of the ocean plastic exhibit displayed at the Oregon Coast Aquarium in Newport, Oregon, U.S. from March 2019-April 2020 ......................116

Figure 2 (A-C): Layout and content of the three ocean plastic exhibit interactive podia: A) Can You Help Clean the Beach? B) Zoom in on Microplastics, and C) Plastic Solutions Desk.

Figure $3(\mathrm{~A}-\mathrm{C})$ : By age group, average $\mathrm{A})$ number of seconds spent in the ocean plastic exhibit, B) number of times ocean plastic exhibit wall panels were read, and C) number of times ocean plastic exhibit interactive podia were touched.

Figure $4(\mathrm{~A}-\mathrm{C})$ : Thematically coded open-ended responses by 93 Oregon Coast 
Aquarium visitors to the questions- A) "What do you think the Aquarium was trying to get across to you with this exhibit?"; B) "Before seeing this exhibit, I never realized that..."; and C) "Seeing this exhibit reminded me that...". Top five responses by frequency are represented in blue, remaining responses are represented in gray. Not all respondents provided answers for both questions. Non-responses were excluded from the figure.............................129

Figure 5 (A-C): Thematically categorized open-ended responses by 93 Oregon Coast Aquarium visitors for the questions: A) "What did you like best about the exhibit"; B) "If children in your group interacted with the exhibit, what did they like best?"; and C) "Were there any parts of the exhibit you felt were confusing and how could the exhibit be improved?". Top five responses by frequency are represented with blue bars, remaining responses are represented with gray bars. Non-responses due to no children in the group were not included in Figure 5B. Note: the microscope light did not work during the August sampling period....137 


\section{Preface}

This dissertation is written in the format of individual manuscripts for Chapters 2, 3, and 4; as such, appendices, acknowledgements, references and supplementary materials corresponding to each Chapter can be found at the end of that Chapter's text. Chapter 2 was an invited paper to the Limnology \& Oceanography Letters Special Issue titled 'Microplastics in marine and freshwater organisms: Presence and potential effects', and was published in February 2020 at doi:10.1002/1ol2.10124. Chapter 2 data are available in the PDXScholar data repository at https://doi.org/10.15760/esm-data.1.

At the time of dissertation submission, Chapter 3 was accepted for publication in Frontiers in Marine Science: Marine Pollution (Oct 23, 2020), and Chapter 4 was submitted for publication to Environmental Education Research (October 6, 2020). Some repetition of abstract and introductory information may be present due to the manuscriptstyle format of dissertation Chapters. 


\section{Chapter 1: Introduction}

Plastics are synthetic materials comprised of a series of monomers which together make polymers (Thompson et al. 2009). The first fully synthetic plastic was developed in the early 1900's and was coined Bakelite (Crespy et al. 2008). Large-scale plastic production began in earnest in the mid-twentieth century and has increased exponentially since (Gu and Ozbakkalogu 2016), from an estimated annual output of 2 million metric tons per year in 1950 to 380 million metric tons per year in 2015 (Geyer et al. 2017). Plastics now have many important uses and benefits and have become integrated into every facet of modern life and the human experience; as such, sharper increases in plastic production are expected and may eclipse 500 million metric tons per year by 2050 (Geyer et al. 2017; Lau et al. 2020; Napper and Thompson 2020). Unfortunately, widespread reliance on plastics and failure of governments to effectively regulate production and recycling of most plastic products have led to a high propensity for mismanagement. In 2015, 4.9 billion metric tons of plastics filled landfills and polluted the environment globally; by 2050 that number could climb to over 12 billion metric tons per year (Geyer et al. 2017).

Macroplastics, widely defined as plastics greater than $5 \mathrm{~mm}$ in any linear dimension, break down in the environment when subjected to heat, light, and environmental forces such as wind, wave, UV, biological and mechanical disturbances, into microplastics (MPs; $<5 \mathrm{~mm})$ and nanoplastics (NP; $\leq 0.1 \mu \mathrm{m})$. MPs cannot be categorized as a single contaminant; instead, they represent a diverse suite of 
contaminants due to their highly variable chemical compositions, shapes, colors, and forms (Rochman et al. 2019). MPs are categorized as either primary (polymers intentionally manufactured to be $<5 \mathrm{~mm}$ in size) or secondary (polymers degraded from larger plastics, resulting in particles $<5 \mathrm{~mm}$ in size) particles, and exist as fragments, pellets, filaments, films, fibers or fiber bundles (Rochman et al. 2019). It is estimated that up to 23 million metric tons of mismanaged macroplastics and 1.5 million metric tons of MP unceremoniously enter the global ocean each year (Borrelle et al. 2020; Boucher et al. 2017), impacting more than 700 marine species through direct ingestion of polymers or entanglement in derelict debris (Gall and Thompson, 2015).

MPs are ubiquitous and found in terrestrial, aquatic and marine ecosystems (Figure 1). They are present in air, soil, fresh, brackish, and salt water, sea ice, glacial ice, flora and fauna, as well as numerous other environmental media (e.g. Cole et al. 2011; Rochman et al. 2015; Datu et al. 2019; Wright et al. 2020; Guo et al. 2020). These contaminants largely originate from land-based sources and frequently make their way into the aquatic and marine environment. Atmospheric deposition of MPs has been observed in urbanized areas as well as presumed pristine areas like alpine glaciers, suggesting that wind and particles in the atmosphere can carry plastics to every corner of the earth (Rochman and Hoellein 2020). Microfibers have been associated with atmospheric deposition and much higher rates of fallout occur during periods of rain, suggesting precipitation is able to 'push' airborne plastics back down to the ground (Horton et al. 2017). These once-airborne particles are transported by stormwater to nearby waterways, and out to the ocean. 


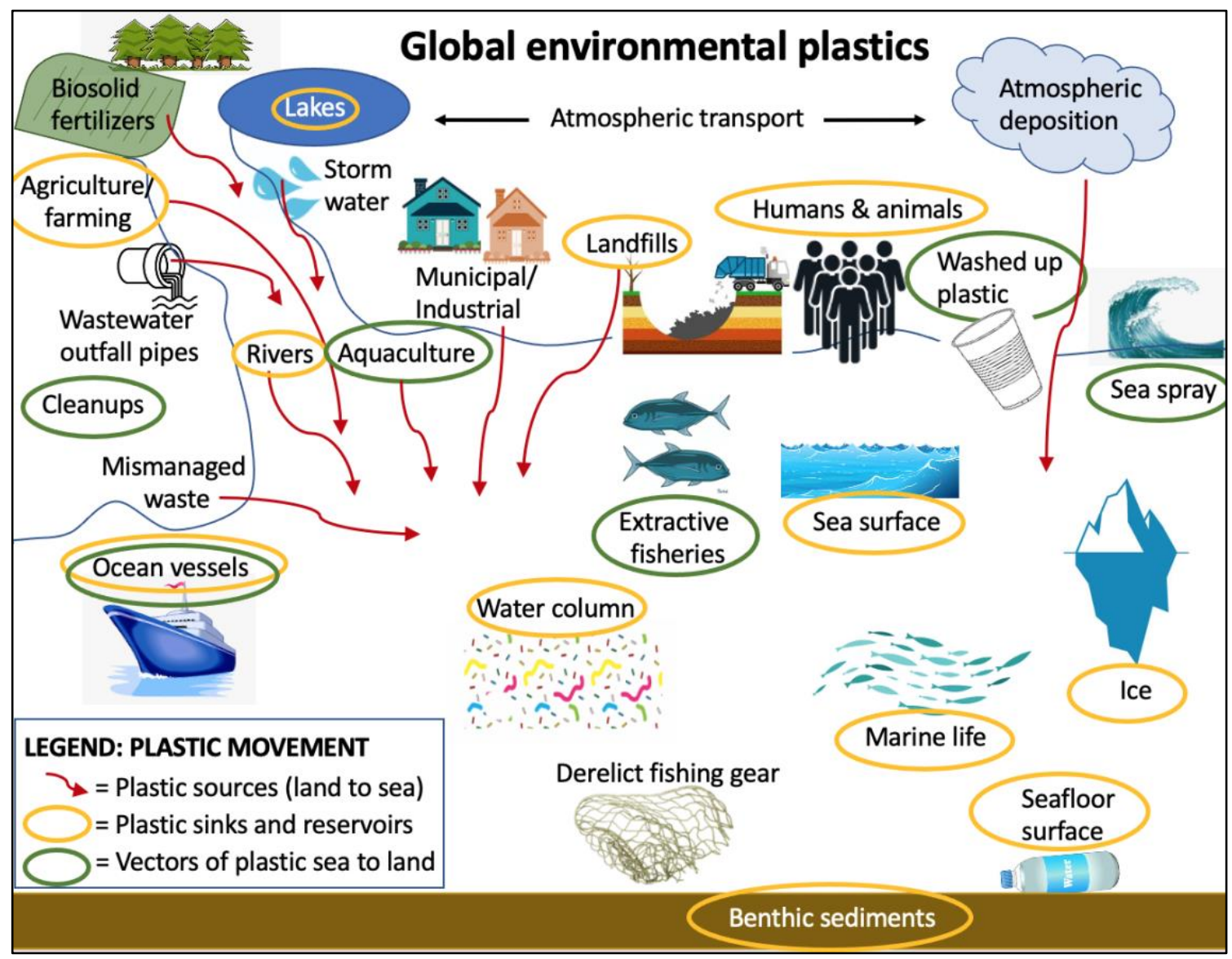

FIGURE 1. Transmission of plastics into the environment: Examples of sources and routes of plastic transmission from terrestrial to aquatic environments, environmental sinks and reservoirs, and vectors of plastic transport from aquatic to terrestrial realm.

Rivers transport up to 2.4 million tons of plastic into global oceans each year, carrying nearly 30,000 tons to the sea annually by North and Central American rivers alone (Lebreton et al. 2017). Sewage sludge applied to agricultural fields as fertilizer is a significant source of microplastics in the environment, with nearly half of the 5.9 million metric tons of microfibers generated through laundering since the 1950's applied through this method (Gavigan et al. 2020). Microplastics subsequently become air and waterborne and are able to travel long distances. Plastic-based mulches, polytunnels, and polymercoated seeds used in agriculture are also sources of plastics that can eventually break 
down and become mobile in the environment (Horton et al. 2017). Stormwater runoff and wastewater treatment plant (WWTP) effluent deliver significant volumes of MPs to coasts and oceans as well. Microfibers comprise the greatest proportion of MPs in the coastal environment, and are derived from wastewater, gray water and stormwater inputs, among other sources (Figure 1). Considering a single load of synthetic clothing can generate up to 700,000 microfibers which are flushed through gray water into WWTP (Napper and Thompson 2016), a single city or urban area could easily generate hundreds of billions of fibers per day even if wastewater is heavily filtered.

MP transmittance to the marine environment has been increasing for decades in a trend similar to global plastic production (Ostle et al. 2019). As MP abundance in oceans increase, the propensity of those particles to become bioavailable to marine organisms also increases (Auta et al. 2017). Once waterborne, MPs are mistakenly ingested by marine and aquatic organisms. While the physical properties of MPs are worrying due to observed incorporation of the particles into their guts, gills, and tissues, the chemical properties are perhaps even more concerning. During plastic production, one or multiple fillers, plasticizers, pigments, antimicrobials, heat or UV stabilizers, or flame retardants are used (Rochman et al. 2019). There are several thousand distinct chemical additives used in plastics to make them flexible, resistant to heat, or durable. These additives can constitute the majority (over 70\%) of a plastic product's total weight, though on average represent about 4\% (Smith et al. 2018). Many additives incorporated into plastics are associated with well-established environmental and human health risks. More than 50\% of plastics are composed of materials known to be hazardous to environmental or human 
health (Rochman et al. 2019). These additives can become mobilized from the polymer matrix and leach into the surrounding environment. Phthalates, Bisphenol-A (BPA), polybrominated diphenyl ethers (PBDE), nonylphenols (NP), and antioxidants are the most commonly encountered plastic additives detected in the ocean (Hermabessiere et al. 2017). Some of these compounds have been widely studied and are known endocrine disruptors. BPA, for example, is a xenoestrogen which is often incorporated into plastics or used to line food and beverage containers. When ingested even at low doses, BPA interacts with important hormone receptors. Although it degrades quickly in the environment, it persists due to continual inputs from landfill leachate, environmental plastics and other sources (Flint et al. 2012). As plastics degrade, the surface area to volume ratio increases, exposing even more chemical additives and increasing their propensity to leach. Another feature of MPs is their incredible ability to sorb contaminants from the surrounding environment. Due to the hydrophobicity, chemical and molecular properties of plastics, they are extremely effective at collecting and harboring concentrations of waterborne chemical contaminants up to 1 million times more concentrated than in the surrounding waters (Mato et al. 2001). Contaminants known to be associated with microplastics include heavy metals, pesticides, dioxins and furans, flame retardants, and pharmaceutical and personal care products (Avio et al. 2015).

The transfer of plastics and plastic additives into marine organisms and up trophic levels have been demonstrated in the laboratory and found in field-collected samples (de Sá et al. 2018). After ingestion, organisms either eliminate MPs through excretion or 
pseudofeces, translocate the particles throughout the body, or retain them in one or more organs (Auta et al. 2017). Retained particles may be transferred to higher trophic levels within food webs (Farrell and Nelson 2013; Nelms et al. 2018).

The presence of potentially harmful additives and ability of contaminants to sorb to plastics consumed by animals are some of the chief concerns attributed to MP ingestion, as multiple deleterious physiological effects have been demonstrated when organisms are exposed to MPs or MP-associated chemicals (e.g., Avio et al. 2015, Hermabessiere et al. 2017, Guzzetti et al. 2018, Prokić et al. 2019). Documented impacts include neurotoxicity, oxidative stress, impaired growth and behavior, decreased reproductive output, increased immune response, decreased feeding, weight loss, energy depletion, and damage to cells and DNA (Lusher et al. 2017).

In concert, MPs, their associated additives and sorbed contaminants threaten the health of marine organisms, the environment, and potentially human seafood consumers as well (Carbery et al. 2018; Barboza et al. 2018). We now know that, as apex predators and consumers of seafood in the food chain, humans are subsequently exposed to MPs. Recent studies have estimated humans are exposed to significant amounts of MPs not only through food and beverages consumed such as seafood, beer, honey, and salt, but also from drinking water and breathing air (e.g., Catarino et al. 2018; Cox et al. 2019; Zhang et al. 2020). Plastic-associated chemicals such as BPA show troubling correlations with chronic human illnesses such as cardiovascular disease and type 2 diabetes in humans (Smith et al. 2018). While humans are likely able to clear the vast majority (>90\%) of ingested MPs from their systems (Smith et al. 2018), questions still remain 
regarding chemical transfer from MPs to the body, and the fate of plastics that are not excreted. Similar to animals, individual susceptibility and harm to human consumers from MP consumption is likely variable due to exposure route, personal traits, health, or other existing stressors. The potential cumulative effects of chronic exposure to MPs and associated chemicals in humans have not been well-documented and are therefore critical avenues of future research.

Bivalves have been used as bioindicators for evaluating the health of aquatic and marine environments since the 1960s, when mussels and clams were first used to monitor environmental pesticides and heavy metals (Farrington et al. 2016). Since then, entire long-term contaminant monitoring programs have been developed using bivalves as bioindicators. As filter feeders, bivalves are particularly vulnerable to contaminants in the estuarine and open coast environments they inhabit. Environmental MP concentrations in sediments and water often have been correlated with MP burdens in coastal bivalves (e.g., Mathalon and Hill 2014; Qu et al. 2018; Su et al. 2018). Numerous elements make bivalves ideal sentinel organisms for biomonitoring of environmental contaminants, and there are many benefits to using bivalves to monitor environmental contaminants like MPs. First, they are widely distributed around the globe in both freshwater and marine habitats. Their filter-feeding food acquisition strategy and fixed location in the environment (usually on the sea floor or in freshwater sediments) mean the pollutant levels found within represent a specific geographic locale. They can accumulate chemicals in the water up to several orders of magnitude higher than the surrounding waters, making them extremely useful for identifying and monitoring environmental 
pollutants. Because sample contamination due to air and waterborne particles are problematic in the field of MPs research, bivalves may be superior study organisms compared to other aquatic species because of their hard shell enclosures. These can effectively seal out contamination until opened in the laboratory, and also make organisms fairly robust for transportation purposes. Lastly, many species of clams, oysters and mussels are consumed by humans (often whole) and comprise key markets in aquaculture and wild fisheries. A recent study by Su et al. (2018) identified the Asian clam (an invasive species found all around the world) as an excellent bioindicator of MP pollution in freshwater ecosystems, whereby clam tissue MP concentrations and sizes were strongly related to MP concentrations and sizes in surrounding benthic sediments. This may be due to the fact that this species in particular combines filter-feeding and deposit-feeding strategies. A review by Li et al. (2019) found a positive correlation between MPs in mussel tissue and in environmental water samples worldwide.

While there are advantages to studying MPs in bivalves as indicators of environmental MP pollution, there are also disadvantages. For example, not all plastic types are necessarily bioavailable to bivalves. While it has been demonstrated that plastics less dense than seawater (such as expanded polystyrene, low density polyethylene and polypropylene) as well as those denser than seawater (polyvinyl chloride, high density polyethylene) are somewhat mixed in the water column, they are not equally distributed so monitoring of bivalve tissues may not provide a full picture of the environmental plastic material types in a particular geographic area. Some bivalves are also able to preferentially select for food particles of certain size fractions, and may 
therefore expel MPs encountered on their gills or labial palps in pseudofeces rather than ingesting them (Li et al. 2019). This preferential sorting could be problematic if attempting to extrapolate MP concentrations in bivalves to environmental concentrations.

The Pacific Northwest (PNW) coast supports diverse marine species, which have nourished, sustained and inspired local peoples since time immemorial. Present-day species targeted in commercial, tribal usual and accustomed, sport, and recreational fisheries contribute greatly to local culture, spirituality, economies, gastronomy, and food security (Olson 1936; Charles et al. 2004; Anderson and Parker 2009; Lepofsky et al. 2015). Pacific oysters and Pacific razor clams were selected as target species for investigation of MPs in my research due to their feeding mode, limited movement, importance to PNW economy and culture, and representativeness of both estuaries and open coast sandy beach environments characteristic of large swaths of the Oregon (OR) and Washington (WA) coasts. The field of MP research in marine and coastal environments is rapidly expanding and evolving, yet relatively little is known about the prevalence of MPs in many commercially-important species, particularly in North America (Baechler et al. 2020a). It is important to understand localized environmental MP prevalence, distribution and organismal uptake in order to determine the extent of MP pollution in a particular geography. Although MPs have been identified in sand samples collected from PNW beaches (Horn et al. 2020) and in water from its rivers (Valine et al. 2020), knowledge of MP burdens in OR and WA seafood species remain limited (e.g., Baechler et al. 2020b, Martinelli et al. 2020). 
This dissertation spans the broad themes of human plastic uses and behaviors, plastic prevalence in the environment, and shellfish as a vector of MPs to human seafood consumers. I apply these themes by identifying plastic uses and environmental stewardship actions that could be targeted in future education efforts, outreach endeavors and policies (Chapter 4), investigating MP pollution in PNW coastal bivalves (Chapters 2 and 3), and quantifying MP exposure by bivalve harvester-consumers (Chapter 3). The specific goals of my research are to determine:

1. Spatial, temporal and anatomical variation in MP burdens in Pacific oysters and Pacific razor clams on the OR coast (Chapter 2);

2. MP burdens in Olympic Coast, WA razor clams, and subsequent annual MP exposure by razor clam harvester-consumers (Chapter 3); and

3. Educational gains and behavioral changes of visitors at the OR Coast Aquarium after interaction with an ocean plastic exhibit (Chapter 4).

My research aims to address ocean plastic pollution research needs including: 1) prevalence of MPs found in marine species, which can ultimately help determine risk of MPs to those species; 2) human exposure to MPs through consumption of seafood items, which can ultimately inform human health risk impacts of MP exposure; and 3) prevalence of certain single-use plastic behaviors and willingness to change those behaviors, which can ultimately help reduce mismanaged plastics and plastic pollution in the ocean (Figure 2). 


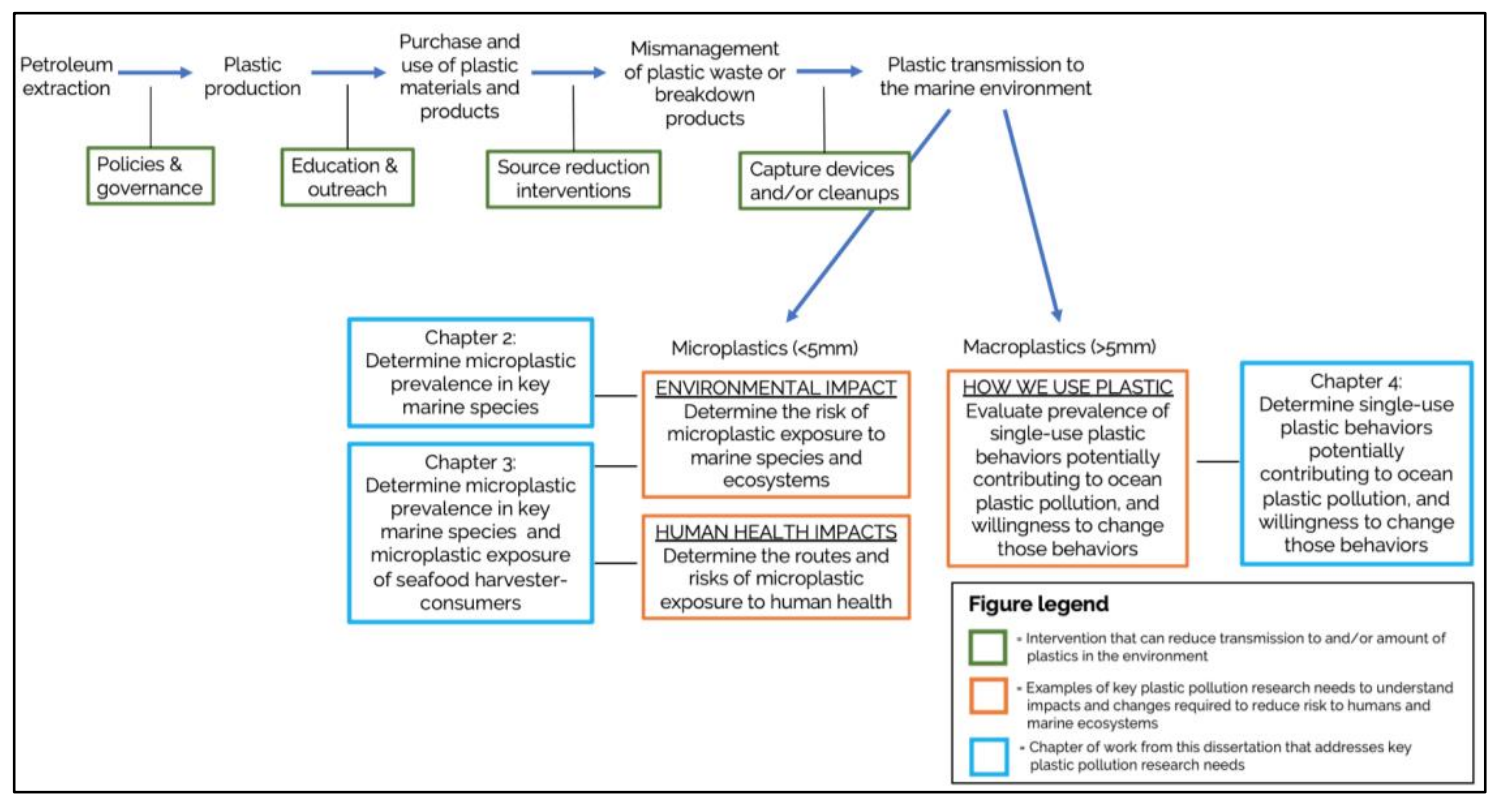

FIGURE 2. Plastic transmission to the environment: Process, interventions, examples of ocean plastic pollution research needs, and dissertation chapters that address one or more of the research needs presented.

Chapter 2 is the first study to document MPs in any OR marine species, and is also the first to determine MP burdens in Pacific razor clams anywhere in the world. It provides important coast-wide data to compare MP burden across species, seasons, and sites. Chapter 3 builds upon Chapter 2 by expanding the geographic area of known Pacific razor clam MP burdens, first confirming MP presence and spatial variability in razor clams on the Olympic Coast, WA, and then estimating annual harvester-consumer MP exposure from razor clam consumption. Chapter 4 leverages insights gained in the previous two chapters by approaching plastic pollution solutions through education and behavioral changes of aquarium visitors, as individual consumer choices, behaviors, and habits are contributors to the global plastic economy, driving demand, use and fate of those products and their packaging. Chapter 5 provides a synthesis of findings, highlighting how this work improves our understanding of MP prevalence in PNW 
seafood species and suggests the work's utility towards advancing future ocean plastic pollution education, outreach and policies aimed at reducing plastic pollution in the region.

In total, this work is critical to document prevalence of MP contaminants in PNW bivalves valued for their importance to coastal ecology and human consumers. It provides a crucial reference to measure future change of MPs in coastal organisms and allows comparisons to be drawn between the Olympic Peninsula, WA and OR coasts. It contextualizes human harvester-consumer MP exposure from one key PNW seafood species relative to other known exposure routes (e.g., inhalation of air, ingestion of drinking water). This research helps identify environmental MP characteristics, providing important clues regarding potential MP sources that could guide mitigation, engineering, and policy development. It can help inform key interventions to reduce the transmission of macro and MPs into the environment (Figure 2), and provide resource practitioners, seafood industry members, tribal members, seafood consumers, the scientific community, educators and the general public with information to reference in future management, education and outreach initiatives, and MP attenuation efforts. 


\subsection{References:}

Anderson, T. L., and D. P. Parker. 2009. Economic development lessons from and for North American Indian economies*. Australian Journal of Agricultural and Resource Economics 53: 105-127. doi:10.1111/j.1467-8489.2007.00426.x

Auta, H. S., C. U. Emenike, and S. H. Fauziah. 2017. Distribution and importance of microplastics in the marine environment: A review of the sources, fate, effects, and potential solutions. Environment International 102: 165-176. doi:10.1016/j.envint.2017.02.013

Avio, C. G., S. Gorbi, M. Milan, and others. 2015. Pollutants bioavailability and toxicological risk from microplastics to marine mussels. Environmental Pollution 198: 211-222. doi:10.1016/j.envpol.2014.12.021

Baechler, B. R., C. D. Stienbarger, D. A. Horn, J. Joseph, A. R. Taylor, E. F. Granek, and S. M. Brander. 2020a. Microplastic occurrence and effects in commercially harvested North American finfish and shellfish: Current knowledge and future directions. Limnology and Oceanography Letters 5: 113-136.

doi: $\underline{10.1002 / 1012.10122}$

Baechler, B. R., E. F. Granek, M. V. Hunter, and K. E. Conn. 2020b. Microplastic concentrations in two Oregon bivalve species: Spatial, temporal, and species variability. Limnology and Oceanography Letters 5: 54-65. doi: $\underline{10.1002 / l o l 2.10124}$

Barboza, L. G. A., Dick Vethaak, A., Lavorante, B. R. B. O., Lundebye, A.-K., and 
L. Guilhermino. 2018. Marine microplastic debris: An emerging issue for food security, food safety and human health. Marine Pollution Bulletin 5: 336-348. doi:10.1016/j.marpolbul.2018.05.047

Borrelle, S. B., J. Ringma, K. L. Law, and others. 2020. Predicted growth in plastic waste exceeds efforts to mitigate plastic pollution. Science 369: 1515-1518. doi: $\underline{10.1126 / \text { science.aba3656 }}$

Boucher, D. and D. Friot. 2017. Primary microplastics in the oceans. IUCN.

Canesi, L., C. Borghi, C. Ciacci, R. Fabbri, L. Vergani, and G. Gallo. 2007. Bisphenol-A alters gene expression and functional parameters in molluscan hepatopancreas. Molecular and Cellular Endocrinology 276: 36-44. doi:10.1016/j.mce.2007.06.002

Carbery, M., O’Connor, W., and T. Palanisami. 2018. Trophic transfer of microplastics and mixed contaminants in the marine food web and implications for human health. Environment International 115: 400-409. doi:10.1016/j.envint.2018.03.007.

Catarino, A. I., V. Macchia, W. G. Sanderson, R. C. Thompson, and T. B. Henry. 2018. Low levels of microplastics (MP) in wild mussels indicate that MP ingestion by humans is minimal compared to exposure via household fibres fallout during a meal. Environmental Pollution 237: 675-684. doi:10.1016/j.envpol.2018.02.069

Charles, B., V. Cooke, E. Grinnell, C. Morganroth III, L. M. Morganroth, M. Peterson, V. R. Hoh, A. Smith, and J. Wray. 2004. When the Tide is Out: An Ethnographic 
Study of Nearshore Use on the Northern Olympic Peninsula. Native American Traditional and Contemporary Knowledge of the Northern Olympic Peninsula. Coastal Watershed Institute and Olympic National Park. Port Angeles, Washington.

Cox, K. D., G. A. Covernton, H. L. Davies, J. F. Dower, F. Juanes, and S. E. Dudas. 2019. Human Consumption of Microplastics. Environ. Sci. Technol. 53: 7068 7074. doi:10.1021/acs.est.9b01517

Crossett, K, Ache B, Pacheco P, Haber K. 2013. National coastal population report, population trends from 1970 to 2020. NOAA State of the Coast Report Series, US Department of Commerce, Washington.

Cole, M., P. Lindeque, C. Halsband, and T. S. Galloway. 2011. Microplastics as contaminants in the marine environment: A review. Marine Pollution Bulletin 62: 2588-2597. doi:10.1016/j.marpolbul.2011.09.025

Crespy, D., M. Bozonnet, and M. Meier. 2008. 100 Years of Bakelite, the Material of a 1000 Uses. Angewandte Chemie International Edition 47: 3322-3328. doi: $\underline{10.1002 / a n i e .200704281}$

Datu, S., S. Supriadi, and A. Tahir. 2019. Microplastic in Cymodocea rotundata Seagrass Blades. International Journal of Environment, Agriculture and Biotechnology 4: 1758-1761. doi:10.22161/ijeab.46.21

de Sá, L. C., M. Oliveira, F. Ribeiro, T. L. Rocha, and M. N. Futter. 2018. Studies of the 
effects of microplastics on aquatic organisms: What do we know and where should we focus our efforts in the future? Science of The Total Environment 645 : 1029-1039. doi:10.1016/j.scitotenv.2018.07.207

Eggen, R. I. L., R. Behra, P. Burkhardt-Holm, B. I. Escher, and N. Schweigert. 2004. Challenges in ecotoxicology. Environ Sci Technol 38: 58A-64A. doi:10.1021/es040349c

Fagin, D. 2012. Toxicology: The learning curve. Nature News 490: 462. doi: $10.1038 / 490462 \mathrm{a}$

Farrell, P., and K. Nelson. 2013. Trophic level transfer of microplastic: Mytilus edulis (L.) to Carcinus maenas (L.). Environmental Pollution 177: 1-3. doi:10.1016/j.envpol.2013.01.046

Farrington, J. W., B. W. Tripp, S. Tanabe, A. Subramanian, J. L. Sericano, T. L. Wade, and A. H. Knap. 2016. Edward D. Goldberg's proposal of "the Mussel Watch": Reflections after 40years. Marine Pollution Bulletin 110: 501-510. doi:10.1016/j.marpolbul.2016.05.074

Flint, S., T. Markle, S. Thompson, and E. Wallace. 2012. Bisphenol A exposure, effects, and policy: A wildlife perspective. Journal of Environmental Management 104: 19-34. doi:10.1016/j.jenvman.2012.03.021

Gall, S. C., and R. C. Thompson. 2015. The impact of debris on marine life. Marine Pollution Bulletin 92: 170-179. doi:10.1016/j.marpolbul.2014.12.041 Gavigan, J., T. Kefela, I. Macadam-Somer, S. Suh, and R. Geyer. 2020. Synthetic 
microfiber emissions to land rival those to waterbodies and are growing. PLOS ONE 15: e0237839. doi:10.1371/journal.pone.0237839

Geyer, R., J. R. Jambeck, and K. L. Law. 2017. Production, use, and fate of all plastics ever made. Science Advances 3: e1700782. doi:10.1126/sciadv.1700782

Gu, L., and T. Ozbakkaloglu. 2016. Use of recycled plastics in concrete: A critical review. Waste Management 51: 19-42. doi:10.1016/j.wasman.2016.03.005

Guo, J.-J., X.-P. Huang, L. Xiang, and others. 2020. Source, migration and toxicology of microplastics in soil. Environment International 137: 105263. doi:10.1016/j.envint.2019.105263

Guzzetti, E., A. Sureda, S. Tejada, and C. Faggio. 2018. Microplastic in marine organism: Environmental and toxicological effects. Environmental Toxicology and Pharmacology 64: 164-171. doi:10.1016/j.etap.2018.10.009

Hermabessiere, L., A. Dehaut, I. Paul-Pont, C. Lacroix, R. Jezequel, P. Soudant, and G. Duflos. 2017. Occurrence and effects of plastic additives on marine environments and organisms: A review. Chemosphere 182: 781-793. doi: $\underline{10.1016 / j . c h e m o s p h e r e .2017 .05 .096 ~}$

Horn, D. A., E. F. Granek, and C. L. Steele. 2020. Effects of environmentally relevant concentrations of microplastic fibers on Pacific mole crab (Emerita analoga) mortality and reproduction. Limnology and Oceanography Letters 5: 74-83. doi: $\underline{10.1002 / 1012.10137}$

Horton, A. A., A. Walton, D. J. Spurgeon, E. Lahive, and C. Svendsen. 2017. 
Microplastics in freshwater and terrestrial environments: Evaluating the current understanding to identify the knowledge gaps and future research priorities.

Science of The Total Environment 586: 127-141.

doi: $\underline{10.1016 / j . s c i t o t e n v .2017 .01 .190 ~}$

Jambeck, J. R., R. Geyer, C. Wilcox, T. R. Siegler, M. Perryman, A. Andrady, R.

Narayan, and K. L. Law. 2015. Plastic waste inputs from land into the ocean.

Science 347: 768-771. doi:10.1126/science.1260352

Lau, W. W. Y., Y. Shiran, R. M. Bailey, and others. 2020. Evaluating scenarios toward zero plastic pollution. Science. doi:10.1126/science.aba9475

Lepofsky, D., N. F. Smith, N. Cardinal, and others. 2015. Ancient Shellfish Mariculture on the Northwest Coast of North America. American Antiquity 80: 236-259. doi: $10.7183 / 0002-7316.80 .2 .236$

Li, J., A. Lusher, J. M. Rotchell, and others. 2018. Using mussel as a global bioindicator of coastal microplastic pollution. Environmental Pollution.

doi:10.1016/j.envpol.2018.10.032

Lusher, A. L., N. A. Welden, P. Sobral, and M. Cole. 2017. Sampling, isolating and identifying microplastics ingested by fish and invertebrates. Analytical Methods 9: 1346-1360. doi:10.1039/C6AY02415G

Martinelli, J. C., S. Phan, C. K. Luscombe, and J. L. Padilla-Gamiño. 2020. Low incidence of microplastic contaminants in Pacific oysters (Crassostrea gigas Thunberg) from the Salish Sea, USA. Science of The Total Environment 715: 136826. doi:10.1016/j.scitotenv.2020.136826 
Mathalon, A., and P. Hill. 2014. Microplastic fibers in the intertidal ecosystem surrounding Halifax Harbor, Nova Scotia. Marine Pollution Bulletin 81: 69-79. doi:10.1016/j.marpolbul.2014.02.018

Mato, Y., T. Isobe, H. Takada, H. Kanehiro, C. Ohtake, and T. Kaminuma. 2001. Plastic Resin Pellets as a Transport Medium for Toxic Chemicals in the Marine Environment. Environ. Sci. Technol. 35: 318-324. doi:10.1021/es0010498

Napper, I. E., and R. C. Thompson. 2016. Release of synthetic microplastic plastic fibres from domestic washing machines: Effects of fabric type and washing conditions. Marine Pollution Bulletin 112: 39-45. doi:10.1016/j.marpolbul.2016.09.025

Napper, I. E., and R. C. Thompson. 2020. Plastic Debris in the Marine Environment: History and Future Challenges. Global Challenges 4: 1900081. doi: $10.1002 / g \operatorname{ch} 2.201900081$

Nelms, S. E., T. S. Galloway, B. J. Godley, D. S. Jarvis, and P. K. Lindeque. 2018. Investigating microplastic trophic transfer in marine top predators. Environmental Pollution 238: 999-1007. doi:10.1016/j.envpol.2018.02.016

Olson, R. L. 1936. Quinault Indians. University of Washington Publications in Anthropology 6: 38-39.

Ostle, C., R. C. Thompson, D. Broughton, L. Gregory, M. Wootton, and D. G. Johns. 2019. The rise in ocean plastics evidenced from a 60-year time series. Nature Communications 10: 1622. doi: $10.1038 / s 41467-019-09506-1$

Potthoff, A., K. Oelschlägel, M. Schmitt-Jansen, C. D. Rummel, and D. Kühnel. 2017. 
From the sea to the laboratory: Characterization of microplastic as prerequisite for the assessment of ecotoxicological impact: Impact Assessment of Microplastics. Integrated Environmental Assessment and Management 13: 500-504. doi: $\underline{10.1002 / \text { ieam.1902 }}$

Prokić, M. D., T. B. Radovanović, J. P. Gavrić, and C. Faggio. 2019. Ecotoxicological effects of microplastics: Examination of biomarkers, current state and future perspectives. Trends in Analytical Chemistry 111: 37-46.

doi:10.1016/j.trac.2018.12.001

Qu, X., L. Su, H. Li, M. Liang, and H. Shi. 2018. Assessing the relationship between the abundance and properties of microplastics in water and in mussels. Science of The Total Environment 621: 679-686. doi:10.1016/j.scitotenv.2017.11.284

Rochman, C. M., A. Tahir, S. L. Williams, and others. 2015. Anthropogenic debris in seafood: Plastic debris and fibers from textiles in fish and bivalves sold for human consumption. Scientific Reports 5: 14340. doi:10.1038/srep14340

Rochman, C. M., and T. Hoellein. 2020. The global odyssey of plastic pollution. Science 368: $1184-1185$. doi: $10.1126 /$ science.abc4428

Rochman, C. M., C. Brookson, J. Bikker, and others. 2019. Rethinking microplastics as a diverse contaminant suite. Environmental Toxicology and Chemistry 38: 703711. doi: $\underline{10.1002 / \text { etc. } 4371}$

Su, L., H. Cai, P. Kolandhasamy, C. Wu, C. M. Rochman, and H. Shi. 2018. Using the Asian clam as an indicator of microplastic pollution in freshwater ecosystems. Environmental Pollution 234: 347-355. doi:10.1016/j.envpol.2017.11.075 
Thompson, R. C., S. H. Swan, C. J. Moore, and F. S. vom Saal. 2009. Our plastic age. Philosophical Transactions of the Royal Society B: Biological Sciences 364: 1973-1976. doi:10.1098/rstb.2009.0054

Valine, A. E., A. E. Peterson, D. A. Horn, K. M. Scully-Engelmeyer, and E. F. Granek. 2020. Microplastic Prevalence in 4 Oregon Rivers Along a Rural to Urban Gradient Applying a Cost-Effective Validation Technique. Environmental Toxicology and Chemistry 39: 1590-1598. doi: $\underline{10.1002 / e t c .4755}$

Wright, S. L., J. Ulke, A. Font, K. L. A. Chan, and F. J. Kelly. 2020. Atmospheric microplastic deposition in an urban environment and an evaluation of transport. Environment International 136: 105411. doi:10.1016/j.envint.2019.105411

Zhang, Q., E. G. Xu, J. Li, Q. Chen, L. Ma, E. Y. Zeng, and H. Shi. 2020. A Review of Microplastics in Table salt, Drinking Water, and Air: Direct Human Exposure. Environ. Sci. Technol. doi:10.1021/acs.est.9b04535 


\section{Chapter 2: Microplastic Concentrations in Two Oregon Bivalve Species- Spatial, Temporal, and Species Variability}

Special note: This article is an invited paper to the Special Issue- Microplastics in marine freshwater organisms: Presence and potential effects. Data are available in the PDXScholar data repository at https://doi.org/10.15760/esm-data.1. Manuscript reference:

Baechler, B. R., E. F. Granek, M. V. Hunter, and K. E. Conn. 2020. Microplastic concentrations in two Oregon bivalve species: Spatial, temporal, and species variability. Limnology and Oceanography Letters 5: 54-65. doi: $10.1002 /$ lol2.10124

\subsection{Introduction:}

Microplastics, plastics 0.0001-5 mm in any linear direction (UNEP 2016), are found in nearly every environment on earth (Thompson et al. 2004). These tiny fragments, pellets, filaments, and fibers originate from both marine and land-based sources, infiltrating aquatic ecosystems worldwide through pollution, runoff, wastewater, and atmospheric deposition (Zhang 2017). Globally, the overwhelming number of singleuse and non-degradable plastic items has led to widespread microplastic pollution.

Plastics are manufactured to be durable, so degradation can take hundreds to thousands of years, posing a pervasive and severe problem for ecosystems as well as a human health concern (Cole et al. 2011; Wang et al. 2016).

While spatial distributions of microplastics in the environment are highly complex, areas with high human population, coastal recreation and tourism pressures generally yield high environmental microplastics (Barnes et al. 2009; Hantoro et al. 2019). Microplastics represent a diverse set of contaminants which encompass infinite combinations of plastic densities, sizes, shapes, surface textures, and chemical properties 
(Rochman et al. 2019). Once transmitted into the environment, microplastics are subjected to an array of dynamic hydrological, biological, and atmospheric processes including surface currents, tides, biofouling, mechanical and ultraviolet degradation, precipitation, storm events, and more. While human presence may correlate with microplastic prevalence, it is unclear what specific environmental processes best predict fate and transport of these pernicious particles (Zhang et al. 2017). Density has been thought to ultimately determine environmental fate, with denser plastics like polyvinyl chloride (PVC) and polyethylene terephthalate (PET) settling to the benthos and low density polymers such as polystyrene (PS), polypropylene (PP) and polyethylene (PE) remaining in surface waters; however, a recent review of global surface water and sediment data indicate a mixture of high and low density microplastics in water and sediment samples, attributed to influences of varied environmental and biological processes in coastal areas (Wright et al. 2013; Hantoro et al. 2019).

Rivers have been well-established as vectors of plastics into coastal and marine environments (Zhang 2017). These dynamic waterways transport between 1.2 and 2.4 million tons of plastic into global oceans each year, with up to 28.8 thousand tons transmitted annually through North and Central American rivers alone (Lebreton et al. 2017). A study investigating microplastic concentrations in surface waters from two Los Angeles, California rivers quantified an input of roughly two billion microplastic pieces into coastal waters in the span of just three days (Moore et al. 2005). Expanded to an annual output, these two rivers transport over 240 billion microplastics per year to the California coast. Stormwater runoff and wastewater treatment plant (WWTP) effluent 
also contribute significant microplastic burdens to coastal environments (e.g., Napper et al. 2016; Carr et al. 2016; Mintenig et al. 2017). Microfibers, generally broken down from laundered clothing items or from derelict fishing gear, are the most prevalent form of microplastic in the nearshore environment (Barrows et al. 2018; de Falco et al. 2019).

Organisms inhabiting coastal environments are subjected to ambient environmental conditions, including microplastic contamination that may exist in surrounding waters, substrata, or in the air. Aquatic filter- and suspension-feeding organisms can encounter microplastics in the marine or freshwater column, mistake them for food items, and ingest them (Hantoro et al. 2019). This transfer of plastics from the environment into aquatic food webs has been documented across diverse taxonomic groups, life histories, habitats, and feeding types (e.g., Cole et al. 2011; Akpan 2014; Rochman et al. 2015; Waite et al. 2018). After uptake, microplastics can adhere to organs or become incorporated into guts, gills, and tissues of organisms, decreasing energy uptake and impairing muscle function and reproduction (e.g., Von Moos et al. 2012; Sussarellu et al. 2016; Ribeiro et al. 2017; Kolandhasamy et al 2018). Microplastics may also sorb harmful contaminants that, once ingested or incorporated in tissues, are released into the organism (Teuten et al. 2007, 2009). In some studies, environmental microplastic concentrations have been directly correlated with microplastic burdens in coastal bivalves (Mathalon and Hill 2014; Li et al. 2016; Qu et al. 2018; Hantoro et al. 2019).

As filter feeders, bivalves are particularly vulnerable to contaminants in the estuarine and open coast environments they inhabit. The Pacific Northwest (PNW) region of North America supports an array of filter-feeding shellfish species, which have been 
inextricably tied to the natural history and cultural heritage of the area for millennia. Fishery and aquaculture sectors serve as important anchors of the region, with Pacific oysters and razor clams playing particularly significant roles in food security and the economy (Crossett et al. 2013). Pacific oysters (Crassostrea gigas) have been commercially farmed in the PNW since introduction of the species in the early 1900's (Glude and Chew 1982). These filter feeders consume particulates in the water column, such as plankton and other organic material, and reach commercial size $(100-150 \mathrm{~mm}$, maximum length $250 \mathrm{~mm}$ ) over 2-4 years (Pauley et al. 1988; Harris 2008). Pacific razor clams (Siliqua patula) are native to the PNW and are found on intertidal beaches. They have been harvested by first nations and tribal peoples for centuries, and in state-managed recreational and commercial fisheries since the 1950s. Consuming phytoplankton, razor clams grow rapidly in the first year attaining lengths up to $90 \mathrm{~mm}$, and a maximum length of $16 \mathrm{~cm}$ over their 6-year lifespan (Link 2000).

Microplastic concentrations in field-collected Pacific oysters have been documented worldwide facilitating comparisons between samples grown in Oregon versus other regions; however, there is no published literature on microplastic prevalence or effects in Pacific razor clams. We initiated this study to answer the question What variables predict microplastic concentrations in Oregon Pacific oysters and Pacific razor clams?.

Flowing between the U.S. states of Washington and Oregon is the Columbia river, the largest river on the North American continent with a Pacific Ocean terminus. We predicted the Columbia would be a major vector of microplastics, causing elevated 
burdens in our study species at the northernmost study sites and attenuated burdens with increased distance from the river. Coastal tourism is highest during the summer months (May to October). This creates increased use of beaches and waterways for recreation and an uptick in laundering needs, so we hypothesized that concentration of environmental microplastics in waters and coastal organisms would be higher in summer than spring. We hypothesized that gut-tissue would contain more microplastics than non-gut tissue due to retention of microplastics in the gut of bivalves observed in previous studies (e.g., Browne et al. 2008; Ward and Kach 2009; Sussarellu et al. 2016; Woods et al. 2018). Because microplastics may become lodged in gills or other organs (Woods et al. 2018), we predicted a positive relationship between organism size and microplastic burden - that larger individuals would contain more microplastics. We examined these expectations through field-collection of Pacific razor clams and purchase of Pacific oysters at 15 locations, during two seasons, taking biological measurements and investigating whole, gut-tissue, and tissue-only samples.

\subsection{Methods:}

Field sites, sample collection, processing, and microplastic enumeration

A total of 141 Pacific oysters and 142 Pacific razor clams were collected from 15 sites during low tides in spring (April 27-28) and summer (July 21-31), 2017 (Table 1). Whole oysters were purchased from growers at six grower sites during both seasons. One oyster grower was selected from each of six Pacific oyster-producing bays. In this report, oyster grower names are withheld and are coded randomly as OY1-OY6. Oyster shell 
length averaged $125.39 \mathrm{~mm}($ range $=77.67-197.66 \mathrm{~mm})$ and wet tissue weight averaged

\section{$30.97 \mathrm{~g}($ range $=8.51-101.67 \mathrm{~g}$; Chapter 2 Appendix 1).}

TABLE 1. Number of samples analyzed and average microplastic burden in Oregon Pacific oysters and Pacific razor clams by site and season, and average, minimum, and maximum lengths of microplastics identified at each site. Pacific oyster site names are randomized and coded OY1-OY6. Pacific razor clam sites are listed by latitude from north to south.

\begin{tabular}{|c|c|c|c|c|c|c|c|c|c|c|c|c|c|c|}
\hline \multirow[b]{3}{*}{ Species } & \multirow[b]{3}{*}{ Site } & \multicolumn{5}{|c|}{ SPRING } & \multicolumn{5}{|c|}{ SUMMER } & \multicolumn{3}{|c|}{ BOTH SEASONS } \\
\hline & & \multicolumn{3}{|c|}{ \# samples analyzed } & \multicolumn{2}{|c|}{ Microplastic burden } & \multicolumn{3}{|c|}{ \# samples analyzed } & \multicolumn{2}{|c|}{ Microplastic burden } & \multirow[b]{2}{*}{$\begin{array}{c}\text { Avg MP } \\
\text { length in mm } \\
(\mathrm{SE})^{\mathrm{c}}\end{array}$} & \multirow[b]{2}{*}{$\begin{array}{c}\text { Min MP } \\
\text { length } \\
(\mathrm{mm})^{\mathrm{d}} \\
\end{array}$} & \multirow[b]{2}{*}{$\begin{array}{l}\text { Max MP } \\
\text { length } \\
(\mathrm{mm})^{\mathrm{e}}\end{array}$} \\
\hline & & $\begin{array}{c}\text { Whole } \\
\text { organisms }\end{array}$ & $\begin{array}{c}\text { Gut } \\
\text { tissue }\end{array}$ & $\begin{array}{c}\text { Non- } \\
\text { gut } \\
\text { tissue }\end{array}$ & $\begin{array}{c}\text { Avg \# MP/ } \\
\text { sample (SE) }\end{array}$ & $\begin{array}{l}\text { Avg \# MP/g } \\
\text { tissue (SE) }\end{array}$ & $\begin{array}{c}\begin{array}{c}\text { Whole } \\
\text { organisms }\end{array} \\
\end{array}$ & $\begin{array}{c}\text { Gut } \\
\text { tissue }\end{array}$ & $\begin{array}{c}\text { Non- } \\
\text { gut } \\
\text { tissue }\end{array}$ & $\begin{array}{c}\text { Avg \# MP/ } \\
\text { sample (SE) }\end{array}$ & $\begin{array}{l}\text { Avg \# MP/g } \\
\text { tissue (SE) }\end{array}$ & & & \\
\hline \multirow{6}{*}{ 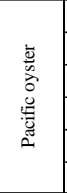 } & OY1 & 10 & 0 & 0 & $13.60(2.60)$ & $0.55(0.34)$ & 10 & 3 & 3 & $9.6(2.56)$ & $0.49(0.17)$ & $1.10(0.05)$ & 0.16 & 5.37 \\
\hline & $\mathrm{OY} 2$ & 12 & 0 & 0 & $10.33(1.92)$ & $0.35(0.29)$ & 11 & 3 & 3 & $6.81(1.58)$ & $0.21(0.05)$ & $1.32(0.06)$ & 0.18 & 5.85 \\
\hline & OY3 & 10 & 0 & 0 & $14.60(3.53)$ & $0.62(0.49)$ & 10 & 2 & 3 & $8.5(2.13)$ & $0.28(0.07)$ & $1.24(0.07)$ & 0.12 & 6.08 \\
\hline & OY4 & 10 & 0 & 0 & $17.50(3.85)$ & $0.39(0.28)$ & 10 & 3 & 3 & $5.20(1.54)$ & $0.10(0.02)$ & $1.23(0.05)$ & 0.11 & 5.42 \\
\hline & OY5 & 10 & 0 & 0 & $16.30(2.80)$ & $0.85(0.41)$ & 10 & 3 & 2 & $7.7(1.48)$ & $0.57(0.16)$ & $1.24(0.05)$ & 0.10 & 5.56 \\
\hline & OY6 & 10 & 0 & 0 & $10.80(2.01)$ & $0.31(0.16)$ & 11 & 3 & 2 & $11.00(3.03)$ & $0.50(0.17)$ & $1.31(0.07)$ & 0.15 & 5.40 \\
\hline \multirow{9}{*}{ 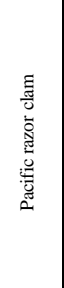 } & Clatsop Beach & 10 & 0 & 0 & $9.50(1.21)$ & $0.18(0.09)$ & 10 & 3 & 3 & $7.60(1.01)$ & $0.13(0.02)$ & $1.30(0.07)$ & 0.19 & 5.04 \\
\hline & Cannon Beach & 5 & 0 & 0 & $10.00(1.48)$ & $0.18(0.05)$ & 9 & 3 & 3 & $9.78(1.47)$ & $0.17(0.02)$ & $1.43(0.09)$ & 0.18 & 8.19 \\
\hline & Cape Meares & 10 & 0 & 0 & $8.00(2.82)$ & $0.19(0.22)$ & 7 & 3 & 3 & $7.00(2.57)$ & $0.62(0.33)$ & $1.19(0.07)$ & 0.16 & 4.27 \\
\hline & Agate Beach & 0 & 0 & 0 & N/A & N/A & 10 & 3 & 3 & $6.3(0.91)$ & $0.09(0.01)$ & $1.32(0.12)$ & 0.26 & 5.73 \\
\hline & Newport S. Beach & 13 & 0 & 0 & $9.69(1.49)$ & $0.21(0.12)$ & 10 & 3 & 3 & $9.30(0.84)$ & $0.14(0.02)$ & $1.44(0.07)$ & 0.21 & 7.04 \\
\hline & Coos Bay & 12 & 0 & 0 & $10.50(1.55)$ & $0.23(0.10)$ & 0 & 0 & 0 & N/A & N/A & $1.46(0.08)$ & 0.31 & 4.73 \\
\hline & Bastendorff Beach & 0 & 0 & 0 & N/A & N/A & 5 & 0 & 0 & $14.80(1.24)$ & $0.25(0.01)$ & $1.38(0.10)$ & 0.27 & 6.09 \\
\hline & Whiskey Creek & 0 & 0 & 0 & N/A & $\mathrm{N} / \mathrm{A}$ & 10 & 3 & 3 & $6.30(0.87)$ & $0.11(0.02)$ & $1.54(0.13)$ & 0.36 & 5.71 \\
\hline & Gold Beach & 0 & 0 & 0 & N/A & N/A & 10 & 3 & 3 & $8.70(1.47)$ & $0.12(0.02)$ & $1.29(0.09)$ & 0.26 & 4.93 \\
\hline
\end{tabular}

Notes: $\quad$ Avg. $=$ Average; $\mathrm{MP}=$ Microplastic $; \mathrm{SE}= \pm$ Standard Error; $\#=$ Number; $\mathrm{mm}=$ millimeter; ${ }^{\mathrm{a}}$ Average number of MP per sample (SE); ${ }^{\mathrm{b}}$ Average number of MP per gram of tissue (SE); ${ }^{\mathrm{c}}$ Average MP length in mm (SE); ${ }^{\mathrm{d}}$ Minimum MP length at site in $\mathrm{mm}(\mathrm{SE}) ;{ }^{\mathrm{e}}$ Minimum MP length at site in mm (SE); OY1-OY6: Oyster site (randomized). Reported values include background and processing fiber levels.

Razor clams were collected from nine sandy beach sites stretching from Clatsop

in the north, to Gold beach, near the California border, in the south (Figure 1). Of the nine clam sites, four were sampled in both spring and summer, providing a temporal snapshot of microplastic frequencies. Collection was performed in coordination with Oregon Department of Fish and Wildlife (ODFW) and Oregon Department of Agriculture (ODA), which greatly augmented collection efforts to achieve desired sample size. Clam sites were selected based on ODFW knowledge of existing clam populations, feasibility of sample collection (access, tides, clam shows), and with a goal of sampling a 
large swath of the coast. Summer clam sampling was more robust than spring because it corresponded with a coast-wide ODFW survey and coincided with lower tides than spring. Razor clam shell length averaged $113.89 \mathrm{~mm}($ range $=56.00-132.52 \mathrm{~mm})$ and wet tissue weight averaged $55.71 \mathrm{~g}$ (range= 5.84-92.11 g; Appendix A: Chapter 2).

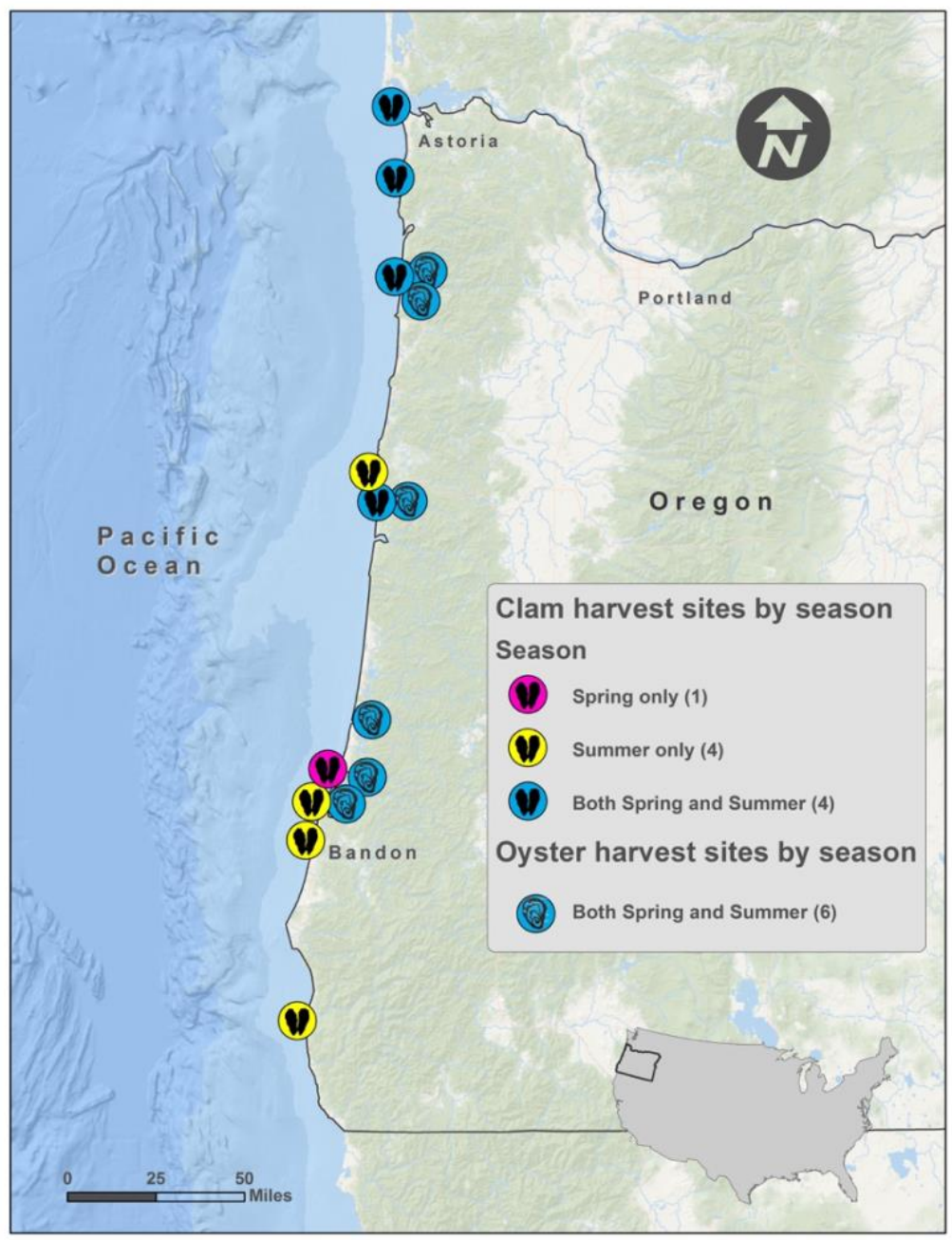

FIGURE 1. The 2017 sample collection sites along the Oregon coast delineated for Pacific oysters and Pacific razor clams [Map credit: K. Scully-Engelmeyer; Service Layer Credits: Esri, Garmin, GEBCO, NOAA, NGDC, and other contributors; Sources: Esri, USGS, NOAA].

All samples were transported on ice to the Applied Coastal Ecology laboratory at Portland State University (PSU) in Portland, Oregon, in clean 2 L glass Mason jars. Shell 
and tissue measurements were collected with a digital Mitutoyo caliper and Ohaus balance accurate to $0.01 \mathrm{~mm}$ and $0.01 \mathrm{~g}$, respectively. Bivalve shells were rinsed with DI water to remove sand, mud, and debris, were shucked into clean $120 \mathrm{~mL}$ Mason jars and frozen at $-20^{\circ} \mathrm{C}$.

Samples were thawed and digested for $24 \mathrm{~h}$ in a laminar flow fume hood using $10 \%$ potassium hydroxide $(\mathrm{KOH})$. Digestion began with the first organism from each site and season, then proceeded to the second organism from each site, until all samples were processed. Samples were poured through a $7.6 \mathrm{~cm}$ diameter, $63 \mu \mathrm{m}$ stainless steel sieve. Material retained on the sieve was rinsed into clean, labeled glass petri dishes. Petri dishes with Petristickers ${ }^{\circledR}$ affixed to the bases were placed in a drying oven at $40^{\circ} \mathrm{C}$ for $24 \mathrm{~h}$ and stored in sealed tubs prior to microscope processing. Due to high levels of organic material and sand granules remaining in clam samples after initial digestion, a second $10 \% \mathrm{KOH}$ digestion combined with hypersaline density separation $(330 \mathrm{~g} / \mathrm{L}$ Fisher Chemical Certified ACS Crystalline $\mathrm{NaCl}$ ) was utilized. Samples were analyzed under a Leica M165C stereomicroscope (10-120x magnification) connected via a Leica IC80 HD camera to a computer running Leica Application Suite X imaging software. Each suspected microplastic encountered was measured and particle type (fiber, fragment, film, foam, bead, unknown), color, and maximum length were recorded. To determine material type for microplastics, a subset of identified fibers was randomly selected using random number generation to determine: 1) sample dish, then 2) segment of each dish (segment numbers 1-16) from which to extract 26 suspected microplastics. The first fiber visually encountered in the randomly generated dish and segment was selected for 
validation. Fibers were analyzed using a Thermo Nicolet iS10 Fourier Transform Infrared Spectrometer (FTIR) equipped with an Attenuated Total Reflectance accessory at the University of New Hampshire Instrumentation Center. Spectra for each microfiber were acquired using 256 to 1024 scans depending on size and width. Automatic software comparison of microfiber spectra to a set of Thermo Nicolet Omnic ${ }^{\mathrm{TM}}$ FTIR spectral libraries was used to generate a best match.

\section{Gut/tissue separation}

During summer sampling, three individual organisms from each site (with the exceptions of Bastendorff Beach and Coos Bay) underwent a separation of digestive organs from other tissues. For Pacific oysters, gut-tissue samples included the visceral mass, esophagus, diverticular gland, midgut, and stomach. In razor clams, gut-tissue samples included the stomach, small intestine, and crystalline style. All remaining tissue was classified as non-gut tissue. Separated gut- and non-gut tissues underwent the same digestion and microscope analyses as whole organism samples.

\section{Quality control: Contamination quantification and prevention}

One hundred percent cotton clothing, cotton lab coats, and nitrile gloves were worn at all times during sample processing, digestion, and analysis procedures. All shucking implements and glassware were rinsed three times with deionized (DI) water filtered to $0.22 \mu \mathrm{m}$. To quantify procedural contamination, 11 replicates of $50 \mathrm{~mL}$ filtered DI water were frozen in $4 \mathrm{oz}$ jars and underwent the same digestion and analysis process 
as organism samples. One procedural blank per week was chemically digested alongside field samples on a randomly generated day. Additionally, three procedural blanks were collected to quantify contamination introduced by the secondary digestion and hypersaline density separation of razor clam samples.

During microscope analysis, a petri dish containing filtered DI water was placed adjacent to each sample on the microscope base and left open to the air to quantify airborne contaminants. After sample analysis, the control petri dish was analyzed for microplastics; any particles detected were assumed to be contamination and were measured and categorized.

\section{Data analysis and availability}

To identify differences between sample sites, seasons, and anatomical burdens, analysis of variance (ANOVA) and Welch's t-tests were conducted in the R statistical program (v1.2.1335) using the aov and t.test functions (R Core Team 2019). Linear regression models were used to examine relationships between biological parameters (shell length, body weight) and microplastic burdens. Microplastic concentrations are expressed as number of microplastics per sample or mean number of particles $\mathrm{g}^{-1}$ tissue (wet weight; whole organisms only). Number of microplastics per sample and number of microplastics per gram of tissue variables were $\log$ transformed $(\log x+1)$ prior to statistical analysis. The statistical cutoff (alpha) for all tests was 0.05 with Standard Error (SE) reported. Data and metadata are available in the Portland State University PDXScholar data repository. 


\subsection{Results:}

\section{Quality control}

Numerous measures were taken to minimize procedural contamination, but as with other studies (e.g., Li et al. 2015; Davidson and Dudas 2016; Qu et al. 2018; Su et al. 2018) it was not completely eliminated. Contamination in procedural controls (4.91 \pm $1.11)$, microscope blanks $(0.20 \pm 0.03)$, and, for razor clams, a secondary digestion and separation step $(1.0 \pm 0.0)$ was quantified (Appendix B: Chapter 2). From these controls and procedural blanks, total contamination in oyster and clam samples was estimated at 5.11 and 6.11 microplastics per sample, respectively. Average microplastic length detected as contamination $(n=124)$ for all sample types was $1.67 \pm 0.11 \mathrm{~mm}$, and most frequently detected colors in blanks and controls were colorless (79\%) and blue (10\%). As with multiple other studies (e.g., Li et al. 2015; Davidson and Dudas 2016; Li et al. 2016; Li et al. 2018; Qu et al 2018; Su et al. 2018; Rochman et al. 2019), we report microplastics detected in blank samples (Appendix B: Chapter 2), rather than performing a blank-subtraction on environmental results since controls were intended to provide a range of possible contamination levels introduced through laboratory procedures. As such, our reported numbers are estimated maximum possible microplastic concentrations.

\section{Microplastic occurrence in study species}

A total of 3,053 suspected microplastics were isolated from 320 whole-organism, gut-tissue, and non-gut tissue samples. Over $99 \%$ of particles were microfibers $(n=$ 3,026 ) averaging $1.34 \mathrm{~mm}$ in length (range $=0.10-8.72 \mathrm{~mm}$ ). The remaining $<1 \%$ of 
microplastics were categorized as fragments $(n=12)$, beads $(n=5)$, films $(n=5)$, foams $(n=2)$, or unknown $(n=3)$. Colorless, blue, gray, and black were the most commonly observed fiber colors at $62 \%, 21 \%, 7 \%$ and $4 \%$, respectively.

Microplastics were present in organisms at all sites during both sampling periods and across the entire geographic range sampled with some discernible patterns (Table 1, Figure 2). Mean microplastic concentrations in whole organisms was $10.95 \pm 0.77$ in Pacific oysters (range $=0-42)$ and $8.84 \pm 0.45$ in razor clams (range $=0-38)$. Mean microplastic burden per gram of tissue in whole organisms was significantly different between oysters $\left(0.35 \pm 0.04 \mathrm{~g}^{-1}\right.$ tissue $)$ and razor clams $\left(0.16 \pm 0.02 \mathrm{~g}^{-1}\right.$ tissue; $\mathrm{t}=-6.43$, df $=199 ; \mathrm{p}=<0.0001)$, but number of microplastics per whole organism was not significantly different (Table $2 ; \mathrm{t}=-1.16, \mathrm{df}=235, \mathrm{p}=0.25)$. FTIR analysis of 26 individual fibers extracted from whole organisms indicates material types of polyethylene terephthalate $(n=8)$, acrylic $(n=2)$, aramid $(n=1)$, zein $(n=1)$ and cellophane, a cellulosebased material $(n=10)$. Because cellophane exhibited a low spectral match percentage (20-67\%) relative to other materials (aramid: 68\%; all others: $80-95 \%$ ), we believe the cellophane-characterized fibers should be more broadly deemed cellulose-based material types. Additional fibers $(n=4)$ were run but no material type matches were determined, most likely due to small fiber width and concomitant low signal to noise data. 
TABLE 2. Microplastic burden of Oregon Pacific oysters and Pacific razor clams (in number of microplastics per whole individual and per gram of whole organism tissue). Significant differences are indicated in bold.

\begin{tabular}{|c|c|c|c|c|c|c|c|c|c|}
\hline \multirow[b]{2}{*}{ Species } & \multirow[b]{2}{*}{ Microplastic burden comparison } & \multicolumn{4}{|c|}{ \# Microplastics per gram of tissue } & \multicolumn{4}{|c|}{ \# Microplastics per whole organism } \\
\hline & & Test type & Test statistic & $\begin{array}{l}\text { Degrees of } \\
\text { freedom }(\mathrm{df})\end{array}$ & Significance & Test type & Test statistic & $\begin{array}{c}\text { Degrees of } \\
\text { freedom }(\mathrm{df})\end{array}$ & Significance \\
\hline \multirow{3}{*}{ 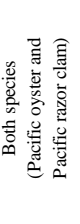 } & $\begin{array}{l}\text { Whole oyster to whole razor clam } \\
\text { (both spring and summer) }\end{array}$ & T-test & $\mathrm{T}=-6.43$ & $\mathrm{df}=199$ & $\mathrm{p}=<\mathbf{0 . 0 0 0 1}$ & T-test & $\mathrm{T}=-1.16$ & $\mathrm{df}=235$ & $\mathrm{p}=0.25$ \\
\hline & $\begin{array}{l}\text { Whole oyster to whole razor clam } \\
\text { (spring only) }\end{array}$ & T-test & $\mathrm{T}=-6.21$ & $\mathrm{df}=89$ & $\mathrm{p}=<0.0001$ & T-test & $\mathrm{T}=-2.63$ & $\mathrm{df}=103$ & $\mathrm{p}=<0.001$ \\
\hline & $\begin{array}{l}\text { Whole oyster to whole razor clam } \\
\text { (summer only) }\end{array}$ & T-test & $\mathrm{T}=-3.24$ & $\mathrm{df}=103$ & $p=0.002$ & T-test & $\mathrm{T}=-1.29$ & $\mathrm{df}=112$ & $\mathrm{p}=0.19$ \\
\hline$\overline{\mathrm{s}}$ & Gut vs tissue & \multicolumn{4}{|c|}{ N/A } & T-test & $\mathrm{T}=0.48$ & $\mathrm{df}=31$ & $\mathrm{p}=0.63$ \\
\hline$\stackrel{\mathscr{g}}{2}$ & Spring vs summer & T-test & $\mathrm{T}=2.57$ & $\mathrm{df}=121$ & $\mathrm{p}=0.01$ & T-test & $\mathrm{T}=4.41$ & $\mathrm{df}=121$ & $\mathrm{p}=<\mathbf{0 . 0 0 0 1}$ \\
\hline \multirow{2}{*}{ 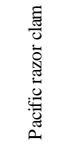 } & Gut vs tissue & \multicolumn{4}{|c|}{ N/A } & T-test & $\mathrm{T}=-0.55$ & $\mathrm{df}=39$ & $\mathrm{p}=0.59$ \\
\hline & Spring vs summer & T-test & $\mathrm{T}=-0.29$ & $\mathrm{df}=50$ & $\mathrm{p}=0.77$ & T-test & $\mathrm{T}=0.09$ & $\mathrm{df}=71$ & $\mathrm{p}=0.93$ \\
\hline
\end{tabular}

Notes: Number of microplastics per gram of tissue was not compared for gut and tissue samples, as mass was recorded for whole organism samples only. T-tests were conducted on log transformed data. To test temporal difference in Pacific oysters, data from all six sites sampled in both spring and summer were compared; for razor clams, only the four sites sampled in both seasons (Clatsop Beach, Cannon Beach, Cape Meares, Newport South Beach) were compared.

\section{Temporal differences}

Significant intra- and inter-species differences in microplastic burdens were detected during the two sampling periods (Figure 2A and B). Spring Pacific oysters contained significantly more microplastics than summer; on average, whole spring oysters contained $13.74 \pm 1.16$ microplastics $\left(0.45 \pm 0.05 \mathrm{~g}^{-1}\right.$ tissue $)$ whereas summer oysters contained $8.16 \pm 0.88\left(0.26 \pm 0.05 \mathrm{~g}^{-1}\right.$ tissue; whole organism: $\mathrm{t}=4.41 ; \mathrm{df}=121$; $\mathrm{p}<0.0001 ; \mathrm{MP} \mathrm{g}^{-1}$ tissue: $\mathrm{t}=2.57 ; \mathrm{df}=121 ; \mathrm{p}=0.01$ ). There was no significant temporal difference in microplastic burden for clams when the four sites sampled in spring and summer were compared (Clatsop Beach, Cannon Beach, Cape Meares, Newport South Beach). Spring razor clams contained $9.54 \pm 0.81$ microplastics per whole individual $\left(0.19 \pm 0.02 \mathrm{~g}^{-1}\right.$ tissue $)$ whereas summer had $8.35 \pm 0.51\left(0.14 \pm 0.04 \mathrm{~g}^{-1}\right.$ 
tissue; whole organism: $\mathrm{t}=0.09 ; \mathrm{df}=71 ; \mathrm{p}=0.93 ; \mathrm{MP} \mathrm{g}^{-1}$ tissue: $\mathrm{t}=-0.29 ; \mathrm{df}=50 ; \mathrm{p}=$ 0.77). When comparing spring oysters to spring razor clams, spring oysters contained more microplastics $\mathrm{g}^{-1}$ tissue (Table $2 ; \mathrm{t}=-6.21 ; \mathrm{df}=89 ; \mathrm{p}=<0.0001$ ) and more microplastics per whole sample (Table $2 ; \mathrm{t}=-2.63 ; \mathrm{df}=103 ; \mathrm{p}=0.01$ ). Summer oysters contained more microplastics $\mathrm{g}^{-1}$ tissue than summer razor clams $($ Table $2 ; \mathrm{t}=-3.24 ; \mathrm{df}=$ $103 ; \mathrm{p}=0.002)$, but not more plastics per whole organism (Table $2 ; \mathrm{t}=-1.29 ; \mathrm{df}=112 ; \mathrm{p}$ $=0.19$ ). 


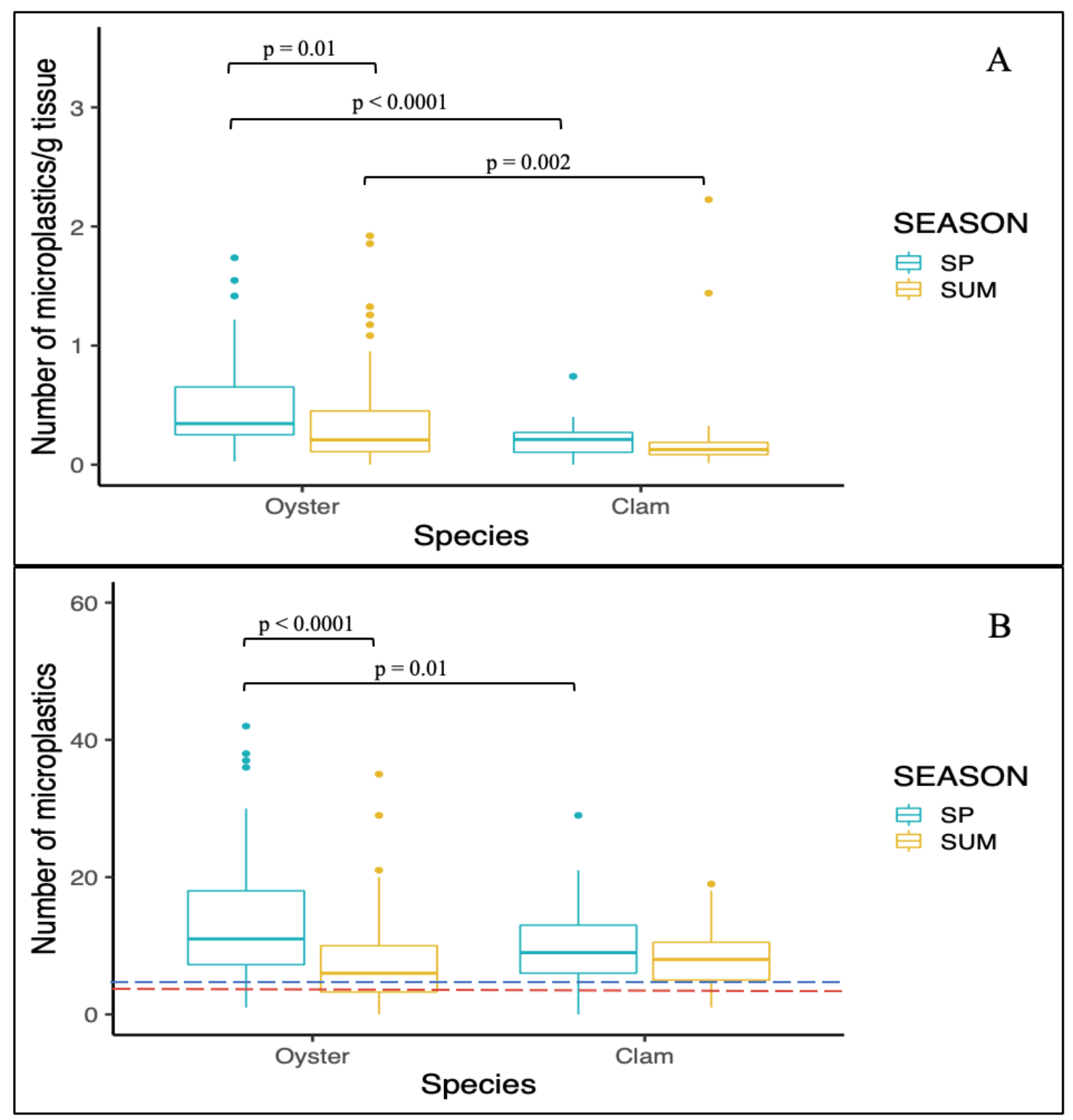




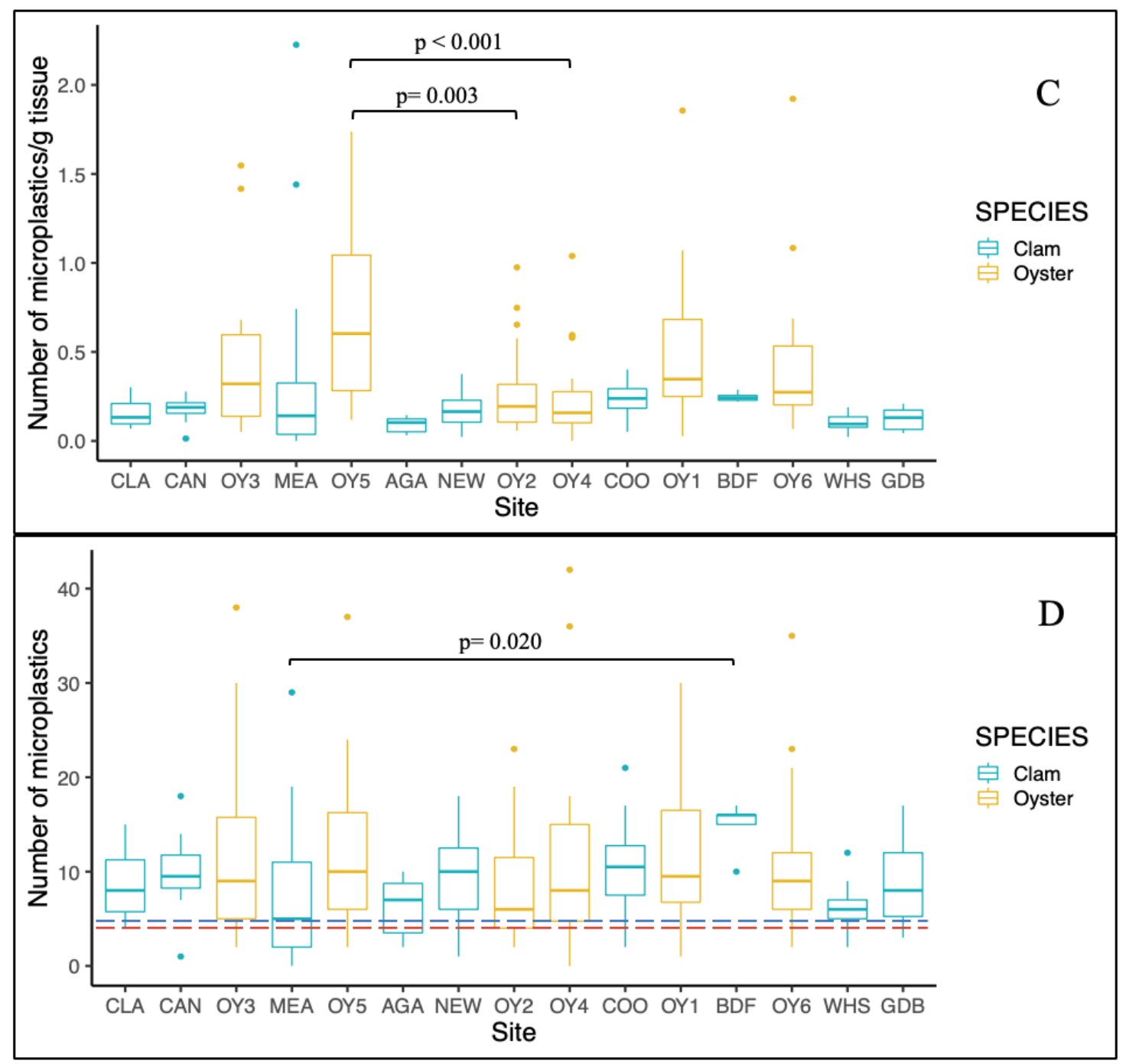

FIGURE 2. (A-B): Number of microplastics by season ( $\mathrm{SP}=$ spring (teal) and $\mathrm{SUM}=$ summer (gold)) and species for Oregon Pacific oysters and Pacific razor clams: A) per gram of whole-organism tissue, and B) per whole organism. Welch's T-tests were run to determine seasonal intra- and inter- species differences in log transformed values. P-values show significant differences in microplastic burdens for seasons and/or species pairs indicated. $(C-D)$ : Number of microplastics in Oregon Pacific oysters (gold) and razor clams (teal): C) per gram of whole-organism tissue, and D) per whole organism. Dashed blue line indicates average contamination level for razor clams (6.11 microplastics per sample); dashed red line indicates contamination level for oysters (5.11 microplastics per sample). ANOVA and post-hoc Tukey tests were run for each species to determine significance. P-values show significant differences in microplastic burdens for site pairs indicated. Data are combined for both spring and summer sampling periods. Reported values include background and processing fiber levels. Sites are arranged north to south by latitude. OY1OY6: Randomized oyster sites; $\mathrm{CLA}=$ Clatsop Beach; $\mathrm{CAN}=$ Cannon Beach; MEA= Cape Meares; $\mathrm{AGA}=$ Agate Beach; NEW= Newport; $\mathrm{COO}=$ Coos Bay; $\mathrm{BDF}=$ Bastendorff Beach; WHS= Whiskey Run; $\mathrm{GDB}=$ Gold Beach. Reported values include background and processing fiber levels. 
Site differences

ANOVA and post-hoc Tukey tests revealed site-specific differences in microplastic burdens per gram of whole oyster tissue from two site pairings (Figure $2 \mathrm{C} ; \mathrm{p}$ $<0.001$ and $\mathrm{p}=0.003)$. Site-specific differences in number of microplastics per individual were not detected in oysters (Figure 2D; $F=0.56$; $\mathrm{df}=5 ; \mathrm{p}=0.73$ ). For razor clams, sitespecific differences in microplastics per gram of tissue were not detected (Figure 2C), but were for microplastics per individual in one site pairing (Figure 2D; F = 2.54; $\mathrm{df}=8 ; \mathrm{p}=$ $0.020)$.

Anatomical burdens

Microplastics were detected in whole organism, gut-tissue, and non-gut tissue samples in both species from all sites sampled in the summer, except at Bastendorff Beach where sample size precluded separate gut and tissue analyses, and Coos Bay, which was not sampled in summer (Figure 3). Microplastic burden (number of plastics per sample) did not differ between gut-tissue and non-gut tissue in either species (Table 2); Oysters: $\mathrm{t}=0.48 ; \mathrm{df}=31 ; \mathrm{p}=0.63$; Clams: $\mathrm{t}=-0.55 ; \mathrm{df}=39 ; \mathrm{p}=0.59)$. In oysters, average microplastic burden was $10.69 \pm 2.01$ in gut-tissue and $9.41 \pm 1.30$ in non-gut tissue samples. In razor clams, average microplastic burden was $6.57 \pm 1.02$ in gut-tissue and $7.43 \pm 1.64$ in non-gut tissue samples. 


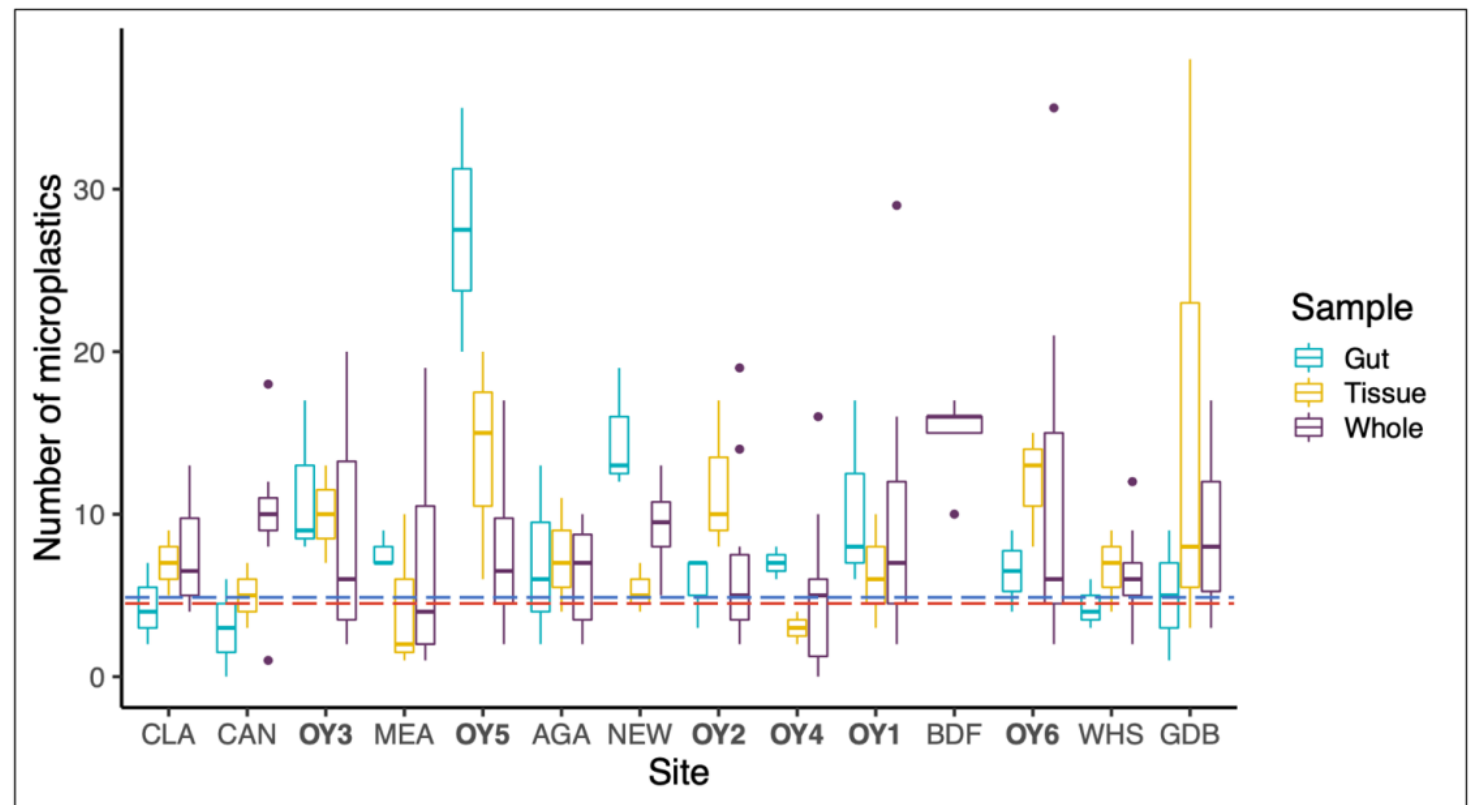

FIGURE 3. Comparison of sample types for summer-collected Pacific oysters (site names bolded) and Pacific razor clams. Reported values include background and processing fiber levels. Gut= gut-tissue, Tissue $=$ non-gut tissue, Whole $=$ whole organism. Dashed blue line indicates average contamination level for razor clams (6.11 microplastics per sample); dashed red line indicates contamination level for oysters (5.11 microplastics per sample). Sites are arranged north to south by latitude. OY1-OY6: Randomized oyster sites; CLA= Clatsop Beach; $\mathrm{CAN}=$ Cannon Beach; MEA= Cape Meares; AGA= Agate Beach; $\mathrm{NEW}=$ Newport; BDF= Bastendorff Beach; WHS = Whiskey Run; GDB= Gold Beach.

Shell length, body weight, and microplastic burden

Regression analyses revealed shell length (in $\mathrm{mm}$ ) was not significantly correlated with number of microplastics per whole organism in oysters $\left(F=0.081, \mathrm{df}=122, \mathrm{R}^{2}=-\right.$ $0.008, \mathrm{p}=0.777)$ or razor clams $\left(\mathrm{F}=0.421, \mathrm{df}=118, \mathrm{R}^{2}=-0.005, \mathrm{p}=0.518\right)$. Similarly, body weight (in g) was not significantly correlated with number of microplastics per whole organism in oysters $\left(\mathrm{F}=0.430, \mathrm{df}=122, \mathrm{R}^{2}=-0.005, \mathrm{p}=0.514\right)$ or razor clams $(\mathrm{F}=$ 1.355, df=118, $\left.\mathrm{R}^{2}=0.003, \mathrm{p}=0.247\right)$. 


\subsection{Discussion:}

Microplastics were present in both Pacific oysters and Pacific razor clams collected from all 15 Oregon coast sample sites in both spring and summer 2017. All whole organisms $(\mathrm{n}=245)$ except one oyster and one razor clam contained at least one plastic particle. Microplastic concentrations varied significantly by season in oysters but not razor clams. Limited site-specific differences in microplastic burden were detected for oysters but not razor clams. Contamination in our samples combined with relatively small sample size may have influenced the lack of site differences during statistical analyses. No anatomical microplastic burden differences were detected between gut- and non-gut tissues in either species, and organism size did not correlate with microplastic burden. Both razor clams and Pacific oysters are low trophic level species important to both the ecology of Oregon's nearshore and estuarine environments and humans who culture or consume them. To our knowledge, this is the first study to document microplastics in Pacific razor clams and Pacific oysters harvested in Oregon. Various edible oyster and clam species have been found to contain microplastics elsewhere in the world, including Asia, British Columbia, and Europe (e.g., Mathalon and Hill 2014; Davidson and Dudas 2016; Van Cauwenberghe and Janssen 2014; Li et al. 2015; Su et al. 2018). In this study, the average number of microplastics found in Pacific oysters and razor clams $\left(0.35 \pm 0.04 \mathrm{~g}^{-1}\right.$ tissue and $0.16 \pm 0.02 \mathrm{~g}^{-1}$ tissue $)$ was low compared to average concentrations in Pacific oysters in France, China, and Tunisia of 0.47, 0.62 and 1.5 items $\mathrm{g}^{-1}$ tissue (Van Cauwenberghe and Janssen 2014; Teng et al. 2019; Abidli et al. 2019), mussels from China of 2.2-2.4 items $\mathrm{g}^{-1}$ tissue ( $\mathrm{Li}$ et al. 2016; Li et al 2015), and 
manila clams from British Columbia, Canada of 0.9-1.7 items $\mathrm{g}^{-1}$ tissue (Davidson and Dudas 2016). Concentrations from this study are in the range of those found in blue

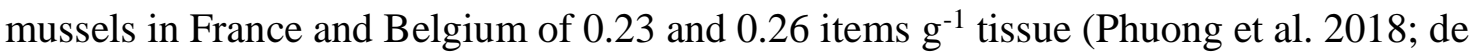
Witte et al. 2014), and are the low end of concentrations found in manila clams in China of 0.3-4.9 items $\mathrm{g}^{-1}$ tissue (Su et al. 2018). These patterns may be result from the relatively small human population residing on the Oregon coast.

As this is the first study to document prevalence of microplastics in Pacific razor clams (S. patula), no comparisons are possible between our Oregon samples and other areas. Due to the importance of the recreational, commercial, and tribal razor clam fisheries in the broader PNW, microplastic burden data from other states and territories in the region should be collected to help elucidate possible larger-scale patterns in prevalence.

In estuarine-grown oysters, collection season appears to influence microplastic burden more than harvest location. Additional research is needed to identify the environmental or anthropogenic factors driving higher microplastic burden in oysters in the spring. Seasonal microplastic differences in oysters but not razor clams may be a function of habitat. Oysters inhabit estuarine environments, which receive land-based stormwater and wastewater inputs before ocean-facing beaches do; therefore, pulse inputs of microplastics may be more concentrated in estuaries than along the open coast. Precipitation was at least $100 \%$ higher than normal in all coastal counties and up to three orders of magnitude higher in some coastal areas in April 2017 compared to July 2017, which was characterized by at least $50 \%$ lower than normal precipitation in all coastal 
counties (NOAA Northwest River Forecast Center 2017). Therefore, seasonal differences in oysters may be driven, in part, by seasonal precipitation and resultant stormwater fluctuations. Another possibility is that the nature of clothing laundered in the spring cold weather clothes, possibly dominated by insulating synthetic materials - may increase microfiber levels in WWTP outputs when compared to clothing items laundered in the summer. Other potential seasonal factors include temperature-associated influences on metabolic and feeding rates, which may be depressed during colder seasons, and life history events like spawning and associated physiological responses. Differences in aquaculture techniques, such as degree of plastic use by oyster growers, may contribute to variation in oyster microplastic burdens between sites and over time; however, growerspecific culture techniques were not assessed in this study and previous studies in the Pacific Northwest have failed to find a connection between aquaculture and microplastic burden in cultured Pacific oysters and manila clams when compared to wild-grown organisms (Davidson and Dudas 2016; Covernton et al. 2019). Temporal differences identified in this study indicate oysters may be able to clear microplastics from their system over time, as previously shown in laboratory studies where manila clams and blue mussels (29-40mm in length) eliminated microplastics in feces and pseudofeces when depurated in clean water, with up to $60 \%$ of particles cleared from the body in as little as $9 \mathrm{~h}$ (Xu et al 2017; Woods et al. 2018). However, elimination of microplastics was not detected in blue mussels $(50-55 \mathrm{~mm}$ length) during a depuration period of two hours (Rist et al. 2018). While, in these examples, depuration was studied in bivalves smaller than our study organisms (Appendix A: Chapter 2), the results are promising and warrant 
further research. Depuration of oysters or razor clams in freshwater for some period of time prior to sale may be a fruitful avenue for reducing anthropogenic debris in those seafood items.

Visual microscopy is routinely used in microplastics research due to the relatively wide availability of microscopes, but it likely introduces error to microplastic counts. Recent studies indicate visual microscopy can either overestimate or underestimate microplastic counts depending on particle shape and size (Song et al. 2015); thus, additional validation methods should be used to supplement visual analysis methods. In this study, FTIR techniques were used to ground truth material composition of a randomly-selected subset ( $\mathrm{n}=26$ ) of the 2,428 microfibers found in whole samples, which were subsequently identified as polyethylene terephthalate $(\mathrm{n}=8)$, acrylic $(\mathrm{n}=2)$, aramid $(\mathrm{n}=1)$, zein $(\mathrm{n}=1)$ and cellophane, a cellulose-based material $(\mathrm{n}=10)$. Our low percentage of validated fibers was due to funding limitations and lack of on-site equipment. Polyethyelene terephthalate, acrylic, and aramid fibers have been previously found in organisms (e.g., Li et al. 2015; Nelms et al. 2018; Li et al. 2018), and zein (a corn-based protein used in bioplastics) has been isolated from wastewater treatment plant (WWTP) sludge (Bayo et al. 2016). Fibrous cellophane, the putative material type comprising the largest proportion of successfully validated fibers $(n=10)$, is made of heavily modified cellulose but has previously been categorized as a microplastic in studies that identified cellophane fibers in bivalves (Li et al. 2016; Ding et al. 2018; Li et al. 2018). Due to low spectral match percentage of cellophane (20-67\%) relative to other materials matched to 
known spectra (aramid: 68\%; all others: 80-95\%), we believe the cellophanecharacterized fibers should be more broadly deemed cellulose-based material types.

Our lower size limit of detection for microplastics was $0.063 \mathrm{~mm}$ owing to the mesh size of the sieve used, so microplastics smaller than $0.063 \mathrm{~mm}$ in length may be underestimated using these methods. Microplastics between $0.10-8.72 \mathrm{~mm}$ in length were included in this report, as they are of equal interest as microplastics fitting the conventional $0.0001-5 \mathrm{~mm}$ definition. Future studies on these and other bivalve species should include methods capable of detecting both micro and nanoplastics $\left(1 \times 10^{-6}-1 \times 10^{-4}\right.$ $\mathrm{mm}$ ), as particles between $1 \times 10^{-4}$ and $2 \times 10^{-2} \mathrm{~mm}$ can penetrate internal organ barriers (Lusher et al. 2017).

In this study we found that all whole organisms $(n=245)$ except one oyster and one razor clam contained at least one microplastic, though we acknowledge that some of these detections may have been influenced by contamination in the laboratory. For this reason, we ran several types of blank and control samples during processing and analysis to quantify it. Microfiber contamination may have been due to presence in $\mathrm{KOH}$ pellets used for chemical digestion, fibers shed from clothing, laboratory furniture (chairs), or airborne particles. Average contamination represented $46.7 \%$ of the average microplastic burdens reported for whole oysters, and $69.1 \%$ of average microplastic reported for whole clams. While contamination in this study appears high, it is consistent with similar studies that report between 51 and $94 \%$ of detected microplastic values in mussels and clams may represent contamination (Mathalon and Hill 2014; Davidson and Dudas 
2016). Contamination documented in this and other microplastic investigations highlights the ubiquity of anthropogenic microfibers in the environment.

The degree to which microplastics pose a threat to coastal marine ecology or bivalve predators (including humans), is still unclear; however, this study provides valuable insights about spatial and temporal variability in microplastic prevalence in important commercial species, sheds light on potential ecological concerns related to microplastic contamination, and serves as a baseline from which future microplastic studies in the region can draw comparisons. Future research on extent of microplastic encounter rates, consumption, and effects on biological endpoints are critical to better understand potential population-level effects on bivalves and marine organisms around the world. 


\subsection{Acknowledgements:}

Many thanks to Dr. E. Foster and Dr. M. Nielsen-Pincus for procedural \& analytical guidance; to A. Marquardt, M. Rogers, Dr. S. Rumrill of ODFW and N. Jensen of ODA for assistance with razor clam sample collection and coordination; to Dr. P. Wilkinson at the University of New Hampshire for her FTIR work; to K. ScullyEngelmeyer for mapping assistance; to J. Dorsheimer of Thermo Scientific for spectral matching assistance; to Dr. A. Strecker for use of her microscope; to A. Bolm, S. Holland, C. Orr, J. Adelsheim, M. Rollins, C. Homer, M. Jauregui, H. Smiley, D. Van Leuven and C. Tenorio for assistance in the lab and field; and to the Applied Coastal Ecology lab for valuable input and support. Thank you to the two anonymous peer reviewers and editorial team for providing comments that greatly improved the manuscript. Funding for this project was provided by Oregon Sea Grant (Award \# NA14OAR4170064), the Edward D. \& Olive C. Bushby Scholarship, the OR American Fisheries Society, and the Portland State University Institute for Sustainable Solutions. 


\subsection{References:}

Abidli, S., Y. Lahbib, and N. Trigui El Menif. 2019. Microplastics in commercial molluscs from the lagoon of Bizerte (Northern Tunisia). Marine Pollution Bulletin 142: 243-252. doi:10.1016/j.marpolbul.2019.03.048

Akpan, N. 2014. Earth \& Environment: Microplastics lodge in crab gills, guts: Creatures absorb particles through food and via respiration. Science News 186: 9-9. doi: $\underline{10.1002 / \operatorname{scin} .2014 .5591860307}$

Barnes, David K. A., Galgani Francois, Thompson Richard C., and Barlaz Morton. 2009. Accumulation and fragmentation of plastic debris in global environments. Philosophical Transactions of the Royal Society B: Biological Sciences 364: 1985-1998. doi:10.1098/rstb.2008.0205

Barrows, A. P. W., S. E. Cathey, and C. W. Petersen. 2018. Marine environment microfiber contamination: Global patterns and the diversity of microparticle origins. Environmental Pollution 237: 275-284. doi:10.1016/j.envpol.2018.02.062

Bayo, J., S. Olmos, J. López-Castellanos, and A. Alcolea. 2016. Microplastics and microfibers in the sludge of a municipal wastewater treatment plant. International Journal of Sustainable Development and Planning 11: 812-821. doi:10.2495/SDP-V11-N5-812-821

Browne, M. A., A. Dissanayake, T. S. Galloway, D. M. Lowe, and R. C. Thompson. 2008. Ingested Microscopic Plastic Translocates to the Circulatory System of the Mussel, Mytilus edulis (L.). Environ. Sci. Technol. 42: 5026-5031. doi: $10.1021 /$ es $800249 \mathrm{a}$ 
Carr, S. A., J. Liu, and A. G. Tesoro. 2016. Transport and fate of microplastic particles in wastewater treatment plants. Water Research 91: 174-182. doi: 10.1016/j.watres.2016.01.002

Covernton G. A., B. Collicutt, H. J. Gurney-Smith, C. M. Pearce, J. F. Dower, P.S. Ross, and S. E. Dudas. 2019. Microplastics in bivalves and their habitat in relation to shellfish aquaculture proximity in coastal British Columbia, Canada. Aquacult Environ Interact 11: 357-374. doi: $\underline{10.3354 / \mathrm{aei00316}}$

Crossett, K, Ache B, Pacheco P, Haber K. 2013. National coastal population report, population trends from 1970 to 2020 . NOAA State of the Coast Report Series, US Department of Commerce, Washington.

Cole, M., P. Lindeque, C. Halsband, and T. S. Galloway. 2011. Microplastics as contaminants in the marine environment: A review. Marine Pollution Bulletin 62: 2588-2597. doi:10.1016/j.marpolbul.2011.09.025

Davidson, K., and S. E. Dudas. 2016. Microplastic Ingestion by Wild and Cultured Manila Clams (Venerupis philippinarum) from Baynes Sound, British Columbia. Arch. Environ. Contam. Toxicol. 71: 147-156. doi:10.1007/s00244-016-0286-4

De Witte, B., L. Devriese, K. Bekaert, S. Hoffman, G. Vandermeersch, K. Cooreman, and J. Robbens. 2014. Quality assessment of the blue mussel (Mytilus edulis): Comparison between commercial and wild types. Marine Pollution Bulletin $\mathbf{8 5}$ : 146-155. doi:10.1016/j.marpolbul.2014.06.006

Ding, J.-F., J.-X. Li, C.-J. Sun, C.-F. He, F.-H. Jiang, F.-L. Gao, and L. Zheng. 2018. 
Separation and Identification of Microplastics in Digestive System of Bivalves. Chinese Journal of Analytical Chemistry 46: 690-697. doi:10.1016/S1872-

\section{$\underline{2040(18) 61086-2}$}

Falco, F. D., E. D. Pace, M. Cocca, and M. Avella. 2019. The contribution of washing processes of synthetic clothes to microplastic pollution. Sci Rep 9: 1-11. doi:10.1038/s41598-019-43023-X

Glude, J.B. and K. K. Chew. 1982. Shellfish Aquaculture in the Pacific Northwest. University of Alaska, Anchorage. Alaska Sea Grant Report 82-2:291-304 In Pauley, G. B., B. Van Der Raay, and D. Troutt. 1988. Species Profiles: Life Histories and Environmental Requirements of Coastal Fishes and Invertebrates (Pacific Northwest), Pacific Oyster. Washington Cooperative Fishery Research Unit Seattle.

Hantoro, I., A. J. Löhr, F. G. A. J. V. Belleghem, B. Widianarko, and A. M. J. Ragas. 2019. Microplastics in coastal areas and seafood: implications for food safety. Food Additives \& Contaminants: Part A 36: 674-711. doi: $\underline{10.1080 / 19440049.2019 .1585581}$

Harris, J. 2008. Pacific oyster, Crassostrea gigas (Thunberg, 1793). Aquatic Invasive Species Profile. Aquatic Invasion Ecology.

Horn, D., E.F. Granek, and C.L. Steele. in prep. (this issue) Impacts of EnvironmentallyRelevant Concentrations of Polypropylene Rope on Pacific Mole Crab (Emerita analoga) Development and Lifespan. Limnol. Oceanogr.: Letters.

Jambeck, J. R., R. Geyer, C. Wilcox, T. R. Siegler, M. Perryman, A. Andrady, R. 
Narayan, and K. L. Law. 2015. Plastic waste inputs from land into the ocean. Science 347: 768-771. doi:10.1126/science.1260352

Kolandhasamy, P., L. Su, J. Li, X. Qu, K. Jabeen, and H. Shi. 2018. Adherence of microplastics to soft tissue of mussels: A novel way to uptake microplastics beyond ingestion. Science of The Total Environment 610-611: 635-640. doi: $\underline{10.1016 / j . s c i t o t e n v .2017 .08 .053 ~}$

Lebreton, L. C. M., J. van der Zwet, J.-W. Damsteeg, B. Slat, A. Andrady, and J. Reisser. 2017. River plastic emissions to the world's oceans. Nature Communications 8: 15611. doi: $10.1038 /$ ncomms 15611

Li, H.-X., L.-S. Ma, L. Lin, and others. 2018. Microplastics in oysters Saccostrea cucullata along the Pearl River Estuary, China. Environmental Pollution 236: 619-625. doi:10.1016/j.envpol.2018.01.083

Li, J., D. Yang, L. Li, K. Jabeen, and H. Shi. 2015. Microplastics in commercial bivalves from China. Environmental Pollution 207: 190-195.

doi:10.1016/j.envpol.2015.09.018

Li, J., X. Qu, L. Su, W. Zhang, D. Yang, P. Kolandhasamy, D. Li, and H. Shi. 2016. Microplastics in mussels along the coastal waters of China. Environmental Pollution 214: 177-184. doi:10.1016/j.envpol.2016.04.012

Li, J., C. Green, A. Reynolds, H. Shi, and J. M. Rotchell. 2018. Microplastics in mussels sampled from coastal waters and supermarkets in the United Kingdom. Environmental Pollution 241: 35-44. doi:10.1016/j.envpol.2018.05.038

Link, T. 2000. History and status of Oregon's Pacific razor clam resources. Information 
Reports 2000-06, Oregon Department of Fish and Wildlife, Marine Resources Program, Astoria, OR: 1-25.

Lusher, A., P. Hollman, and J. Mendoza-Hill. 2017. Microplastics in fisheries and aquaculture: Status of knowledge on their occurrence and implications for aquatic organisms and food safety. FAO Fisheries and Aquaculture Technical Paper; Rome.

Mathalon, A., and P. Hill. 2014. Microplastic fibers in the intertidal ecosystem surrounding Halifax Harbor, Nova Scotia. Marine Pollution Bulletin 81: 69-79. doi:10.1016/j.marpolbul.2014.02.018

Mintenig, S. M., I. Int-Veen, M. G. J. Löder, S. Primpke, and G. Gerdts. 2017. Identification of microplastic in effluents of waste water treatment plants using focal plane array-based micro-Fourier-transform infrared imaging. Water Research 108: 365-372. doi:10.1016/j.watres.2016.11.015

Moore, C., G. Lattin, and A. Zellers. 2005. A Brief Analysis of Organic Pollutants Sorbed to Pre and Post Production Plastic Particles from the Los Angeles and San Gabriel River Watersheds. Algalita Marine Research Foundation.

von Moos, N., P. Burkhardt-Holm, and A. Köhler. 2012. Uptake and Effects of Microplastics on Cells and Tissue of the Blue Mussel Mytilus edulis L. after an Experimental Exposure. Environ. Sci. Technol. 46: 11327-11335. doi: $10.1021 / \mathrm{es} 302332 \mathrm{~W}$

Napper, I. E., and R. C. Thompson. 2016. Release of synthetic microplastic plastic fibres 
from domestic washing machines: Effects of fabric type and washing conditions. Marine Pollution Bulletin 112: 39-45. doi:10.1016/j.marpolbul.2016.09.025

Nelms, S. E., T. S. Galloway, B. J. Godley, D. S. Jarvis, and P. K. Lindeque. 2018. Investigating microplastic trophic transfer in marine top predators. Environmental Pollution 238: 999-1007. doi:10.1016/j.envpol.2018.02.016

Pauley, G. B., B. Van Der Raay, and D. Troutt. 1988. Species Profiles: Life Histories and Environmental Requirements of Coastal Fishes and Invertebrates (Pacific Northwest), Pacific Oyster. Washington Cooperative Fishery Research Unit Seattle.

PCSGA, 2006. Shellfish Production on the West Coast. http://www.pcsga/pub/uploads/ production.pdf In Dumbauld, B. R., J. L. Ruesink, and S. S. Rumrill. 2009. The ecological role of bivalve shellfish aquaculture in the estuarine environment: A review with application to oyster and clam culture in West Coast (USA) estuaries. Aquaculture 290: 196-223. doi:10.1016/j.aquaculture.2009.02.033

Phuong, N. N., L. Poirier, Q. T. Pham, F. Lagarde, and A. Zalouk-Vergnoux. 2018. Factors influencing the microplastic contamination of bivalves from the French Atlantic coast: Location, season and/or mode of life? Marine Pollution Bulletin 129: 664-674. doi:10.1016/j.marpolbul.2017.10.054

Qu, X., L. Su, H. Li, M. Liang, and H. Shi. 2018. Assessing the relationship between the abundance and properties of microplastics in water and in mussels. Science of The Total Environment 621: 679-686. doi:10.1016/j.scitotenv.2017.11.284

R Core Team. 2019. R: A language and environment for statistical computing. R 
Foundation for Statistical Computing, Vienna, Austria. URL https://www.Rproject.org/.

Ribeiro, F., A. R. Garcia, B. P. Pereira, M. Fonseca, N. C. Mestre, T. G. Fonseca, L. M. Ilharco, and M. J. Bebianno. 2017. Microplastics effects in Scrobicularia plana. Marine Pollution Bulletin 122: 379-391. doi:10.1016/j.marpolbul.2017.06.078

Rist, S., I. M. Steensgaard, O. Guven, T. G. Nielsen, L. H. Jensen, L. F. Møller, and N. B. Hartmann. 2018. The fate of microplastics during uptake and depuration phases in a blue mussel exposure system. Environmental Toxicology and Chemistry 38: 99-105. doi:10.1002/etc.4285

Rochman, C. M., A. Tahir, S. L. Williams, and others. 2015. Anthropogenic debris in seafood: Plastic debris and fibers from textiles in fish and bivalves sold for human consumption. Scientific Reports 5: 14340. doi:10.1038/srep14340

Rochman, C. M., C. Brookson, J. Bikker, and others. 2019. Rethinking microplastics as a diverse contaminant suite. Environmental Toxicology and Chemistry 38: 703711. doi: $10.1002 /$ etc. 4371

Song, Y. K., S. H. Hong, M. Jang, G. M. Han, M. Rani, J. Lee, and W. J. Shim. 2015. A comparison of microscopic and spectroscopic identification methods for analysis of microplastics in environmental samples. Marine Pollution Bulletin 93: 202209. doi:10.1016/j.marpolbul.2015.01.015

Su, L., H. Cai, P. Kolandhasamy, C. Wu, C. M. Rochman, and H. Shi. 2018. Using the Asian clam as an indicator of microplastic pollution in freshwater ecosystems. Environmental Pollution 234: 347-355. doi:10.1016/j.envpol.2017.11.075 
Sussarellu, R., M. Suquet, Y. Thomas, and others. 2016. Oyster reproduction is affected by exposure to polystyrene microplastics. PNAS 113: 2430-2435. doi:10.1073/pnas.1519019113

Teng, J., Q. Wang, W. Ran, D. Wu, Y. Liu, S. Sun, H. Liu, R. Cao and J. Zhao. 2019. Microplastic in cultured oysters from different coastal areas of China. Science of The Total Environment 653: 1282-1292. doi:10.1016/j.scitotenv.2018.11.057

Teuten, E. L., S. J. Rowland, T. S. Galloway, and R. C. Thompson. 2007. Potential for Plastics to Transport Hydrophobic Contaminants. Environ. Sci. Technol. 41: 7759-7764. doi: $\underline{10.1021 / \mathrm{es} 071737 \mathrm{~s}}$

Teuten E. L., Saquing J. M., Knappe Detlef R. U., and others. 2009. Transport and release of chemicals from plastics to the environment and to wildlife. Philosophical Transactions of the Royal Society B: Biological Sciences 364: 2027-2045. doi:10.1098/rstb.2008.0284

Thompson, R. C., Y. Olsen, R. P. Mitchell, A. Davis, S. J. Rowland, A. W. G. John, D. McGonigle, and A. E. Russell. 2004. Lost at Sea: Where Is All the Plastic?

Science 304: 838-838. doi:10.1126/science.1094559

UNEP. 2016. Marine Plastic Debris and Microplastic Technical Report, United Nations Environmental Programme, Nairobi.

Van Cauwenberghe, L., and C. R. Janssen. 2014. Microplastics in bivalves cultured for human consumption. Environmental Pollution 193: 65-70. doi:10.1016/j.envpol.2014.06.010

Waite, H. R., M. J. Donnelly, and L. J. Walters. 2018. Quantity and types of 
microplastics in the organic tissues of the eastern oyster Crassostrea virginica and Atlantic mud crab Panopeus herbstii from a Florida estuary. Marine Pollution Bulletin 129: 179-185. doi:10.1016/j.marpolbul.2018.02.026

Wang, J., Z. Tan, J. Peng, Q. Qiu, and M. Li. 2016. The behaviors of microplastics in the marine environment. Marine Environmental Research 113: 7-17. doi:10.1016/j.marenvres.2015.10.014

Ward, J. E., and D. J. Kach. 2009. Marine aggregates facilitate ingestion of nanoparticles by suspension-feeding bivalves. Marine Environmental Research 68: 137-142. doi:10.1016/j.marenvres.2009.05.002

Woods, M. N., M. E. Stack, D. M. Fields, S. D. Shaw, and P. A. Matrai. 2018. Microplastic fiber uptake, ingestion, and egestion rates in the blue mussel (Mytilus edulis). Marine Pollution Bulletin 137: 638-645. doi:10.1016/j.marpolbul.2018.10.061 Xu, X.-Y., W. T. Lee, A. K. Y. Chan, H. S. Lo, P. K. S. Shin, and S. G. Cheung. 2017. Microplastic ingestion reduces energy intake in the clam Atactodea striata. Marine Pollution Bulletin 124: 798-802. doi:10.1016/j.marpolbul.2016.12.027 Zhang, H. 2017. Transport of microplastics in coastal seas. Estuarine, Coastal and Shelf Science 199. doi: $10.1016 /$ j.ecss.2017.09.032 


\section{Chapter 3: Microplastic Exposure by Razor Clam Recreational Harvester- Consumers Along a Sparsely Populated Coastline}

Special note: This article was first submitted to the journal Frontiers in Marine Science: Marine Pollution in August 2020 and was accepted for publication on Oct 23, 2020.

\subsection{Introduction:}

Coastal organisms are subjected to a myriad of environmental stressors ranging from the predictable, such as changing tides, predation (e.g., by sea otters, fish, birds and whales), and seasonal food availability, to the less predictable including storm events, disease, toxins, and environmental contaminants. Though numerous definitions exist, microplastics (MPs) - polymers between $1 \mu \mathrm{m}$ and $5 \mathrm{~mm}$ in size (Frias and Nash 2019)represent a diverse contaminant suite (Rochman et al. 2019). These particles, either manufactured at this size or formed as breakdown products of larger plastic items, make their way to coastal environments via household gray water, wastewater treatment plant effluent, stormwater, rivers, atmospheric deposition and other means (e.g., Napper et al. 2016; Lebreton et al. 2017; Mintenig et al. 2017; Zhang 2017; Zhang et al. 2020a; Zhang et al. 2020b). Present in coastal and marine environments worldwide, plastics are incorporated into all environmental compartments (air, water, sediment, sand, soil, biota) and affect roughly 700 known species to date-a number that continues to grow with the addition of new research (Provencher et al. 2017). MPs have been found in a variety of edible seafood species globally (e.g., Van Cauwenberghe \& Janssen 2014; Li et al. 2015; Rochman et al. 2015; Davidson and Dudas 2016; Lusher et al. 2017; Phuong et al. 2018), suggesting that marine predators and even human consumers of these species are exposed to MPs; however there are also myriad other non-seafood human consumables known to 
contain MPs including drinking water (e.g. Erkes-Medrano et al. 2018; Tong et al. 2020), table salt (e.g. Kim et al. 2018; Cho et al. 2019; Lee et al. 2019), milk (KutralamMuniasamy et al. 2020), honey (Liebezeit and Liebezeit 2013), beer (Liebezeit and Liebezeit 2014) and packaged meats (Kedzierski et al. 2020). With trophic transfer of MPs previously demonstrated in laboratory settings (Farrell and Nelson 2013; Nelms et al. 2018), there is little doubt that MPs are now inextricably incorporated into marine food webs and the human diet (Carbery et al. 2018; Barboza et al. 2018).

The Pacific Razor clam (Siliqua patula) is found on intertidal beaches along the Pacific coast of North America from Alaska to southern California (Link 2000). On the Olympic Peninsula, Washington (WA), United States (U.S.) which supports the largest population of harvest-sized individuals within the species' range, razor clams rely on the rich coastal waters to settle and grow (Huppert and Trainer 2014). This historicallyimportant species is a key traditional food and cultural resource, and serves as a vital form of income for members of the Quinault Indian Nation and other Olympic Coast peoples (Crosman et al. 2019).

While there is a distinctive lack of data on the prevalence and effects of MPs in commercially-important North American fishery species (Baechler et al. 2020a), recent research indicates that Pacific Northwest bivalves from less developed coastal areas are not immune to MP contamination (Davidson and Dudas 2016; Covernton et al. 2019; Baechler et al. 2020b; Martinelli et al. 2020). Determining the prevalence of MPs in organisms from varied geographies provides context for environmental concentrations, bioavailability to marine species and potential risk to human consumers. Investigating 
MP prevalence in marine and seafood species from relatively undeveloped coastal areas contributes to our understanding of the range of environmental and human exposure to MPs through seafood consumption in areas of relatively low human impact. MPs become incorporated into bivalves through ingestion or adherence to soft tissues (e.g., de Witte et al. 2014; Mathalon and Hill 2014; Kolandhasamy et al. 2018; Teng et al. 2019; Abidli et al. 2019), with potentially negative physiological impacts including increased respiration, altered reproduction and feeding, inflammation, neurotoxicity, and decreased energy reserves (e.g., von Moos et al. 2012; Avio et al. 2015; Sussarellu et al. 2016; Ribeiro et al. 2017; Xu et al. 2017; Bour et al. 2018).

We initiated this study on the sparsely populated Olympic Coast, WA, U.S. to determine: 1) microplastic burdens in Pacific razor clams from the Olympic Coast; 2) annual human microplastic exposure ranges from Olympic Coast razor clam consumption based on clam preparation styles, consumption frequency and consumer demographics; and 3) level of knowledge and concerns Olympic coast razor clam harvesters have regarding microplastic exposure from seafood.

We expected MPs would be present in Olympic Coast razor clams, as has been found in other filter-feeding bivalves (clams, oysters) in the region (e.g., Davidson and Dudas 2016; Covernton et al. 2019; Baechler et al. 2020b; Martinelli et al. 2020) and in a number of clam species globally (e.g., Li et al. 2015; Su et al. 2018; Abidli et al. 2019; Sparks 2020), but that MP burdens would be highest at northernmost sites due to outflow from Puget Sound and the Salish Sea- waterbodies adjacent to the populous Seattle metropolitan area abutting the Olympic Peninsula. This hypothesis was founded upon the 
assumptions that densely populated areas can lead to high concentrations of MPs in the coastal marine environment, due to land-based inputs (Barnes et al. 2009; Hantoro et al. 2019), and that waterborne MP concentrations partially dictate bivalve MP burdens (Qu et al. 2018). We predicted Puget Sound and the Salish Sea would transport substantial waterborne MPs to the Olympic Coast, based on existing hydrographic models of water movement from the highly populated Salish Sea region to the sparsely populated northern Olympic Coast (Pirhalla et al. 2009) and MP transport in coastal littoral drift cellspockets of water (and associated particulates or contaminants) of varying energy levels that move alongshore (Black et al. 2018; Horn et al. 2019).

We hypothesized annual Olympic Coast razor clam harvester-consumer MP exposure would vary depending on clam preparation style, ethnicity, and frequency of consumption. This hypothesis was based on the knowledge that some ethnicities consume more seafood per capita than the general population, resulting in greater exposure to seafood-associated contaminants (Sechena et al. 1999; Mahaffey et al. 2009; EPA 2014; Cisneros-Montemayor et al. 2016). Lastly, we hypothesized that razor clam harvesters would possess varying knowledge and concerns about MPs in seafood.

\subsection{Methods:}

\section{Study area context}

"When the tide is out, the table is set" is a common saying on the Olympic Peninsula, the rugged coastal region which forms the western border of WA, U.S. (Charles et al. 2004). In this ecologically-productive area, as in others across North 
America, harvest of the nearshore seafood bounty by Native Americans has occurred since time immemorial and is significantly integrated into local indigenous culture, economy, gastronomy and food security (Olson 1936; Charles et al. 2004; Anderson and Parker 2009; Lepofsky et al. 2015).

The Olympic Coast is a region of low human presence relative to other coastal areas in North America. It is sparsely populated by about 195,000 people at a density of 12 people $/ \mathrm{km}^{2}$ (30 people $/ \mathrm{mile}^{2}$ ) in coastal Jefferson, Clallam, Grays Harbor, and Pacific counties (U.S. Census Bureau 2012), and a very low proportion of developed lands compared to other land use types based on 2010 data (Appendix C: Chapter 3; NOAA 2020). For comparison, in the U.S., average coastal population density (excluding Alaska) was 446 people per square mile in 2010 (NOAA Office for Coastal Management 2020). While the west coast of the U.S. has the state with the highest coastal-dwelling population (California-26.5 million people), the east and gulf coasts have states with the second through fifth highest coastal populations (New York-16 million people; Florida15.3 million people; New Jersey-7.1 million people; Texas-6.6 million people), providing evidence that coastal living is prized nationwide (Crossett et al. 2013; NOAA Office for Coastal Management 2020). Unfortunately, land development, particularly near densely populated coastlines, can impact coastal ecology through environmental degradation such as loss of habitat for native species, erosion, and pollution in various forms (nutrient, chemical, noise, light, plastic).

The allure of the razor clam attracts thousands of visitors to the Olympic Coast's sandy shores annually, as they try their luck at clamming during one or more recreational 
fishery openers. The recreational fishery injects what are usually sleepy coastal towns with visitors, filling hotels and restaurants to capacity, and bringing millions of dollars annually into coastal community economies. Roughly 250,000 clam digger trips are logged in this region each year (Huppert and Trainer 2014).

Razor clams are co-managed in Washington by both the Department of Fish and Wildlife (WDFW) and by tribal governments (Wyer 2013). Tribal (ceremonial, subsistence and commercial) and state (recreational and commercial) fisheries have unique rules for who can participate and where harvest can occur. The Quinault Indian Nation is the sole manager and harvester of razor clams on beaches within their reservation boundaries (Figure 1). The Quinault Nation's treaty rights extend to beaches north and south of their reservation, within their legally defined "usual and accustomed fishing grounds" (U\&A), where they co-manage razor clams with WDFW and other tribes. Fifty percent of total allowable harvest is reserved per treaty between the United States and the Quinault people on U\&A areas off-reservation (shared with the Hoh Tribe on Kalaloch Beach to the north), with the remainder available for recreational harvest in the state-managed fishery (Anderson 1999). Commercial and subsistence razor clam harvest off-reservation is regulated by Quinault for tribal members at Copalis, Mocrocks, and Kalaloch beaches. Recreational harvest is permitted by WDFW on set harvest dates, and is open to anyone with a Washington shellfish harvest permit (Crosman et al. 2019). 


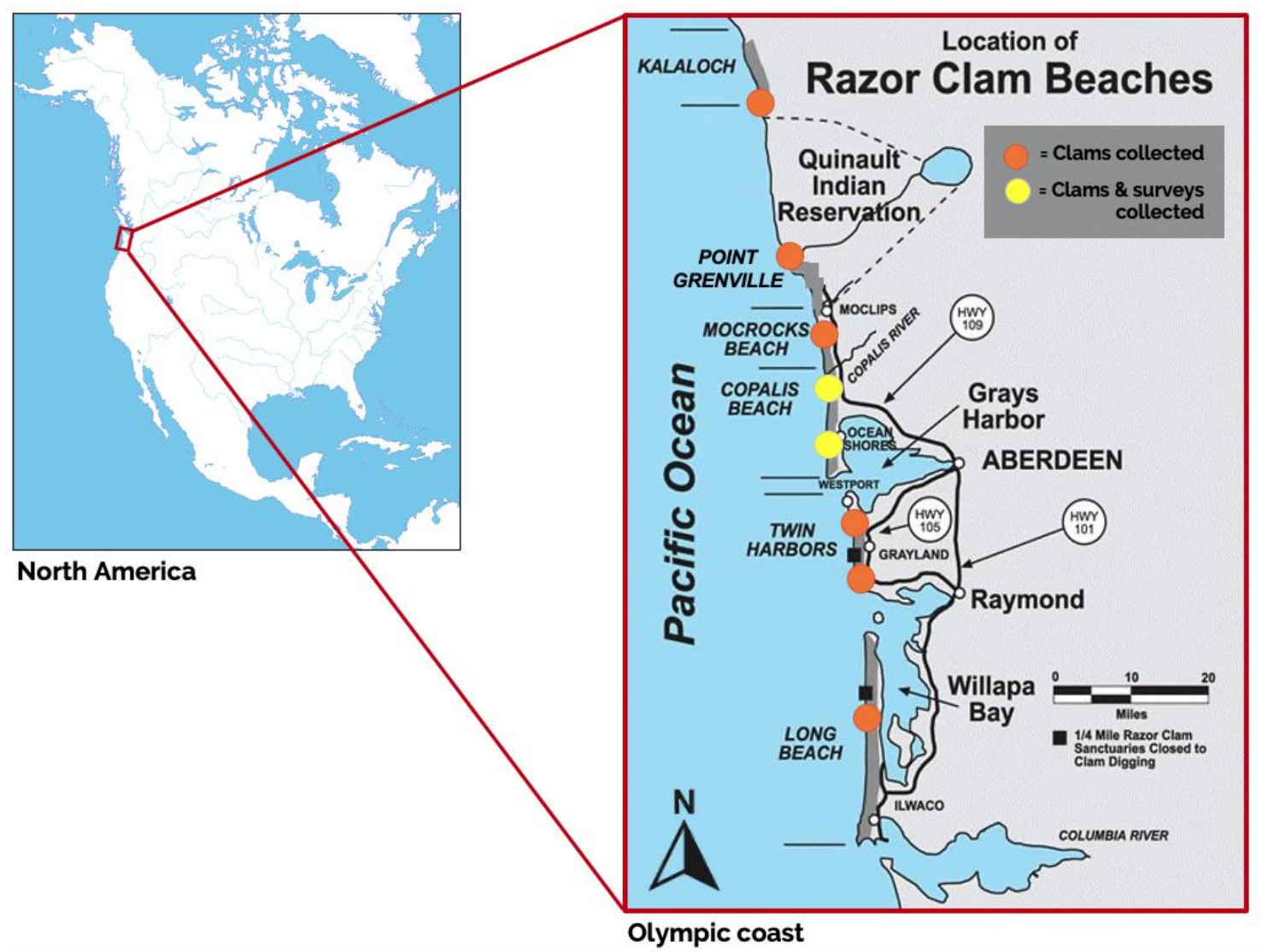

FIGURE 1. Modified publicly-available map of recreational and commercial razor clam beaches on the Olympic Peninsula, Washington, with razor clam collection sites (orange circles) and sites where both razor clams were collected and clam harvester surveys were conducted (yellow circles) in April 2018. Sample beaches included (from North to South): Kalaloch beach, Point Grenville beach (within the Quinault Indian Reservation), Mocrocks Beach, Copalis Beach, Twin Harbors and Long Beach. Original map source: http://wdfw.wa.gov/fishing/shellfish/razorclams/.

Microplastic prevalence in study species

\section{Sample sites and collection}

Olympic Peninsula clams were collected from eight coastal beaches (Figure 1;

Kalaloch, Point Grenville, Mocrocks, Copalis, South Copalis, North Twin Harbor, South

Twin Harbor, and Long Beach) in April 2018 to quantify types and burdens of MPs in their tissues. Fifteen clams were collected at each of the eight sites, except at Mocrocks beach where only fourteen were collected due to challenging harvest conditions. Razor 
clams sampled averaged $69.90 \pm 2.63 \mathrm{~g}$ wet body weight per individual $(\mathrm{range}=4.66-$ $167.02 \mathrm{~g})$; therefore, on average, roughly $1.05 \mathrm{~kg}$ of razor clam tissue was collected per site (except at Mocrocks beach due to only fourteen clams being collected). Clams were not selected by size; rather, the first fifteen clams obtained per site were retained for analysis. Clams were transported in clean, covered 2L glass mason jars on ice to the Applied Coastal Ecology lab at Portland State University in Portland, Oregon (OR), where the exteriors of the organisms were rinsed with filtered deionized (DI; Shelco MicroVantage WGPS0.2-20S7S213 filtered to $0.22 \mu \mathrm{m}$ ) water and biological measurements (shell length in mm, body tissue weight in g) were collected. Individual organisms were processed as either whole ( $\mathrm{n}=7$ individuals for each site), gut-tissue separated ( $\mathrm{n}=3$ individuals for each site, divided into 3 gut-only and 3 tissue-only samples), or cleaned samples ( $\mathrm{n}=5$ per site). "Whole" organisms were minimally processed except for shells being rinsed, to mimic MP burdens if the clam was consumed by an animal predator. "Gut-tissue" samples (stomach, intestine, and crystalline style) were separated from "non-gut tissue" samples (all remaining tissue; Table 1). "Cleaned" samples were prepared as if to be eaten by a human consumer; in order to remove gritty sand and other debris inside of or stuck to the clam, the tip of the siphon was removed, and both the incurrent and excurrent siphons were split using cleaned stainless steel scissors and rinsed thoroughly under a running filtered DI water tap. The clam foot was also split and thoroughly rinsed under a running filtered DI water tap. Digestive organs and gills were removed using cleaned stainless steel scissors (Table 1). Each sample was rinsed into individual cleaned and labeled mason jars and frozen at $-20^{\circ} \mathrm{C}$ (Table 1). Of 
the 138 clam samples analyzed in this study, 52 were whole, with others separated into gut and tissue samples ("gut-tissue"; $n=24$, and "non-gut tissue", $n=23$ respectively), or fully cleaned ("cleaned"; $n=39$ ).

TABLE 1. Descriptions of the four clam sample types included in this study.

\begin{tabular}{|c|c|c|c|c|c|}
\hline Sample type & Sample type description & $\begin{array}{l}\text { \# of } \\
\text { Samples }\end{array}$ & $\begin{array}{l}\text { Avg \# } \\
\text { MP/sample }\end{array}$ & $\begin{array}{l}\text { Range \# } \\
\text { MP/sample }\end{array}$ & $\begin{array}{l}\text { MPs previously reported for this } \\
\text { species and sample type? }\end{array}$ \\
\hline Whole & $\begin{array}{l}\text { Shell rinsed with filtered DI water; was } \\
\text { minimally prepared as if consumed by } \\
\text { an animal predator. Includes whole } \\
\text { organism (including gut-tissue and } \\
\text { nongut tissue) }\end{array}$ & 52 & $6.75 \pm 0.60$ & $0-20$ & Yes; Baechler et al. 2020b \\
\hline Gut-tissue & $\begin{array}{l}\text { Shell rinsed with filtered DI water; } \\
\text { includes stomach, intestine, and } \\
\text { crystalline style }\end{array}$ & 24 & $7.88 \pm 0.71$ & 3-16 & Yes; Baechler et al. 2020b \\
\hline Nongut-tissue & $\begin{array}{l}\text { Shell rinsed with filtered DI water; } \\
\text { includes all remaining tissue after gut- } \\
\text { tissue was separated }\end{array}$ & 23 & $4.96 \pm 0.56$ & $0-12$ & Yes; Baechler et al. 2020b \\
\hline Cleaned & $\begin{array}{l}\text { Shell rinsed with filtered DI water; was } \\
\text { prepared as if to be eaten by a human } \\
\text { consumer. The tip of the siphon was } \\
\text { removed. The incurrent and excurrent } \\
\text { siphons and foot were split using } \\
\text { cleaned stainless steel scissors and } \\
\text { rinsed thoroughly under a running } \\
\text { filtered DI water tap. Digestive organs } \\
\text { and gills were removed using cleaned } \\
\text { stainless steel scissors }\end{array}$ & 39 & $3.44 \pm 0.25$ & $0-6$ & No \\
\hline
\end{tabular}

Notes: $\mathrm{DI}=$ Deionized (filtered to $22 \mu \mathrm{m}$ ); $\mathrm{MP}=$ suspected microplastics; $\mathrm{Avg}=$ average; $\#=$ number. Error reported for Avg \# MP/sample is Standard Error.

\section{Sample Processing}

Samples were thawed and digested individually using the protocol described in Baechler et al. (2020b). In brief, samples were individually chemically digested using a $10 \%$ potassium hydroxide $(\mathrm{KOH})$ solution, then underwent a second $10 \% \mathrm{KOH}$ digestion combined with hypersaline density separation (330g/L Fisher Chemical Certified ACS Crystalline $\mathrm{NaCl}$ ) and were visually analyzed for MPs under a Leica M165C stereomicroscope (10-120x magnification). Each suspected MP encountered was photographed with a Leica IC80 HD camera connected to a computer running Leica 
Application Suite X imaging software. Particle category (bead, fiber, fiber bundle, film, fragment, foam, unknown), color, and maximum length were recorded. All clam sample types (whole, gut-tissue, non-gut tissue, cleaned) underwent identical procedures during collection, transport, digestion and microscope analysis. In a randomly-selected subset of approximately $10 \%$ of suspected MPs (53 total) extracted from whole and cleaned clams, material types were determined using a Thermo Nicolet is20 Fourier-transform infrared spectrometer (FTIR) and iN5 microscope fitted with an Attenuated Total Reflectance accessory and germanium tip running at $128-512$ scans in the Brander laboratory at Oregon State University. Spectral outputs were compared to FTIR spectral libraries (Omnic polymer database, Primpke et al. 2018; Primpke et al. 2020), with a 70\% minimum match threshold to determine a quality spectrum and material type. Material type was determined by the match with the highest percentage.

\section{Quality Assurance/Quality Control}

MPs and other anthropogenic fibers (AFs) are airborne, waterborne, and present on surfaces, and are therefore inadvertently introduced to samples during laboratory processing or analysis. These AFs - MPs or otherwise - labeled 'contamination', are important to quantify, as they provide context for final particle counts. To minimize contamination, clams were immediately rinsed with filtered DI water and placed in cleaned, rinsed and covered $2 \mathrm{~L}$ mason jars after field collection. One hundred percent cotton clothing and lab coats, as well as nitrile gloves were worn at all times in the laboratory during sample processing, chemical digestions, and microscope analyses. 
Nitrile gloves were changed after every sample, after handling tools or touching surfaces. Glassware and tools were all rinsed 3 times with filtered DI water $(0.22 \mu \mathrm{m}$ pore size $)$ between uses, and glassware was covered with cleaned watch glasses at all times. To quantify contamination, two control types (procedural and microscope blanks) were used to provide a snapshot of AFs inadvertently introduced into clam samples during laboratory processing and analysis (Brander et al. 2020). Procedural controls were samples of 50ml filtered DI water run through the same chemical digestion and sieving steps as other sample types; microscope blanks were glass petri dishes filled with filtered DI water placed on the microscope base and left open to the air during visual inspection of samples for MPs (Baechler et al. 2020b; Appendix D: Chapter 3). One procedural control was processed during each of the four weeks of laboratory chemical digestions $(n=4)$, and one microscope blank was processed per sample immediately following visual microscope analysis of that sample $(n=145)$.

\section{Calculations and Statistical analyses}

MPs in this study refers to post-digestion visually-identified fibers and few particles suspected to be plastics, a subset (10\%) of which were validated using FTIR; while the validated subset was randomly selected, we cannot be certain of the material types or origins for all MPs in this study. To identify any differences in MP burden between sample sites or between sample types (whole, gut-only, tissue-only, and cleaned) analysis of variance (ANOVA) and post-hoc Tukey tests were conducted. Variables including the number of MPs per sample and per gram of tissue (MP g-1 tissue) were 
square root transformed to normalize data prior to conducting statistical analyses. Linear regression models were used to examine relationships between biological parameters (shell length, body tissue wet weight) and MP burdens (per whole individual and $\mathrm{g}^{-1}$ tissue) and were expressed as number of MPs per sample or $\mathrm{g}^{-1}$ tissue (wet weight; whole organisms only). The statistical cutoff (alpha) for all tests was 0.05 with standard error (SE) reported.

\section{Razor clam harvester questionnaire}

\section{Questionnaire sites and protocol}

Written questionnaires were administered to recreational razor clam harvesters 18 years of age or older after concluding clamming activities at Mocrocks and Copalis beaches on April 21-22, 2018 (Figure 1). Frequencies of razor clam consumption, preparation type, number of individual razor clams consumed per meal, and demographics of respondents were determined using these questionnaires (Appendix E: Chapter 3). Estimates of recreational razor clam harvester MP exposure were calculated based on self-reported razor clam consumption frequencies. While not central to research questions, data on consumption of other non-razor clam marine seafood species were also collected to provide further context to study results (Appendix F: Chapter 3).

The questionnaire surveying effort occurred during state-managed recreational fishery openings on two days in April and not during tribal commercial or subsistence fishery opening dates. Thus, local tribes (Quinault, Quileute, Hoh, and others) were poorly represented in the survey. Questionnaires were administered within two hours of 
low tide each day, with surveys beginning at 10:00am (low tide at 11:38am) and 11:00am (low tide at 12:30pm) on April 21 and 22, respectively. Three teams of two surveyors dispersed along the beach to cover as large an area as possible. Surveyors monitored the shoreline for every sixth clam harvester party that visually indicated they had completed clamming activities (i.e., turning their backs to the shore and walking towards the vehicle line carrying clam bag, shovel and any other equipment or personal effects). Surveyors intercepted a clam harvesting party, provided a brief description of the research project and asked if a representative of the party would be willing to complete a questionnaire. Upon agreement, they were provided a clipboard with the questionnaire and a pencil attached. Respondents wrote in answers themselves unless they requested for surveyors to write as they dictated. Responses were at-will (not required) except the first question indicating the respondent was 18 years of age or older (Appendix E: Chapter 3); therefore, not all respondents answered every question.

\section{MP exposure calculations and statistical analyses}

MP exposure ranges of Olympic Coast razor clam harvester-consumers from razor clam consumption were calculated by multiplying minimum and maximum positive consumptive responses (i.e., smallest nonzero consumption frequency) per season (winter, spring, summer, fall) by average suspected MP burden for whole or cleaned clams across all eight sample sites. These exposure ranges include a combination of MPs and fibers of unknown origins, based on FTIR results for randomly-selected fibers in whole and cleaned clam samples. Seasonal totals were combined to generate MP 
exposure estimates. For our purposes, each season was represented evenly in three-month (13.05 week) blocks.

Questionnaire data were plotted using Microsoft Excel and the R-studio statistical program (v1.2.1335). ANOVA, post-hoc Tukey tests, and Welch's T-tests were run using the .aov, tukey.test and t.test functions in R-studio (R Core Team 2020) to identify differences in MP exposure among demographic groups based on gender, age, income, ethnicity or education level. Standard error $(\mathrm{SE}$; alpha $=0.05)$ was reported with averages. Razor clam consumption by ethnicity was reported but not analyzed for statistical differences due to small sample size for some ethnicities; instead, a Welch's t-test was performed to elucidate differences in razor clam consumption between White/Caucasian and all other ethnic groups. For the single open-ended questionnaire item "Please expand on what concerns you have about microplastics in your food", responses were categorized into seven themes based on the short, written responses provided (Table 3). 


\subsection{Results:}

\section{Biological measurements}

Razor clams averaged $115.71 \pm 1.29 \mathrm{~mm}$ shell length $($ range $=63.91-156.76 \mathrm{~mm})$ and $69.90 \pm 2.63$ grams $(\mathrm{g})$ wet body weight (range $=4.66-167.02 \mathrm{~g})$, as the first 15 clams harvested per site were retained regardless of size. Average clam size was similar for all sites except for the northernmost Kalaloch beach, where clams were significantly smaller than other sites for both shell length $(\operatorname{avg}=102.85 \pm 2.25 \mathrm{~mm}$; range $=81.38-114.88 \mathrm{~mm}$; $\left.\mathrm{F}_{7,43}=4.00, \mathrm{p}=0.002\right)$ and wet body weight $(\operatorname{avg}=32.45 \pm 2.12 \mathrm{~g} ;$ range $=15.37-45.10 \mathrm{~g}$; $\left.\mathrm{F}_{7,44}=7.60, \mathrm{p}<0.0001\right)$.

\section{Microplastic characteristics and identification}

Suspected MPs were found in razor clams at all eight sample sites. In total, 799 suspected MPs were found in the 138 clam samples collected during this study. Over $99 \%$ of suspected MPs encountered were microfibers $(n=793)$ with an average length of $1.33 \pm 0.04 \mathrm{~mm}($ range $=0.11-7.84 \mathrm{~mm}$; Appendix G: Chapter 3). Other categories represented were: unknown $(n=3)$, fiber bundles $(n=2)$, and fragments $(n=1)$. Colorless, blue, gray, and black were the most commonly observed colors at $55.19 \%(n=441)$, $19.27 \%(n=154), 12.27 \%(n=98)$ and $4.63 \%(n=37)$, respectively (Appendix H: Chapter 3). FTIR analysis of 53 randomly-selected suspected MPs (10.83\% of suspected MPs encountered in whole clams and $10.45 \%$ of suspected MPs encountered in cleaned clams) yielded reliable matches for 52 fibers and verified that a total of $80.77 \%$ of the 52 fibers with matches were either synthetic $(48.08 \%, \mathrm{n}=25)$, including polyethylene terephthalate $(n=21)$, polyester $(n=3)$, and nylon $(n=1)$, or semi-synthetic $(32.69 \% ; n=17)$, including 
cellulose acetate $(n=11)$ and cellophane $(n=6$; Appendix I: Chapter 3, Appendix J:

Chapter 3). Cellulose, a naturally-derived material, was also identified $(n=10 ; 19.23 \%)$.

One additional suspected MP was analyzed but its spectral match did not meet the $70 \%$ minimum threshold; material type for that fiber was unconfirmed and reported as "low spectral match". The average match used for identification was $86.6 \% \pm 1.0 \%$.

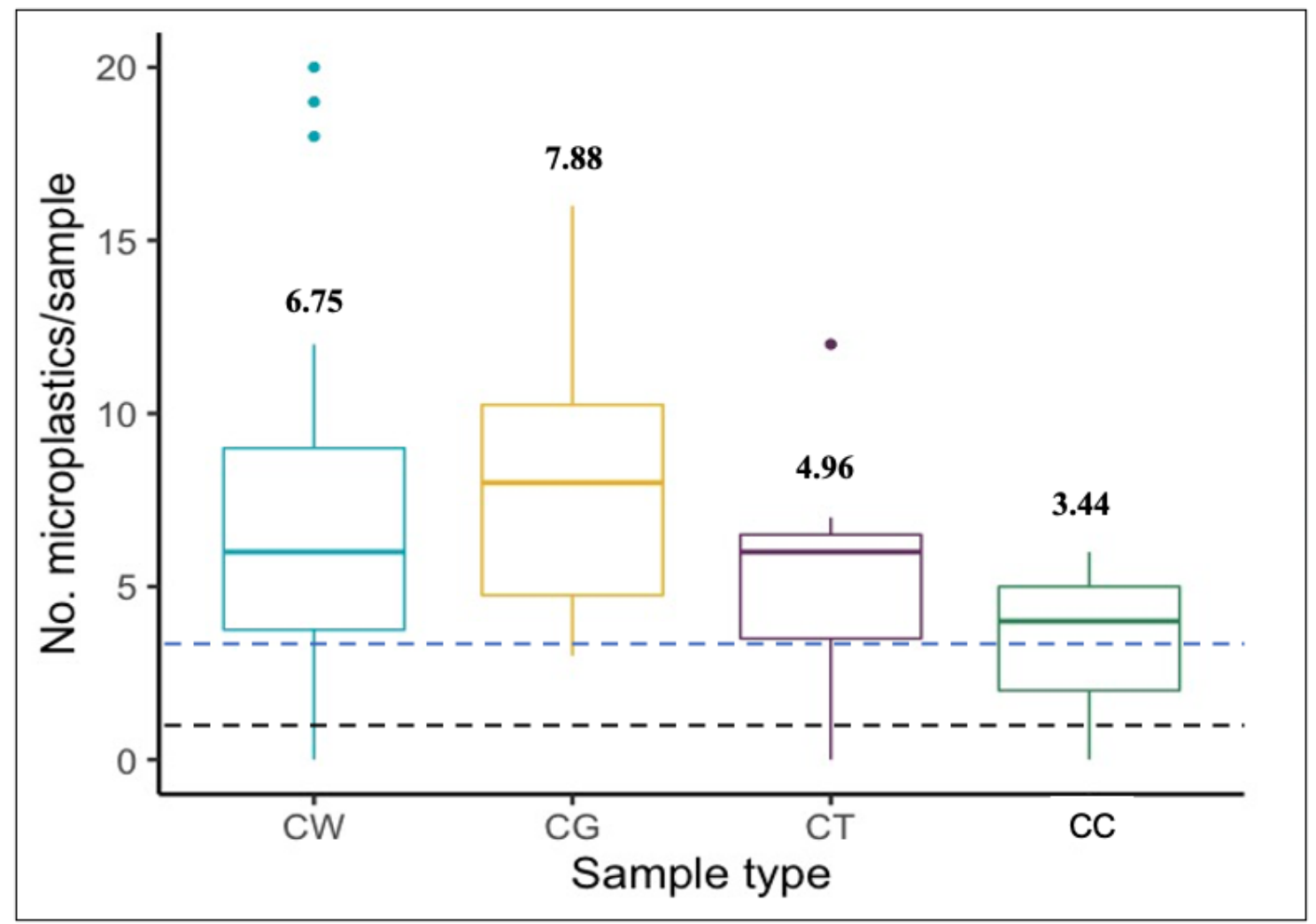

FIGURE 2. Number of microplastics (MPs) by sample type. $\mathrm{CW}=$ whole clam $(\mathrm{n}=52)$; $\mathrm{CG}=$ gut-tissue only $(\mathrm{n}=24) ; \mathrm{CT}=$ tissue-only $(\mathrm{n}=23) ; \mathrm{CC}=$ cleaned clam $(\mathrm{n}=39)$. No.= number. Black hashed line indicates average microscope blank contamination (Avg=0.23 MPs/sample; $n=145)$. Blue hashed line indicates average procedural control contamination (Avg=3.25 MPs/sample; $n=4)$. Bold numbers above boxes indicate average number of MPs per sample type.

\section{Microplastics prevalence}

Whole clams and gut-tissue samples contained more MPs per sample than cleaned clams ( $\mathrm{p}=0.0004$ and $\mathrm{p}<0.0001$, respectively), and gut-tissue samples contained 
significantly more MP than non-gut tissue ( $\mathrm{p}=0.017$; Figure 2$)$. Across all sites, average whole clam suspected MP burden was $6.75 \pm 0.60$ (range $=0-20, n=52$; Figure $3 \mathrm{~A})$. For gut-tissue, non-gut tissue, and cleaned samples, average MP burdens across all sites were $7.88 \pm 0.71(n=24 ;$ range $=3-16), 4.96 \pm 0.56(n=23 ;$ range $=0-12)$, and $3.44 \pm 0.25(n=$ 39 ; range $=0-6$ ), respectively. When comparing the number of MPs in all four sample types (Table 1$)$ across all sites, significant differences were identified $\left(\mathrm{F}_{3,134}=9.858, \mathrm{p}<\right.$ $0.0001)$. For whole clams, average $\mathrm{MP} \mathrm{g}^{-1}$ burden was $0.15 \pm 0.03$ (range $=0-1.17, \mathrm{n}=52$; Figure 3B). $\mathrm{MP} \mathrm{g}^{-1}$ tissue differed by site, with higher $\mathrm{MP} \mathrm{g}^{-1}$ tissue found at the northernmost Kalaloch site than all other sites $\left(\mathrm{F}_{7,44}=7.171, \mathrm{p}<0.0001\right)$. Site-specific differences in MP g ${ }^{-1}$ tissue were identified between Kalaloch and: Copalis $(\mathrm{p}=0.0002)$, Long Beach $(p<0.0001)$, Mocrocks $(p=0.002)$, North Twin Harbor $(p=0.003)$, South Copalis ( $\mathrm{p}<0.0001)$, South Twin Harbor $(\mathrm{p}=0.0006)$, and Point Grenville $(\mathrm{p}=0.01$; Figure 3A-B). In contrast to differences in MP $\mathrm{g}^{-1}$ tissue, the number of MPs per clam differed minimally across sites $\left(\mathrm{F}_{7,44}=1.892, \mathrm{p}=0.09\right)$. Number of MPs did not differ among sites for gut-tissue $\left(\mathrm{F}_{7,16}=1.095, \mathrm{p}=0.41\right)$ or non-gut-tissue samples $\left(\mathrm{F}_{7,15}=1.076\right.$, $\mathrm{p}=0.42)$, but did for cleaned clams $\left(\mathrm{F}_{7,31}=3.020, \mathrm{p}=0.02\right)$ for two site pairings: Copalis and South Copalis $(\mathrm{p}=0.01)$ and South Copalis and North Twin Harbor $(\mathrm{p}=0.04)$. Neither clam shell length (in $\mathrm{mm} ; \mathrm{F}_{1,49}=0.941, \mathrm{p}=0.34$ ) nor body weight ( $\mathrm{g}$ wet weight; $\left.F_{1,50}=0.010, p=0.92\right)$ correlated with the number of MPs per whole organism. 


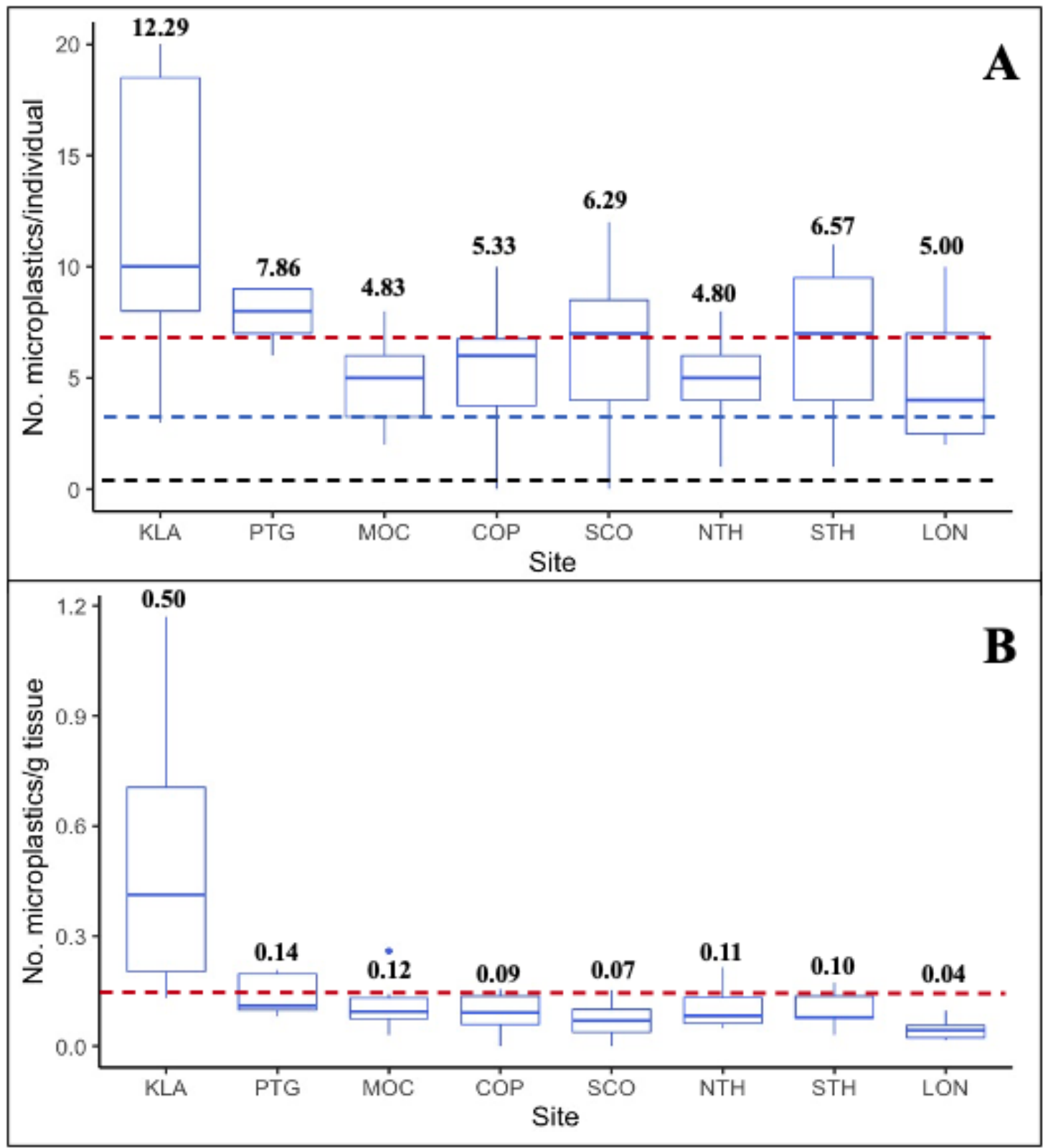

FIGURE 3 (A-B): Number of microplastics (MPs)- (A) Per individual whole razor clam, with red line indicating average number of MPs for all eight sites (Avg=6.75 MPs/individual), black hashed line indicating average microscope blank contamination (Avg=0.23 MPs/sample; $n=145$ ), and blue hashed line indicating average procedural control contamination (Avg=3.25 MPs/sample; $n=4)$; and (B) Per gram of tissue (wet weight), with red line indicating average number of MPs per gram of tissue (wet weight) for all eight sites ( $\mathrm{Avg}=0.15 \mathrm{MP} \mathrm{g}^{-1}$ tissue). Bold numbers above boxes indicate average number of MPs per sample type. No.= number. Sites are arranged north to south by latitude. KLA= Kalaloch beach $(n=7)$, PTG= Point Grenville (within the Quinault Indian Reservation boundary; $n=7$ ), MOC= Mocrocks Beach $(n=6), \mathrm{COP}=$ Copalis Beach $(\mathrm{n}=6), \mathrm{SCO}=$ South Copalis Beach $(\mathrm{n}=7), \mathrm{NTH}=$ North Twin Harbor $(\mathrm{n}=5)$, $\mathrm{STH}=$ South Twin Harbor $(\mathrm{n}=7)$, LON= Long Beach $(n=7)$. 


\section{Quantifying microplastic contamination}

In total, 46 suspected MPs were identified as contamination from microscope blanks $(n=145)$ and procedural controls $(n=4)$. On average, suspected MP contamination in microscope blanks was $0.23 \pm 0.05$ (range $=0-2$ ), and in procedural controls was 3.25 \pm 0.85 (range $=1-5 ;$ Figure 2). Average MP length detected as contamination was $1.60 \pm$ $0.15 \mathrm{~mm}$ (range: $0.12-3.6 \mathrm{~mm}$ ). One hundred percent (100\%) of suspected MPs in microscope blanks and procedural controls were microfibers and were colorless (77.8\%; $n=35)$, blue $(15.6 \% ; n=7)$, black $(4.4 \% ; n=2)$, or gray $(2.2 \% ; n=1)$. Neither microscope blank nor procedural control MPs was subtracted from clam MP burdens because procedural controls were low in number and were intended to identify a range of contamination during laboratory processing, with microscope blanks showing a range of contamination during microscope analyses. Reported MP burdens in the four clam sample types may be lower than reported given ambient contamination found in microscope blank and procedural control samples. Some cleaned razor clams contained fewer MPs than the maximum contamination found in our controls; in these cases, our clam MP burdens may also be higher than would be expected in the environment.

\section{Questionnaire respondent demographics}

The two-day survey effort at Mocrocks and Copalis beaches yielded 107 questionnaires from recreational razor clam harvesters representing an array of ethnicities, incomes, educational backgrounds, and ages. Questionnaire response rate was $94.7 \%$, as 6 of the 113 individuals asked to participate declined. Respondents were $56.2 \%$ 
male, $43.8 \%$ female (Figure 4A), and lived in 14 Washington counties including Benton $(n=3)$, Chelan $(n=1)$, Clallam $(n=2)$, Clark $(n=4)$, Franklin $(n=1)$, Grays Harbor $(n=6)$, King ( $(n=24)$, Kitsap $(n=5)$, Lewis $(n=3)$, Mason $(n=6)$, Pierce $(n=17)$, Skagit $(n=3)$, Snohomish $(n=12)$, and Thurston $(n=15)$. None of the 107 respondents dug razor clams to sell commercially in April 2017-April 2018. Roughly 96\% ( $\mathrm{n}=103)$ of questionnaire respondents reported their ethnicities. The majority of respondents $(79.6 \%)$ were White/Caucasian, and the remaining (20.4\%) were Asian, mixed race, Native American, Native Hawaiian or Pacific Islander, or Alaska Native (Figure 4B). Due to small sample size for most ethnic groups surveyed (White/Caucasian individuals: $n=82$; Asian: $n=10$; Mixed ethnicity: $n=6$; Native American: $n=2$; Native Hawaiian or Pacific islanders: $n=$ 2; and Alaska Native: $\mathrm{n}=1$ ); therefore, differences in razor clam consumption were analyzed between White/Caucasian (79.6\% of respondents) and all other ethnic groups (Non-White/Caucasian; 20.4\% of respondents). Most respondents reported an annual income range of $\$ 50,001-\$ 75,000$ U.S. dollars (Figure 4C). Respondent ages were lumped into groups; the youngest respondents were 18-28 years and the oldest were $62+$ years, but most (31.4\%) were 51-61 years of age (Figure 4D). 

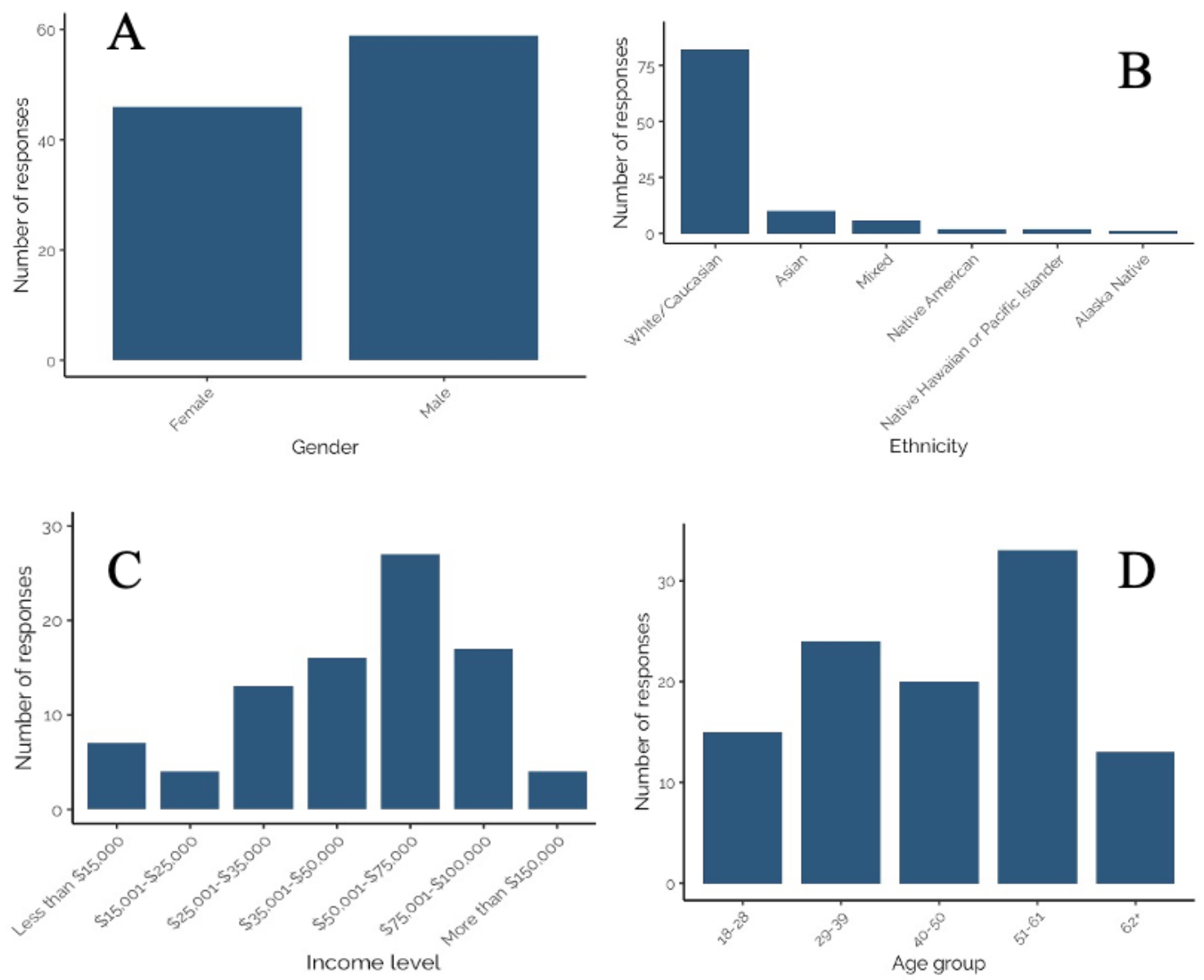

FIGURE 4 (A-D): From top left to bottom right- Number of Olympic Coast recreational razor clam harvester questionnaire responses by: (A) gender; (B) ethnicity; (C) income level; and (D) age group. Bold numbers above bars represent number of responses.

\section{Razor clam harvest and consumption}

While only $83.8 \%$ of questionnaire respondents reportedly consumed razor clams in the past year $(n=88)$, all $(100 \% ; n=107)$ participated in recreational razor clamming activities during the survey period (April 21-22, 2018). Razor clams consumed by respondents were obtained in a variety of ways; the majority $(76.0 \% ; n=76)$ harvested the clams they ate, while some individuals obtained their clams in multiple ways $(11.0 \%$; $n=11)$, got clams from friends or family $(4.0 \% ; n=4)$, purchased them $(2.0 \% ; n=2)$, or didn't know or obtained clams in other ways $(3.0 \%$; $=3)$. The average number of razor 
clams consumed per meal was $4.27 \pm 0.27$ clams (range $=0-10)$; however, most respondents consumed either three or five clams per sitting $(23.3 \%$ or $18.9 \%$, respectively).

The majority of respondents $(88.4 \%$; $n=91)$ consumed razor clams without guts, while some did not know if they consumed the gut or not $(9.7 \% ; n=10)$. One individual reported sometimes consuming them with, and sometimes without guts $(1.0 \% ; n=1)$, and one individual reported consuming them with guts $(1.0 \% ; n=1)$. More respondents reported consuming clams in the spring $(81.1 \% ; n=77)$ than winter $(72.8 \% ; n=67)$, fall $(70.4 \% ; n=62)$, or summer $(57.1 \% ; n=48)$ seasons.

To elucidate patterns in clam consumption, we considered demographic factors including gender, ethnicity, income and age group. The number of clams consumed per sitting varied by gender (Figure 5A), with males consuming significantly more than females (males: $4.81 \pm 0.37$, females: $3.78 \pm 0.34 ; \mathrm{T}=-2.051, \mathrm{p}=0.04$ ). Clam consumption also varied by ethnicity, but these differences were not statistically analyzed due to low response numbers (as low as $n=1$ ) for some categories (Figure 5B). On average, Alaska Native and Native American respondents consumed the highest number of clams per sitting at $7.0(n=1)$ and $7.0 \pm 3.0(n=2)$, respectively. The next highest consumers of razor clams per sitting were Mixed ethnicity individuals (6.0 \pm 0.40 clams; $n=4)$, followed by Native Hawaiian or Pacific islanders $(4.50 \pm 4.50$ clams; $n=2)$, White/Caucasians (4.46 \pm 0.26 clams; $n=69)$, and Asians $(1.56 \pm 0.60 ; n=9)$. No difference was found when comparing number of clams consumed per meal for White/Caucasian and Non-White/Caucasian (all ethnicities except White/Caucasian; T= - 
$0.841, \mathrm{p}=0.41)$. The number of clams consumed per sitting did not vary by respondent income level (Figure 5C; $F_{7,73}=1.047, p=0.41$ ) or age group (Figure 5D; $F_{4,83}=0.924, p=$ $0.45)$.

In addition to razor clams, respondents reported consuming a variety of other common marine shellfish including bivalves (oysters, mussels, bay clams, hard shell clams, geoducks, scallops), crustaceans (Dungeness crab, other crab, lobster), gastropods (snails), and echinoderms (urchins; Appendix F: Chapter 3).
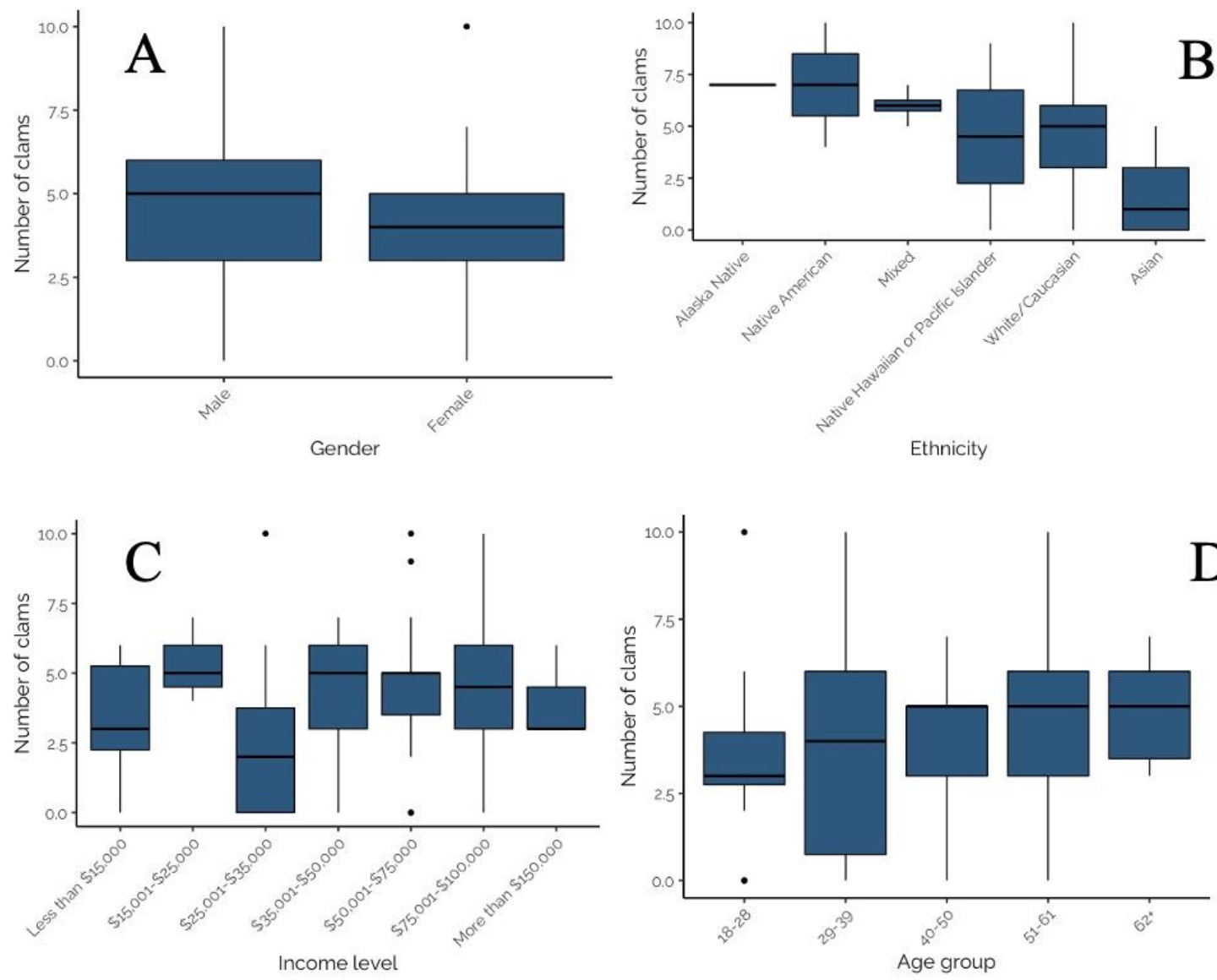

FIGURE 5 (A-D): From top left to bottom right- Number of razor clams consumed per sitting by Olympic Coast recreational razor clam harvester: (A) gender; (B) ethnicity; (C) income level; and (D) age group. Significant differences were identified between males and females (panel A; $\mathrm{p}=0.04$ ), but not by income level $(\mathrm{p}=0.41)$ or age $(\mathrm{p}=0.45)$.

Razor clam harvester-consumer microplastic exposure 
Using a combination of our razor clam MP burdens and questionnaire data, we estimated annual ranges of MP exposure through razor clam consumption by recreational harvester-consumers on the Olympic Coast (Table 2, Figure 6, Figure 7A-B).

TABLE 2. The estimated annual microplastic exposure ranges by Olympic Coast, WA razor clam harvester-consumers. MP exposures were rounded to the nearest 10 . The number of razor clams consumed per sitting, and minimum and maximum number of razor clam meals consumed per year were self-reported. Average number of microplastics for whole and cleaned razor clams were determined through analyses of clams collected from eight Olympic Coast sites. Minimum razor clam meals consumed include nonzero responses only.

\begin{tabular}{|c|c|c|c|c|c|c|c|c|}
\hline \multirow[b]{2}{*}{ Consumer group } & \multirow[b]{2}{*}{$\begin{array}{l}\text { Respondents } \\
\text { (\#) }\end{array}$} & \multirow[b]{2}{*}{$\begin{array}{c}\text { Avg \# clams } \\
\text { consumed / sitting }\end{array}$} & \multirow[b]{2}{*}{$\begin{array}{l}\text { Min clam meals } \\
\text { consumed /yr }\end{array}$} & \multirow[b]{2}{*}{$\begin{array}{l}\text { Max clam meals } \\
\text { consumed /yr }\end{array}$} & \multicolumn{2}{|c|}{ CLEANED CLAMS $^{1}$} & \multicolumn{2}{|c|}{ WHOLE CLAMS ${ }^{2}$} \\
\hline & & & & & $\begin{array}{c}\text { Min MP } \\
\text { exposure } / y r^{3}\end{array}$ & $\begin{array}{c}\text { Max MP } \\
\text { exposure/yr }\end{array}$ & $\begin{array}{c}\text { Min MP } \\
\text { exposure } / y^{1}\end{array}$ & $\begin{array}{c}\text { Max MP } \\
\text { exposure/yr }\end{array}$ \\
\hline All females & 46 & 3.78 & 4 & 209 & 50 & 2,720 & 100 & 5.330 \\
\hline All males & 59 & 4.81 & 4 & 79 & 70 & 1,310 & 130 & 2.570 \\
\hline All ethnicities combined & 105 & 4.27 & 4 & 209 & 60 & 3.070 & 120 & 6,020 \\
\hline Native American \& Alaska Native & 3 & 7.00 & 20 & 79 & 480 & 1,900 & 950 & 3.730 \\
\hline Non-White/Caucasian & 21 & 3.78 & 4 & 122 & 50 & 1,590 & 100 & 3.110 \\
\hline White/Caucasian & 82 & 4.46 & 4 & 209 & 60 & 3,210 & 120 & 6,290 \\
\hline
\end{tabular}

Notes: "Clam"= Pacific razor clam, Avg= Average, MP= Suspected microplastics, yr= Year, min= minimum, max $=$ maximum; ${ }^{1}=$ Calculated using Avg suspected MP burden of $3.44 \mathrm{MP} / \mathrm{clam},{ }^{2}=$ Calculated using Avg suspected MP burden of $6.75 \mathrm{MP} / \mathrm{clam},{ }^{3}=$ Avg \# clams consumed per sitting $\mathrm{x}$ Avg \# MP/clam x Annual min razor clam meals consumed, ${ }^{4}=$ Avg \# clams consumed per sitting $\mathrm{x}$ Avg \# MP/clam x Annual max razor clam meals consumed.

Of the questionnaire respondents, $16.2 \%(n=17)$ harvested but did not consume razor clams in a given year, but those that did $(83.8 \% ; n=88)$ consumed between 4 and 209 razor clam meals per year (Table 2, Figure 6). Based on minimum and maximum number of razor clam meals per year and average suspected MP burdens in cleaned and whole clams, we estimated the range of MP exposure from razor clams by Olympic Coast harvester-consumers to be $60-3,070 \mathrm{MP} / \mathrm{yr}$ for those that thoroughly clean their clams before consuming them, or $120-6,020 \mathrm{MP} / \mathrm{yr}$ for those that consume clams whole without removing guts, gills or other organs (Table 2). Despite males consuming more clams per 
meal than females, female razor clam harvesters exhibited a broader range of exposure to MP due to higher maximum reported clam consumption than males in winter, summer and fall seasons (Table 2).

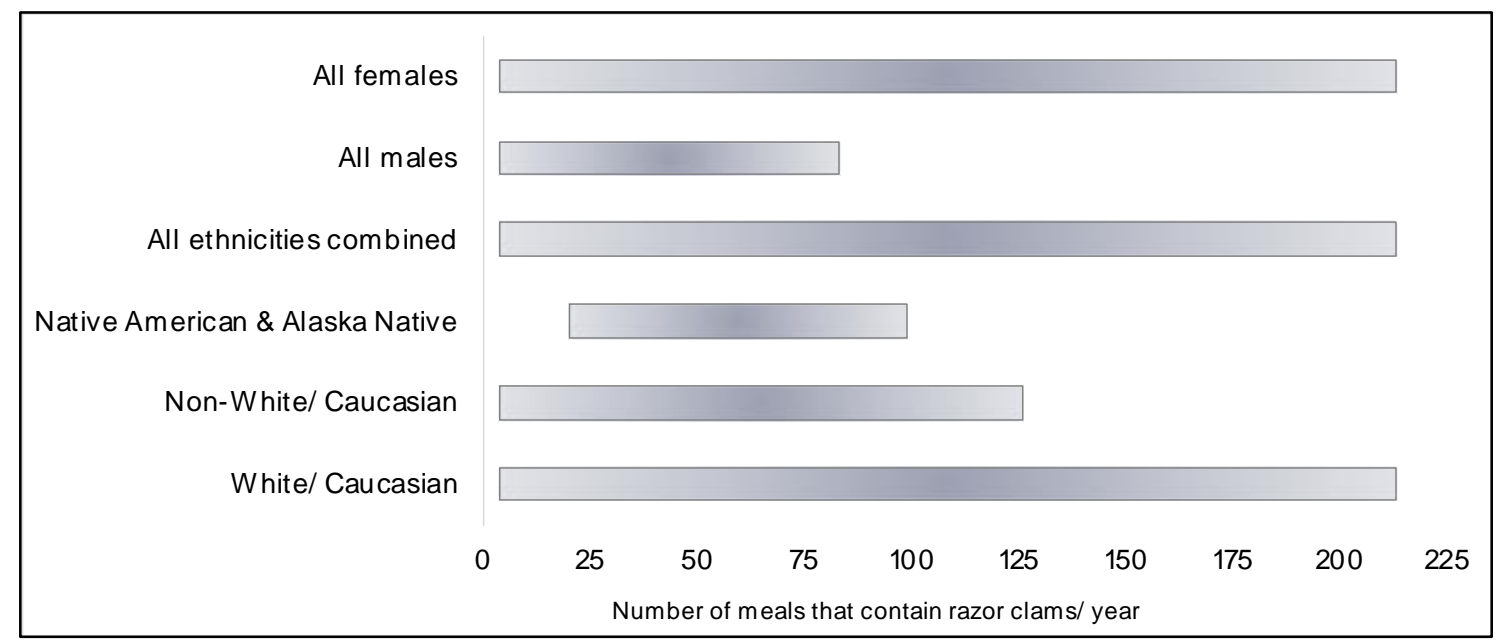

FIGURE 6. Ranges for the number of razor clam meals consumed per year by Olympic Coast harvesterconsumers: Females $(n=46)$, Males $(n=59)$, All ethnicities combined $(n=87)$, Native American \& Alaska Native $(n=3)$, Non-White/Caucasian (includes all ethnicities except White/Caucasian; $n=18$ ), and White/Caucasian $(n=69)$.

Microplastic exposure from razor clam consumption was also broken down by ethnicity into: All (all ethnicities), Native American \& Alaska Native, NonWhite/Caucasian (all other ethnicities excluding White/Caucasian), and White/Caucasian groups (Table 2, Figure 7A-B). The three Native American and Alaska Native respondents in our sample consumed more clams per sitting than other respondents; therefore the minimum exposure to MP through razor clam consumption for this group is higher than for the other ethnicities analyzed (Table 2, Figure 7A-B). 


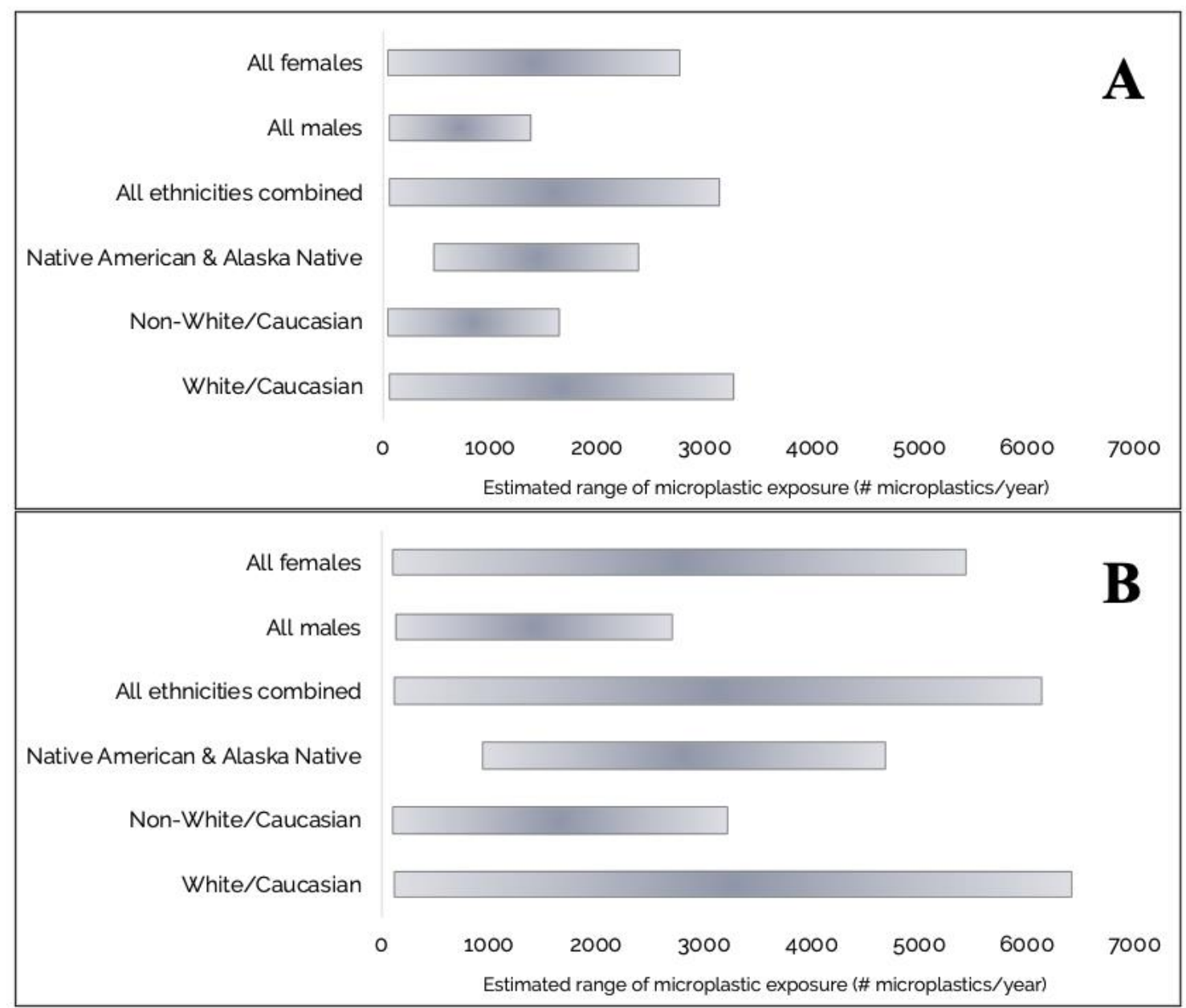

FIGURE 7 (A-B): Ranges of estimated annual Olympic Coast razor clam harvester-consumer microplastic (MP) exposure for: Females $(n=46)$, males $(n=59)$, all ethnicities combined $(n=87)$, Native American \& Alaska Native ( $n=3)$, Non-White/Caucasian $(n=18)$, or White/Caucasian $(n=69)$ respondents from consumption of: (A) Cleaned razor clams with the foot and siphons cleaned and rinsed and the siphon tips, digestive organs and gills removed; and (B) Whole razor clams.

Questionnaire respondent knowledge \& concerns about microplastics in food

When asked "how familiar are you with the concept of microplastics in food?", $64.8 \%(n=68)$ of respondents said they were not familiar, $28.6 \%(n=30)$ said they were moderately familiar, and $6.7 \%(\mathrm{n}=7)$ said they were very familiar. When asked "do you have concerns about microplastics in your food", $41.9 \%(n=44)$ indicated yes, $39.0 \%(n=$ 41) indicated no, and $19.0 \%(\mathrm{n}=20)$ did not know. Twenty-five respondents $(39.0 \%$ of 
those that indicated 'Yes' or 'I don't know' for the question 'do you have concerns about microplastics in your food") answered the open-ended question "Please expand on what concerns you have about microplastics in your food". Concerns recorded were categorized into seven themes: Impacts on humans $(n=6)$, General concern $(n=5)$, Health, chemicals and toxins $(n=4)$, Impacts on humans and the environment $(n=4)$, Uncertainty or unknown $(n=3)$, Impacts on the environment $(n=2)$, and Management $(n=$ 1; Table 3).

TABLE 3. Themes elucidated from Olympic Coast razor clam harvester questionnaire survey responses $(\mathrm{n}=25)$ for the question "Please expand on what concerns you have about microplastics in your food".

\begin{tabular}{|c|c|c|c|c|c|c|}
\hline Impacts on Humans & General Concern & $\begin{array}{l}\text { Health, Chemicals } \\
\text { and Toxins }\end{array}$ & $\begin{array}{l}\text { Impacts on Humans and } \\
\text { the Environment }\end{array}$ & $\begin{array}{l}\text { Uncertainty, } \\
\text { Unknown }\end{array}$ & $\begin{array}{l}\text { Impacts on } \\
\text { Environment }\end{array}$ & Management \\
\hline $\begin{array}{l}\text { Cancer-causing? Do we } \\
\text { need to be worried? Long- } \\
\text { term effects? }\end{array}$ & $\begin{array}{l}\text { Just general } \\
\text { concern }\end{array}$ & Health Hazards & Biomagnification & $\begin{array}{l}\text { Haven't studied } \\
\text { enough to know }\end{array}$ & $\begin{array}{l}\text { Whole } \\
\text { environment } \\
\text { concerns }\end{array}$ & $\begin{array}{l}\text { What they're } \\
\text { going to do } \\
\text { about it }\end{array}$ \\
\hline $\begin{array}{l}\text { Don't want to eat them, } \\
\text { and accumulation }\end{array}$ & Garbage in ocean & General health & Biomagnification & $\begin{array}{l}\text { I don't know } \\
\text { enough }\end{array}$ & $\begin{array}{l}\text { How it affects the } \\
\text { food chain }\end{array}$ & \\
\hline Don't want in food & General presence & $\begin{array}{l}\text { Toxins, health } \\
\text { concerns }\end{array}$ & $\begin{array}{l}\text { Effects on the whole } \\
\text { planet }\end{array}$ & Not sure what it is & & \\
\hline Drinking water & They are out there & Any chemicals & $\begin{array}{l}\text { Health of environment } \\
\text { and humans }\end{array}$ & & & \\
\hline $\begin{array}{l}\text { Not cool with that stuff in } \\
\text { my food, to be honest }\end{array}$ & In water & & & & & \\
\hline $\begin{array}{l}\text { Not something I want to } \\
\text { ingest }\end{array}$ & & & & & & \\
\hline
\end{tabular}

\subsection{Discussion:}

This study confirms MP presence in Olympic Coast Pacific razor clams, a species important to the PNW's coastal ecology, culture, food security, and economy. Razor clams represent not only a traditional but also a critical present-day food source for members of the Quinault Indian Nation and other Olympic Coast peoples. As the 
Olympic Peninsula is sparsely populated relative to other (non-Alaskan) coastal areas in the U.S., this study provides a snapshot of MP prevalence in an area of relatively low human influence. A number of existing studies have found that elevated environmental MP concentrations can be attributed to proximity to dense human population (Barnes et al. 2009; Hantoro et al. 2019); therefore, this study may represent the lower end of human MP exposure from Pacific razor clam consumption in the continental U.S.

The highest $\mathrm{MP} \mathrm{g}^{-1}$ tissue site average was from our northernmost study site, Kalaloch beach (Figure 4B). There are no major rivers near the Kalaloch sample site to deliver large loads of MPs here relative to the other seven sites; however, Kalaloch was the northernmost of our eight sites and is closest in proximity to the highly populated Salish Sea region and at the mouth of Puget Sound. We predicted substantial waterborne MPs would be transported from Puget Sound and the Salish Sea to the Olympic Coast, based on existing hydrographic models (Pirhalla et al. 2009). Proximity of these large water bodies to the Kalaloch site could contribute to its higher-than-average MP concentrations in razor clams. 2010 land cover data for the four coastal Olympic Peninsula counties (Clallam, Jefferson, Grays Harbor, Pacific) show forests are the most dominant land type, followed by scrublands (NOAA 2020; Appendix C: Chapter 3). Development and agriculture represent a small proportion of land use in these counties (Appendix C: Chapter 3) and are likely not the primary dictator of MP burdens in razor clams collected from these sites; therefore, we expect factors other than land use cover are responsible for Kalaloch clams containing significantly more MPs than clams at other sites. Kalaloch clams were the smallest, on average (both shell length and body weight), 
of all eight study sites. While we did not find a correlation between MPs and body size (shell length or body weight) across study sites, clam size may have contributed to high MP $\mathrm{g}^{-1}$ tissue at Kalaloch, as mass-specific filtration can be faster in smaller bivalves relative to their larger counterparts (e.g., Powell et al. 1992; Ehrich and Harris 2015). Average MP burdens per whole razor clam and $\mathrm{g}^{-1}$ tissue in this study fell roughly mid-range compared to MP burdens reported in other bivalves (manila clams, Pacific razor clams, Pacific oysters) throughout the region: the Salish Sea, WA (Martinelli et al. 2020), British Columbia, Canada (Davidson and Dudas 2016; Covernton et al. 2019), and the Oregon coast (Baechler et al. 2020b; Figure 8). It should be noted that these studies employed varying methodologies for MP extraction, identification, and reporting, suggesting the need for caution in interpreting direct comparisons. Methodological variations included differences in digestion chemicals $\left(\mathrm{KOH}, \mathrm{H}_{2} \mathrm{O}_{2}\right)$, microplastic isolation methods (density separation, sieving, vacuum filtration), $\mathrm{MP} \mathrm{g}^{-1}$ tissue calculations (use of wet weight vs dry weight), and validation techniques (none, Raman, or FTIR spectroscopy; Figure 8). 


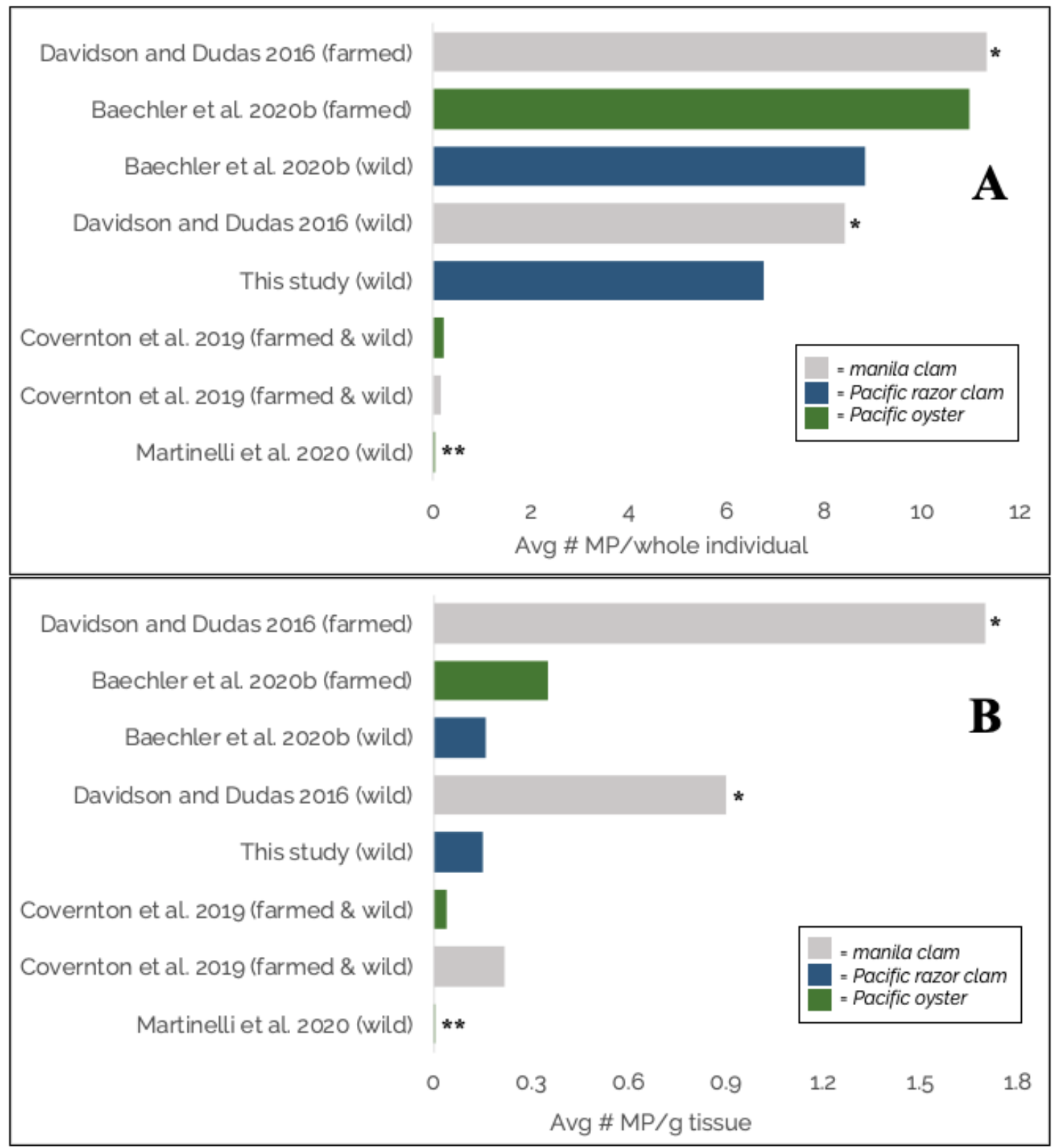

FIGURE 8 (A-B): Comparisons of average microplastic burdens in Pacific Northwest bivalves (Washington and Oregon, U.S. and British Columbia, Canada), in- (A) Average number of microplastics per individual; and (B) Average number of microplastics per gram of tissue (wet weight; except dry weight for Covernton et al. 2019). Gray bars indicate manila clams, blue bars indicate Pacific razor clams, green bars indicate Pacific oysters. Avg= Average, $\mathrm{MP}=$ microplastic, $\mathrm{g}=$ gram. *=All studies except Davidson and Dudas included suspected microplastic material validation using Fourier Transform Infrared (FTIR) or Raman spectroscopy. **= For general context only; calculated from Table 2 of Martinelli et al. (2020) as average of site-specific visually-identified number of particles per oyster (panel A) or per gram of tissue (panel B) for 10 sites $\mathrm{x}$ average site-specific percentage of suspected microplastics confirmed to be plastic through Raman spectroscopy for 10 sites. 
Using FTIR we determined that the randomly-selected suspected MPs analyzed $(n=53)$ were plastic, semi-synthetic, and natural, with $80.77 \%$ confirmed to be either synthetic or semi-synthetic (Kroon et al. 2018; Appendix I: Chapter 3). Polyethylene terephthalate (PET), a member of the polyester family and a widely used thermoplastic polymer resin in clothing and drink containers, was the most commonly identified synthetic material ( $\mathrm{n}=21$; Appendix I: Chapter 3, Appendix J: Chapter 3). PET fibers are ubiquitous in coastal areas globally and are often detected in bivalves (Mishra et al. 2019; Hope et al. 2020). The most commonly identified semi-synthetic fiber was cellulose acetate (n=11; Appendix I: Chapter 3, Appendix J: Chapter 3), a material found in cigarette filters and clothing, that is commonly detected on beaches and in waterways (Miller et al. 2017; Mishra et al. 2019). Cellulose was the lone natural material present in our subsample ( $\mathrm{n}=10$; Appendix I: Chapter 3).

Due to our methodology, the lower size limit of detectable MPs was $63 \mu \mathrm{m}$, though smaller MPs and nanoplastics (NPs; $<1 \mu \mathrm{m}$ ) are known to migrate into the tissues and organs of marine organisms (Lusher et al. 2017). While methodologically, any suspected MPs greater than $63 \mu \mathrm{m}$ in size were included in our samples, the smallest MP we identified was $110 \mu \mathrm{m}$. Therefore, MPs and NPs smaller than $110 \mu \mathrm{m}$ may have been present but undetected in our samples. Additionally, it is unclear if the MPs identified in our whole, cleaned or nongut-tissue samples were incorporated into clams through ingestion or adherence to soft tissues, as both avenues of incorporation have been reported in bivalves (e.g., Xu et al. 2017; Kolandhasamy et al. 2018). 
Combining ecological data on razor clam MP burdens with structured questionnaires allowed us to calculate MP exposure ranges for the Olympic Coast razor clam harvester-consumers surveyed. MP exposure calculations included natural cellulose particles representing $19.23 \%$ of suspected MPs based on FTIR material confirmation results; therefore exposure ranges to MPs may be overestimates. Regardless, our findings suggest the harvester-consumers in this study are likely exposed to low levels of confirmed MPs (relative to other known sources of ingested MPs). Razor clams are unique in that, unlike many other clam and oyster species which are generally consumed whole, they are typically cleaned with parts removed prior to consumption. The Quinault Indian Nation Department of Fisheries suggests the Quinault and other coastal tribal peoples clean razor clams prior to consumption, and the Quinault commercial razor clam processing plant in Taholah similarly cleans clams prior to sale to eliminate guts and gills (Ervin "Joe" Schumacker, Quinault Indian Nation Department of Fisheries, pers. comm. May 1, 2020). While most questionnaire respondents fully cleaned razor clams before consuming them, $11.7 \%$ either consumed the gut or weren't sure if they did. Based on our findings, removal of the gut prior to consumption for this particular species reduces MP burden by nearly $50 \%$ and may be a prudent measure to reduce consumer MP exposure from this particular seafood source. While cleaned clams may substantially reduce MP exposure for human consumers, this approach is not an option for marine razor clam predators.

There are currently no established safety thresholds for human MP intake; however, there are established thresholds for domoic acid in Olympic Coast razor clams. 
Fishery openings and closures have recently been impacted by the presence of domoic acid, a neurotoxin that can cause direct and severe harm to human consumers, including affected memory when consumed in low doses over long periods of time (Chadsey et al. 2012; Grattan et al. 2016; Ferriss et al. 2017; Lefebvre et al. 2017). The Washington Department of Health regularly tests clams for the presence of domoic acid, and closes fisheries when the level meets or exceeds 20 parts per million (ppm; Chadsey et al. 2012; WDFW 2020). In 2016, the state of Washington issued a public health advisory on razor clam consumption, recommending no more than 15 clams be consumed per month, due to the propensity of razor clams to contain low levels of domoic acid below the Department of Health action level of 20ppm (Washington Department of Health 2016).

Microplastics ingested by humans from seafood can be significant in some geographic areas (e.g., Li et al. 2015); however, MP exposure of our study group from razor clam consumption is low relative to other expected exposure routes such as inhalation (estimated maximum of 30,000,000 MP/year; Zhang et al. 2020a), deposition of microfibers during meals (estimated 13,731-68,415 MPs/year; Catarino et al. 2018), consumption of table salt (estimated maximum of 73,000 MPs/year; Zhang et al. 2020a) or drinking bottled water (estimated 90,000 MPs/year; Cox et al. 2019). Our estimates of Olympic Coast razor clam harvester-consumer MP exposure are lower than existing estimates of dietary MPs through bivalve consumption in Europe ( 11,000 MP/year; Van Cauwenberghe \& Janssen 2014) and China ( 110,000 MP/year; Li et al. 2015). This result is expected considering the Olympic Coast is sparsely populated (roughly 12 people $/ \mathrm{km}^{2}$ or 30 people/mile ${ }^{2}$; U.S. Census Bureau 2012) and Southeast Asia and 
Europe support some of the most densely-populated coastal areas in the world $(>10,000$ people $/ \mathrm{km}^{2}$; Nicholls and Small 2002). Moreover, our estimates are for a single species that is frequently cleaned prior to consumption.

Although the vast majority of MPs orally ingested by humans are thought to be excreted (EFSA CONTAM Panel 2016), some proportion of particles may remain in the body. While effects of MPs on human health are not well known, MPs may cause harm due to blockage, release of associated additives, or liberation of sorbed chemicals (Wright and Kelly 2017). Inhaled MPs may become trapped in the lung, purged from the body (i.e., from coughing or sneezing) or, depending on size, enter the digestive tract (Wright and Kelly 2017; Cox et al. 2019). Differential effects from consuming versus inhaling microplastics may be present, though this area is understudied and warrants additional research.

Ferriss et al. (2017) estimated the frequency of razor clam consumption by WA coast recreational razor clam harvesters in 2015-16 at 6.0 clams per day, on days that clams were eaten. Males consumed, on average, more clams/day $(6.5 \pm 0.8)$ than females $(5.4 \pm 0.6)$, with higher overall consumption in the spring than in other seasons (Ferriss et al. 2017). While not directly comparable to our results because we report consumption in number of clams per sitting $(4.27 \pm 0.27)$ instead of per day, the pattern of males consuming more than females, and seasonal clam consumption being highest in spring relative to other seasons are similar. An Olympic Coast razor clam domoic acid study by Grattan et al. (2016), placed those that consume 15 or more razor clams per month in a "high" consumer group, and those that consume fewer than 15 per month into a "low" 
consumer group based on the 2016 WA-recommended consumption limit of 15 clams per month (Washington Department of Health 2016). According to our findings, "high" consumers $(2.67 \%, \mathrm{n}=7$ responses in our study) would then be exposed to a minimum of roughly $600 \mathrm{MP} / \mathrm{yr}$ if thoroughly cleaning 15 clams per month before consuming them, or a minimum of $1,200 \mathrm{MP} / \mathrm{yr}$ if consuming 15 clams per month without cleaning them. Exposure values would increase proportionally with the number of clams consumed per month. Due to the low sample size of Alaska Native and Native American respondents $(n=3)$ in this study, it is not possible to broadly generalize about clam consumption frequencies in either group; however, responses from these few individuals were striking considering the much higher minimum exposure level of MPs through razor clam consumption than other ethnicities, due to a higher minimum number of meals containing razor clams eaten annually and more clams consumed per sitting than other groups. Due to this finding and the knowledge that seafood consumption tendencies vary by ethnicity (e.g. Sechena et al. 1999; Mahaffey et al. 2009; EPA 2014; Cisneros-Montemayor et al. 2016), additional research regarding microplastic exposure from seafood consumption for these and other high-seafood consumer demographics is both warranted and necessary. In conclusion, MP presence in the PNW coastal environment and in food webs, raises concern about potential for ecological harm to Pacific razor clams, their predators, and innumerable other marine species. There is an immense need to reduce future transmission of microplastics, and in particular microfibers, to the marine environment, as these are commonly found in biotic and environmental samples (Barnes et al. 2009; Barboza et al. 2018). A focus on land-based solutions to microplastic pollution is 
imperative, as more than $80 \%$ of primary and secondary microplastics originate on land (Miranda et al. 2019). Apparel washing is a significant vector of synthetic microfibers to the environment; since the 1950's, over 5.9 million metric tons of synthetic microplastics have been generated through laundering (Gavigan et al. 2020). Our findings of primarily microfibers in the guts and tissues of Olympic Coast razor clams highlight the need to develop effective upstream pollution control solutions that capture this type of pollution at the source. One solution to significantly reduce transmission of microfibers into the environment would be the integration of microplastic capture technologies into washing machines. These technologies prevent synthetic microfibers from flowing through household graywater to wastewater treatment plants, where they settle and are frequently extracted along with biosolids and applied to agricultural soils as fertilizer (Mahon et al. 2017; Gavigan et al. 2020). Fiber catchment-integrated washing machines have already been deployed in Japan and, per legislation, will be required in France beginning in 2025 (European Parliament 2020). Broader adoption of similar technologies in the U.S. and around the world could drastically reduce global laundry microfiber emissions in the future.

In conclusion, we identified MPs in razor clams from all of our coastal study sites, highlighting the ubiquity of MPs along the Olympic Coast. The Olympic Coast recreational razor clam harvester-consumers represented in this study were from 14 WA counties and encompassed an array of ethnicities, incomes, education levels, and concerns about the concept of microplastics in food. This work improves understanding of MP prevalence in an important and desirable edible shellfish species. It highlights that 
MPs are present in seafood even in relatively low-impact areas; however, when put into context, this specific seafood item represents a minimal vector of MPs for the recreational razor clam harvester-consumer group studied. Our work serves as an important reference in the growing portfolio of MP research in the PNW to inform future MP attenuation. It can contribute to estimations of overall human MP exposure and could aide in the development of human health standards for this pollution type.

\subsection{Acknowledgments:}

We thank Dr. Kathleen Conn, Dr. Eugene Foster, and Dr. Erin Shortlidge for their extensive and thoughtful input and guidance. Many thanks to Emily Pedersen and Katherine Lasdin of Oregon State University for performing and advising on FTIR analyses, respectively. Thanks to Dr. Angela Strecker and Rich Miller for allowing us the use of their stereomicroscope. Much appreciation to Ervin "Joe" Schumacker, Staci Bruce, and Quinault Indian Nation tribal staff and John Deibert, Clayton Parson, Zach Forster \& WDFW staff, for assistance with sample collection, coordination, and providing input on the manuscript. Thanks to the Applied Coastal Ecology lab for assistance and support throughout the study. Assistance with questionnaire administration was provided by Alex Bienko, Amy Hemingway, Anna Bolm, Scott Holland, and Kaegan Scully-Engelmeyer; sample processing assistance was provided by Scott Holland, Alexandra Tissot, and Rosemary Wood. Funding for this project was provided by the Edward D. \& Olive C. Bushby Scholarship, The Oregon Chapter of the American Fisheries Society, the Sustainable Fisheries Foundation, the Puget Sound Anglers: 
Fidalgo - San Juan Chapter, and the Oregon State University Hatfield Marine Science Center. Publication of this article in an open access journal was funded by the Portland State University Library's Open Access Fund. 


\subsection{Literature Cited:}

Abidli, S., Lahbib, Y., and Trigui El Menif, N. (2019). Microplastics in commercial molluscs from the lagoon of Bizerte (Northern Tunisia). Marine Pollution Bulletin 142, 243-252. doi:10.1016/j.marpolbul.2019.03.048.

Anderson, J. W. (1999). World Is Their Oyster - Interpreting the Scope of Native American Off-Reservation Shellfish Rights in Washington State, The Comment. Seattle U. L. Rev. 23, 145-174.

Anderson, T. L., and Parker, D. P. (2009). Economic development lessons from and for North American Indian economies*. Australian Journal of Agricultural and Resource Economics 53, 105-127. doi:10.1111/j.1467-8489.2007.00426.x.

Avio, C. G., Gorbi, S., Milan, M., Benedetti, M., Fattorini, D., d'Errico, G., et al. (2015). Pollutants bioavailability and toxicological risk from microplastics to marine mussels. Environmental Pollution 198, 211-222. doi:10.1016/j.envpol.2014.12.021.

Baechler, B. R., Stienbarger, C. D., Horn, D. A., Joseph, J., Taylor, A. R., Granek, E. F., et al. (2020a). Microplastic occurrence and effects in commercially harvested North American finfish and shellfish: Current knowledge and future directions. Limnology and Oceanography Letters 5, 113-136. doi:10.1002/lol2.10122.

Baechler, B. R., Granek, E. F., Hunter, M. V., and Conn, K. E. (2020b). Microplastic concentrations in two Oregon bivalve species: Spatial, temporal, and species variability. Limnology and Oceanography Letters 5, 54-65.

doi:10.1002/lol2.10124. 
Barnes, D. K., Galgani, F. , Thompson, R. C., and Morton, B. (2009). Accumulation and fragmentation of plastic debris in global environments. Philosophical Transactions of the Royal Society B: Biological Sciences 364, 1985-1998. doi:10.1098/rstb.2008.0205.

Barboza, L. G. A., Dick Vethaak, A., Lavorante, B. R. B. O., Lundebye, A.-K., and Guilhermino, L. (2018). Marine microplastic debris: An emerging issue for food security, food safety and human health. Marine Pollution Bulletin 133, 336-348. doi:10.1016/j.marpolbul.2018.05.047.

Black, R. W., Barnes, A., Elliot, C., and Lanksbury, J. (2018). Nearshore sediment monitoring for the Stormwater Action Monitoring (SAM) Program, Puget Sound, western Washington. Reston, VA: U.S. Geological Survey doi:10.3133/sir20185076.

Bour, A., Haarr, A., Keiter, S., and Hylland, K. (2018). Environmentally relevant microplastic exposure affects sediment-dwelling bivalves. Environmental Pollution 236, 652-660. doi:10.1016/j.envpol.2018.02.006.

Brander, S. M., Renick, V. C., Foley, M. M., Steele, C., Woo, M., Lusher, A., et al. (2020). EXPRESS: Sampling and QA/QC: A Guide for Scientists Investigating the Occurrence of Microplastics Across Matrices. Appl Spectrosc, 0003702820945713. doi:10.1177/0003702820945713.

Carbery, M., O’Connor, W., and Palanisami, T. (2018). Trophic transfer of microplastics 
and mixed contaminants in the marine food web and implications for human health. Environment International 115, 400-409.

doi:10.1016/j.envint.2018.03.007.

Catarino, A. I., Macchia, V., Sanderson, W. G., Thompson, R. C., and Henry, T. B. (2018). Low levels of microplastics (MP) in wild mussels indicate that MP ingestion by humans is minimal compared to exposure via household fibres fallout during a meal. Environmental Pollution 237, 675-684.

doi:10.1016/j.envpol.2018.02.069.

Chadsey, M., Trainer, V. L., and Leschine, T. M. (2012). Cooperation of Science and Management for Harmful Algal Blooms: Domoic Acid and the Washington Coast Razor Clam Fishery. Coastal Management 40, 33-54. doi:10.1080/08920753.2011.639865.

Charles, B., V. Cooke, E. Grinnell, C. Morganroth III, L. M. Morganroth, M. Peterson, V. R. Hoh, A. Smith, and J. Wray. (2004). When the Tide is Out: An Ethnographic Study of Nearshore Use on the Northern Olympic Peninsula. Native American Traditional and Contemporary Knowledge of the Northern Olympic Peninsula. Coastal Watershed Institute and Olympic National Park. Port Angeles, Washington.

Cho, S.-A., Cho, W.-B., Kim, S.-B., Chung, J.-H., and Kim, H.-J. (2019). Identification of Microplastics in Sea Salts by Raman Microscopy and FT-IR Microscopy. Analytical Science and Technology 32, 243-251. doi:10.5806/AST.2019.32.6.243. 
Cisneros-Montemayor, A. M., Pauly, D., Weatherdon, L. V., and Ota, Y. (2016). A Global Estimate of Seafood Consumption by Coastal Indigenous Peoples. PLoS One 11. doi:10.1371/journal.pone.0166681.

Covernton, G. A., Collicutt, B., Gurney-Smith, H. J., Pearce, C. M., Dower, J. F., Ross, P. S., et al. (2019). Microplastics in bivalves and their habitat in relation to shellfish aquaculture proximity in coastal British Columbia, Canada. Aquaculture Environment Interactions 11, 357-374. doi:10.3354/aei00316.

Cox, K. D., Covernton, G. A., Davies, H. L., Dower, J. F., Juanes, F., and Dudas, S. E. (2019). Human Consumption of Microplastics. Environ. Sci. Technol. 53, 70687074. doi:10.1021/acs.est.9b01517.

Crosman, K., Petrou, E., Rudd, M., and Tillotson, M. (2019). Clam hunger and the changing ocean: characterizing social and ecological risks to the Quinault razor clam fishery using participatory modeling. Ecology and Society 24. doi:10.5751/ES-10928-240216.

Crossett, K, Ache B, Pacheco P, Haber K. (2013). National coastal population report, population trends from 1970 to 2020. NOAA State of the Coast Report Series, US Department of Commerce, Washington.

Davidson, K., and Dudas, S. E. (2016). Microplastic Ingestion by Wild and Cultured Manila Clams (Venerupis philippinarum) from Baynes Sound, British Columbia. Arch Environ Contam Toxicol 71, 147-156. doi:10.1007/s00244-016-0286-4. de Witte, B., Devriese, L., Bekaert, K., Hoffman, S., Vandermeersch, G., Cooreman, K., 
et al. (2014). Quality assessment of the blue mussel (Mytilus edulis): Comparison between commercial and wild types. Marine Pollution Bulletin 85, 146-155. doi:10.1016/j.marpolbu1.2014.06.006.

EFSA Panel on Contaminants in the Food Chain. (2016). Statement on the presence of microplastics and nanoplastics in food, with particular focus on seafood. EFSA Journal 2016 14, 1-30. doi:10.2903/j.efsa.2016.4501

Ehrich, M. K., and Harris, L. A. (2015). A review of existing eastern oyster filtration rate models. Ecological Modelling 297, 201-212. doi:10.1016/j.ecolmodel.2014.11.023.

EPA. (2014). Estimated Fish Consumption Rates for the U.S. Population and Selected Subpopulations (NHANES 2003 - 2010). EPA-820-R-14-002. United States Environmental Protection Agency, Washington, DC, USA. Accessed April 6, 2020 from: https://www.epa.gov/sites/production/files/2015-01/documents/fishconsumption-rates-2014.pdf

Eerkes-Medrano, D., Leslie, H. A., and Quinn, B. (2018). Microplastics in drinking water: A review and assessment of an emerging concern. Current Opinion in Environmental Science \& Health. doi:10.1016/j.coesh.2018.12.001.

European Parliament. (2020). Parliamentary questions: Plastic microfibre filters for new washing machines by 2025. Accessed September 20, 2020 from: https://www.europarl.europa.eu/doceo/document/E-9-2020001371_EN.html\#: :text=France\%20has\%20just\%20adopted\%20a,away\%20fro m\%20clothing\%20during\%20washing. 
Farrell, P., and Nelson, K. (2013). Trophic level transfer of microplastic: Mytilus edulis (L.) to Carcinus maenas (L.). Environmental Pollution 177, 1-3. doi:10.1016/j.envpol.2013.01.046.

Ferriss, B. E., Marcinek, D. J., Ayres, D., Borchert, J., and Lefebvre, K. A. (2017). Acute and chronic dietary exposure to domoic acid in recreational harvesters: A survey of shellfish consumption behavior. Environment International 101, 70-79. doi:10.1016/j.envint.2017.01.006.

Frias, J. P. G. L., and Nash, R. (2019). Microplastics: Finding a consensus on the definition. Marine Pollution Bulletin 138, 145-147. doi:10.1016/j.marpolbul.2018.11.022.

Gavigan, J., T. Kefela, I. Macadam-Somer, S. Suh, and R. Geyer. 2020. Synthetic microfiber emissions to land rival those to waterbodies and are growing. PLOS ONE 15: e0237839. doi:10.1371/journal.pone.0237839

Grattan, L. M., Boushey, C., Tracy, K., Trainer, V. L., Roberts, S. M., Schluterman, N., et al. (2016). The association between razor clam consumption and memory in the CoASTAL cohort. Harmful Algae 57, 20-25. doi:10.1016/j.hal.2016.03.011.

Hantoro, I., Löhr, A. J., Belleghem, F. G. A. J. V., Widianarko, B., and Ragas, A. M. J. (2019). Microplastics in coastal areas and seafood: implications for food safety. Food Additives \& Contaminants: Part A 36, 674-711. doi: $10.1080 / 19440049.2019 .1585581$.

Horn, D., Miller, M., Anderson, S., and Steele, C. (2019). Microplastics are ubiquitous on 
California beaches and enter the coastal food web through consumption by Pacific mole crabs. Marine Pollution Bulletin 139, 231-237.

doi:10.1016/j.marpolbul.2018.12.039.

Hope, J. A., Coco, G., and Thrush, S. F. (2020). Effects of Polyester Microfibers on Microphytobenthos and Sediment-Dwelling Infauna. Environ. Sci. Technol. 54, 7970-7982. doi:10.1021/acs.est.0c00514.

Huppert, D.D., and V.L. Trainer. (2014). Economics of razor clam fishery closures due to harmful algal blooms in Washington State. PICES Scientific Report 47, 59-71.

Kedzierski, M., Lechat, B., Sire, O., Le Maguer, G., Le Tilly, V., and Bruzaud, S. (2020). Microplastic contamination of packaged meat: Occurrence and associated risks. Food Packaging and Shelf Life 24, 100489. doi:10.1016/j.fpsl.2020.100489.

Kim, J.-S., Lee, H.-J., Kim, S.-K., and Kim, H.-J. (2018). Global Pattern of Microplastics (MPs) in Commercial Food-Grade Salts: Sea Salt as an Indicator of Seawater MP Pollution. Environ. Sci. Technol. doi:10.1021/acs.est.8b04180.

Kolandhasamy, P., Su, L., Li, J., Qu, X., Jabeen, K., and Shi, H. (2018). Adherence of microplastics to soft tissue of mussels: A novel way to uptake microplastics beyond ingestion. Science of The Total Environment 610-611, 635-640. doi:10.1016/j.scitotenv.2017.08.053.

Kroon, F. J., Motti, C. E., Jensen, L. H., and Berry, K. L. E. (2018). Classification of marine microdebris: A review and case study on fish from the Great Barrier Reef, Australia. Scientific Reports 8, 16422. doi:10.1038/s41598-018-34590-6.

Kutralam-Muniasamy, G., Pérez-Guevara, F., Elizalde-Martínez, I., and Shruti, V. C. 
(2020). Branded milks - Are they immune from microplastics contamination?

Science of The Total Environment, 136823. doi:10.1016/j.scitotenv.2020.136823.

Lebreton, L. C. M., van der Zwet, J., Damsteeg, J.-W., Slat, B., Andrady, A., and Reisser, J. (2017). River plastic emissions to the world's oceans. Nature Communications 8, 15611. doi:10.1038/ncomms15611.

Lee, H., Kunz, A., Shim, W. J., and Walther, B. A. (2019). Microplastic contamination of table salts from Taiwan, including a global review. Scientific Reports 9, 10145. doi:10.1038/s41598-019-46417-Z.

Lefebvre, K. A., Kendrick, P. S., Ladiges, W., Hiolski, E. M., Ferriss, B. E., Smith, D. R., et al. (2017). Chronic low-level exposure to the common seafood toxin domoic acid causes cognitive deficits in mice. Harmful Algae 64, 20-29. doi: 10.1016/j.hal.2017.03.003.

Lepofsky, D., Smith, N. F., Cardinal, N., Harper, J., Morris, M., Elroy White, G. et al. (2015). Ancient Shellfish Mariculture on the Northwest Coast of North America. American Antiquity 80, 236-259. doi:10.7183/0002-7316.80.2.236.

Li, J., Yang, D., Li, L., Jabeen, K., and Shi, H. (2015). Microplastics in commercial bivalves from China. Environmental Pollution 207, 190-195. doi:10.1016/j.envpol.2015.09.018.

Liebezeit, G., and Liebezeit, E. (2013). Non-pollen particulates in honey and sugar. Food Addit Contam Part A Chem Anal Control Expo Risk Assess 30, 2136-2140. doi: $10.1080 / 19440049.2013 .843025$.

Liebezeit, G., and Liebezeit, E. (2014). Synthetic particles as contaminants in German 
beers. Food Addit Contam Part A Chem Anal Control Expo Risk Assess 31, 15741578. doi:10.1080/19440049.2014.945099.

Link, T. (2000). History and status of Oregon's Pacific razor clam resources. Information Reports 2000-06, Oregon Department of Fish and Wildlife, Marine Resources Program, Astoria, OR: 1-25.

Lusher, A., Hollman, P., and Mendoza-Hill, J. (2017). Microplastics in fisheries and aquaculture: Status of knowledge on their occurrence and implications for aquatic organisms and food safety. FAO Fisheries and Aquaculture Technical Paper; Rome, I,III,IV,V,X,XI,XV,XVI,XVII,1-7,9-35,37-53,55-65,67-69,71-73,75$83,85-123,125-126$.

Mahaffey Kathryn R., Clickner Robert P., and Jeffries Rebecca A. (2009). Adult Women's Blood Mercury Concentrations Vary Regionally in the United States: Association with Patterns of Fish Consumption (NHANES 1999-2004). Environmental Health Perspectives 117, 47-53. doi:10.1289/ehp.11674

Mahon, A. M., B. O’Connell, M. G. Healy, I. O'Connor, R. Officer, R. Nash, and L. Morrison. 2017. Microplastics in Sewage Sludge: Effects of Treatment. Environ. Sci. Technol. 51: 810-818. doi:10.1021/acs.est.6b04048

Martinelli, J. C., Phan, S., Luscombe, C. K., and Padilla-Gamiño, J. L. (2020). Low incidence of microplastic contaminants in Pacific oysters (Crassostrea gigas Thunberg) from the Salish Sea, USA. Science of The Total Environment 715, 136826. doi:10.1016/j.scitotenv.2020.136826.

Mathalon, A., and Hill, P. (2014). Microplastic fibers in the intertidal ecosystem 
surrounding Halifax Harbor, Nova Scotia. Marine Pollution Bulletin 81, 69-79. doi:10.1016/j.marpolbul.2014.02.018.

Miller, R. Z., Watts, A. J. R., Winslow, B. O., Galloway, T. S., and Barrows, A. P. W. (2017). Mountains to the sea: River study of plastic and non-plastic microfiber pollution in the northeast USA. Marine Pollution Bulletin 124, 245-251. doi:10.1016/j.marpolbul.2017.07.028.

Mintenig, S. M., Int-Veen, I., Löder, M. G. J., Primpke, S., and Gerdts, G. (2017). Identification of microplastic in effluents of waste water treatment plants using focal plane array-based micro-Fourier-transform infrared imaging. Water Research 108, 365-372. doi:10.1016/j.watres.2016.11.015.

Miranda, M. N., A. M. T. Silva, and M. F. R. Pereira. 2020. Microplastics in the environment: A DPSIR analysis with focus on the responses. Science of The Total Environment 718: 134968. doi:10.1016/j.scitotenv.2019.134968

Mishra, S., Rath, C. charan, and Das, A. P. (2019). Marine microfiber pollution: A review on present status and future challenges. Marine Pollution Bulletin 140, 188-197. doi:10.1016/j.marpolbul.2019.01.039.

Napper, I. E., and Thompson, R. C. (2016). Release of synthetic microplastic plastic fibres from domestic washing machines: Effects of fabric type and washing conditions. Marine Pollution Bulletin 112, 39-45. doi:10.1016/j.marpolbul.2016.09.025.

Nelms, S. E., Galloway, T. S., Godley, B. J., Jarvis, D. S., and Lindeque, P. K. (2018). 
Investigating microplastic trophic transfer in marine top predators. Environmental Pollution 238, 999-1007. doi:10.1016/j.envpol.2018.02.016.

Nicholls, R. J., and Small, C. (2002). Improved estimates of coastal population and exposure to hazards released. Eos, Transactions American Geophysical Union 83, 301-305. doi:10.1029/2002EO000216.

NOAA. (2020). C-CAP Land Cover Atlas. Office for Coastal Management DigitalCoast website. Accessed September 20, 2020 from: https://coast.noaa.gov/digitalcoast/tools/lca.html.

NOAA Office for Coastal Management. (2020). Fast facts: Economics and Demographics. Accessed April 4, 2020 from: https://coast.noaa.gov/states/fastfacts/economics-and-demographics.html

Olson, R. L. (1936). Quinault Indians. University of Washington Publications in Anthropology 6, 38-39. University of Washington Press.

Phuong, N. N., Poirier, L., Pham, Q. T., Lagarde, F., and Zalouk-Vergnoux, A. (2018). Factors influencing the microplastic contamination of bivalves from the French Atlantic coast: Location, season and/or mode of life? Marine Pollution Bulletin 129, 664-674. doi:10.1016/j.marpolbul.2017.10.054.

Pirhalla D.E., V. Ransibrahmanakul, R. Clark, A. Desch, T. Wynne, and Edwards, M. (2009). An Oceanographic Characterization of the Olympic Coast National Marine Sanctuary and Pacific Northwest: Interpretive Summary of Ocean Climate and Regional Processes Through Satellite Remote Sensing. NOAA Technical Memorandum NOS NCCOS 90. Prepared by NCCOS's Coastal Oceanographic 
Assessments, Status and Trends Division in cooperation with the National Marine Sanctuary Program. Silver Spring, MD, 1-53.

Powell, E.N., Hofmann, E.E., Klinck, J.M., and Ray, S.M. (1992). Modeling oyster populations - A commentary on filtration rate-Is faster always better?: Journal of Shellfish Research, v. 11, 387-398.

Primpke, S., Wirth, M., Lorenz, C., and Gerdts, G. (2018). Reference database design for the automated analysis of microplastic samples based on Fourier transform infrared (FTIR) spectroscopy. Analytical and Bioanalytical Chemistry 410. doi:10.1007/s00216-018-1156-X.

Primpke, S., Christiansen, S., Cowger, W., De Frond, H., Deshpande, A., Fischer, M., et al. (2020). Critical Assessment of Analytical Methods for the Harmonized and Cost-Efficient Analysis of Microplastics. Applied Spectroscopy. doi:10.1177/0003702820921465.

Provencher, J., L. Bond, A., Avery-Gomm, S., B. Borrelle, S., Rebolledo, E. L. B., Hammer, S., et al. (2017). Quantifying ingested debris in marine megafauna: a review and recommendations for standardization. Analytical Methods 9, 14541469. doi:10.1039/C6AY02419J.

Qu, X., Su, L., Li, H., Liang, M., and Shi, H. (2018). Assessing the relationship between the abundance and properties of microplastics in water and in mussels. Science of The Total Environment 621, 679-686. doi:10.1016/j.scitotenv.2017.11.284.

R Core Team. (2020). R: A language and environment for statistical computing. R 
Foundation for Statistical Computing, Vienna, Austria. URL https://www.Rproject.org/.

Ribeiro, F., Garcia, A. R., Pereira, B. P., Fonseca, M., Mestre, N. C., Fonseca, T. G., et al. (2017). Microplastics effects in Scrobicularia plana. Marine Pollution Bulletin 122, 379-391. doi:10.1016/j.marpolbul.2017.06.078.

Rochman, C. M., Tahir, A., Williams, S. L., Baxa, D. V., Lam, R., Miller, J. T., et al. (2015). Anthropogenic debris in seafood: Plastic debris and fibers from textiles in fish and bivalves sold for human consumption. Scientific Reports 5, 14340. doi: $10.1038 /$ srep14340.

Rochman, C. M., Brookson, C., Bikker, J., Djuric, N., Earn, A., Bucci, K., et al. (2019). Rethinking microplastics as a diverse contaminant suite. Environmental Toxicology and Chemistry 38, 703-711. doi:10.1002/etc.4371.

Sechena, R., Nakano, C., Liao, S., Polissar, N., Lorenzana, R., Truong, S., \& Fenske, R. (1999). Asian and Pacific Islander seafood consumption study. EPA Office of Environmental Assessment, 1-169.

Sparks, C. (2020). Microplastics in Mussels Along the Coast of Cape Town, South Africa. Bull Environ Contam Toxicol. doi:10.1007/s00128-020-02809.

Su, L., Cai, H., Kolandhasamy, P., Wu, C., Rochman, C. M., and Shi, H. (2018). Using the Asian clam as an indicator of microplastic pollution in freshwater ecosystems. Environmental Pollution 234, 347-355. doi:10.1016/j.envpol.2017.11.075.

Sussarellu, R., Suquet, M., Thomas, Y., Lambert, C., Fabioux, C., Pernet, M. E. J., et al. 
(2016). Oyster reproduction is affected by exposure to polystyrene microplastics. Proceedings of the National Academy of Sciences 113, 2430-2435. doi:10.1073/pnas.1519019113.

Teng, J., Wang, Q., Ran, W., Wu, D., Liu, Y., Sun, S., et al. (2019). Microplastic in cultured oysters from different coastal areas of China. Science of The Total Environment 653, 1282-1292. doi:10.1016/j.scitotenv.2018.11.057.

Tong, H., Jiang, Q., Hu, X., and Zhong, X. (2020). Occurrence and identification of microplastics in tap water from China. Chemosphere, 126493. doi:10.1016/j.chemosphere.2020.126493.

Toussaint, B., Raffael, B., Angers-Loustau, A., Gilliland, D., Kestens, V., Petrillo, M., et al. (2019). Review of micro- and nanoplastic contamination in the food chain. Food Additives \& Contaminants: Part A 36, 639-673. doi:10.1080/19440049.2019.1583381.

U.S. Census Bureau. (2012). Washington: 2010 Population and Housing Unit Counts. 2010 Census of Population and Housing. Accessed April 8, 2020 from: https://www2.census.gov/library/publications/decennial/2010/cph-2/cph-2-49.pdf Van Cauwenberghe, L., and Janssen, C. R. (2014). Microplastics in bivalves cultured for human consumption. Environmental Pollution 193, 65-70. doi:10.1016/j.envpol.2014.06.010. von Moos, N., Burkhardt-Holm, P., and Köhler, A. (2012). Uptake and Effects of 
Microplastics on Cells and Tissue of the Blue Mussel Mytilus edulis L. after an Experimental Exposure. Environ. Sci. Technol. 46, 11327-11335. doi:10.1021/es302332w.

Washington Department of Health. (2016). Domoic Acid in Razor Clams: Interim Health Advisory on Eating Razor Clams. Accessed April 6, 2020 from: https://www.doh.wa.gov/CommunityandEnvironment/Shellfish/RecreationalShell fish/Illnesses/Biotoxins/DomoicAcidinRazorClams.

WDFW. (2019). Washington razor clam management: Setting the 2019-20 season. Accessed Feb 11, 2020 from: https://wdfw.wa.gov/sites/default/files/publications/02104/wdfw02104.pdf. WDFW. (2020). Latest Domoic Acid Levels. Accessed April 15, 2020 from: https://wdfw.wa.gov/fishing/basics/domoic-acid/levels.

Woods, M. N., Stack, M. E., Fields, D. M., Shaw, S. D., and Matrai, P. A. (2018). Microplastic fiber uptake, ingestion, and egestion rates in the blue mussel (Mytilus edulis). Marine Pollution Bulletin 137, 638-645. doi:10.1016/j.marpolbu1.2018.10.061.

Wright, S. L., and Kelly, F. J. (2017). Plastic and Human Health: A Micro Issue? Environ. Sci. Technol. 51, 6634-6647. doi:10.1021/acs.est.7b00423.

Wyer, H. (2013). Pacific Razor clam Siliqua patula. Monterey Bay Aquarium Seafood Watch. Monterey, California, USA.

Xu, X.-Y., Lee, W. T., Chan, A. K. Y., Lo, H. S., Shin, P. K. S., and Cheung, S. G. 
(2017). Microplastic ingestion reduces energy intake in the clam Atactodea striata. Marine Pollution Bulletin 124, 798-802.

doi:10.1016/j.marpolbul.2016.12.027.

Zhang, H. (2017). Transport of microplastics in coastal seas. Estuarine, Coastal and Shelf Science 199. doi:10.1016/j.ecss.2017.09.032.

Zhang, Q., Xu, E. G., Li, J., Chen, Q., Ma, L., Zeng, E. Y., et al. (2020a). A Review of Microplastics in Table salt, Drinking Water, and Air: Direct Human Exposure. Environ. Sci. Technol. doi:10.1021/acs.est.9b04535.

Zhang, Y., Kang, S., Allen, S., Allen, D., Gao, T., and Sillanpää, M. (2020b). Atmospheric microplastics: A review on current status and perspectives. EarthScience Reviews 203, 103118. doi:10.1016/j.earscirev.2020.103118. 


\section{Chapter 4: Aquarium Visitor Engagement with an Ocean Plastic Exhibit: Effects on Self-Reported Single-Use Plastic Reductions and Plastic-Related Environmental Stewardship Actions}

Special note: This manuscript was first submitted to the journal Environmental Education Research in Oct. 2020 and is currently in review.

\subsection{Introduction:}

Plastic is one of the most heavily relied-upon materials used by humans today. Derived from petroleum, plastics are lightweight, durable, inexpensive, and versatile (Andrady 2011; Cole et al. 2011; Eriksen et al. 2014; Auta et al. 2017). From food wrappers and drink containers, to bottles for cleaners and personal products, electronics, textiles, furniture, vehicles, and building components, plastics are integrated into every facet of our existence. Large-scale plastic production began in the 1950's, has increased exponentially since, and will likely continue along this trajectory in the coming decades (Napper and Thompson 2020). Plastics have many important uses and benefits; however, overproduction and mismanagement have led to a plastic pollution problem which has escalated into a pervasive environmental crisis (Barnes et al. 2009; Jambeck et al. 2015; Vince and Stoett 2018).

It is estimated that in 2016, up to 23 million metric tons of plastic waste entered the aquatic environment worldwide (Borelle et al. 2020). A growing body of literature supports the thesis that environmental plastics pose more than just aesthetic harm; they impact human communities (Phelan et al. 2020) and are regularly encountered by wildlife, causing direct harm through entanglement or ingestion (Kühn et al. 2015). As 
plastics permeate the environment, the need to reduce our plastic dependencyparticularly on problematic single-use items- grows more pressing. Unfortunately, there are no simple solutions. Instead, multifaceted approaches including reductions in plastic production, improved waste management, transitioning to a more circular economy, and increasing the scale of environmental recovery are all needed (Veiga et al. 2016; Lau et al. 2020; Borelle et al. 2020). While regulatory actions, infrastructure improvements and interventions such as capture devices and cleanups are critical tools with substantial potential to help tackle this global issue (e.g., Hohn et al. 2020; Lau et al. 2020), reducing individual-level consumption of problematic single-use plastic items is another essential component of the solution as individual actions influence the global waste stream. Individual behavioral shifts replacing single-use plastic items with reusable alternatives can collectively help diminish plastic waste and leakage into the environment (Schnurr et al. 2018). Consumer behaviors leading to plastic pollution that cause environmental degradation are often unintentional; thus, there is immense possibility to promote habits and create positive, long-term behavioral change through education (Knussen and Yule 2008; Ohtomo and Ohnuma 2014; Pahl and Wyles 2017).

As is documented in the literature, sustainability-related behavioral shifts can be difficult to elicit, but effective education and outreach campaigns can empower people and ultimately turn the desired behaviors into actions (e.g., Chase et al. 2009; Leisher et al. 2012; Korkala et al. 2014; Sujata et al. 2019; Napper and Thompson 2020). While environmental stewardship and sustainability topics can and should be approached in the classroom, informal learning is a powerful way to disseminate information to broad 
audiences. Aquaria and zoos provide excellent opportunities for visitor empowerment and education with respect to natural history, living organisms, and environmental issues. Educational exhibits and programs at these types of facilities stimulate conservation interest, awareness, enthusiasm and advocacy (Falk and Adelman 2003; Briseño-Garzón et al. 2007; Jensen et al. 2017). Visitors flock to aquaria and zoos to spend time with family and friends, satisfy their curiosity, experience a fun outlet for intellectual stimulation, and challenge their existing knowledge (Falk and Adelman 2003; Johnson and Kubarek 2019). Over 200 million people visit Association of Zoos and Aquariums facilities around the globe annually, with U.S. facilities hosting roughly 183 million people each year (Association of Zoos \& Aquariums 2020). Families or family groups typically represent over half of all visitors to zoos and aquaria (Diamond 1986; Blud 1990; Briseño-Garzón et al. 2007); these visits help families build values, interests, and a collective family identity (Ellenbogen et al. 2004).

Exhibits and programming encountered in informal learning settings can leave lasting impressions and influence long-term behaviors, particularly when relevant to visitors' prior knowledge or experience, communication materials are clearly and convincingly written, the conservation goals are linked to everyday actions, and examples of how to achieve the actions are presented (Ballantyne et al. 2007). Positive effects from visits to zoos and aquaria have been shown to persist for years post-visit (Jensen et al. 2017). In particular, exhibits and displays that offer interactive elements can be highly impactful, as they stimulate learning and increase understanding of the topic at hand (Cohen 1987). 
Studying human behavior is important to inform education and outreach strategies and effective approaches for environmental problem solving (Pahl and Wyles 2017). Analyzing the amount of time visitors spend at an exhibit, how they engage with different exhibit elements, and determining what they like and dislike about the exhibit, can help guide exhibit designs that effectively engage and inform diverse audiences. One quantitative method to determine how well an exhibit holds a visitor's attention is by recording the amount of time spent in the exhibit. Other measures to quantify engagement with exhibits (e.g., number of hands-on interactions, number of glances) can be used as complimentary proxies for visitor interest in the exhibit and specific exhibit elements.

We designed and installed an exhibit at the Oregon Coast Aquarium (OCA), located in Newport, Oregon to educate visitors about ocean plastic pollution. The exhibit featured written information in panel format and hands-on learning opportunities regarding ocean plastic prevalence, sources to the environment, types of plastic materials, ways marine organisms are affected by microplastics, and how individuals can reduce plastic transmission into the environment. Plain language was used wherever possible to avoid scientific jargon, which can hinder understanding of scientific concepts and generate distrust in the concepts presented (Bullock et al. 2019; Shulman et al. 2020).

To assess exhibit engagement, visitor knowledge about ocean plastic, learning outcomes, exhibit strengths and potential areas of improvement, and to evaluate existing and intended single-use plastic actions of OCA visitors, we asked the following research questions:

\section{How does engagement differ between interactive and visual exhibit elements and by visitor gender, age, and exhibit crowding level?}


2. What baseline knowledge do visitors possess about ocean plastic, and did this exhibit facilitate new learning?

3. Did the exhibit generate an intent to change behaviors including singleuse plastic reduction or plastic stewardship actions and did this vary by demographic (gender, age, zip code)?

4. What do visitors (and their children, if applicable) like most about the exhibit, and how can it be improved?

For question 1, we hypothesized interactive elements would foster greater engagement from children (0-17 years) than adults (18-80+ years), and visual elements would foster greater engagement from adults than children. We predicted visitors would spend more time in the exhibit during the less crowded (November) than the more crowded (August) season, but it would not differ by gender. For questions 2 and 3, we hypothesized: 1) Visitors would have some baseline knowledge about the ocean plastic problem, considering OCA visitors have previously prioritized plastic pollution as a conservation problem (Johnson and Kubarek 2019), and aquarium visitors tend to have higher-than-expected competency about basic environmental concepts when compared to other groups (Reinhard et al. 2007); 2) Visitors would garner new information from the exhibit; and 3) Plastic use behavior changes would differ by age, residence in states with marine coastlines, and in Oregon residents vs non-Oregonians.

\title{
4.2 Materials \& Methods- Study site, exhibit design and evaluation:
}

\author{
Oregon Coast Aquarium (OCA)
}


The OCA, a nonprofit organization located in Newport, Oregon, hosts over 420,000 visitors annually (Kerry Carlin-Morgan, personal communication August 2020). The Aquarium's mission is to "create unique and engaging experiences that connect you to the Oregon Coast and inspire ocean conservation”. In a 2019 study by Johnson and Kubareck, 260 OCA visitors were given a list of important conservation issues to prioritize including plastic pollution, climate change, ocean acidification, sustainable fisheries and illegal wildlife. OCA visitors listed addressing plastic pollution as the top conservation priority. OCA's existing educational programming highlights ocean plastic pollution and how individuals can help combat the issue. At the time of installation on March 15, 2019, the only other ocean plastic-themed exhibit at OCA was an art piece displaying marine debris collected during a 2-hour cleanup on an Oregon beach.

\section{Exhibit design}

Our ocean plastic exhibit consisted of four informational wall panels, three interactive exhibit enhancements mounted on wooden box stands, and a hanging art installation (Figures $1 \&$ 2, Table 1, Appendix K: Chapter 4, Appendix L: Chapter 4). Editable electronic versions of the signs, exhibits, and products created for this exhibit are available as supplemental materials and can be adapted for future use. 


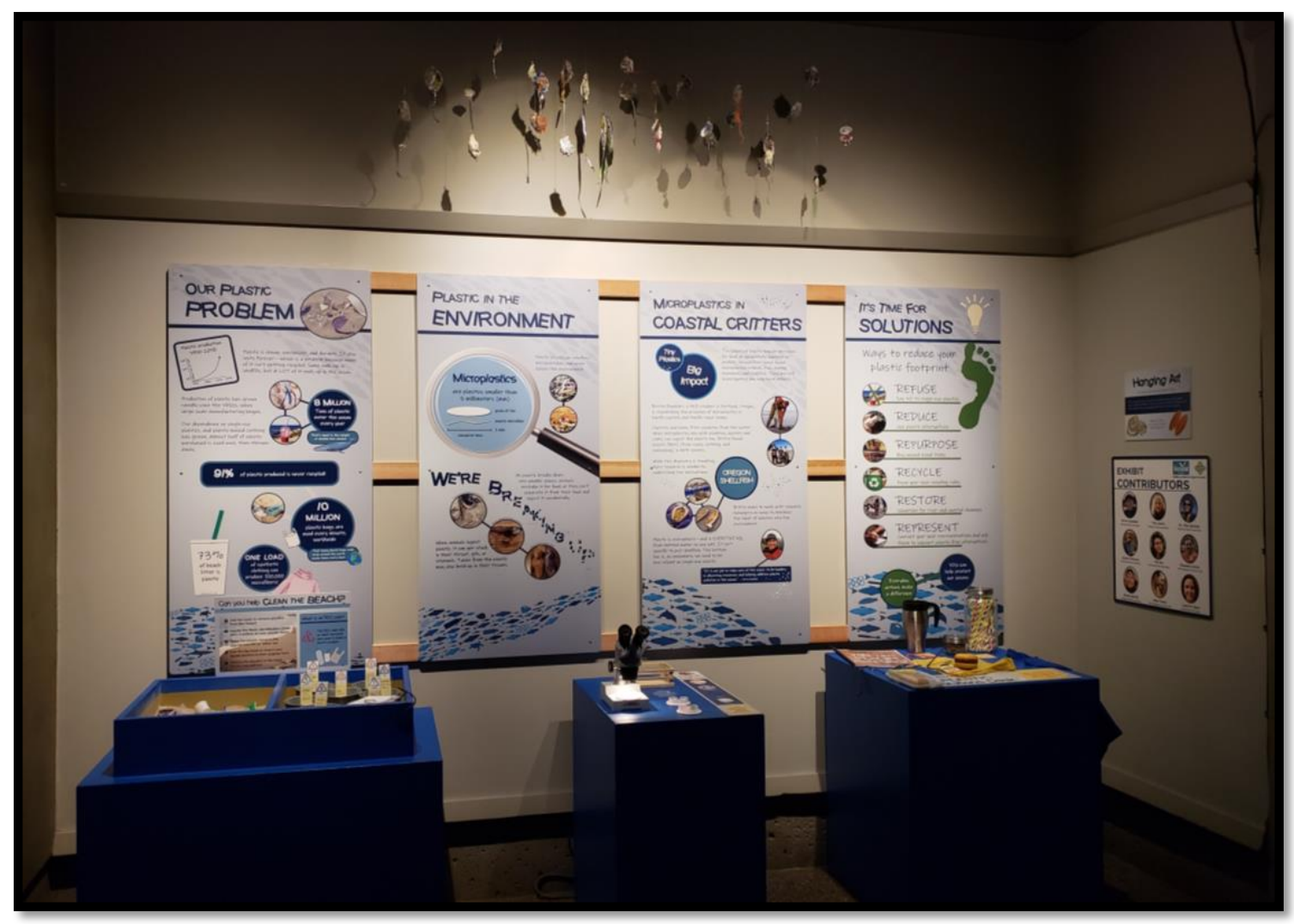

FIGURE 1. Photo of the ocean plastic exhibit displayed at the Oregon Coast Aquarium (OCA) in Newport, Oregon, U.S. from March 2019-April 2020. 


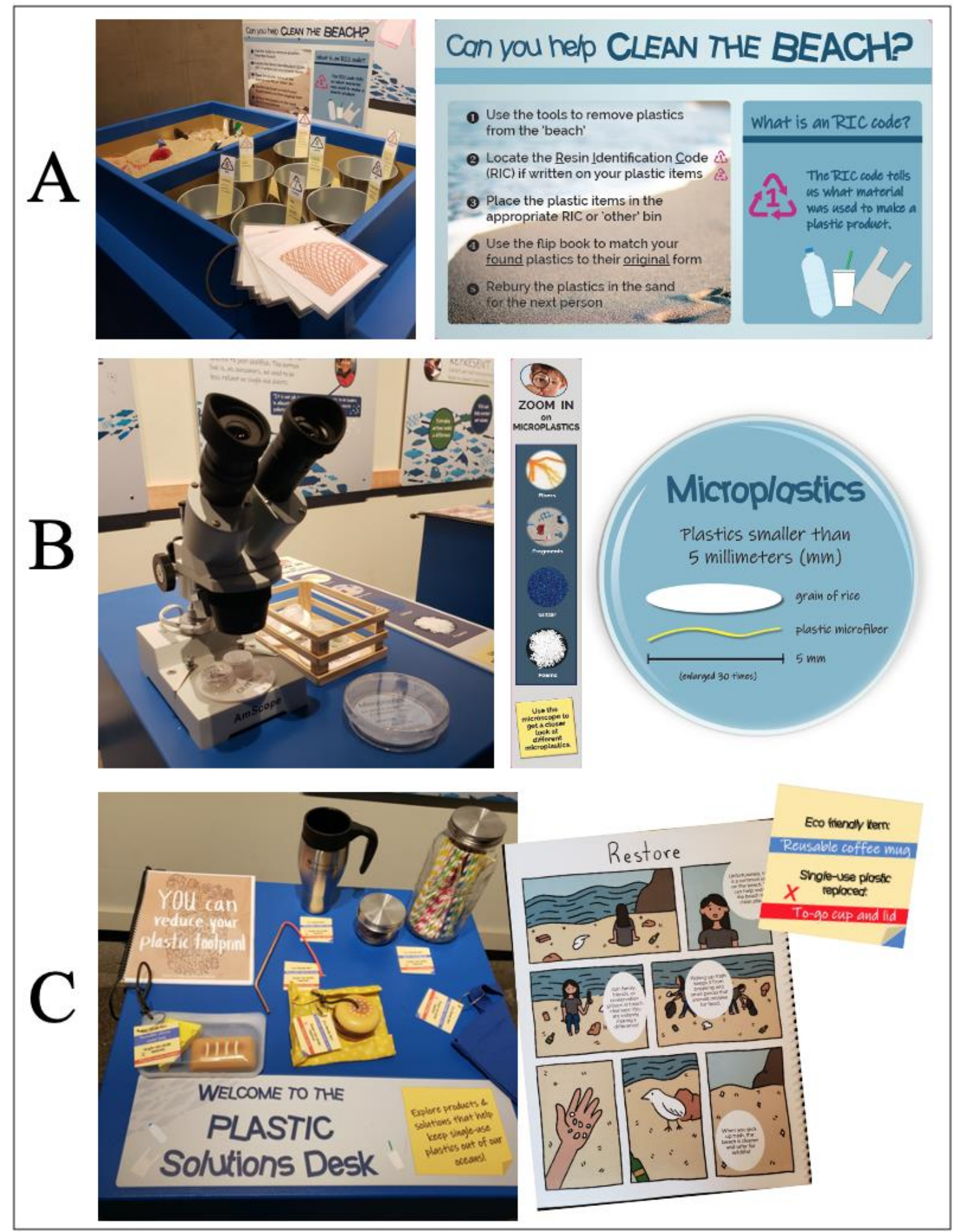

FIGURE 2 (A-C): Layout and content of the three ocean plastic exhibit interactive podia: A) Can You Help Clean the Beach? B) Zoom in on Microplastics, and C) Plastic Solutions Desk. 
TABLE 1. Descriptions of ocean plastic exhibit informational panels, interactive elements, and art installation.

INFORMATIONAL PANELS

Panel 1: Our plastic problem Introduced the plastic problem, using global numbers of plastic prevalence use and leakage into the environment, Ex: "8 million tons of plastic enter the oceans each year. That's equal to the weight of 40,000 blue whales!"

Panel 2: Plastic in the Environment

Described how large pieces of plastic break up into microplastics, defined microplastics, and introduced the concept that marine organisms often mistake microplastics for food items

Panel 3: Microplastics in coastal critters

Provided information on Oregon-specific microplastics research investigating plastic prevalence in two edible Oregon bivalve species.
INTERACTIVE ELEMENTS Clean the beach

Included a divided sandbox mounted to a wooden box stand with a variety of plastic items buried in the sand, and a laminated flipbook. On each page of the flipbook were pictures of a fragment or piece of an everyday plastic item found on the table, and on the back were zoomed-out versions of those plastic items with the Resin Identification Code (RIC) codes noted. Each plastic item had a visible RIC code that visitors matched up to the plastic item it originated from. Directions included a short description and definition of RIC codes and instructions to: 1) Use tools to remove plastics from the 'beach'; 2) Locate the Resin Identification Code (RIC) on your plastic items; 3) Place your plastic items in appropriate RIC bins; 4) Use the flip book to match your found plastics to their original form; and 5) Reset for the next person: re- bury plastics in the sand.

Zoom in on microplastics

Featured an adjustable dissecting microscope and two handheld magnifying glasses mounted to a wooden box stand. Photo

descriptions of different microplastic types (fragments, foams, glitter, fibers) were listed on the interpretive panel next to the microscope. Samples of each microplastic type were available in small acrylic jars for observation under the microscope or with magnifying glasses. The instructions explained to visitors: "Peer through the microscope to discover what different types of microplastics look like up close!".

Po

Featured a variety of alternatives to single-use plastic household items mounted to a wooden box stand, including glass mason jars for food storage, paper and metal straws, canvas tote bags, beeswax food wrap (and wooden food items to practice using the wrap), silicone food storage bags, insulated metal beverage mugs, and a cartoon booklet depicting plasticreducing behaviors. Each plastic alternative was labeled with a tag identifying the plasticfree item and the single-use plastic item it could replace.

ART INSTALLATION
$\frac{\text { Hanging shell art }}{\text { The piece was fabricated from a variety of }}$
locally-collected bivalve shells, resin, plastic
pieces, and marine fishing line as an artistic
interpretation of the global plastic pollution
problem by Hanna Gentile and Anna Young. It
was hung directly above the marine plastics
display out of reach from museum visitors due

to its fragile nature. 
To answer our first research question, we conducted timed interaction surveys to determine which exhibit elements were most and least successful at engaging visitors. To answer the second and third research questions, we administered a structured questionnaire to randomly-selected adults (18+ years) to determine if visitors were taking away the main messages of the exhibit, quantify changes to respondent interest in helping tackle the ocean plastic pollution problem, and document intended reductions in singleuse plastic or plastic stewardship actions. Exhibit evaluation occurred over eight days during August and November 2019. All evaluation methods and questionnaire items were approved by Portland State University (PSU)'s Human Research Protection Program, Office of Research Integrity Internal Review Board (IRB) protocol \# 196534-18. Timed interaction surveys and structured questionnaires were administered 11:00am-3:59pm on weekdays and weekends to control for possible time-of-day or day-of-week visitor differences (Appendix L: Chapter 4, Appendix N: Chapter 4). August represented the high-traffic season and November the low-traffic season. Questionnaires were developed with input from previous OCA exhibit summative assessments and surveys (Kathryn Owen Consulting 2015; Nalven 2019).

\section{Timed interaction surveys}

Timed interaction surveys assessed engagement with interactive and visual exhibit elements, by quantifying total time spent in the immediate exhibit area and number of times each exhibit element was read or physically touched (Appendix P: Chapter 4). Visitors were randomly selected for observations as they entered the exhibit (Appendix K: Chapter 4, Appendix N: Chapter 4). Timed interactions began at the top of 
the hour between 11:00am-3:59pm, with up to 10 individuals timed per hour. Interactions of every third individual entering the exhibit space were timed during the August (high-traffic) survey, and those from every other individual timed during the November (low-traffic) survey. Time spent was recorded as the number of seconds in the exhibit space; timing began when the individual entered the exhibit space (crossed the imaginary exhibit entrance line; Appendix K: Chapter 4) and ended when they turned away. In instances where an individual turned away from the exhibit, exited the exhibit area, and returned, the time spent after returning was not added to the original time spent. Visitors that did not at least glance at the exhibit while walking through the exhibit area were not included in the survey. Researchers estimated visitor age ranges $(0-5,6-10,11-$ 17, 18-29, 30s, 40s, 50s, 60s, 70s, 80+) and genders (Male, Female, Unknown; Appendix P: Chapter 4). Timed interaction data were collected unobtrusively by one or two surveyors obscured from view at the surveyor post (Appendix K: Chapter 4, Appendix P: Chapter 4).

\section{Structured questionnaires}

Structured questionnaires with mixed question types (Yes/No/I don't know, Likert scale, Single-word response, Open-ended short-answer response) measured immediate impacts of the exhibit experience by assessing if visitors learned from the information presented in this exhibit, what they (and their children, if applicable) liked most about the exhibit, how they thought the exhibit could be improved, and which of 10 single-use plastic reduction or plastic stewardship actions they participate (or intend to participate) in. Questionnaires were administered to adult visitors that spent at least 30 seconds 
engaging with the exhibit (Appendix K, M, O: Chapter 4). Individuals appearing younger than 16 years old and those who did not engage with the exhibit for 30 seconds or more were not asked to complete a questionnaire. The 30 second cutoff was determined by questionnaire survey administrators to be the approximate minimum number amount of time needed for a visitor to sufficiently view all four exhibit panels and interactive elements. The surveyor stood at the surveyor post obscured from view (Appendix K: Chapter 4). As target individuals began to turn away from the exhibit, the surveyor approached them, briefly described the project and asked for their consent to complete the questionnaire. An initial set of questions about exhibit perceptions, visitor knowledge about ocean plastic, and learning from the exhibit were posed orally, with the questionnaire administrator recording answers (Appendix N: Chapter 4; survey pages 12). The second set of questions about existing single-use plastic behaviors, intent to change behaviors and demographics (gender, age, zip code) were written in by respondents (Appendix N: Chapter 4; survey pages 3-4). After reporting frequency of the 10 single-use plastic reduction or plastic stewardship actions they currently participate in on a scale of $0-4(0=$ Never; $1=$ Rarely-I have done this a couple of times; $2=$ Sometimesabout once or twice a week; $3=$ Frequently-three or more days a week; $4=$ Almost every day), respondents were asked to revisit the actions and place a single star next to actions they "probably will start doing or increase" after seeing the exhibit, two stars next to the actions they "definitely will start doing or increase" after seeing the exhibit, or no stars if they did not anticipate changing their activity level for that action after seeing the exhibit.

Data analysis and coding 
Data were plotted using Microsoft Excel and R studio statistical package (R Core Team 2020). ANOVA, post-hoc Tukey tests, and Welch's T-tests were run using the .aov, tukey.test and t.test functions in R studio to identify statistically significant differences among groups (alpha $=0.05)$. Standard errors $(S E)$ were reported with averages. Timed interaction survey data were analyzed by demographic (age and gender) and temporal (season, day of week) factors. Structured questionnaire data were analyzed according to the variables of respondent age, gender and zip code. Mean, median and mode values were calculated for each of the 10 single-use plastic reduction or plastic stewardship actions (Appendix S: Chapter 4). Open-ended questionnaire responses (Questions 3, 5, 6, 7, 9A, 10, 13, and 14; Appendix N: Chapter 4) were coded thematically by the Applied Coastal Ecology (ACE) lab group at Portland State University. The ACE group determined response themes and binned them accordingly. Each single-word response (Questions 13 and 14; Appendix N: Chapter 4) was binned into a single theme, but each short-answer response (Questions 3, 5, 6, 7, 9A, 10; Appendix N: Chapter 4) could be placed into more than one category if multiple themes were elicited. ACE thematic categorizations were reviewed by the paper's lead author and reorganized if necessary. Final categorizations were determined by the lead author. Percent agreement scores between the ACE lab and lead author were generated for each question based on categorization before and after final lead author determination, to quantitatively determine the extent to which the lead author's categorizations aligned with categorizations of other ACE scientists (Appendix Q: Chapter 4). 


\subsection{Results:}

\section{Timed interaction survey}

A total of 317 timed interactions were recorded in August $(n=170)$ and November $2019(n=147)$, and included females $(n=169)$ and males $(n=148)$ in age groups ranging from $0-5$ (youngest; $n=38$ ), to $80+$ years (oldest; $n=3$ ). Wall panels were read 411 total times, sometimes multiple times per individual. All four panels were read roughly equivalently, with Panel 1 (Our plastic problem) garnering 105 total reads, Panel 4 (It's Time for Solutions) garnering 100 reads, Panel 3 (Microplastics in Coastal Critters) with 99 reads and Panel 2 (Plastic in the Environment) with 96 reads. If using total number of touches as a proxy for interest in the exhibit elements, the Zoom in on Microplastics stand garnered the most interest $(\mathrm{n}=1,118$ total touches), followed by Can You Help Clean the Beach? ( $\mathrm{n}=800$ total touches) and the Plastic Solutions Desk $(\mathrm{n}=383$ total touches).

Time and interaction differences by age, gender, and crowding level

Children aged 6-10 spent, on average, significantly more time in the exhibit than all other age groups $\left(168.56 \pm 4.33\right.$ seconds; $\left.\mathrm{F}_{9,306}=6.302, \mathrm{p}<0.0001\right)$, with children aged 0-5 spending the second highest amount of time in the exhibit $(107.63 \pm 4.03$ seconds; Figure 3A). There was not a significant gender difference in time spent in the exhibit, as females spent an average of $93.75 \pm 7.98$ seconds and males spent $81.19 \pm 7.80$ seconds $(\mathrm{T}=1.050, \mathrm{p}=0.295)$. Visitors spent more, but not significantly more, time in the exhibit space in November (avg= $96.48 \pm 7.05$ seconds), when the aquarium was less crowded, 
than in August (avg= 80.44 \pm 8.89 seconds; $\mathrm{T}=-1.41, \mathrm{p}=0.159)$. Similarly, visitors spent more (but not significantly more) time in the exhibit space on Mondays (avg=109.75 \pm 15.51 seconds) than other survey days (Thursdays, Fridays, Saturdays, Sundays; avg= $87.88 \pm 5.60$ seconds; $\mathrm{F}_{4.312}=1.070, \mathrm{p}=0.372$ ).

When interaction types (reading, touching) were analyzed by age group (Figure 3C) and quantified by the number of times any interactive components were touched, visitors in the two oldest age groups (70s or $80+$ ) read wall panels more frequently than all other age groups $\left(\mathrm{F}_{9,307}=14.790, \mathrm{p}<0.0001\right.$; Figure $\left.3 \mathrm{~B}\right)$, and visitors in the two youngest age groups (0-5 and 6-10) touched the three interactive exhibit elements more frequently than all other age groups $\left(\mathrm{F}_{9,307}=9.925, \mathrm{p}<0.0001\right.$; Figure $\left.3 \mathrm{C}\right)$. Females interacted with the Can You Help Clean the Beach? table marginally more than males (females: $\mathrm{avg}=3.11 \pm 0.63, \mathrm{n}=523$ touches; males: $\mathrm{avg}=1.91 \pm 0.35, \mathrm{n}=277$ touches; $\mathrm{T}=$ $1.678, \mathrm{p}=0.094)$. Average number of Zoom in on microplastics table interactions did not differ by gender (females: $a v g=3.83 \pm 0.51, n=636$ touches; males: $a v g=3.44 \pm 0.73, n=$ 482 touches; $\mathrm{T}=0.553, \mathrm{p}=0.580$ ), nor did interactions with the Plastic Solutions Desk (females: $\operatorname{avg}=1.26 \pm 0.18, \mathrm{n}=212$ touches; males: $\mathrm{avg}=1.16 \pm 0.18, \mathrm{n}=171$ touches; $\mathrm{T}=$ $0.321, \mathrm{p}=0.749)$. 


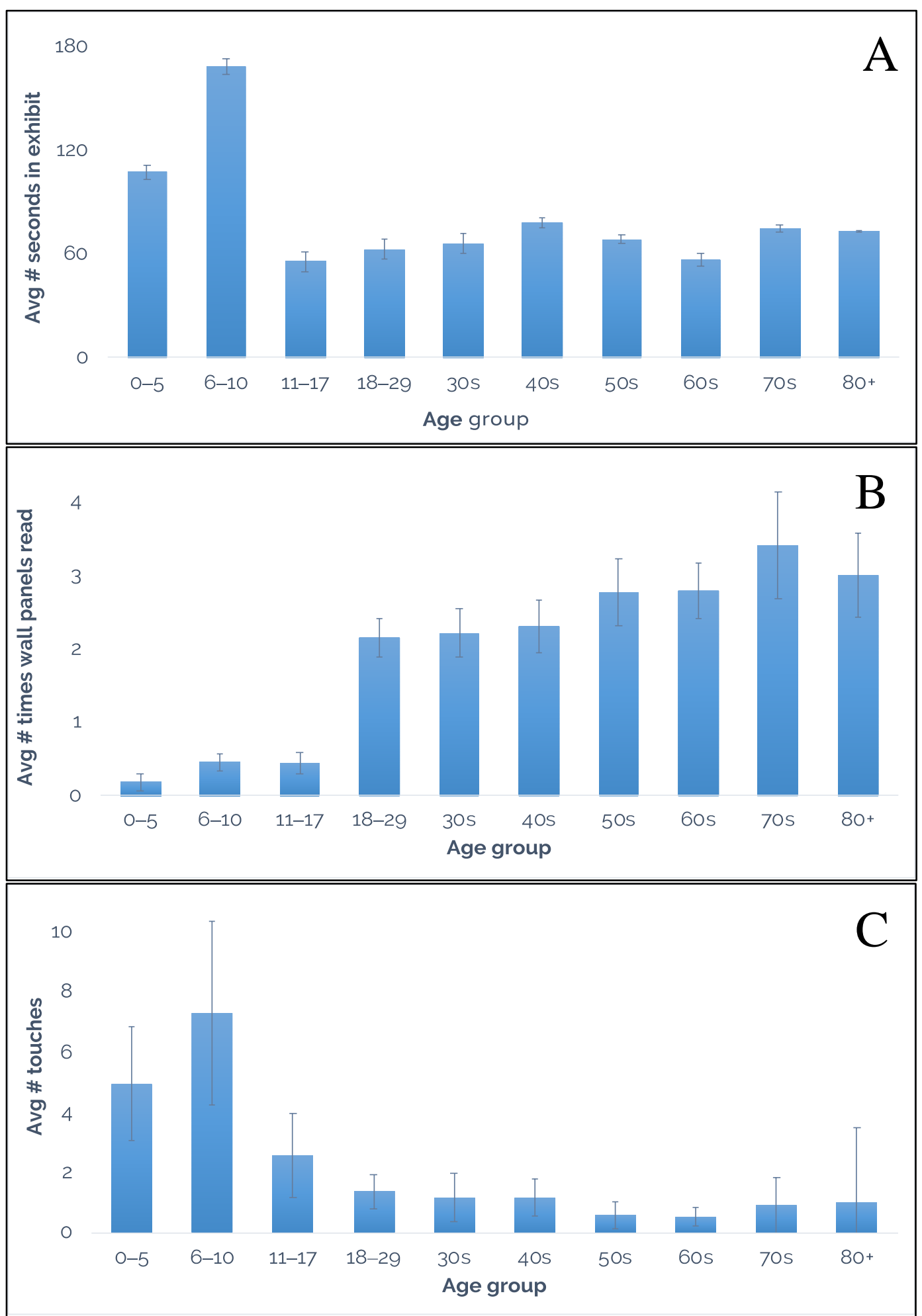

FIGURE 3 (A-C): By age group, average A) number of seconds spent in the ocean plastic exhibit, B) number of times ocean plastic exhibit wall panels were read, and C) number of times ocean plastic exhibit interactive podia were touched. 


\section{Structured Questionnaire}

Structured questionnaires with mixed question types were administered to 93 randomly-selected visitors who engaged with the ocean plastic exhibit (Appendix N: Chapter 4). Our survey group included both females $(n=50)$ and males $(n=43)$, aged $18-$ 29 (youngest), to 70-79 years old (oldest), representing 74 unique zip codes from 12 U.S. states (Arizona, California, Hawaii, Idaho, Kentucky, Nevada, Oklahoma, Oregon, Texas, Utah, Washington, Wisconsin) and two countries (U.S., Italy). The majority of respondents $(64.5 \% ; n=60)$ were repeat OCA visitors. Seventy-one percent of respondents were at OCA with family or friends including children younger than 18 ( $\mathrm{n}=$ 66), while others came with family or friends over the age of 18 ( $n=22)$, by themselves $(n=3)$, or with organized groups $(n=2)$. Most respondents $(87.1 \%$; $=81)$ were first-time visitors to the ocean plastic exhibit.

\section{Communicating key messages}

To determine if visitors understood key messages from the ocean plastic exhibit, we asked, "What do you think the Aquarium was trying to get across to you with this exhibit?" (Question 3, Appendix N: Chapter 4). Responses were thematically categorized, and the top three themes that emerged were: 1) use less plastic, 2) environmental stewardship, and 3) impacts on the environment (Figure 4A). Example responses from each of these categories were, "Start using less plastic, pay more attention. Restoration is important", "Keeping the beaches clean, encouraging kids to take a closer look at plastics", and "The impact of plastic on the environment and sea life". 
To determine what specific information presented in the exhibit was new to visitors, we asked, "Before seeing this exhibit, I never realized that..." (Question 5, Appendix N: Chapter 4). The top three response themes that emerged were: 1) general plastic pollution, 2) awareness, and 3) microplastics (Figure 4B). Examples of responses from each of these categories include: "How big the plastic problem is. Eight million tons dumped every year!", "How many things have plastic in them", and "I have been hearing a lot about microfibers but when I see them, I see why what comes off of my clothes ...impacts on the environment". To determine what information presented was familiar to visitors, we asked, "Seeing this exhibit reminded me that..." (Question 6, Appendix N: Chapter 4). The top three themes that arose were: 1) awareness, 2) reducing or replacing plastics, and 3) environmental stewardship (Figure 4C). Examples of responses from each of these categories were: "We should be mindful of what we throw away and use every day", "I can do better on not using single-use plastics", and "Choices we make have longlasting influence on the environment". 


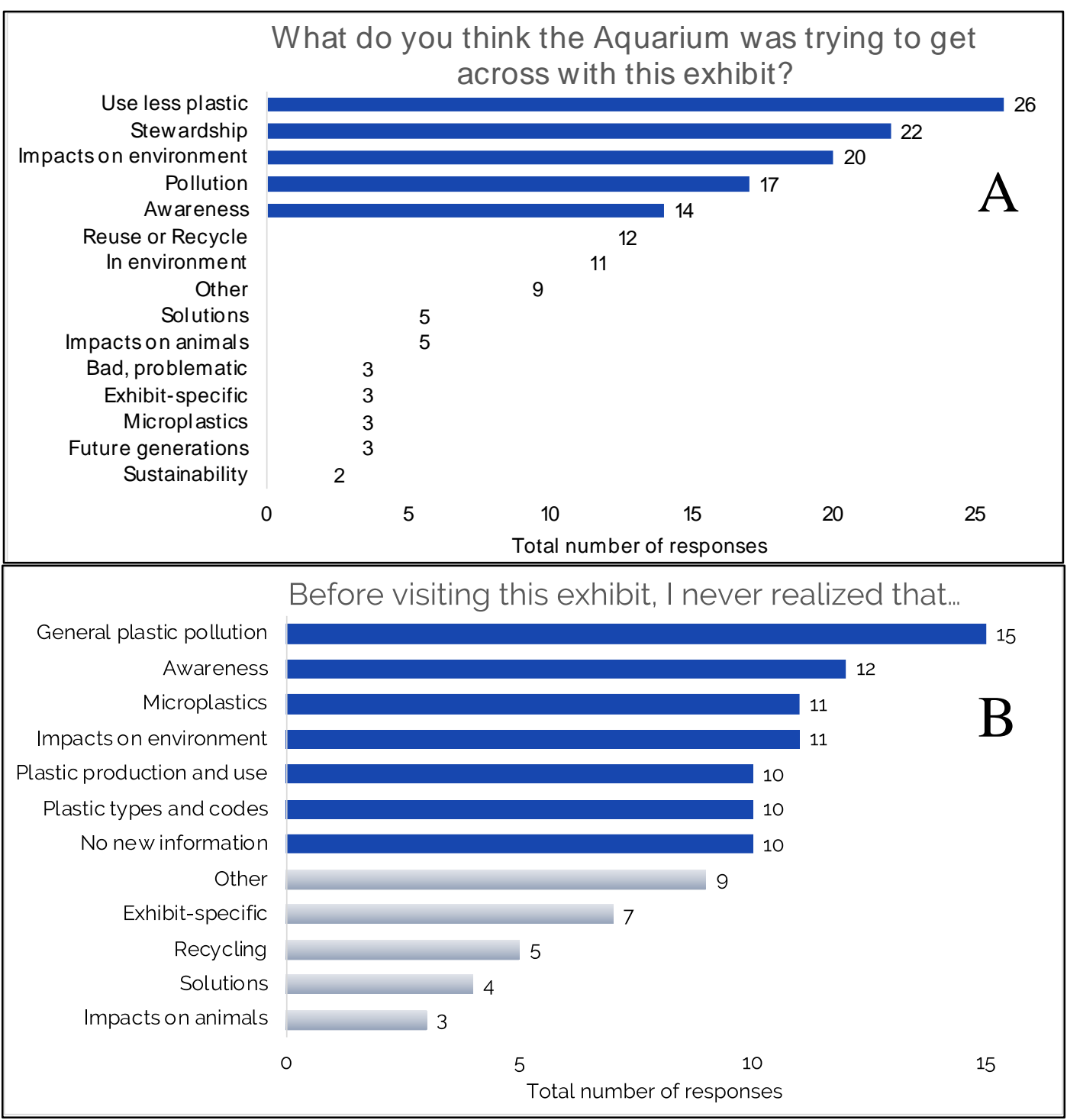




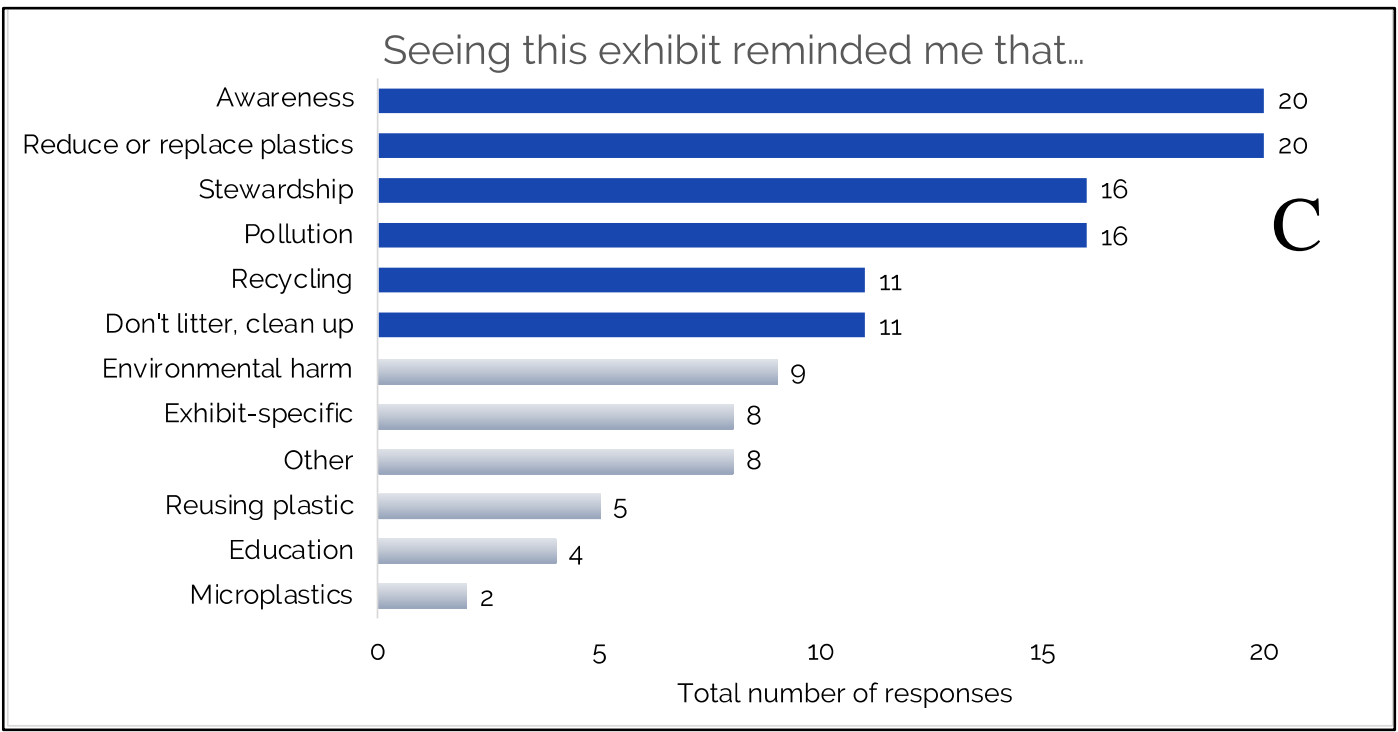

FIGURE 4 (A-C): Thematically coded open-ended responses by 93 Oregon Coast Aquarium visitors to the questions- A) "What do you think the Aquarium was trying to get across to you with this exhibit?"; B) "Before seeing this exhibit, I never realized that..."; and C) "Seeing this exhibit reminded me that...". Top five responses by frequency are represented in blue, remaining responses are represented in gray. Not all respondents provided answers for both questions. Non-responses were excluded from the figure.

We asked respondents to provide two positive words that came to mind when they heard the word 'plastic', followed by two negative words (Questions 13 and 14, Appendix N: Chapter 4). The top three themes for positive words were: 1) convenience and usefulness, 2) durability, and 3) cheap (Appendix R: Chapter 4), and the top themes for negative words were: 1) pollution and litter, 2) long-lasting, and 3) harm to environment or animals (Appendix R: Chapter 4).

Desire to help address the plastic pollution problem

Respondents $(\mathrm{n}=91)$ self-reported their desire to help address the ocean plastic problem before their aquarium visit and after seeing the exhibit (Questions 11A and 11B, Appendix N: Chapter 4). Rankings of desire to help were from $0-4(0=$ low, $4=$ high $)$. Desire rankings were analyzed by gender, age, coastal status, and locality (Table 2). 
Coastal status and locality were generated from zip codes provided. Coastal status was split by states with and without marine coastlines; locality was split between Oregonians and non-Oregonians. Overall, desire to help address the ocean plastic problem increased an average of 0.5 points from 3.2 to 3.7 after seeing the exhibit (Table 2). The largest change in desire was by 18-29 year olds (avg= 2.5 before, 3.5 after; Table 2 ).

TABLE 2. Mean responses for 91 Oregon Coast Aquarium visitors who self-reported their desire to help address the ocean plastic problem before and after seeing the ocean plastic exhibit. Rankings of desire to help were from $0-4(0=$ low, $4=$ high $) .87$ respondents provided zip codes. U.S. states with marine coastlines were CA, HI, OR, TX, and WA; U.S. states with no marine coastlines were AZ, ID, KY, NV, OK, UT and WI. The single respondent with a non-U.S. address (Italy) was excluded from the locality and coastal categories.

\begin{tabular}{|c|c|c|c|c|c|}
\hline & Respondent group & $\begin{array}{l}\text { Number of } \\
\text { respondents }\end{array}$ & $\begin{array}{c}\text { Before seeing } \\
\text { exhibit } \\
\text { Average (SE) }\end{array}$ & $\begin{array}{l}\text { After seeing } \\
\text { Exhibit } \\
\text { Average (SE) }\end{array}$ & $\begin{array}{l}\text { Increase in desire to } \\
\text { help address ocean } \\
\text { plastic problem after } \\
\text { seeing exhibit }\end{array}$ \\
\hline$\ddot{z}$ & All respondents & 91 & $3.2(0.1)$ & $3.7(0.1)$ & 0.5 \\
\hline \multirow{2}{*}{$\frac{\grave{\Phi}}{\frac{1}{0}}$} & Females only & 49 & $3.2(0.1)$ & $3.8(0.1)$ & 0.6 \\
\hline & Males only & 42 & $3.2(0.1)$ & $3.6(0.1)$ & 0.4 \\
\hline \multirow{6}{*}{$\stackrel{Ð}{0}$} & 18-29 only & 12 & $2.5(0.4)$ & $3.5(0.2)$ & 1.0 \\
\hline & 30-39 only & 25 & $3.2(0.2)$ & $3.7(0.1)$ & 0.5 \\
\hline & 40-49 only & 29 & $3.4(0.1)$ & $3.8(0.1)$ & 0.4 \\
\hline & 50-59 only & 11 & $3.5(0.2)$ & $4.0(0.0)$ & 0.5 \\
\hline & $60-69$ only & 9 & $3.6(0.2)$ & $3.8(0.1)$ & 0.2 \\
\hline & 70-79 only & 4 & $3.0(0.7)$ & $3.0(0.7)$ & 0.0 \\
\hline \multirow{2}{*}{$\begin{array}{l}\vec{\pi} \\
\text { 苟 } \\
\text { ס } \\
0\end{array}$} & $\begin{array}{r}\text { States with marine } \\
\text { coastlines }\end{array}$ & 74 & $3.3(0.1)$ & $3.7(0.1)$ & 0.4 \\
\hline & $\begin{array}{r}\text { States with no } \\
\text { marine coastline }\end{array}$ & 11 & $3.3(0.3)$ & $3.7(0.2)$ & 0.4 \\
\hline \multirow{2}{*}{ 写 } & $\begin{array}{r}\text { Oregon zipcodes } \\
\text { only } \\
\end{array}$ & 55 & $3.3(0.1)$ & $3.8(0.1)$ & 0.5 \\
\hline & $\begin{array}{r}\text { Non-Oregon } \\
\text { zipcodes only }\end{array}$ & 30 & $3.1(0.2)$ & $3.6(0.1)$ & 0.5 \\
\hline
\end{tabular}

Note: $\quad \mathrm{SE}=$ Standard Error 
Single-use plastic reduction or plastic stewardship actions and intent to change

Single-use plastic reduction and plastic stewardship actions were self-reported by 91 OCA visitors (Question 4, Appendix N: Chapter 4) who were asked how often they participated in 10 single-use plastic reduction or plastic stewardship actions (1-carry a reusable water bottle, 2-bring your own coffee container, 3-bring your own bag to store or market, 4-choose items not packaged in plastic, 5-specifically ask for no straw, 6-use a reusable straw, 7-clean the beach, 8-carry your own utensils, 9-contact companies or representatives, 10-bring your own containers to restaurants) in their daily lives (Question 4, Appendix N: Chapter 4).

The single-use plastic reduction or plastic stewardship actions with the highest mean value reported were: 1) carry a reusable water bottle, 2) bring your own coffee container, and 3) bring your own bag to the store or market (Table 3). When comparing genders, females $(n=50)$ had higher mean scores than males $(n=41)$ for 7 of 10 actions (Table 3). The youngest age group sampled, 18-29 $(n=12)$, reported the lowest mean scores of all age groups for 7 of 10 actions and were second lowest for the remaining 3 actions (specifically ask for no straw, clean the beach, and carry your own utensils; Table 3). Respondents from states with marine coastlines $(n=76)$ reported higher mean responses to all actions except bringing their own containers to restaurants, in which case respondents from inland states $(\mathrm{n}=11)$ had a higher mean score (Table 3). Mean action scores were not markedly different between Oregonians $(n=56)$ and non-Oregonians $(n=$ 31 ), as Oregonians reported higher mean action scores for 5 actions, tied with non- 
Oregonians for 1 action, and were outranked by non-Oregonians for the remaining 4 actions (Table 3 ).

TABLE 3. Mean responses for 91 questionnaire respondents who self-reported single-use plastic or plastic stewardship actions (prior to seeing exhibit). Actions are sorted left to right from highest to lowest mean response for all respondents. Responses are divided by gender, age, coastal status, and locality. $0=$ Never; $1=$ Rarely (I have done this a couple of times); $2=$ Sometimes (about once or twice a week); $3=$ Frequently (three or more days a week); $4=$ Almost every day. NAs and non-responses were excluded. There were no responses for the $80+$ category. Only 87 respondents provided zip codes. U.S. states with marine coastlines were CA, HI, OR, TX, and WA; U.S. states with no marine coastlines were AZ, ID, KY, NV, OK, UT and WI. The single respondent with a non-U.S. address (Italy) was excluded from the locality and coastal categories.

\begin{tabular}{|c|c|c|c|c|c|c|c|c|c|c|c|c|}
\hline & Respondent group & $\begin{array}{l}\begin{array}{l}\text { Number of } \\
\text { respondents }\end{array} \\
\end{array}$ & \begin{tabular}{|l|} 
Carry a \\
reusable \\
water bottle \\
\end{tabular} & $\begin{array}{l}\text { BYo coffee } \\
\text { container }\end{array}$ & \begin{tabular}{|l|} 
BYO bag to \\
store or \\
market
\end{tabular} & \begin{tabular}{|l|}
$\begin{array}{l}\text { Choose items } \\
\text { not packaged } \\
\text { in plastic }\end{array}$ \\
\end{tabular} & \begin{tabular}{|l|}
$\begin{array}{l}\text { Specifically } \\
\text { ask for no } \\
\text { straw }\end{array}$ \\
\end{tabular} & \begin{tabular}{|l|}
$\begin{array}{l}\text { Use a } \\
\text { reusable } \\
\text { straw }\end{array}$ \\
\end{tabular} & \begin{tabular}{|l|}
$\begin{array}{l}\text { Clean } \\
\text { the } \\
\text { beach }\end{array}$ \\
\end{tabular} & \begin{tabular}{|l|}
$\begin{array}{l}\text { Carry } \\
\text { your own } \\
\text { utensils }\end{array}$ \\
\end{tabular} & \begin{tabular}{|l|}
$\begin{array}{l}\text { Contact } \\
\text { companies or } \\
\text { representatives }\end{array}$ \\
\end{tabular} & \begin{tabular}{|l} 
BYO \\
containers to \\
restaurant
\end{tabular} \\
\hline ₹ & All respondents & 91 & 3.4 & 2.6 & 2.5 & 2.1 & 1.7 & 1.6 & 1.5 & 1.0 & 0.4 & 0.4 \\
\hline \multirow{2}{*}{ 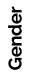 } & Females only & 50 & 3.6 & 2.7 & 2.6 & 2.2 & 1.8 & 1.6 & 1.6 & 0.9 & 0.4 & 0.3 \\
\hline & Males only & 41 & 3.3 & 2.6 & 2.4 & 1.9 & 1.7 & 1.5 & 1.4 & 1.0 & 0.5 & 0.4 \\
\hline \multirow{6}{*}{$\stackrel{9}{8}$} & 18-29 only & 12 & 3.3 & 1.7 & 1.1 & 1.5 & 1.2 & 0.7 & 0.8 & 0.7 & 0.0 & 0.0 \\
\hline & 30-39 only & 26 & 3.4 & 2.6 & 2.4 & 2.3 & 1.9 & 2.0 & 1.7 & 1.0 & 0.2 & 0.3 \\
\hline & 40-49 only & 30 & 3.7 & 2.8 & 3.0 & 2.1 & 1.9 & 1.6 & 1.7 & 1.2 & 0.5 & 0.7 \\
\hline & 50-59 only & 11 & 3.7 & 3.2 & 2.5 & 2.6 & 1.9 & 1.9 & 1.9 & 0.9 & 1.0 & 0.2 \\
\hline & $60-69$ only & 9 & 2.7 & 2.5 & 2.9 & 1.6 & 1.4 & 1.0 & 0.5 & 1.1 & 0.4 & 0.1 \\
\hline & $70-79$ only & 3 & 3.3 & 4.0 & 4.0 & 1.7 & 1.0 & 1.0 & 2.3 & 0.0 & 0.3 & 0.0 \\
\hline \multirow{2}{*}{ 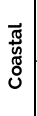 } & $\begin{array}{r}\text { States with marine } \\
\text { coastlines }\end{array}$ & 76 & 3.5 & 2.7 & 2.6 & 2.1 & 1.7 & 1.5 & 1.6 & 1.1 & 0.4 & 0.3 \\
\hline & $\begin{array}{r}\text { States with no } \\
\text { marine coastline }\end{array}$ & 11 & 3.3 & 2.4 & 2.0 & 1.8 & 1.6 & 1.4 & 1.0 & 0.5 & 0.3 & 0.5 \\
\hline \multirow{2}{*}{ 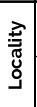 } & $\begin{array}{r}\text { Oregon zipcodes } \\
\text { only }\end{array}$ & 56 & 3.5 & 2.8 & 2.5 & 2.1 & 1.6 & 1.6 & 1.4 & 1.2 & 0.3 & 0.2 \\
\hline & $\begin{array}{r}\text { Non-Oregon } \\
\text { zipcodes only }\end{array}$ & 31 & 3.4 & 2.4 & 2.5 & 2.0 & 1.9 & 1.5 & 1.8 & 0.7 & 0.6 & 0.6 \\
\hline
\end{tabular}

Note: $\mathrm{BYO}=$ Bring your own.

Actions with the highest percentage of respondents reporting intended change

were for using a reusable straw (37.4\%), cleaning the beach (37.4\%), bring-your-own (BYO) bag to the store or market (33/0\%), and carrying your own utensils $(30.8 \%$; Table 4). Percent of respondents reporting intended change for other actions ranged from $11.0 \%-27.5 \%$ (Table 4). All age groups (18-29, 30-69, 70+) reported at least some intended changes for single-use plastic reduction and plastic stewardship actions. The 1829 and 30-69 groups reported intended change $\geq 14.9 \%$ for all 10 actions, whereas the 70 79 year old group reported intended change for only 7 of 10 actions, with no intended 
changes to carrying a reusable water bottle, carrying own utensils or BYO containers to restaurants (Table 4). When respondents were divided into those residing in states with $(n=76)$ and without $(n=11)$ marine coastlines, those residing in states with no marine coastline reported the highest percent of intended change for BYO coffee containers (54.5\%) and specifically ask for no straw (54.5\%). In most cases, the percentage of respondents reporting probable change was greater than or equal to the percentage reporting definite change, except there was a high proportion of respondent groups for which definite change was greater than or equal to the percentage reporting probable change for the carry a reusable water bottle action (Table 4). Oregon residents were more likely to change some plastic use actions than non-residents, and younger (18-50s) respondents were more likely to change their actions than older $(60 s-80+)$ respondents (Table 4). 
TABLE 4. Percentage of Oregon Coast Aquarium visitors that self-reported intended single-use plastic or plastic-related environmental stewardship action changes after seeing the exhibit. Per respondent group, intended change is reported as: total percentage (number of individuals in the group reporting either probable -"probably will start doing or increase", or definite - "definitely will start doing or increase" behavior change); percentage reporting probable change, and percentage reporting definite change. Groups and actions reporting $\geq 40 \%$ total change are colored green. Groups and actions where $\%$ reporting definite change $>\%$ reporting probable change are colored blue. Age was divided into three groups based on similarity of responses. Only 87 respondents provided zip codes. U.S. states with marine coastlines were CA, HI, OR, TX, and WA; U.S. states with no marine coastlines were AZ, ID, KY, NV, OK, UT and WI. The single respondent with a non-U.S. address (Italy) was excluded from the locality and coastal categories.

\begin{tabular}{|c|c|c|c|c|c|c|c|c|c|c|c|c|}
\hline & $\begin{array}{l}\text { Respondent } \\
\text { group }(n=)\end{array}$ & $\begin{array}{l}\text { Percentage of } \\
\text { change }\end{array}$ & $\begin{array}{c}\text { Carry a } \\
\text { reusable } \\
\text { water bottle }\end{array}$ & $\begin{array}{c}\text { BYO } \\
\text { coffee } \\
\text { container }\end{array}$ & $\begin{array}{c}\text { BYo bag } \\
\text { to store or } \\
\text { market }\end{array}$ & $\begin{array}{c}\text { Choose items } \\
\text { not packaged in } \\
\text { plastic }\end{array}$ & $\begin{array}{l}\text { Specifically } \\
\text { ask for no } \\
\text { straw }\end{array}$ & $\begin{array}{l}\text { Usea } \\
\text { reusable } \\
\text { straw }\end{array}$ & $\begin{array}{l}\text { Clean } \\
\text { the } \\
\text { beach }\end{array}$ & $\begin{array}{c}\text { Carry your } \\
\text { own } \\
\text { utensils }\end{array}$ & $\begin{array}{c}\text { Contact } \\
\text { companies or } \\
\text { representatives }\end{array}$ & $\begin{array}{c}\text { BYO } \\
\text { containers to } \\
\text { restaurant }\end{array}$ \\
\hline \multirow{3}{*}{ ₹ } & \multirow{3}{*}{ All $(n=91)$} & \begin{tabular}{|c|}
$\begin{array}{c}\% \text { reporting change } \\
\text { (total) }\end{array}$ \\
\end{tabular} & $11.0 \%$ & $27.5 \%$ & $33.0 \%$ & $15.4 \%$ & $28.6 \%$ & $37.4 \%$ & $37.4 \%$ & $30.8 \%$ & $24.2 \%$ & $25.3 \%$ \\
\hline & & \begin{tabular}{c|}
$\%$ reporting \\
probable change
\end{tabular} & $4.4 \%$ & $15.4 \%$ & $24.2 \%$ & $9.9 \%$ & $18.7 \%$ & $20.9 \%$ & $26.4 \%$ & $20.9 \%$ & $18.7 \%$ & $22.0 \%$ \\
\hline & & $\begin{array}{c}\% \text { reporting definite } \\
\text { change }\end{array}$ & $6.6 \%$ & $12.1 \%$ & $8.8 \%$ & $5.5 \%$ & $9.9 \%$ & $16.5 \%$ & $11.0 \%$ & $9.9 \%$ & $5.5 \%$ & $3.3 \%$ \\
\hline \multirow{6}{*}{ 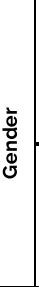 } & \multirow{3}{*}{$\begin{array}{c}\text { Females only } \\
(n=50)\end{array}$} & \begin{tabular}{|c|}
$\begin{array}{c}\% \text { reporting change } \\
\text { (total) }\end{array}$ \\
\end{tabular} & $10.0 \%$ & $32.0 \%$ & $40.0 \%$ & $12.0 \%$ & $22.0 \%$ & $36.0 \%$ & $42.0 \%$ & $32.0 \%$ & $26.0 \%$ & $30.0 \%$ \\
\hline & & \begin{tabular}{|c|}
$\%$ reporting \\
probable change \\
\end{tabular} & $4.0 \%$ & $16.0 \%$ & $26.0 \%$ & $6.0 \%$ & $14.0 \%$ & $22.0 \%$ & $32.0 \%$ & $20.0 \%$ & $20.0 \%$ & $24.0 \%$ \\
\hline & & $\begin{array}{c}\% \text { reporting definite } \\
\text { change }\end{array}$ & $6.0 \%$ & $16.0 \%$ & $14.0 \%$ & $6.0 \%$ & $8.0 \%$ & $14.0 \%$ & $10.0 \%$ & $12.0 \%$ & $6.0 \%$ & $6.0 \%$ \\
\hline & \multirow{3}{*}{$\begin{array}{l}\text { Males only } \\
\quad(n=41)\end{array}$} & $\begin{array}{c}\% \text { reporting change } \\
\text { (total) }\end{array}$ & $12.2 \%$ & $22.0 \%$ & $24.4 \%$ & $19.5 \%$ & $36.6 \%$ & $39.0 \%$ & $31.7 \%$ & $29.3 \%$ & $22.0 \%$ & $19.5 \%$ \\
\hline & & $\begin{array}{c}\text { \% reporting } \\
\text { probable change }\end{array}$ & $4.9 \%$ & $14.6 \%$ & $22.0 \%$ & $14.6 \%$ & $24.4 \%$ & $19.5 \%$ & $19.5 \%$ & $22.0 \%$ & $17.1 \%$ & $19.5 \%$ \\
\hline & & $\begin{array}{c}\% \text { reporting definite } \\
\text { change }\end{array}$ & $7.3 \%$ & $7.3 \%$ & $2.4 \%$ & $4.9 \%$ & $12.2 \%$ & $19.5 \%$ & $12.2 \%$ & $7.3 \%$ & $4.9 \%$ & $0.0 \%$ \\
\hline \multirow{9}{*}{$\stackrel{2}{8}$} & \multirow{3}{*}{$\begin{array}{l}\text { 18-29 only } \\
(n=12)\end{array}$} & \begin{tabular}{|c|}
$\begin{array}{c}\text { \% reporting change } \\
\text { (total) }\end{array}$ \\
\end{tabular} & $25.0 \%$ & $16.7 \%$ & $33.3 \%$ & $16.7 \%$ & $33.3 \%$ & $41.7 \%$ & $25.0 \%$ & $41.7 \%$ & $25.0 \%$ & $25.0 \%$ \\
\hline & & $\begin{array}{c}\% \text { reporting } \\
\text { probable change }\end{array}$ & $0.0 \%$ & $8.3 \%$ & $16.7 \%$ & $0.0 \%$ & $8.3 \%$ & $33.3 \%$ & $16.7 \%$ & $33.3 \%$ & $25.0 \%$ & $16.7 \%$ \\
\hline & & $\begin{array}{c}\% \text { reporting definite } \\
\text { change }\end{array}$ & $25.0 \%$ & $8.3 \%$ & $16.7 \%$ & $16.7 \%$ & $25.0 \%$ & $8.3 \%$ & $8.3 \%$ & $8.3 \%$ & $0.0 \%$ & $8.3 \%$ \\
\hline & \multirow{3}{*}{$\begin{array}{c}30-69 \text { only } \\
(n=74)\end{array}$} & $\begin{array}{c}\% \begin{array}{c}\% \text { reporting change } \\
\text { (total) }\end{array} \\
\end{array}$ & $9.5 \%$ & $14.9 \%$ & $25.7 \%$ & $31.1 \%$ & $36.5 \%$ & $29.7 \%$ & $23.0 \%$ & $31.1 \%$ & $25.7 \%$ & $41.9 \%$ \\
\hline & & $\begin{array}{c}\% \text { reporting } \\
\text { probable change }\end{array}$ & $5.4 \%$ & $9.5 \%$ & $14.9 \%$ & $21.6 \%$ & $21.6 \%$ & $20.3 \%$ & $17.6 \%$ & $20.3 \%$ & $21.6 \%$ & $29.7 \%$ \\
\hline & & $\begin{array}{c}\% \text { reporting definite } \\
\text { change }\end{array}$ & $4.1 \%$ & $5.4 \%$ & $10.8 \%$ & $9.5 \%$ & $14.9 \%$ & $9.5 \%$ & $5.4 \%$ & $10.8 \%$ & $4.1 \%$ & $12.2 \%$ \\
\hline & \multirow{3}{*}{$\begin{array}{c}70-79 \text { only } \\
(n=4)\end{array}$} & \begin{tabular}{|c|}
$\begin{array}{c}\% \text { reporting change } \\
\text { (total) }\end{array}$ \\
\end{tabular} & $0.0 \%$ & $25.0 \%$ & $50.0 \%$ & $25.0 \%$ & $50.0 \%$ & $50.0 \%$ & $50.0 \%$ & $0.0 \%$ & $25.0 \%$ & $0.0 \%$ \\
\hline & & $\begin{array}{c}\% \text { reporting } \\
\text { probable change }\end{array}$ & $0.0 \%$ & $25.0 \%$ & $25.0 \%$ & $25.0 \%$ & $25.0 \%$ & $50.0 \%$ & $50.0 \%$ & $0.0 \%$ & $25.0 \%$ & $0.0 \%$ \\
\hline & & $\begin{array}{c}\% \text { reporting definite } \\
\text { change }\end{array}$ & $0.0 \%$ & $0.0 \%$ & $25.0 \%$ & $0.0 \%$ & $25.0 \%$ & $0.0 \%$ & $0.0 \%$ & $0.0 \%$ & $0.0 \%$ & $0.0 \%$ \\
\hline \multirow{6}{*}{$\begin{array}{l}\vec{\pi} \\
\text { जू } \\
0 \\
0 \\
0\end{array}$} & \multirow{3}{*}{$\begin{array}{l}\text { States with } \\
\text { marine } \\
\text { coastlines } \\
(n=76)\end{array}$} & \begin{tabular}{|c|}
$\begin{array}{c}\% \text { reporting change } \\
\text { (total) }\end{array}$ \\
\end{tabular} & $10.5 \%$ & $23.7 \%$ & $34.2 \%$ & $17.1 \%$ & $23.7 \%$ & $36.8 \%$ & $39.5 \%$ & $31.6 \%$ & $22.4 \%$ & $26.3 \%$ \\
\hline & & \begin{tabular}{c|}
$\%$ reporting \\
probable change \\
\end{tabular} & $2.6 \%$ & $13.2 \%$ & $26.3 \%$ & $11.8 \%$ & $17.1 \%$ & $21.1 \%$ & $28.9 \%$ & $23.7 \%$ & $17.1 \%$ & $25.0 \%$ \\
\hline & & $\begin{array}{c}\% \text { reporting definite } \\
\text { change }\end{array}$ & $7.9 \%$ & $10.5 \%$ & $7.9 \%$ & $5.3 \%$ & $6.6 \%$ & $15.8 \%$ & $10.5 \%$ & $7.9 \%$ & $5.3 \%$ & $1.3 \%$ \\
\hline & \multirow{3}{*}{$\begin{array}{c}\text { States with no } \\
\text { marine } \\
\text { coastline } \\
(n=11)\end{array}$} & \begin{tabular}{|c|}
$\begin{array}{c}\% \text { reporting change } \\
\text { (total) }\end{array}$ \\
\end{tabular} & $9.1 \%$ & $54.5 \%$ & $18.2 \%$ & $9.1 \%$ & $54.5 \%$ & $45.5 \%$ & $27.3 \%$ & $18.2 \%$ & $45.5 \%$ & $18.2 \%$ \\
\hline & & \begin{tabular}{c|}
$\%$ reporting \\
probable change \\
\end{tabular} & $9.1 \%$ & $36.4 \%$ & $18.2 \%$ & $0.0 \%$ & $27.3 \%$ & $27.3 \%$ & $18.2 \%$ & $0.0 \%$ & $36.4 \%$ & $9.1 \%$ \\
\hline & & \begin{tabular}{|c|}
$\begin{array}{c}\% \text { reporting definite } \\
\text { change }\end{array}$ \\
\end{tabular} & $0.0 \%$ & $18.2 \%$ & $0.0 \%$ & $9.1 \%$ & $27.3 \%$ & $18.2 \%$ & $9.1 \%$ & $18.2 \%$ & $9.1 \%$ & $9.1 \%$ \\
\hline \multirow{6}{*}{ 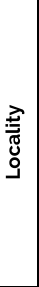 } & \multirow{3}{*}{$\begin{array}{c}\text { Oregon } \\
\text { zipcodes only } \\
(n=56)\end{array}$} & \begin{tabular}{|c|}
$\begin{array}{c}\% \text { reporting change } \\
\text { (total) }\end{array}$ \\
\end{tabular} & $10.7 \%$ & $23.2 \%$ & $33.9 \%$ & $17.9 \%$ & $21.4 \%$ & $37.5 \%$ & $41.1 \%$ & $26.8 \%$ & $23.2 \%$ & $25.0 \%$ \\
\hline & & \begin{tabular}{c|}
$\%$ reporting \\
probable change \\
\end{tabular} & $1.8 \%$ & $12.5 \%$ & $23.2 \%$ & $10.7 \%$ & $16.1 \%$ & $23.2 \%$ & $28.6 \%$ & $21.4 \%$ & $17.9 \%$ & $25.0 \%$ \\
\hline & & \begin{tabular}{|c|}
$\begin{array}{c}\% \text { reporting definite } \\
\text { change }\end{array}$ \\
\end{tabular} & $8.9 \%$ & $10.7 \%$ & $10.7 \%$ & $7.1 \%$ & $5.4 \%$ & $14.3 \%$ & $12.5 \%$ & $5.4 \%$ & $5.4 \%$ & $0.0 \%$ \\
\hline & \multirow{3}{*}{$\begin{array}{c}\text { Non-Oregon } \\
\text { zipcodes only } \\
\quad(n=31)\end{array}$} & \begin{tabular}{|c|}
$\begin{array}{c}\% \text { reporting change } \\
\text { (total) }\end{array}$ \\
\end{tabular} & $9.7 \%$ & $35.5 \%$ & $29.0 \%$ & $12.9 \%$ & $38.7 \%$ & $38.7 \%$ & $32.3 \%$ & $35.5 \%$ & $29.0 \%$ & $25.8 \%$ \\
\hline & & $\begin{array}{c}\% \text { reporting } \\
\text { probable change } \\
\end{array}$ & $6.5 \%$ & $22.6 \%$ & $29.0 \%$ & $9.7 \%$ & $22.6 \%$ & $19.4 \%$ & $25.8 \%$ & $19.4 \%$ & $22.6 \%$ & $19.4 \%$ \\
\hline & & $\begin{array}{c}\% \text { reporting definite } \\
\text { change }\end{array}$ & $3.2 \%$ & $12.9 \%$ & $0.0 \%$ & $3.2 \%$ & $16.1 \%$ & $19.4 \%$ & $6.5 \%$ & $16.1 \%$ & $6.5 \%$ & $6.5 \%$ \\
\hline
\end{tabular}

Note: $\mathrm{BYO}=$ Bring your own. 


\section{Impressions \& Learning}

Overall, the ocean plastic exhibit left very positive impressions on respondents. When asked, "How would you rate your overall impression of this exhibit?" on a scale of $0-4$, ( 0 being low and 4 being high $)$, the average score was $3.60(n=93$; range $=2-4)$, with 96.7\% $(n=88)$ rating the exhibit either a 3 or 4 (Question 15, Appendix N: Chapter 4), and $62.6 \%(n=57)$ giving the highest possible mark of a 4 . When asked, "On a scale of 'Strongly disagree' to 'Strongly agree': I learned from interacting with this exhibit' (Question 8, Appendix N: Chapter 4), 50\% of respondents $(n=46)$ agreed, $43.5 \%(n=$ 40) strongly agreed, 5.4\% $(n=5)$ were neutral, and $1.1 \%(n=1)$ strongly disagreed. Roughly $70 \%(n=65)$ of respondents reported coming to the Aquarium with a child or children (age range of respondent-associated children= 10 months -17 years); of those 65 individuals who were asked: "Please answer this statement on a scale of 'Strongly disagree' to 'Strongly agree': My child learned from interacting with this exhibit" (Question 9B, Appendix N: Chapter 4), 46.2\% ( $\mathrm{n}=30)$ agreed, 35.4\% $(\mathrm{n}=23)$ strongly agreed, $16.9 \%(n=11)$ were neutral, $1.5 \%(n=1)$ disagreed, and $0 \%(n=0)$ strongly disagreed.

\section{$\underline{\text { Most liked exhibit elements and suggested areas for improvement }}$}

When asked "What did you like best about the exhibit", most respondents $(n=30)$ liked the interactive, hands-on nature of the exhibit best (Figure 5A; Question 9AAppendix N: Chapter 4). The information presented, design of the exhibit, learning opportunities afforded, and the Zoom in on microplastics stand element in particular, were also well-liked (Figure 5A). Children of the respondents liked the Zoom in on 
microplastics stand best (43.7\%; $\mathrm{n}=31)$, followed by the Can You Help Clean the Beach?

stand $(29.6 \% ; \mathrm{n}=21$; Figure $5 B)$.

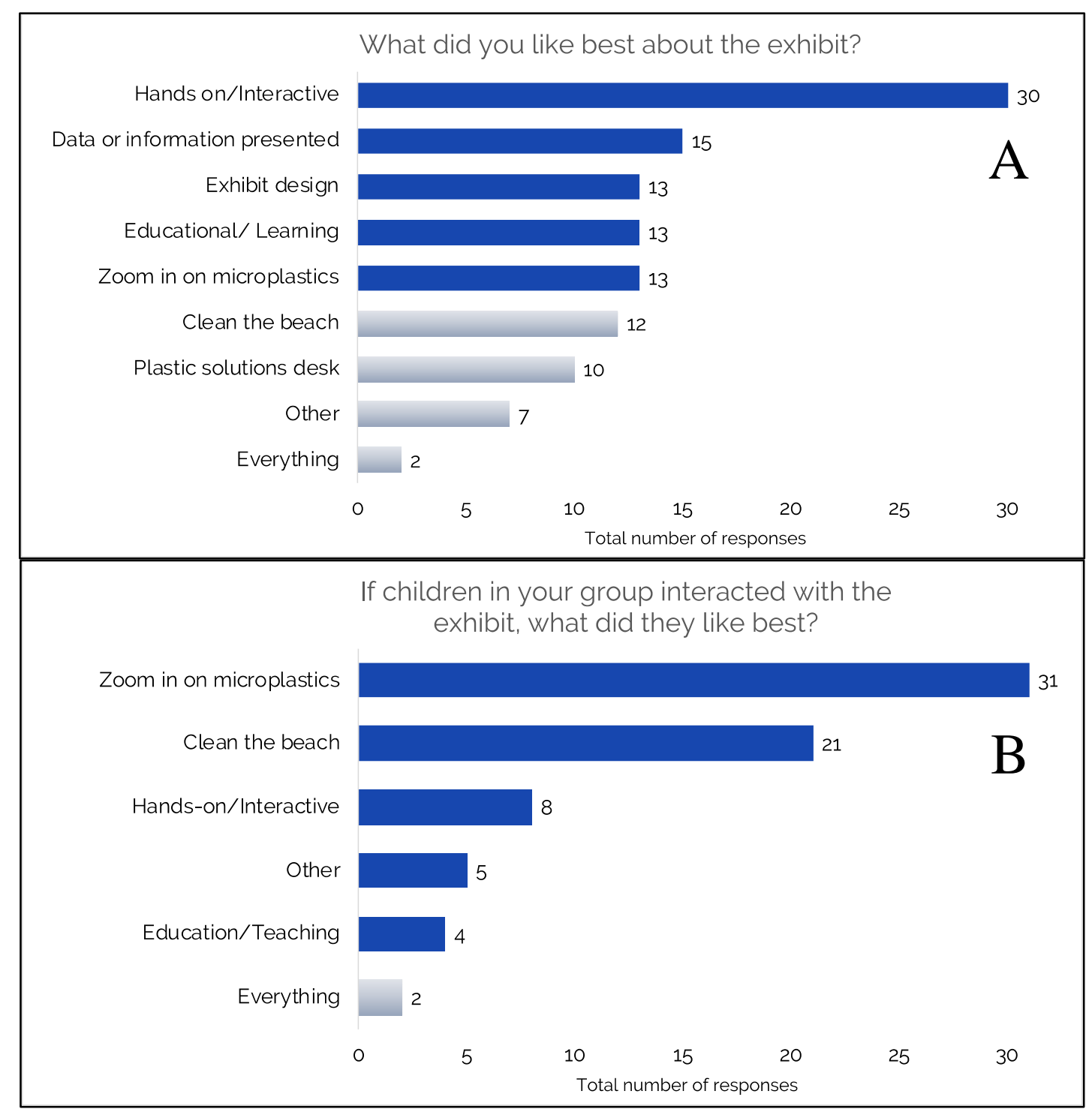




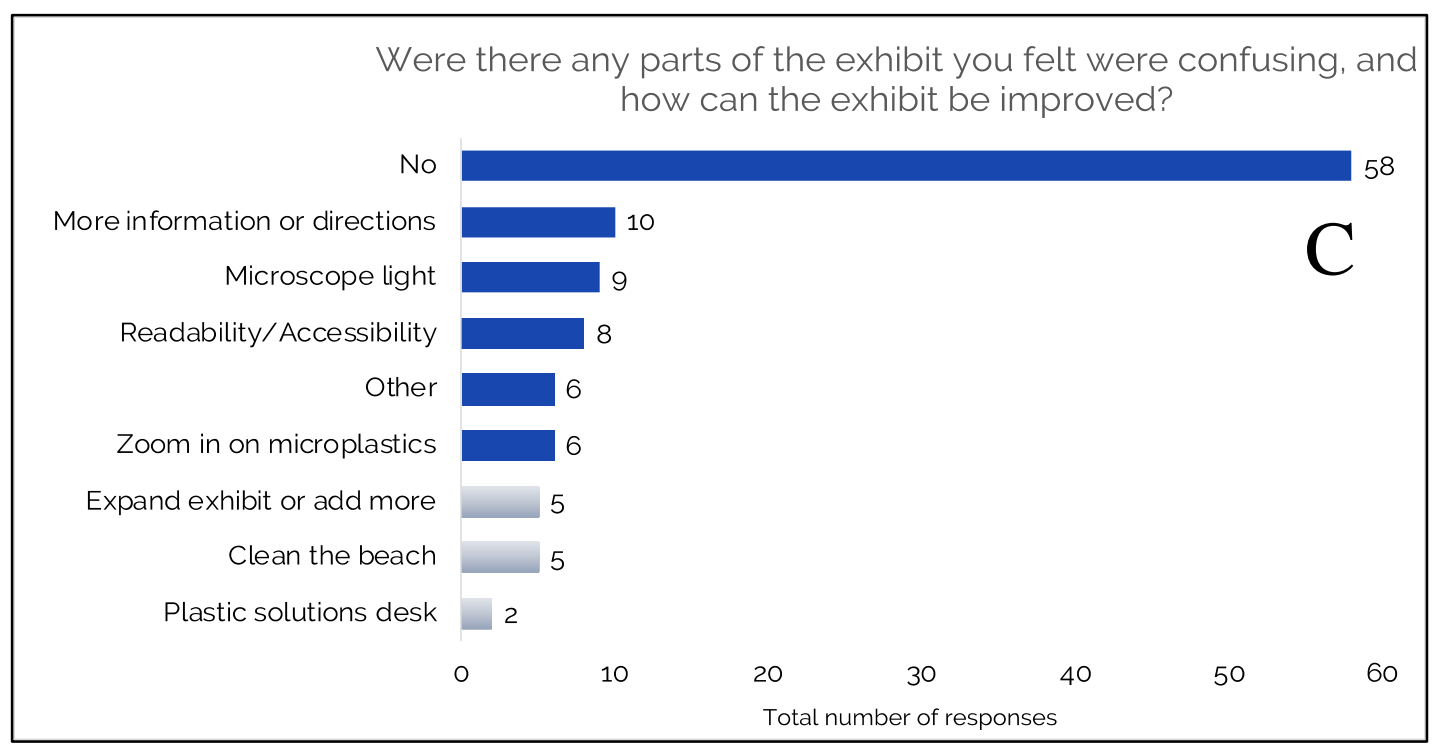

FIGURE 5. (A-C): Thematically categorized open-ended responses by 93 Oregon Coast Aquarium visitors for the questions: A) "What did you like best about the exhibit"; B) "If children in your group interacted with the exhibit, what did they like best?"; and C) "Were there any parts of the exhibit you felt were confusing and how could the exhibit be improved?". Top five responses by frequency are represented with blue bars, remaining responses are represented with gray bars. Non-responses due to no children in the group were not included in Figure 5B. Note: the microscope light did not work during the August sampling period.

When asked, "Were there any parts of the exhibit you felt were confusing, and how could the exhibit be improved?", most respondents $(53.2 \% ; \mathrm{n}=58)$ said 'no' (Figure 5C; Question 10, Appendix N: Chapter 4). The most common areas identified for potential exhibit improvement were adding more information or directions to the interactive elements and adjusting/fixing the microscope light (Figure 5C). The microscope light malfunctioned during the August data collection period, but was repaired for the November data collection period. 


\subsection{Discussion and Conclusions:}

Using education to promote shifts in individual behaviors or actions that reduce single-use plastic is one tool among many that must be employed to meaningfully reduce ocean plastic pollution going forward. Emphases must also be placed further upstream at the production level, well before plastic products reach market shelves or consumer hands, so that unnecessary and dangerous single-use products are no longer produced en masse and are prevented from reaching coasts and oceans. We created an exhibit at the Oregon Coast Aquarium to illustrate the problem of ocean plastic, focusing on conservation messaging that offered visitors an opportunity to contribute to a suite of solutions. Our findings illuminate strategies for future ocean plastic exhibits to effectively reach broad audiences, including specific single-use plastic reduction and plastic stewardship actions that could be effective targets for education and outreach.

As expected, Children (0-17 years) rarely looked at the informational panels but gravitated toward the interactive exhibit elements; this could be partially due to the fact that young children that cannot read may naturally be attracted to interactive features rather than visuals (Ross and Gillespie 2008). There were no significant differences in total time spent in the exhibit when comparing peak (August) and off-season (November) timeframes, or day of the week; this was a surprising result, as dense crowds around exhibits may influence time spent in an exhibit by either discouraging or encouraging interest (Yalowitz and Bronnenkant 2009). Crowds within the exhibit were visibly larger in August than November, and on weekends than weekdays. 
While respondents' intentions to change single-use plastic stewardship actions were evident, for a number of respondent groups there was greater than a $10 \%$ difference between probable and definite changes to their actions (Table 4). These differences should be considered for targeted outreach to respective respondent groups to further encourage behavioral change. Up to $37.4 \%$ of respondents were receptive to changing some actions- namely using reusable straws, cleaning the beach, carrying your own utensils and BYO bag to the store or market. If people report that they want to try new behaviors, promoting these behaviors more broadly may be more successful since people are receptive to making self-reported changes. Providing simple, clear-cut guidance on ways to effectively implement those changes in daily life may also facilitate adoption of those actions. Conversely, respondents were unlikely to propose changing how frequently they carry a reusable water bottle, specifically choose items not packaged in plastic, contact companies or representatives, and BYO containers to a restaurant. It is likely the small intent to change carrying a reusable water bottle was because that behavior had already been widely adopted by respondents prior to seeing the exhibit (Appendix S: Chapter 4); however, for the other three, providing carefully-crafted and widely available information on the ways these actions reduce ocean plastic, and distributing guidance regarding simple techniques for adopting these actions could help move the dial on household single-use plastic reduction.

To date, environmental behaviors have largely been quantified through selfreporting due to low cost and ease of data collection (Pahl and Wyles 2017). Selfreported behaviors can be used to gauge behavior in real-life scenarios, though they are 
not perfect reflections of reality (Bamberg and Möser 2007; Kormos and Gifford 2014;

Pahl and Wyles 2017). As with other behavioral studies, including those where individuals self-report intended behavioral changes, our study has inherent limitations. The extent to which aquarium visitors learn from exhibits and subsequently change behaviors can depend on outside factors including their motivations for visiting the aquarium, pre-existing perceptions, knowledge, interests, and personal experiences (Moussouri 1997; Falk and Adelman 2003; Storksdieck 2006). We did not ground truth whether intended single-use plastic reduction or plastic stewardship actions resulted in actual behavioral changes after interacting with the ocean plastic exhibit.

Of all age groups in our study, 18-29 year olds had the highest change in desire to help address the ocean plastic problem before and after seeing the exhibit (Table 2), but the lowest mean scores for most of the 10 single-use plastic and stewardship actions examined (Table 3). The former could be because 18-29 year olds reported the lowest score of any age group for desire to help address the ocean plastic problem prior to seeing the exhibit and thus had the most room for growth of any age group post-exhibit. Though this group reported a strong desire to decrease contributions to ocean plastic, they are evidently failing to take actions to make that happen. This suggests a mismatch between their awareness of, or sense of personal responsibility for, the ocean plastic problem and concrete plastic-reduction or stewardship actions-a trend that has been previously identified for this generation (Heidbreder et al. 2019). This may be because some groups don't see the plastic problem as an individual problem and instead view it as a societal problem. This can result in a failure to take action (Nalven 2019). Further cultivating a 
civic responsibility mindset for this age group with specific educational or outreach goals and remedial actions should be explored to close the awareness-to-action gap, leading to long-lasting behavioral changes and positive environmental outcomes.

Future work monitoring durable changes to single-use plastic or plastic-related environmental stewardship actions after educational experiences or interventions is needed to ground truth behavioral outcomes. Long-term behavioral changes are of immense importance given the longevity of plastics in the environment and need for sustained, permanent changes to individual plastic consumption as a means to improve environmental health. Reinforcing plastic reduction messaging over time for all age levels can aid in driving behavioral shifts that reduce single-use plastic dependency, ultimately leading to long-lasting positive change. 


\subsection{Acknowledgements:}

Funding for this project was provided by Oregon Sea Grant (award \#NA14OAR4170064 to EFG), and the 2019 Hatfield Marine Science Center Wick Award to BB. Special thanks to Nini Bui for donating her time to design and create the zine cartoon booklet and to Hanna Gentile and Anna Young for donating their time to design and create the hanging shell art installation. Thanks to Ashley Peterson for assistance with generating exhibit materials, and to the many Oregon Coast Aquarium staff and volunteers for assistance with exhibit setup, installation, and maintenance. Thanks to Katy Nalven for guidance on the project, and to Amy Ehrhart, Dorothy Horn, Kaegan Scully-Engelmeyer and Katy Nalven for assistance with questionnaire data collection. Thanks to the Applied Coastal Ecology lab group for assistance with coding questionnaire data by theme and for input and support throughout the process. BB thanks her committee members Drs. Erin Shortlidge, Kathleen Conn, and Eugene Foster for their extensive and thoughtful input and guidance throughout the process. 


\subsection{References:}

Andrady, A. L. 2011. Microplastics in the marine environment. Marine Pollution Bulletin 62: 1596-1605. doi:10.1016/j.marpolbul.2011.05.030

Association of Zoos \& Aquariums. 2020. Visitor demographics: Who is visiting zoos and aquariums? Accessed April 22, 2020 from: https://www.aza.org/partnerships-visitor-demographics

Auta, H. S., C. U. Emenike, and S. H. Fauziah. 2017. Distribution and importance of microplastics in the marine environment: A review of the sources, fate, effects, and potential solutions. Environment International 102: 165-176. doi:10.1016/j.envint.2017.02.013

Ayres, R. and C. Melear. 1998. Increased Learning of Physical Science Concepts via Multimedia Exhibit Compared to Hands-on Exhibit in a Science Museum. Annual Meeting of the National Association for Research in Science Teachimg, San Diego, CA. Accessed April 20, 2020 from: https://files.eric.ed.gov/fulltext/ED418873.pdf

Baechler, B. R., E. F. Granek, M. V. Hunter, and K. E. Conn. 2020. Microplastic concentrations in two Oregon bivalve species: Spatial, temporal, and species variability. Limnology and Oceanography Letters 5: 54-65. doi:10.1002/lo12.10124

Ballantyne, R., J. Packer, K. Hughes, and L. Dierking. 2007. Conservation learning in 
wildlife tourism settings: lessons from research in zoos and aquariums.

Environmental Education Research 13: 367-383.

doi: $10.1080 / 13504620701430604$

Ballew, M. T., A. Leiserowitz, C. Roser-Renouf, and others. 2019. Climate Change in the American Mind: Data, Tools, and Trends. Environment: Science and Policy for Sustainable Development 61: 4-18. doi:10.1080/00139157.2019.1589300

Bamberg, S., and G. Möser. 2007. Twenty years after Hines, Hungerford, and Tomera: A new meta-analysis of psycho-social determinants of pro-environmental behaviour. Journal of Environmental Psychology 27: 14-25. doi:10.1016/j.jenvp.2006.12.002

Barnes, David K. A., Galgani Francois, Thompson Richard C., and Barlaz Morton. 2009. Accumulation and fragmentation of plastic debris in global environments. Philosophical Transactions of the Royal Society B: Biological Sciences 364: 1985-1998. doi:10.1098/rstb.2008.0205

Blud, L. M. 1990. Social interaction and learning among family groups visiting a museum. Museum Management and Curatorship 9: 43-51. doi:10.1080/09647779009515193

Borrelle, S. B., J. Ringma, K. L. Law, and others. 2020. Predicted growth in plastic waste exceeds efforts to mitigate plastic pollution. Science 369: 1515-1518. doi:10.1126/science.aba3656

Briseño-Garzón, A., D. Anderson, and A. Anderson. 2007. Adult Learning Experiences 
from an Aquarium Visit: The role of Social Interactions in Family Groups.

Curator: The Museum Journal 50: 299-318. doi:10.1111/j.21516952.2007.tb00274.x

Bullock, O. M., D. Colón Amill, H. C. Shulman, and G. N. Dixon. 2019. Jargon as a barrier to effective science communication: Evidence from metacognition. Public Underst Sci 28: 845-853. doi:10.1177/0963662519865687

Chase, N. L., Dominick, G. M., Trepal, A., Bailey, L. S., and D. B. Friedman. 2009. “This Is Public Health: Recycling Counts!” Description of a Pilot Health Communications Campaign. International Journal of Environmental Research and Public Health 6: 2980-2991. doi:10.3390/ijerph6122980.

Cohen, U. 1987. Learning from Children's museums: Implications for design. Children's Environments Quarterly 4: 16-23.

Cole, M., P. Lindeque, C. Halsband, and T. S. Galloway. 2011. Microplastics as contaminants in the marine environment: A review. Marine Pollution Bulletin 62: 2588-2597. doi:10.1016/j.marpolbul.2011.09.025

Derraik, J. G. B. 2002. The pollution of the marine environment by plastic debris: a review. Marine Pollution Bulletin 44: 842-852. doi:10.1016/S0025$\underline{326 \mathrm{X}(02) 00220-5}$

Diamond, J. 1986. The Behavior of Family Groups in Science Museums. Curator: The Museum Journal 29: 139-154. doi:10.1111/j.2151-6952.1986.tb01434.x

Ellenbogen, K. M., J. J. Luke, and L. D. Dierking. 2004. Family learning research in 
museums: An emerging disciplinary matrix? Science Education 88: S48-S58. doi: $10.1002 /$ sce.20015

Eriksen, M., L. C. M. Lebreton, H. S. Carson, and others. 2014. Plastic Pollution in the World's Oceans: More than 5 Trillion Plastic Pieces Weighing over 250,000 Tons Afloat at Sea. PLOS ONE 9: e111913. doi:10.1371/journal.pone.0111913

Falk, J. H. 1982. The Use of Time as a Measure of Visitor Behavior and Exhibit Effectiveness. Roundtable Reports 7: 10-13. Accessed April 22, 2020 from: https://www.jstor.org/stable/40479747?seq=1

Falk, J. H., and L. M. Adelman. 2003. Investigating the impact of prior knowledge and interest on aquarium visitor learning. Journal of Research in Science Teaching 40: 163-176. doi: $10.1002 /$ tea.10070

Falk, J. H., and L. D. Dierking. 1992. The museum experience. Washington, DC: Whales back Books.

Falk, J. H., and L. D. Dierking. 2000. Learning from museums: Visitor experiences and the making of meaning. Walnut Creek, CA: Alta Mira Press.

Frumkin, H., L. Fried, and R. Moody. 2012. Aging, Climate Change, and Legacy Thinking. Am J Public Health 102: 1434-1438. doi:10.2105/AJPH.2012.300663

Hartley, B. L., R. C. Thompson, and S. Pahl. 2015. Marine litter education boosts children's understanding and self-reported actions. Marine Pollution Bulletin 90: 209-217. doi:10.1016/j.marpolbul.2014.10.049

Heidbreder, L. M., I. Bablok, S. Drews, and C. Menzel. 2019. Tackling the plastic 
problem: A review on perceptions, behaviors, and interventions. Science of The Total Environment 668: 1077-1093. doi:10.1016/j.scitotenv.2019.02.437

Hohn, S., E. Acevedos-Trejos, J. F. Abrams, J. F. de Moura, R. Spranz, and A. Merico. 2020. The long-term legacy of plastic mass production. Science of The Total Environment 141115. doi:10.1016/j.scitotenv.2020.141115

Jambeck, J. R., R. Geyer, C. Wilcox, T. R. Siegler, M. Perryman, A. Andrady, R. Narayan, and K. L. Law. 2015. Plastic waste inputs from land into the ocean. Science 347: 768-771. doi:10.1126/science.1260352

Jensen, E. A., A. Moss, and M. Gusset. 2017. Quantifying long-term impact of zoo and aquarium visits on biodiversity-related learning outcomes. Zoo Biology 36: 294297. doi: $10.1002 /$ zoo. 21372

Johnson, B., and J. Kubarek. 2019. Summary of Evaluation Findings: Oregon Coast Aquarium Visitor Research. PEER Associates. Downloaded April 22, 2020 from: https://peerassociates.net/productsarchive

Kathryn Owen Consulting. 2015. Secrets of Shipwrecks Summative Evaluation. Prepared for Oregon Coast Aquarium. Unpublished report.

Knussen, C., and F. Yule. 2008. "I'm Not in the Habit of Recycling": The Role of Habitual Behavior in the Disposal of Household Waste. Environment and Behavior 40: 683-702. doi:10.1177/0013916507307527

Korkala, E. A. E., Hugg, T. T., and J. J. K. Jaakkola. 2014. Awareness of Climate Change and the Dietary Choices of Young Adults in Finland: A Population-Based CrossSectional Study. PLoS One 9. doi:10.1371/journal.pone.0097480. 
Kormos, C., and R. Gifford. 2014. The validity of self-report measures of proenvironmental behavior: A meta-analytic review. Journal of Environmental Psychology 40: 359-371. doi:10.1016/j.jenvp.2014.09.003

Kühn, S., E. L. Bravo Rebolledo, and J. A. van Franeker. 2015. Deleterious effects of litter on marine life, p. 75-116. In M. Bergmann, L. Gutow, and M. Klages [eds.], Marine Anthropogenic Litter. Springer International Publishing.

Lau, W. W. Y., Y. Shiran, R. M. Bailey, and others. 2020. Evaluating scenarios toward zero plastic pollution. Science. doi:10.1126/science.aba9475

Leisher, C., Mangubhai, S., Hess, S., Widodo, H., Soekirman, T., S. Tjoe, and others. 2012. Measuring the benefits and costs of community education and outreach in marine protected areas. Marine Policy 36: 1005-1011. doi:10.1016/j.marpol.2012.02.022

Lynn, H., Rech, S., and M. Samwel. 2017. Plastics, gender and the environment. Women Engage for a Common Future. ISBN 978-3-9813170-8-4. Accessed April 24, 2020 from: https://www.wecf.org/wpcontent/uploads/2018/11/PlasticsgenderandtheenvironmentHighRes-min.pdf

Moussouri, T. 1997. Family agendas and family learning in hands-on museums. Unpublished doctoral dissertation, University of Leicester, Leicester, U.K.

Nalven, K. B. 2019. Adapting the Community Based Social Marketing Framework to Create Actionable Messages About Plastic Pollution at the Oregon Coast Aquarium. Unpublished master's thesis, Oregon State University, Corvallis, Oregon, U.S. 
Nielsen, T. D., J. Hasselbalch, K. Holmberg, and J. Stripple. 2020. Politics and the plastic crisis: A review throughout the plastic life cycle. WIREs Energy and Environment 9: e360. doi: $10.1002 /$ wene. 360

Napper, I. E., and Thompson, R. C. 2020. Plastic Debris in the Marine Environment: History and Future Challenges. Global Challenges. doi:10.1002/gch2.201900081

Ohtomo, S., and S. Ohnuma. 2014. Psychological interventional approach for reduce resource consumption: Reducing plastic bag usage at supermarkets. Resources, Conservation and Recycling 84: 57-65. doi:10.1016/j.resconrec.2013.12.014

Pahl, S., and K. J. Wyles. 2017. The human dimension: how social and behavioural research methods can help address microplastics in the environment. Analytical Methods 9: 1404-1411. doi:10.1039/C6AY02647H

Phelan, A., H. Ross, N. A. Setianto, K. Fielding, and L. Pradipta. 2020. Ocean plastic crisis-Mental models of plastic pollution from remote Indonesian coastal communities. PLOS ONE 15: e0236149. doi:10.1371/journal.pone.0236149

R Core Team. 2020. R: A language and environment for statistical computing. R Foundation for Statistical Computing, Vienna, Austria. URL https://www.Rproject.org/

Reinhart, J. 2018. Global Warming Age Gap: Younger Americans Most Worried. Accessed April 24, 2020 from: https://news.gallup.com/poll/234314/globalwarming-age-gap-younger-americans-worried.aspx

Ross, S. R., and K. L. Gillespie. 2009. Influences on visitor behavior at a modern immersive zoo exhibit. Zoo Biology 28: 462-472. doi: $10.1002 /$ zoo.20220 
Schnurr, R. E. J., V. Alboiu, M. Chaudhary, and others. 2018. Reducing marine pollution from single-use plastics (SUPs): A review. Marine Pollution Bulletin 137: 157171. doi:10.1016/j.marpolbul.2018.10.001

Shulman, H. C., G. N. Dixon, O. M. Bullock, and D. Colón Amill. 2020. The Effects of Jargon on Processing Fluency, Self-Perceptions, and Scientific Engagement. Journal of Language and Social Psychology 0261927X20902177. doi: $10.1177 / 0261927 X 20902177$

Storksdieck, M., K. Ellenbogen, and J. E. Heimlich. 2005. Changing minds? Reassessing outcomes in free-choice environmental education. Environmental Education Research 11: 353-369. doi:10.1080/13504620500081228

Sujata, M., Khor, K.-S., Ramayah, T., and A. P. Teoh. 2019. The role of social media on recycling behaviour. Sustainable Production and Consumption 20: 365-374. doi: $10.1016 /$ j.spc.2019.08.005.

Tolmie, P., S. Benford, C. Greenhalgh, T. Rodden, and S. Reeves. 2014. Supporting group interactions in museum visiting. Proceedings of the 17th ACM conference on Computer supported cooperative work \& social computing. Association for Computing Machinery. 1049-1059.

Veiga, J. M., T. Vlachogianni, S. Pahl, and others. 2016. Enhancing public awareness and promoting co-responsibility for marine litter in Europe: The challenge of MARLISCO. Marine Pollution Bulletin 102: 309-315. doi:10.1016/j.marpolbul.2016.01.031

Vince, J., and P. Stoett. 2018. From problem to crisis to interdisciplinary solutions: 
Plastic marine debris. Marine Policy 96: 200-203.

doi:10.1016/j.marpol.2018.05.006

Yalowitz, S. S., and K. Bronnenkant. 2009. Timing and Tracking: Unlocking Visitor Behavior. Visitor Studies 12: 47-64. doi:10.1080/10645570902769134

Zelezny, L. C., P.-P. Chua, and C. Aldrich. 2000. New Ways of Thinking about Environmentalism: Elaborating on Gender Differences in Environmentalism. Journal of Social Issues 56: 443-457. doi:10.1111/0022-4537.00177 


\section{Chapter 5: Conclusions}

A growing body of literature characterizes microplastics (MPs) as harmful to the organisms and ecosystems they pervade (Barnes et al. 2009; Lusher et al. 2017). The research contained in Chapters 2 and 3 of this dissertation greatly improves our scientific understanding of MP prevalence in two prized Pacific Northwest (PNW) seafood species, the Pacific oyster (Crassostrea gigas) and Pacific razor clam (Siliqua patula). Our research confirms MPs are present in Pacific oysters and Pacific razor clams at all 23 sites sampled in Oregon (OR) and Washington (WA). It highlights the prevalence of MPs in the coastal environment, even in an area of relatively low human impact like the Olympic Coast, WA. Prior to this work, data had not been collected on MPs in Pacific razor clams anywhere in the world, and data on MP burdens in OR Pacific oysters were also absent.

We found OR Pacific oysters contained more MPs per individual and per gram of tissue than OR Pacific razor clams at our 15 study sites. In Pacific oysters purchased from six OR aquaculture growers, season influenced MP concentrations in Pacific oysters more than geography, body size or the anatomical differentiation between gut and tissue, with spring-collected individuals containing more MPs than summer-collected individuals and oysters containing more MPs than razor clams (Chapter 2; Baechler et al. 2020b). While not directly investigated, we posited that seasonal and species-specific MP differences may have been attributed to habitat (oysters inhabit estuarine environments, which receive stormwater runoff and wastewater inputs before the open coast-dwelling razor clams do; therefore, MPs may be more concentrated in estuaries), seasonal 
precipitation patterns (higher precipitation in spring than summer, resulting in higher levels of MP-laden runoff reaching coastal organisms), or the type of clothing laundered in the spring vs summer (bulkier synthetics used and laundered in the spring due to colder temperatures). A few OR site-specific differences in MPs were detected in oysters but not razor clam samples.

Investigations of Olympic Coast, WA Pacific razor clams allowed us to determine MP burdens were lower per individual (MP/individual) than those in OR razor clams but were similar when comparing MP/g $\mathrm{g}^{-1}$ tissue between the two states (Chapter 3). Polyethylene Terephthalate (PET), one of the most widely produced polymers in the world (33 million metric tons produced in 2015; Geyer et al. 2017) and commonly used in beverage containers and textiles, was the most frequently identified material in the subset of MPs chemically examined through Fourier Transform Infrared (FTIR) in both our OR and WA shellfish samples. The PET microfibers isolated from PNW shellfish samples investigated in Chapters 2 and 3 could have originated from numerous landbased sources including stormwater runoff and wastewater treatment plant effluent, but could also be derived from fishing-related activities including lost or abandoned fishing gear or associated ropes or lines (Chapter 1, Figure 1). While resin type was able to be determined through the use of Fourier Transform Infrared (FTIR), the specific origin of PET and other materials found in Pacific oysters and Pacific razor clams analyzed through this work could not be determined.

MP presence in Pacific Northwest (PNW) coastal food webs raises concern about the potential for ecological harm at numerous trophic levels. MPs in marine species 
harvested and sold for human consumption could pose threats to human health. While we do know that humans ingest MPs (through inhalation or direct consumption), our understanding of specific impacts to key human endpoints (growth, reproduction, cognitive abilities, fitness) are limited (Smith et al. 2018; Yong et al. 2020). Our estimates of MP exposure from razor clams by Olympic Coast harvester-consumers were 60-3,070 MP/yr for cleaned or 120-6,020 MP/yr for whole clams, illustrating the importance of cleaning clams prior to consumption to reduce human MP exposure. We identified significant differences in harvester-consumer MP exposure based on gender and ethnicity. Due to the low sample size of Alaska Native and Native American questionnaire respondents in Chapter 3, we are unable to broadly generalize about clam consumption frequencies of individuals within these groups; however, responses we obtained from these few individuals were striking considering the much higher minimum exposure level of MPs through razor clam consumption than other ethnicities. Owing to this finding and previous reports that seafood consumption tendencies vary by ethnicity (e.g., Sechena et al. 1999; Mahaffey et al. 2009; EPA 2014; Cisneros-Montemayor et al. 2016), additional PNW-specific research regarding seafood consumption and subsequent microplastic exposure for these and other high-seafood consumer demographics is important and necessary.

Reducing exposure is particularly important in the absence of established safety thresholds for human MP intake. Fortunately, Olympic Coast razor clams appear to be a minimal vector of MP exposure within the recreational razor clam harvester-consumer group studied when compared to other known exposure routes of MPs to humans (e.g., 
inhalation, deposition of microfibers during meals, consumption of table salt or drinking bottled water; Catarino et al. 2018; Cox et al. 2019; Zhang et al. 2020a).

We identified a knowledge gap in the group of WA razor clam harvesters studied, whereby most of these direct resource users in our study did not possess knowledge about MP contamination in food items, but nonetheless harbored concerns about the concept (Chapter 3). Educating the public, including fishers and direct resource users, through campaigns or passive outreach (e.g., through aquarium exhibits) could be an effective means to disseminate MP information to broad audiences and promote future plasticrelated environmental stewardship actions.

The OR Coast Aquarium ocean plastic exhibit designed, installed and evaluated as an educational tool (Chapter 4), demonstrated information transfer to aquarium visitors and helped elicit self-reported intent to change single-use plastic behaviors by those visitors. Visitors reported learning from exhibit engagement and communicated willingness to change behaviors in their daily lives to reduce single-use plastic items. Nearly $40 \%$ of aquarium questionnaire respondents were receptive to changing some actions- namely using reusable straws, cleaning the beach, carrying utensils and bringyour-own (BYO) bag to the store or market. Providing simple, effective guidance on ways to effectively implement these changes in daily life may facilitate adoption of those actions, as visitors reported interest and intent to change these actions and may be on the cusp of doing so. Conversely, respondents were unlikely to propose changing how frequently they carry a reusable water bottle, specifically choose items not packaged in plastic, contact companies or representatives, and BYO containers to a restaurant. 
Providing concise, engaging, and widely available information on how these actions can ultimately lead to a reduction in ocean plastic could move the dial on household singleuse plastic reduction via employment of these actions.

The data generated in this dissertation on MP prevalence in shellfish, MP exposure through harvest and consumption of said shellfish, MP knowledge and concerns of recreational razor clammers and aquarium visitors, and single-use plastic behavioral change opportunities, has advanced the existing scientific knowledge base regarding the issue of marine plastics in the PNW. Results of this work have been disseminated to a variety of audiences throughout the PNW and more broadly through oral and poster presentations at scientific conferences, in classrooms and at informal pub events, through publications, installation of an educational aquarium exhibit, and via mainstream media coverage. I hope the array of techniques used to communicate these results will reach broad audiences in the PNW and beyond, inspiring current and future leaders to tackle the plastic pollution issue head-on in our region and around the world.

Ocean plastic pollution is an ever-growing issue that requires, among a suite of other interventions, education to inspire behavioral change and meaningfully reduce would-be future ocean plastic pollution. In addition to behavioral change, upstream reductions to plastic production, and improvements to better manage plastic waste and plastic breakdown products like MPs are critical to prevent pollution from reaching coasts and oceans (Chapter 1, Figure 2). This body of work highlights the issue of MP incorporation in two important PNW bivalve species, and also illuminates the ways in which Oregon Coast Aquarium visitors employ and are willing to change their single-use 
plastic actions to reduce ocean plastic pollution. The results of my work contained in Chapters 2-4 can inform waste management, engineering solutions, and policy actions to reduce MP transmission into the ocean, and drive individual behavioral shifts that reduce single-use plastic dependency, ultimately leading to long-lasting positive change. Due to repeated findings of MPs in marine species worldwide, the need to overhaul our current microplastic management and mitigation practices is apparent. We must modify our extant technologies and behaviors appropriately to reduce future transmission of MPs, and in particular microfibers, into the environment. A focus on land-based solutions to MP pollution is imperative, as more than $80 \%$ of primary and secondary MPs originate on land (Miranda et al. 2019). The laundering of clothing is a significant vector of anthropogenic microfibers to the environment; since the 1950's, over 5.9 million metric tons of synthetic MPs have been generated through laundering (Gavigan et al. 2020). Our findings of primarily microfibers in PNW bivalves highlights a need for upstream microfiber pollution control at the source, such as integrating MP capture technologies into washing machines- a technology that will be required in France beginning in 2025 (European Parliament 2020). Broader adoption of similar technologies by the United States and other countries could drastically reduce global microfiber emissions to the environment moving forward.

This and similar works will be important references for future MP source reduction regulations, human toxicological risk assessments for the numerous MP categories, shapes, sizes, material types, and colors, and perhaps establishing human health standards, which are currently defined for many chemical contaminants but 
unknown for MPs. Ultimately, it will be important for us as a society to not only prioritize research and impacts of MPs on marine species and humans, but to effect sustained behavioral changes and enact policies that meaningfully prevent these harmful pollutants from becoming further incorporated into food webs and the human diet. The actions we take today to abate further transmission of plastics into the environment will help preserve ocean health and protect the innumerable, indispensable resources and ecosystem services our global ocean provides. 


\subsection{References:}

Baechler, B. R., C. D. Stienbarger, D. A. Horn, J. Joseph, A. R. Taylor, E. F. Granek, and S. M. Brander. 2020a. Microplastic occurrence and effects in commercially harvested North American finfish and shellfish: Current knowledge and future directions. Limnology and Oceanography Letters 5: 113-136. doi:10.1002/lol2.10122

Baechler, B. R., E. F. Granek, M. V. Hunter, and K. E. Conn. 2020b. Microplastic concentrations in two Oregon bivalve species: Spatial, temporal, and species variability. Limnology and Oceanography Letters 5: 54-65. doi:10.1002/lol2.10124

Barnes, David K. A., Galgani Francois, Thompson Richard C., and Barlaz Morton. 2009. Accumulation and fragmentation of plastic debris in global environments. Philosophical Transactions of the Royal Society B: Biological Sciences 364: 1985-1998. doi:10.1098/rstb.2008.0205

Catarino, A. I., V. Macchia, W. G. Sanderson, R. C. Thompson, and T. B. Henry. 2018. Low levels of microplastics (MP) in wild mussels indicate that MP ingestion by humans is minimal compared to exposure via household fibres fallout during a meal. Environmental Pollution 237: 675-684. doi:10.1016/j.envpol.2018.02.069

Cisneros-Montemayor, A. M., Pauly, D., Weatherdon, L. V., and Ota, Y. (2016). A Global Estimate of Seafood Consumption by Coastal Indigenous Peoples. PLoS One 11. doi:10.1371/journal.pone.0166681. 
Cox, K. D., G. A. Covernton, H. L. Davies, J. F. Dower, F. Juanes, and S. E. Dudas. 2019. Human Consumption of Microplastics. Environ. Sci. Technol. 53: 70687074. doi:10.1021/acs.est.9b01517

European Parliament. (2020). Parliamentary questions: Plastic microfibre filters for new washing machines by 2025. Accessed September 20, 2020 from: https://www.europarl.europa.eu/doceo/document/E-9-2020001371_EN.html\#: :text=France\%20has\%20just\%20adopted\%20a,away\%20fro m\%20clothing\%20during\%20washing.

Gavigan, J., T. Kefela, I. Macadam-Somer, S. Suh, and R. Geyer. 2020. Synthetic microfiber emissions to land rival those to waterbodies and are growing. PLOS ONE 15: e0237839. doi:10.1371/journal.pone.0237839

Geyer, R., J. R. Jambeck, and K. L. Law. 2017. Production, use, and fate of all plastics ever made. Science Advances 3: e1700782. doi:10.1126/sciadv.1700782

Lusher, A., P. Hollman, and J. Mendoza-Hill. 2017. Microplastics in fisheries and aquaculture: Status of knowledge on their occurrence and implications for aquatic organisms and food safety. FAO Fisheries and Aquaculture Technical Paper; Rome.

Mahaffey Kathryn R., Clickner Robert P., and Jeffries Rebecca A. (2009). Adult Women's Blood Mercury Concentrations Vary Regionally in the United States: Association with Patterns of Fish Consumption (NHANES 1999-2004). Environmental Health Perspectives 117, 47-53. doi:10.1289/ehp.11674 
Miranda, M. N., A. M. T. Silva, and M. F. R. Pereira. 2020. Microplastics in the environment: A DPSIR analysis with focus on the responses. Science of The Total Environment 718: 134968. doi: $10.1016 / j . s c i t o t e n v .2019 .134968$

Sechena, R., Nakano, C., Liao, S., Polissar, N., Lorenzana, R., Truong, S., \& Fenske, R. (1999). Asian and Pacific Islander seafood consumption study. EPA Office of Environmental Assessment, 1-169.

Smith, M., D. C. Love, C. M. Rochman, and R. A. Neff. 2018. Microplastics in Seafood and the Implications for Human Health. Curr Envir Health Rpt 5: 375-386. doi: $10.1007 / \mathrm{s} 40572-018-0206-\mathrm{Z}$

Yong, C. Q. Y., S. Valiyaveetill, and B. L. Tang. 2020. Toxicity of Microplastics and Nanoplastics in Mammalian Systems. IJERPH 17: 1509. doi:10.3390/ijerph17051509

Zhang, Q., E. G. Xu, J. Li, Q. Chen, L. Ma, E. Y. Zeng, and H. Shi. 2020. A Review of Microplastics in Table salt, Drinking Water, and Air: Direct Human Exposure. Environ. Sci. Technol. doi:10.1021/acs.est.9b04535 


\section{Appendices:}

APPENDIX A: CHAPTER 2. Biological information for Pacific oysters and razor clams collected at each sample site in April (Spring) and July (Summer) 2017.

\begin{tabular}{|c|c|c|c|c|c|c|c|}
\hline \multirow[b]{2}{*}{ Spp. } & \multirow[b]{2}{*}{ Site name } & \multicolumn{3}{|c|}{ Spring 2017} & \multicolumn{3}{|c|}{ Summer 2017} \\
\hline & & $\begin{array}{l}\text { Avg. shell length } \\
\text { in mm (SE) }\end{array}$ & $\begin{array}{l}\text { Avg. shell } \\
\text { width in mm } \\
\text { (SE) }\end{array}$ & $\begin{array}{l}\text { Body tissue wet } \\
\text { weight in } g(\mathrm{SE})\end{array}$ & $\begin{array}{c}\text { Avg. shell length } \\
\text { in } \mathrm{mm} \text { (SE) } \\
\end{array}$ & $\begin{array}{l}\text { Avg. shell } \\
\text { width in mm } \\
\text { (SE) }\end{array}$ & $\begin{array}{l}\text { Body tissue } \\
\text { wet wt in } g \\
\text { (SE) }\end{array}$ \\
\hline \multirow{6}{*}{ 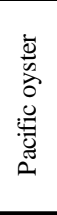 } & OY1 & $111.75(2.32)$ & $60.56(1.59)$ & $26.96(1.88)$ & $112.21(2.00)$ & $66.68(3.12)$ & $24.10(2.95)$ \\
\hline & OY2 & $156.03(5.86)$ & $66.64(2.48)$ & $32.52(1.82)$ & $132.94(4.43)$ & $74.02(4.43)$ & $34.22(2.49)$ \\
\hline & OY3 & $121.77(3.01)$ & $65.55(2.29)$ & $24.06(1.28)$ & $133.18(5.94)$ & $68.44(2.68)$ & $32.76(1.76)$ \\
\hline & OY4 & $134.11(3.76)$ & $83.24(4.36)$ & $46.96(3.54)$ & $133.32(3.30)$ & $78.33(3.29)$ & $51.30(6.23)$ \\
\hline & OY5 & $119.79(1.81)$ & $62.87(1.53)$ & $19.15(0.57)$ & $100.56(5.27)$ & $51.49(3.08)$ & $19.12(4.59)$ \\
\hline & OY6 & $114.90(2.27)$ & $76.73(1.98)$ & $34.74(2.36)$ & $124.09(6.36)$ & $57.74(2.78)$ & $25.70(2.21)$ \\
\hline \multirow{9}{*}{ 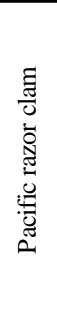 } & Clatsop Beach & $112.99(2.12)$ & $43.68(1.20)$ & $56.24(3.50)$ & $108.76(1.51)$ & $43.06(0.46)$ & $57.65(2.02)$ \\
\hline & Cannon Beach & $118.89(4.49)$ & $46.61(2.60)$ & $55.60(5.73)$ & $110.34(1.84)$ & $43.30(1.40)$ & $59.22(3.44)$ \\
\hline & Cape Meares & $112.65(2.79)$ & $45.24(1.68)$ & $49.45(3.80)$ & $84.81(7.39)$ & $32.88(3.45)$ & $26.24(7.41)$ \\
\hline & Agate Beach & N/A & N/A & N/A & $121.41(1.49)$ & $48.83(0.73)$ & $68.72(1.78)$ \\
\hline & Newport S. Beach & $114.78(1.42)$ & $48.12(1.23)$ & $45.91(2.14)$ & $120.20(1.96)$ & $49.41(1.10)$ & $71.44(3.60)$ \\
\hline & Coos Bay & $115.83(1.84)$ & $48.14(1.02)$ & $40.84(1.38)$ & N/A & N/A & N/A \\
\hline & Bastendorff Beach & N/A & N/A & N/A & $113.15(4.36)$ & $45.51(1.74)$ & $59.92(4.36)$ \\
\hline & Whiskey Creek & N/A & N/A & N/A & $117.19(1.47)$ & $48.65(1.14)$ & $63.28(4.43)$ \\
\hline & Gold Beach & N/A & N/A & N/A & $121.55(1.51)$ & $47.93(0.69)$ & $71.30(3.00)$ \\
\hline
\end{tabular}

Notes: $\quad$ Spp. $=$ Species; Avg. $=$ Average; $\mathrm{WT}=$ Weight; $\mathrm{SE}= \pm$ Standard Error; OY1-OY6: Oyster site (randomized).

APPENDIX B: CHAPTER 2. Sources, averages, and ranges of microplastic contamination in Pacific oyster and Pacific razor clam samples.

\begin{tabular}{|c|c|c|c|c|}
\hline $\begin{array}{c}\text { Sources of } \\
\text { microplastic } \\
\text { contamination }\end{array}$ & Description & $\begin{array}{c}\text { Pacific oysters } \\
\text { (Avg. per sample) }\end{array}$ & $\begin{array}{c}\text { Pacific razor clams } \\
\text { (Avg. per sample) }\end{array}$ & $\begin{array}{c}\text { Range of } \\
\text { microplastic counts } \\
\text { per sample }\end{array}$ \\
\hline Procedural controls & $\begin{array}{c}\text { Filtered DI water run through chemical } \\
\text { digestion, sieving, visual microscope } \\
\text { analysis }\end{array}$ & $4.91 \pm 1.11$ & $4.91 \pm 1.11$ & $0-10$ \\
\hline $\begin{array}{c}\text { Microscope blanks } \\
\text { to the air during microscope analysis } \\
\text { of regular samples. }\end{array}$ & $0.20 \pm 0.03$ & $0.20 \pm 0.03$ & $0-5$ \\
\hline $\begin{array}{c}\text { Secondary digestion } \\
\text { step (razor clams } \\
\text { only) }\end{array}$ & $\begin{array}{c}\text { Chemical digestion and hypersaline } \\
\text { density separation }\end{array}$ & Not undertaken & 1.00 microfiber per \\
sample & $1-1$ \\
\hline $\begin{array}{c}\text { TOTAL } \\
\text { Contamination }\end{array}$ & Sum of all sources of contamination & $\mathbf{5 . 1 1}$ & $\mathbf{6 . 1 1}$ & N/A \\
\hline
\end{tabular}

Notes: Avg. $=$ Average. 


\section{Chapter 3}

APPENDIX C: CHAPTER 3. 2010 Land use cover $\left(\mathrm{km}^{2}\right)$ for the four coastal counties located on the Olympic Peninsula, WA. Counties are ordered north to south. Razor clam sample site names are listed below their respective county names. No razor clam sites were located in Clallam county. Data was obtained from NOAA’s Digital Coast at: https://coast.noaa.gov/digitalcoast/tools/lca.html.

\begin{tabular}{|c|c|c|c|c|c|c|c|}
\hline \multirow[b]{2}{*}{ County } & \multicolumn{7}{|c|}{ Land Use cover (sq. km) } \\
\hline & Forested & Scrubland & Bare Land & Grassland & Wetland & Development & Agriculture \\
\hline $\begin{array}{l}\text { Clallam county } \\
\text { (no sites) }\end{array}$ & 3365 & 572 & 109 & 190 & 69 & 114 & 96 \\
\hline $\begin{array}{l}\text { Jefferson county } \\
\text { (Kalaloch beach) }\end{array}$ & 3556 & 461 & 376 & 158 & 93 & 49 & 19 \\
\hline $\begin{array}{l}\text { Grays Harbor count } \\
\text { (Point Grenville, } \\
\text { Mocrocks, } \\
\text { Copalis beach, } \\
\text { South Copalis, } \\
\text { North Twin Harbor, } \\
\text { South Twin Harbor) }\end{array}$ & 2973 & 976 & 250 & 355 & 284 & 119 & 107 \\
\hline $\begin{array}{l}\text { Pacific county } \\
\text { (Long Beach) }\end{array}$ & 1303 & 509 & 252 & 259 & 186 & 44 & 45 \\
\hline
\end{tabular}

APPENDIX D: CHAPTER 3. Schematic of the two microplastic (MP) contamination quantification techniques employed in this study. Procedural controls were deionized water filtered to $50 \mu \mathrm{m}$ and run through the same process as all other samples. Microscope blanks were glass petri dishes filled with filtered DI water, placed on the microscope base, and left open to the air during visual inspection of samples for MPs.

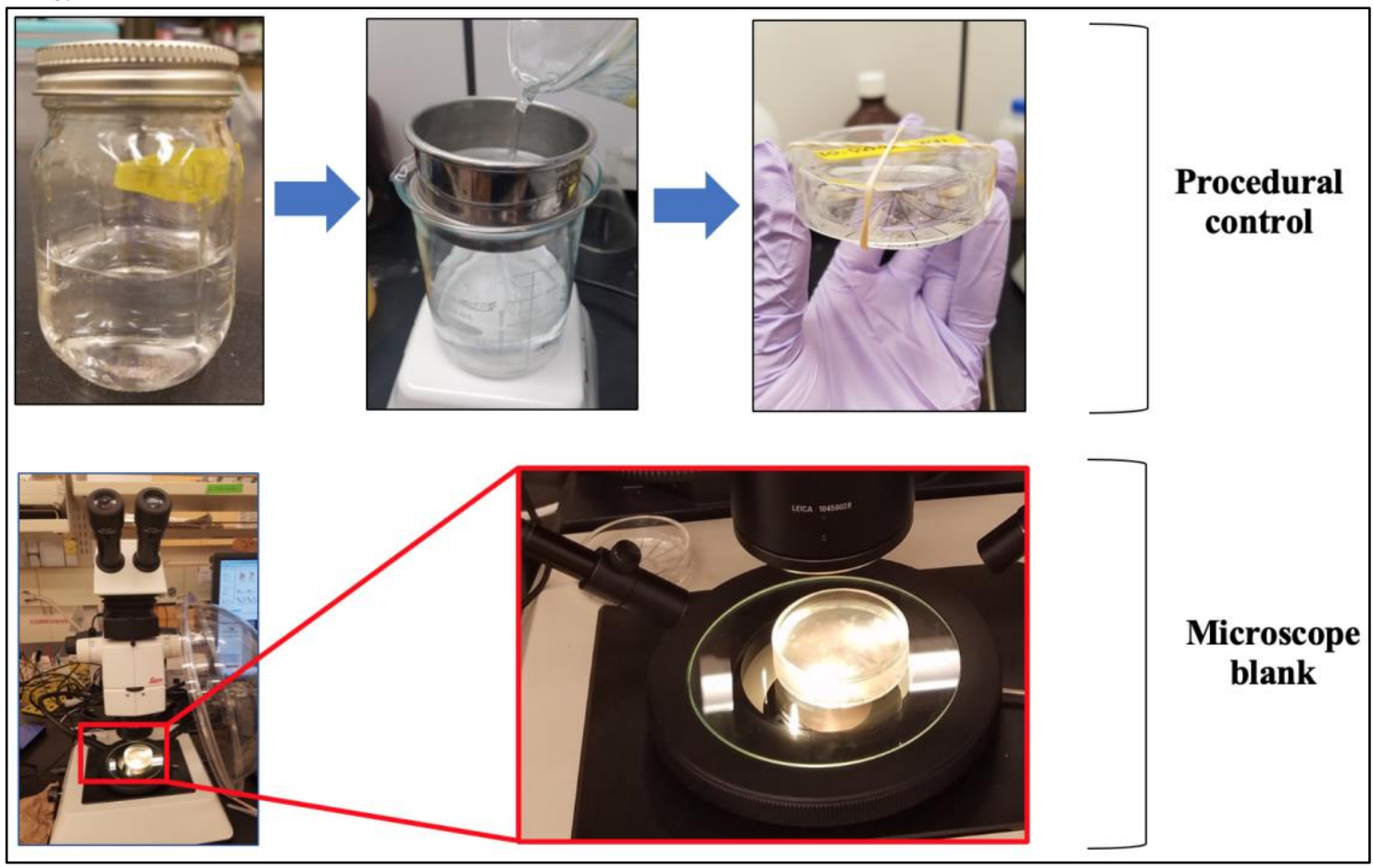


APPENDIX E: CHAPTER 3. Five-page structured questionnaire administered to Olympic Coast razor clam harvesters in April 2018 at Mocrocks and Copalis Beaches, Olympic Peninsula, Washington, United States.

\section{Portland State University Pacific Northwest Razor Clam, Shellfish \& Microplastics Survey}

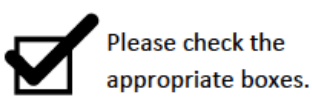

The information you provide is anonymous but will be made public after data is analyzed. If during the survey you feel uncomfortable or do not wish to proceed, you may end your participation at any time.

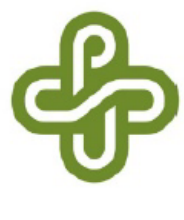

Q1: Are you 18 years of age or older?
$\square$ Yes
$\square$ No

Q2: In the past year, did you eat razor clams?
$\square$ Yes
$\square$ No
$\square$ I don't know

Q3: For each season within the past year, how often did you eat razor clams?

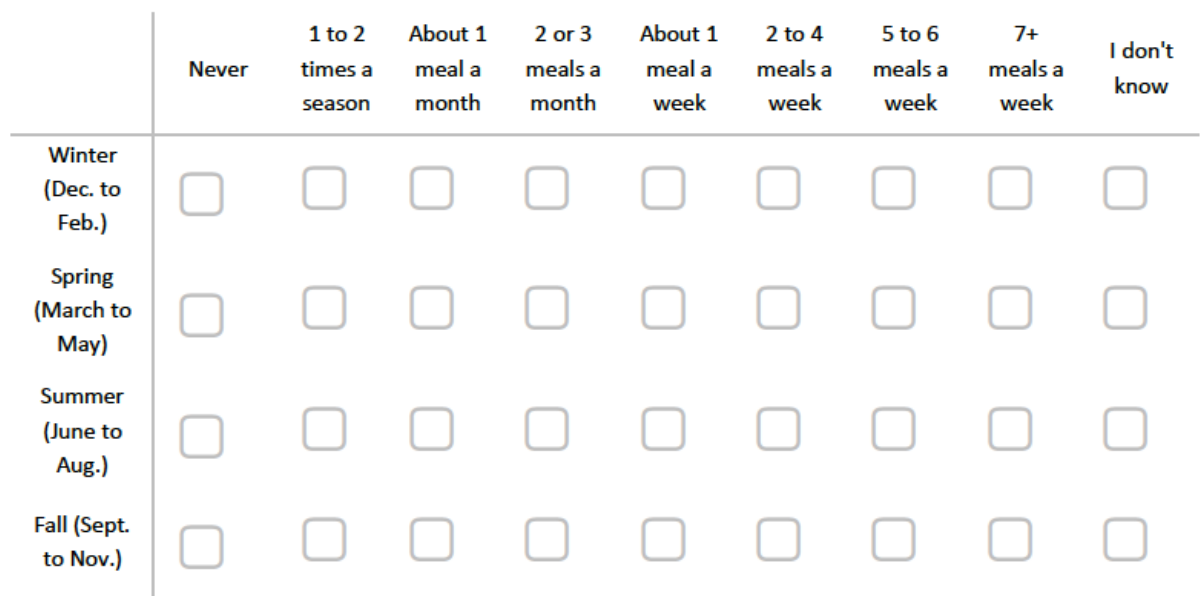

Q4: In the past year, for the meals that had clams, about how many did you eat in each sitting? This is an estimate of individual clams.

$\begin{array}{lll}\square 0 & \square 5 & \square 10 \\ \square 1 & \square 6 & \square 11 \\ \square 2 & \square 7 & \square 12 \\ \square 3 & \square 8 & \square 13+ \\ \square 4 & \square 9 & \end{array}$


Q5: Within the past year, when you consumed razor clams, you ate them:

$\square$ With guts

$\square$ Without guts

$\square$ Sometimes with guts, sometimes without

$\square$ I don't know

Q6: Your favorite preparation of razor clams is:

$\square$ Soup, Stew, or Chowder

$\square$ Pan or deep fried

$\square$ Smoked

$\square$ Other (write in):
Q7: Within the past year, how did you obtain the razor clams you ate? Select all that apply.

$\square$ I dug them myself

$\square$ Friends or family gave them to me

$\square$ I purchased them

$\square \mathrm{I}$ ate them at tribal events

$\square$ I traded or bartered for them

$\square$ Other (write in):

$\square$ I did not eat razor clams

$\square$ I don't know

Q8: For each season within the past year, how often did you collect or harvest razor clams?

Once a
month


Q9: Within the past year, roughly how often did you eat other marine shellfish species?

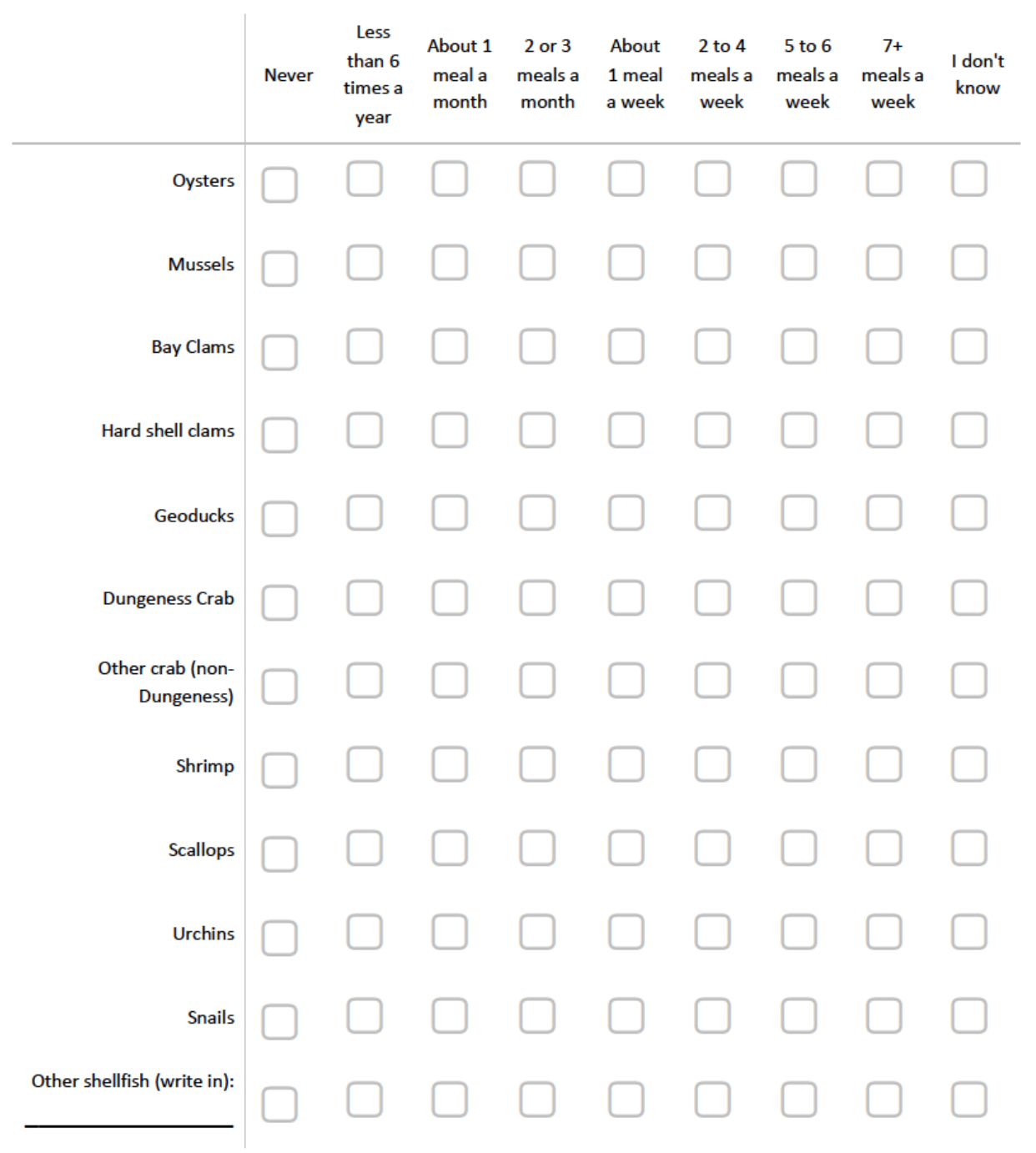

Page 3 of 5 
Q10: Within the past year, did you dig razor clams commercially (to sell)?

$\square$ Yes

$\square$ No

Q11: How familiar are you with the concept of microplastics in food?

$\square$ Not familiar at all

$\square$ Moderately familiar

$\square$ Very familiar

\section{Q12: Do you have any concerns about} microplastics in your food?

$\square$ Yes

$\square$ No

$\square$ I don't know

Q13: Please expand on what concerns you have about microplastics in your food.

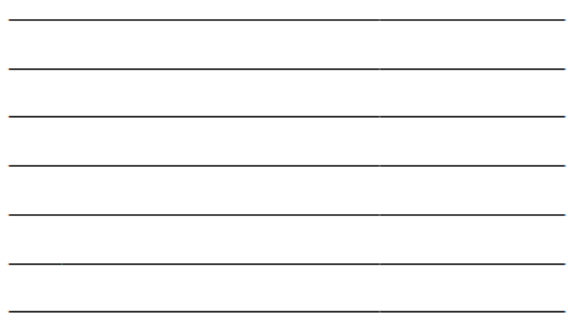

Q14: How old are you (in years)?

$\begin{array}{ll}\square 18-28 & \square 51-61 \\ \square 29-39 & \square 62+ \\ \square 40-50 & \end{array}$

Q15: What is your gender?

$\square$ Male $\quad \square$ Female $\quad \square$ Other

Q16: What is your ethnic identity? Select all that apply.

$\square$ Native American

$\square$ Alaska Native

$\square$ Native Hawaiian or Pacific Islander

$\square$ Black or African American

$\square$ Asian

$\square$ Latino

$\square$ White/Caucasian

$\square$ Other (write in):

Q17: What is/are your Tribal affiliation(s)? Select all that apply.

$\begin{array}{ll}\square \text { Alsea } & \square \text { Kwalhioqua } \\ \square \text { Chinook } & \square \text { Makah } \\ \square \text { Chehalis } & \square \text { Quileute } \\ \square \text { Clatskanie } & \square \text { Quinault } \\ \square \text { Coos } & \square \text { Siletz } \\ \square \text { Cowlitz } & \square \text { Siuslaw } \\ \square \text { Klallam } & \square \text { Tillamook } \\ \quad \square \text { Other (write in): } & \\ \quad \square \text { No tribal affiliation } & \end{array}$

Page 4 of 5 
Q18: Which county do you live in?

Washington
$\square$ Clallam
$\square$ Clark
$\square$ Cowlitz
$\square$ Grays Harbor
$\square$ Jefferson
$\square$ Pacific
$\square$ Wahkiakum

$\square$ Other (write in):

$\square$ I do not live in Washington or Oregon

Q19: What is your employment status?
$\square$ Full time
$\square$ Part time
$\square$ Self employed
$\square$ Retired
$\square$ Student
$\square$ Unemployed
$\square$ Other (write in):

Q20: In which sector are you employed?

$$
\begin{aligned}
& \square \text { Government } \\
& \square \text { Tribal } \\
& \square \text { Agriculture/Farming } \\
& \square \text { Fishing } \\
& \square \text { Education } \\
& \square \text { Retail } \\
& \square \text { Customer service } \\
& \square \text { Unemployed } \\
& \square \text { Retired } \\
& \square \text { Other (write in): }
\end{aligned}
$$

Q21: What is your estimated income per year from all sources (in US dollars)?

$$
\begin{aligned}
& \square \text { Less than } \$ 15,000 \\
& \square \$ 15,001-\$ 25,000 \\
& \square \$ 25,001-\$ 35,000 \\
& \square \$ 35,001-\$ 50,000 \\
& \square \$ 50,001-\$ 75,000 \\
& \square \$ 75,001-\$ 100,000 \\
& \square \$ 100,001-\$ 150,000 \\
& \square \text { More than } \$ 150,000
\end{aligned}
$$

Q22: What is your highest level of education completed?

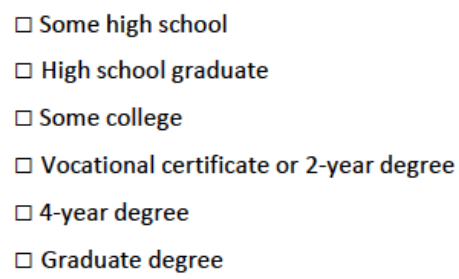

THANK YOU!

You have reached the end of the survey.

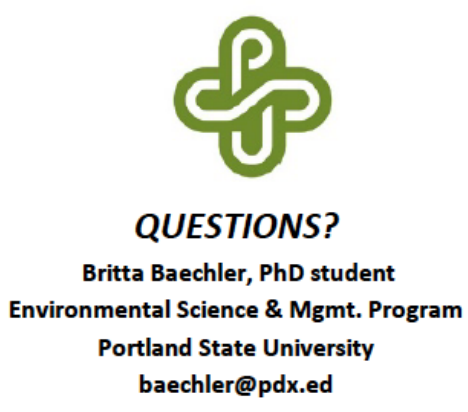


APPENDIX F: CHAPTER 3. Number and percentage of Olympic Coast questionnaire respondents that consumed marine shellfish species or species groups. Consumption frequency is ordered from most to least frequent.

\begin{tabular}{|c|c|c|c|c|c|c|c|c|c|c|c|}
\hline \multirow[b]{2}{*}{$\begin{array}{c}\text { Consumption } \\
\text { frequency }\end{array}$} & \multicolumn{6}{|c|}{ BIVALVES } & \multicolumn{3}{|c|}{ CRUSTACEANS } & \multirow{2}{*}{$\frac{\text { GASTROPODS }}{\text { Snails }}$} & \multirow{2}{*}{$\begin{array}{c}\text { ECHINODERMS } \\
\text { Urchins }\end{array}$} \\
\hline & Oysters & $\begin{array}{l}\text { Hardshell } \\
\text { clams }\end{array}$ & Scallops & Mussels & Bay clams & Geoducks & $\begin{array}{l}\text { Dungeness } \\
\text { crab }\end{array}$ & Shrimp & Other crab & & \\
\hline $7+$ meals/week & 2 & 0 & 1 & 0 & 0 & 0 & 0 & 1 & 0 & 0 & 0 \\
\hline 5 to 6 meals/week & 0 & 0 & 0 & 0 & 0 & 0 & 1 & 0 & 0 & 0 & 0 \\
\hline 2 to 4 meals/week & 2 & 2 & 1 & 2 & 2 & 1 & 2 & 6 & 1 & 0 & 0 \\
\hline About 1 meal/week & 1 & 1 & 0 & 0 & 0 & 0 & 2 & 6 & 2 & 0 & 0 \\
\hline 2 or 3 meals $/$ month & 3 & 1 & 6 & 2 & 4 & 0 & 6 & 19 & 1 & 0 & 0 \\
\hline About 1 meal/month & 9 & 7 & 8 & 5 & 4 & 0 & 14 & 24 & 7 & 0 & 0 \\
\hline$<6$ meals/year & 58 & 47 & 37 & 33 & 22 & 11 & 69 & 31 & 42 & 10 & 2 \\
\hline I don't know & 1 & 2 & 0 & 0 & 2 & 0 & 0 & 0 & 0 & 0 & o \\
\hline Never & 26 & 43 & 49 & 60 & 66 & 89 & 10 & 16 & 43 & 88 & 96 \\
\hline Total responses & 102 & 103 & 102 & 102 & 100 & 101 & 104 & 103 & 96 & 98 & 98 \\
\hline $\begin{array}{r}\text { Percentage of } \\
\text { consumers }^{1}\end{array}$ & $73.5 \%$ & $56.3 \%$ & $52.0 \%$ & $41.2 \%$ & $32.0 \%$ & $11.9 \%$ & $90.4 \%$ & $84.5 \%$ & $55.2 \%$ & $10.2 \%$ & $2.0 \%$ \\
\hline
\end{tabular}

Notes: ${ }^{1}$ Calculated as number of respondents that reported consuming a particular species or species group (i.e. all consumption frequencies except 'I don't know' and 'Never'), divided by total responses for that species or species group, multiplied by 100. 
APPENDIX G: CHAPTER 3. Example photos of suspected microplastics (MPs) extracted from Olympic Coast razor clams (top) and total counts of each MP category encountered (bottom) in the 4 razor clam sample types included in this study (whole, cleaned, gut-tissue only, tissue-only). Black bars represent a length of $0.5 \mathrm{~mm}$ in each of the images shown.
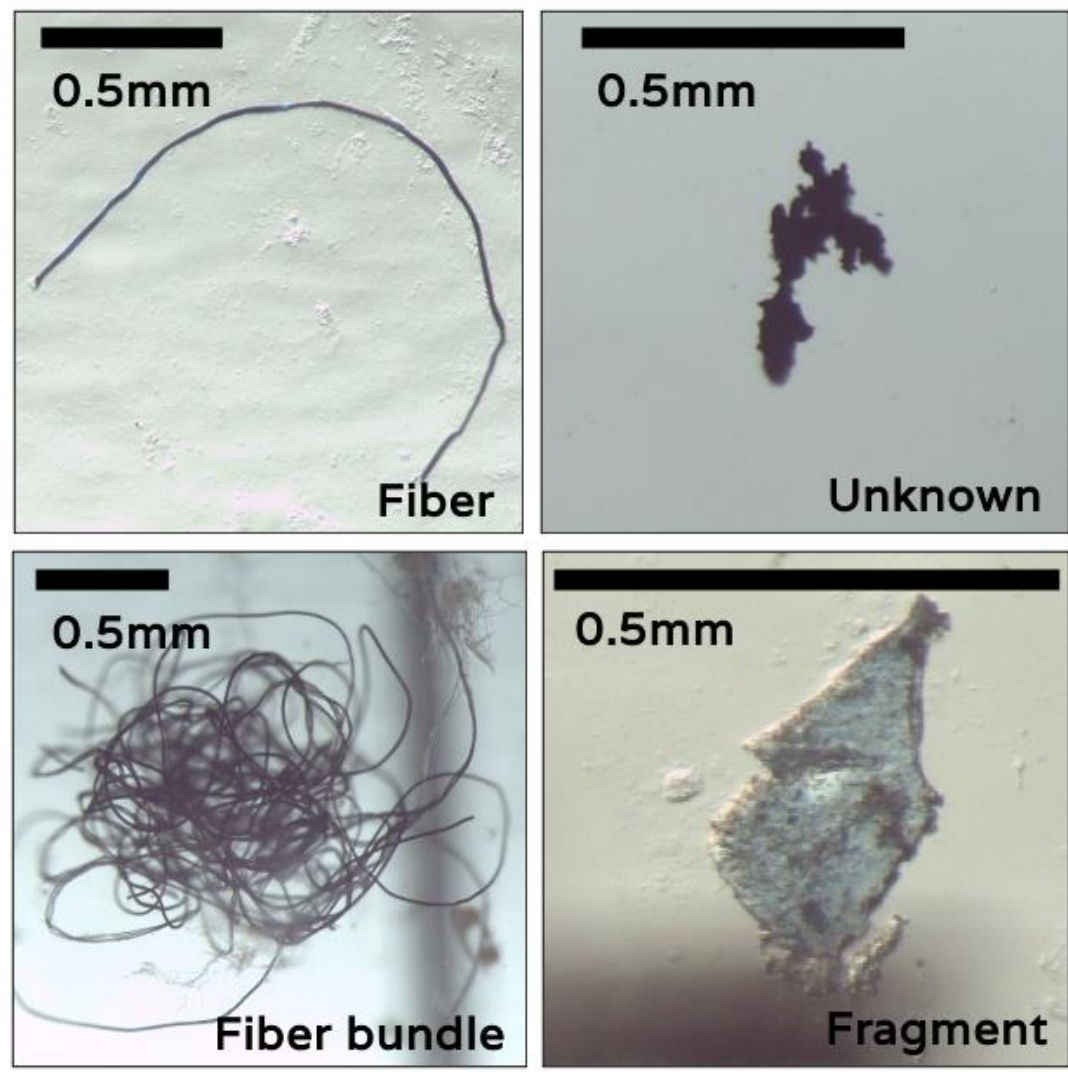

MP Category

Fiber

Unknown

Fiber bundle

Total \#

793

3

2

Fragment

1

Total

799 
APPENDIX H: CHAPTER 3. Numbers and percentages of suspected microplastics identified in 138 Olympic Coast razor clam samples $(\mathrm{n}=799)$ by color. Colors in figure correspond to actual colors encountered: colorless $(n=441 ; 55.19 \%)$, blue $(n=154 ; 19.27 \%)$, gray $(n=98 ; 12.27 \%)$, black $(n=37$; $4.63 \%)$, red $(\mathrm{n}=26 ; 3.25 \%)$, purple $(\mathrm{n}=19 ; 2.38 \%)$, brown $(\mathrm{n}=15 ; 1.88 \%)$, green $(\mathrm{n}=5 ; 0.63 \%)$, and pink $(\mathrm{n}=4 ; 0.50 \%)$.

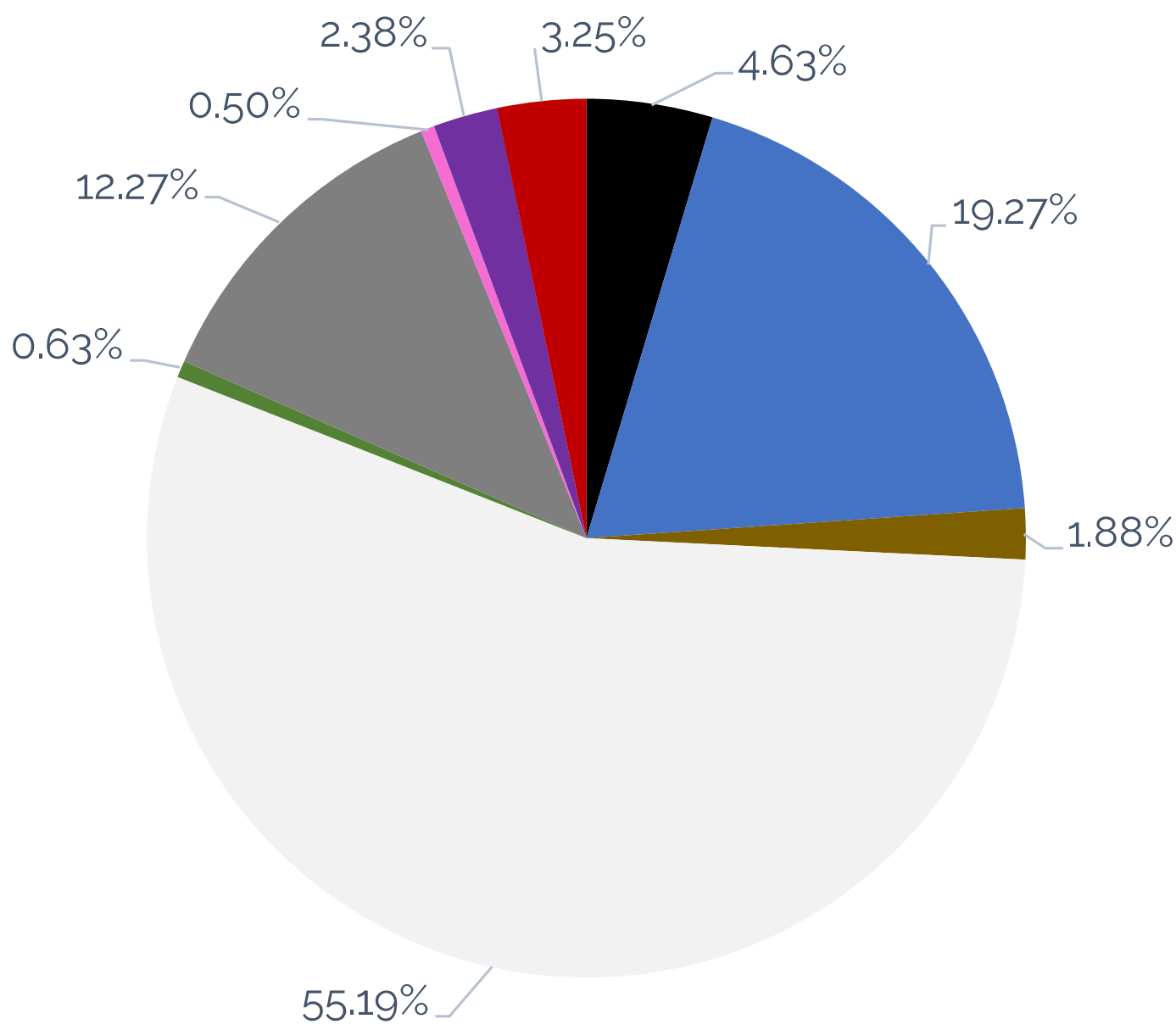


APPENDIX I: CHAPTER 3. Characteristics, material types and FTIR spectral match percentages for 53 randomly-selected suspected microplastics isolated from Olympic Coast razor clams. Results are sorted by FTIR \% top match from highest to lowest.

\begin{tabular}{|c|c|c|c|}
\hline Color & Length (mm) & Material type determined & FTIR \% match \\
\hline Red & 1.9 & Polyethylene terephthalate & $96.41 \%$ \\
\hline Gray & 3.2 & Cellulose acetate & $95.64 \%$ \\
\hline Brown & 1.3 & Polyethylene terephthalate & $95.49 \%$ \\
\hline Colorless & 1.2 & Polyethylene terephthalate & $95.37 \%$ \\
\hline Red & 2.8 & Cellulose acetate & $95.24 \%$ \\
\hline Colorless & 7.8 & Polyester & $95.19 \%$ \\
\hline Black & 0.9 & Polyethylene terephthalate & $94.93 \%$ \\
\hline Gray & 2.7 & Cellulose acetate & $94.66 \%$ \\
\hline Colorless & 1.8 & Polyethylene terephthalate & $94.60 \%$ \\
\hline Colorless & 0.8 & Polyethylene terephthalate & $94.02 \%$ \\
\hline Colorless & 1.1 & Polyester & $93.14 \%$ \\
\hline Colorless & 0.6 & Polyethylene terephthalate & $92.45 \%$ \\
\hline Colorless & 0.7 & Polyethylene terephthalate & $92.10 \%$ \\
\hline Colorless & 2.9 & Cellulose & $92.09 \%$ \\
\hline Colorless & 2.2 & Cellulose acetate & $91.95 \%$ \\
\hline Black & 0.6 & Polyethylene terephthalate & $91.85 \%$ \\
\hline Colorless & 1.5 & Polyethylene terephthalate & $91.32 \%$ \\
\hline Colorless & 0.7 & Cellulose & $90.61 \%$ \\
\hline Red & 6.4 & Cellulose acetate & $90.39 \%$ \\
\hline Colorless & 1.0 & Cellulose acetate & $89.96 \%$ \\
\hline Black & 0.8 & Cellulose acetate & $89.85 \%$ \\
\hline Colorless & 1.9 & Polyethylene terephthalate & $89.55 \%$ \\
\hline Colorless & 1.9 & Polyethylene terephthalate & $89.33 \%$ \\
\hline Blue & 0.4 & Polyethylene terephthalate & $89.21 \%$ \\
\hline Colorless & 1.1 & Polyethylene terephthalate & $88.35 \%$ \\
\hline Colorless & 1.4 & Cellulose & $87.98 \%$ \\
\hline Colorless & 0.7 & Polyethylene terephthalate & $87.82 \%$ \\
\hline Blue & 0.7 & Polyethylene terephthalate & $87.69 \%$ \\
\hline Colorless & 0.7 & Polyethylene terephthalate & $87.15 \%$ \\
\hline Blue & 1.4 & Cellulose acetate & $86.86 \%$ \\
\hline Colorless & 1.0 & Polyethylene terephthalate & $86.77 \%$ \\
\hline Gray & 1.7 & Polyethylene terephthalate & $86.73 \%$ \\
\hline Colorless & 1.2 & Nylon & $86.32 \%$ \\
\hline Colorless & 0.9 & Polyethylene terephthalate & $85.80 \%$ \\
\hline Gray & 2.6 & Cellulose & $85.65 \%$ \\
\hline Colorless & 1.1 & Polyethylene terephthalate & $85.64 \%$ \\
\hline Blue & 2.2 & Cellophane & $85.48 \%$ \\
\hline Colorless & 1.2 & Cellulose & $84.47 \%$ \\
\hline Colorless & 0.8 & Cellulose & $82.95 \%$ \\
\hline Blue & 1.5 & Cellulose acetate & $82.50 \%$ \\
\hline Colorless & 4.5 & Polyester & $81.98 \%$ \\
\hline Gray & 0.9 & Cellophane & $81.26 \%$ \\
\hline Blue & 2.5 & Cellulose & $80.00 \%$ \\
\hline Blue & 1.0 & Cellulose & $79.00 \%$ \\
\hline Gray & 1.6 & Cellulose acetate & $78.46 \%$ \\
\hline Colorless & 1.2 & Cellulose & $78.12 \%$ \\
\hline Colorless & 1.7 & Cellulose acetate & $77.02 \%$ \\
\hline Blue & 1.8 & Cellophane & $74.75 \%$ \\
\hline Blue & 2.3 & Cellulose & $74.39 \%$ \\
\hline Gray & 1.0 & Cellophane & $74.32 \%$ \\
\hline Black & 2.4 & Cellophane & $71.93 \%$ \\
\hline Blue & 1.1 & Cellophane & $71.90 \%$ \\
\hline Gray & 1.3 & Low spectral match & $64.29 \%$ \\
\hline
\end{tabular}


APPENDIX J: CHAPTER 3. Example FTIR-ATR spectra of microplastics isolated from Olympic Coast razor clams, stacked along with the two highest percentage matches from Omnic, Primpke et al. 2018 and Primpke et al. 2020 FTIR polymer databases for a: A) Polyethylene Terephthalate fiber (1.9mm total length); and B) Cellulose acetate fiber (3.2mm total length).
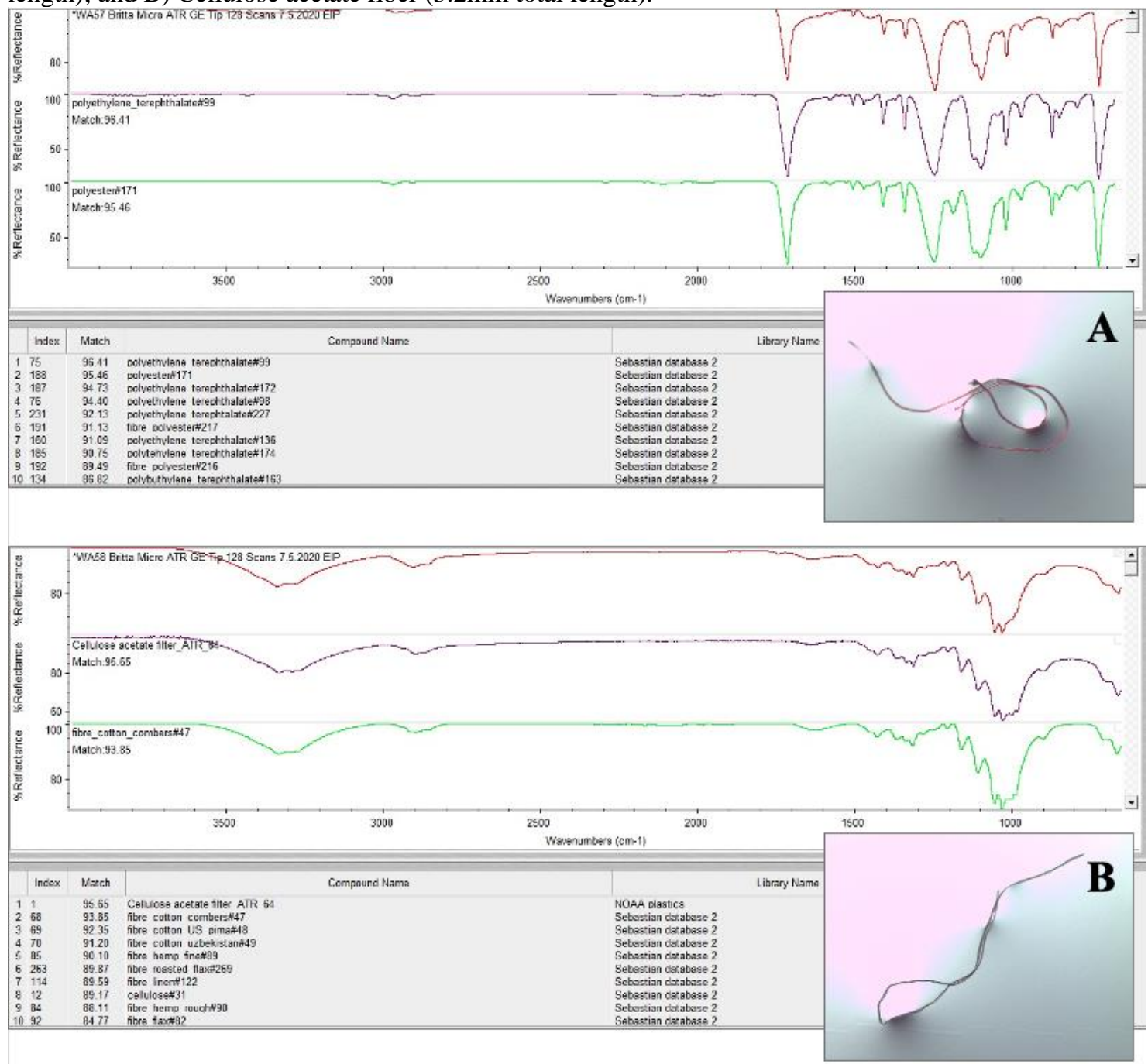


\section{Chapter 4}

APPENDIX K: CHAPTER 4. Aerial schematic of the ocean plastic exhibit at the Oregon Coast Aquarium. Exhibit dimensions were approximately 12 x $10 \mathrm{ft}$.

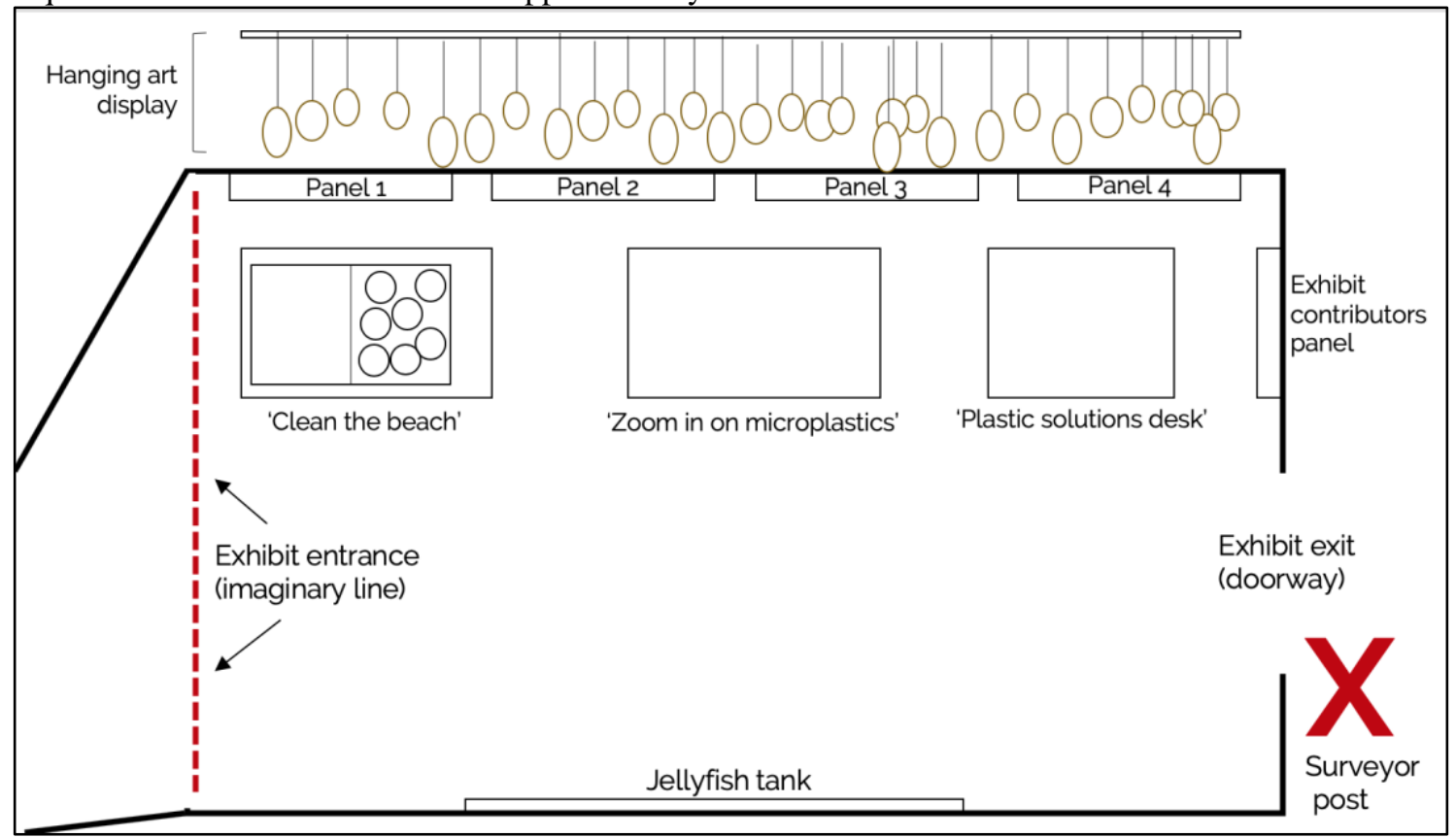

APPENDIX L: CHAPTER 4. Layout and content of wall panels at the Oregon Coast Aquarium ocean plastic exhibit.

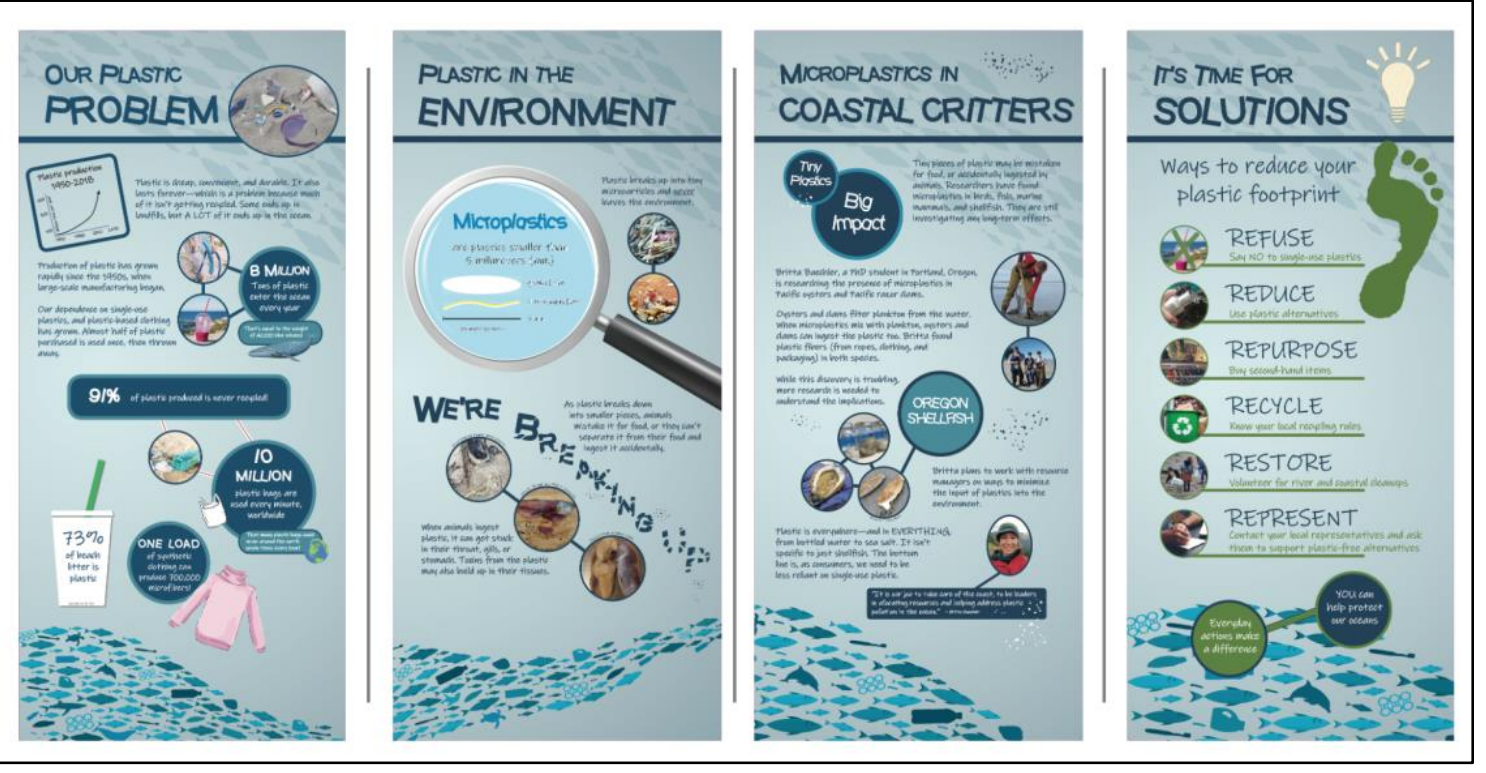


APPENDIX M: CHAPTER 4. Cartoon zine booklet created by Nini Bui and Britta Baechler for the ocean plastic exhibit at the Oregon Coast Aquarium. A laminated, spiral-bound copy was mounted to the Plastic Solutions Desk with paracord.

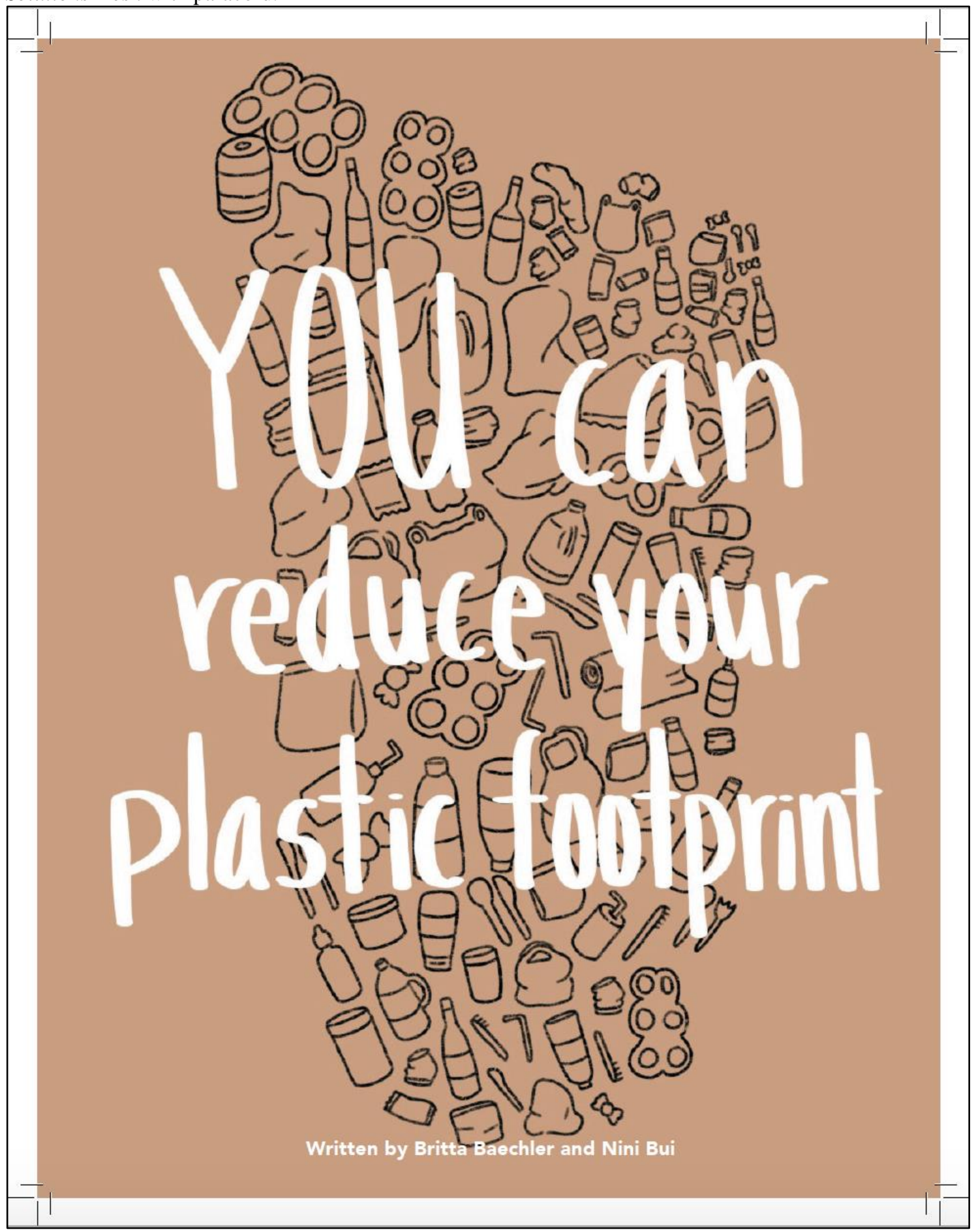




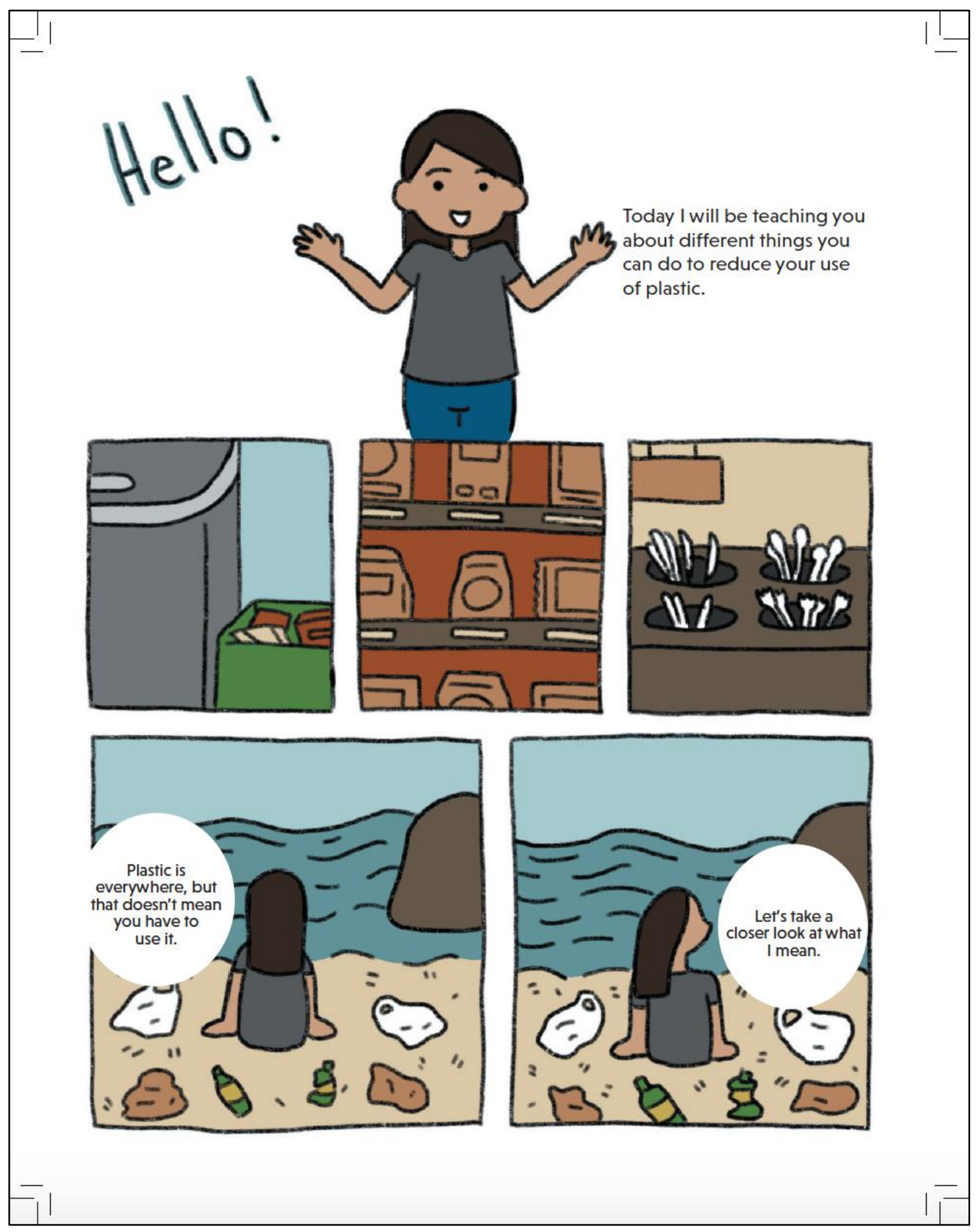




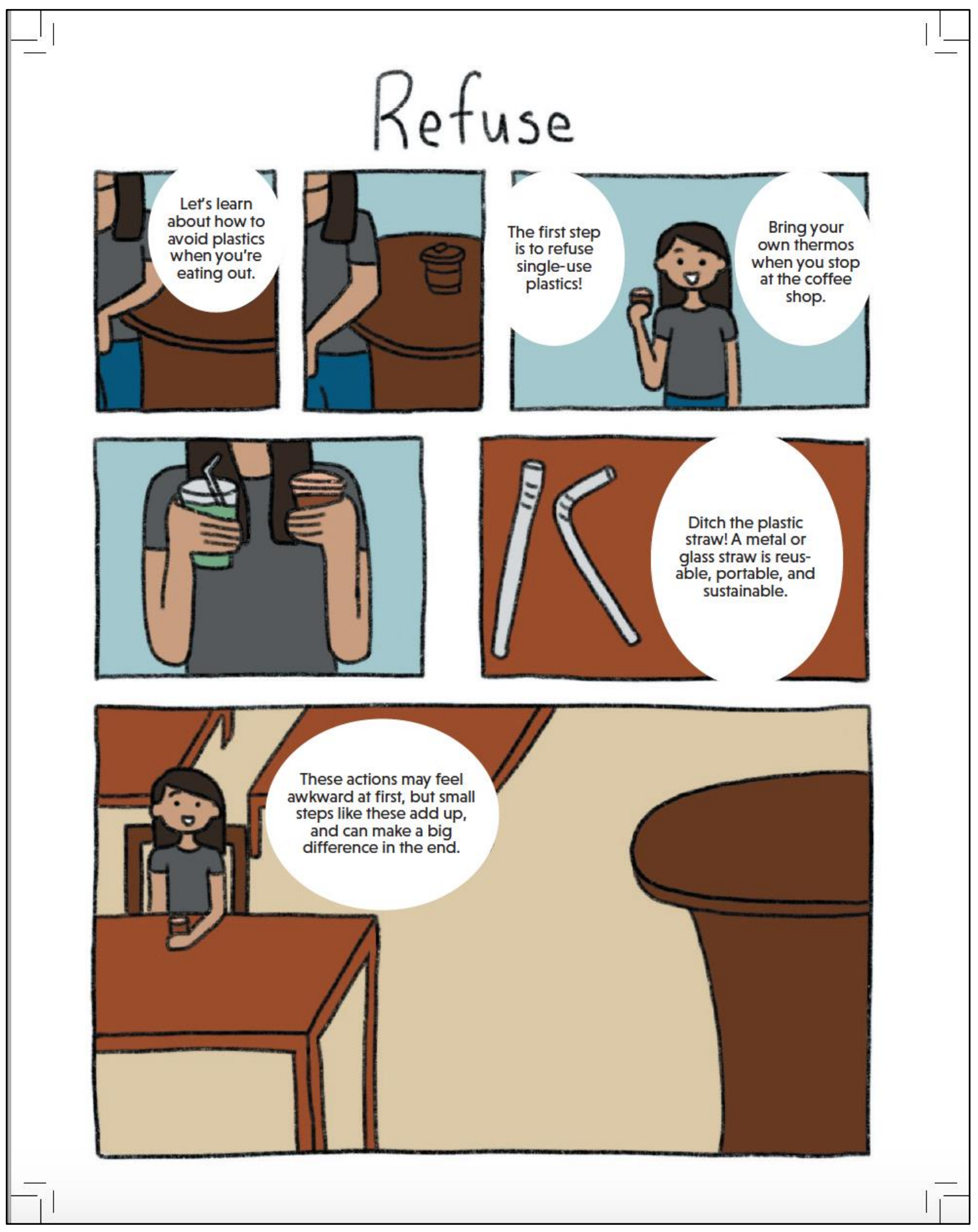




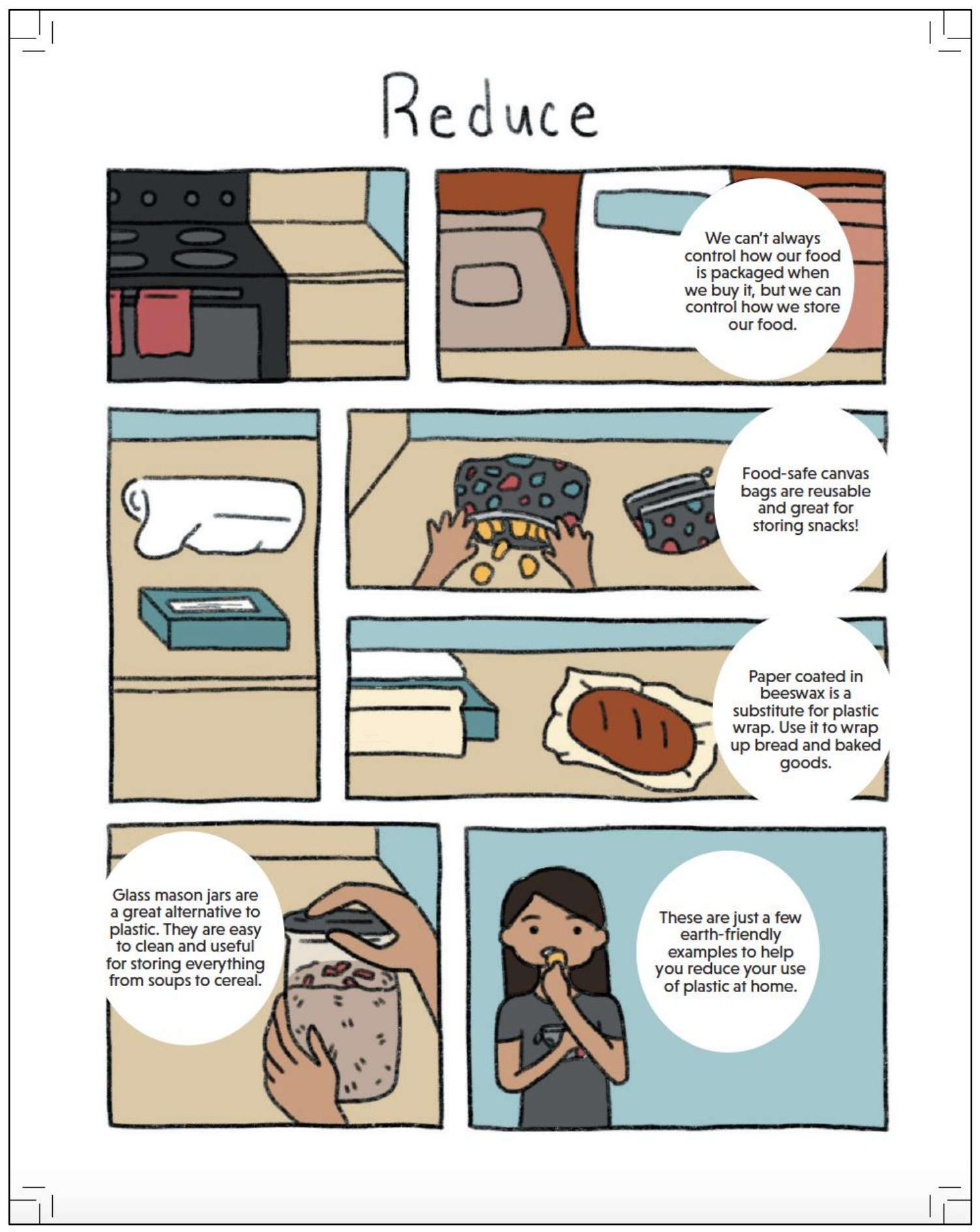




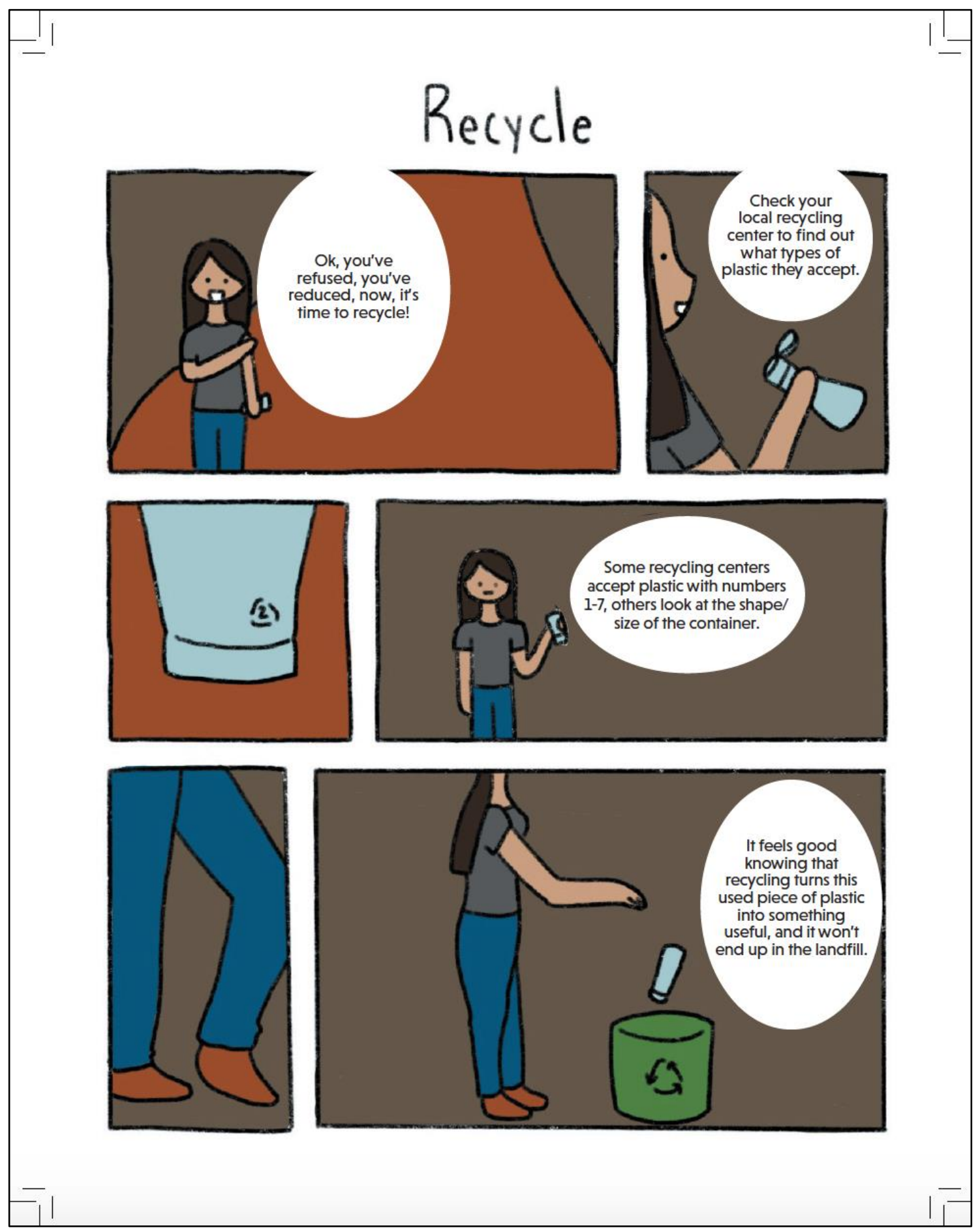




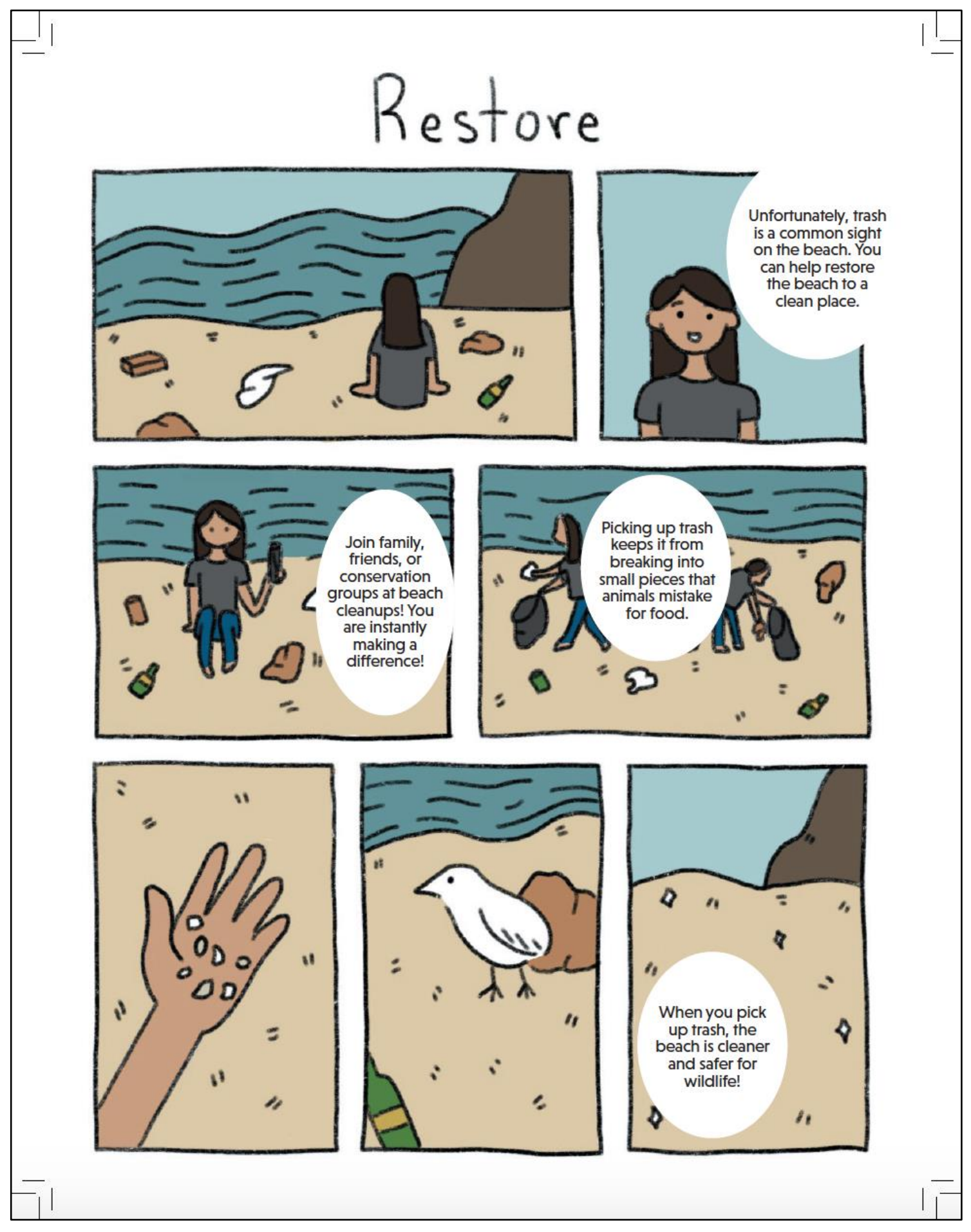




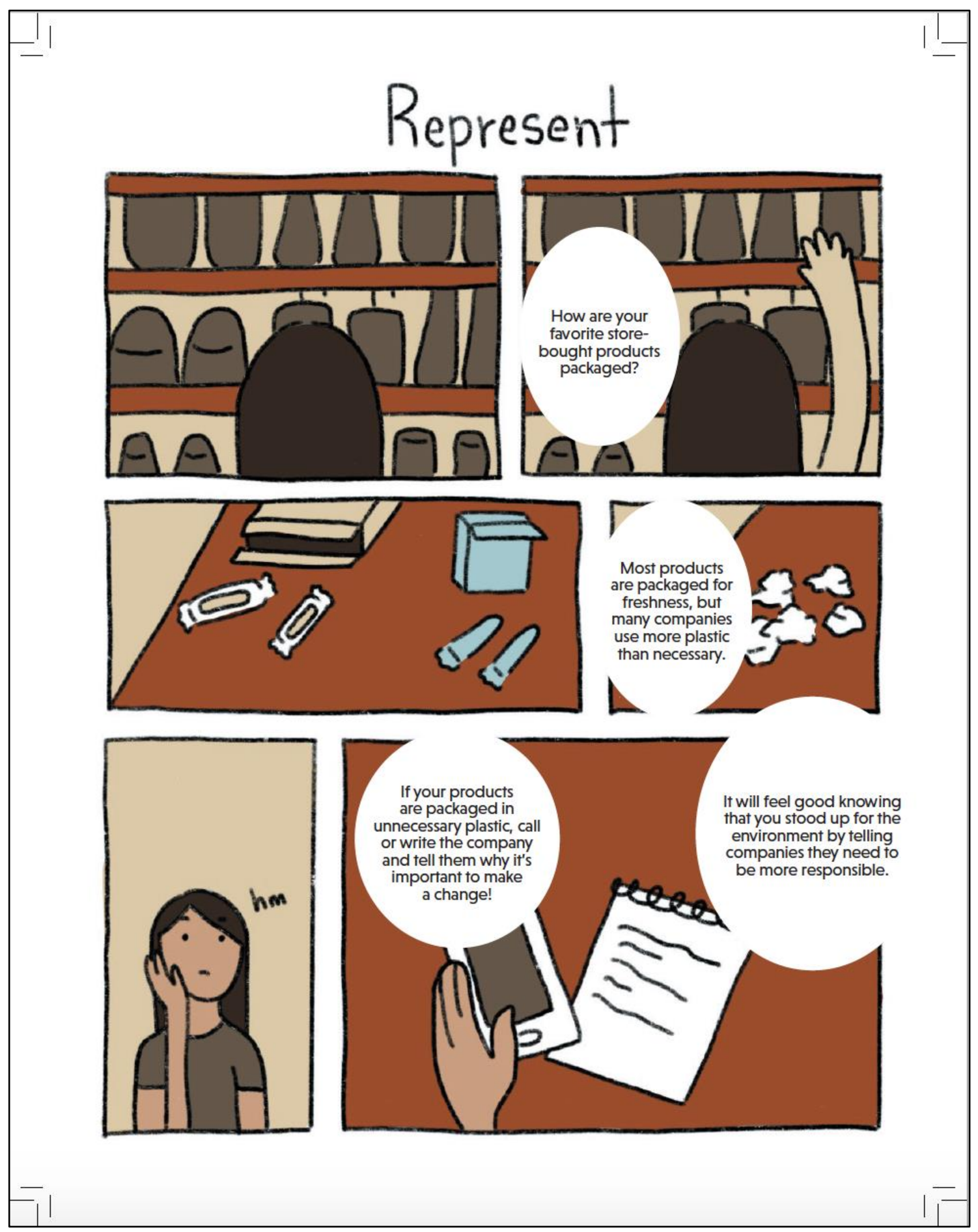




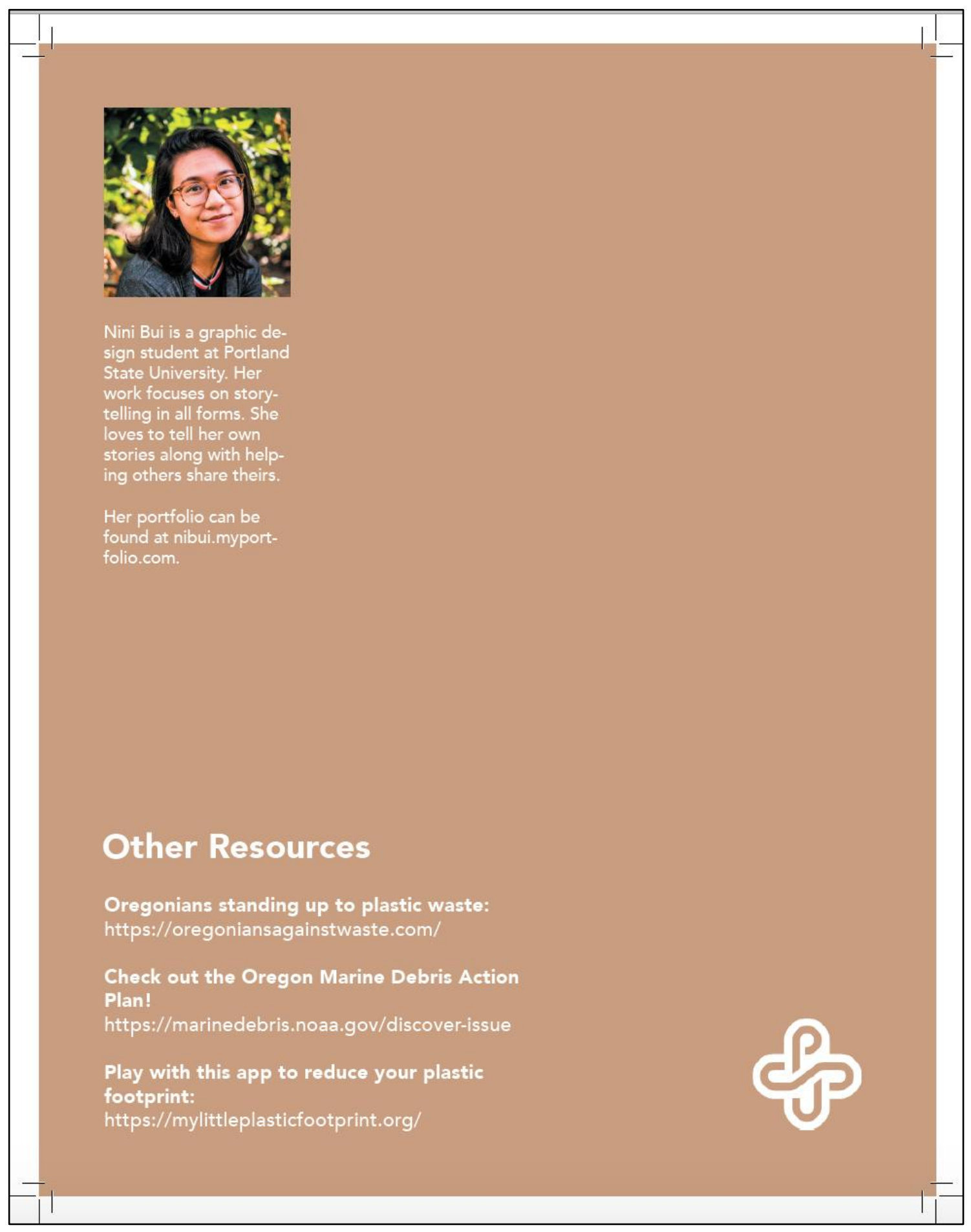


APPENDIX N: CHAPTER 4. Structured questionnaire administered to Oregon Coast Aquarium visitors in August and November 2019.

SURVEY I.D.

Interview date: /'19 Time: AM PM Interviewer initials:

1. Is this your first time to the Oregon Coast Aquarium? Yes No I don't know

2. Was this your first time seeing the Marine Plastics exhibit? Yes No I don't know 1A. IF NO, how many times have you visited the exhibit before?

3. What do you think the Aquarium was trying to get across to people with this exhibit?

5. How would you finish this sentence: "Before visiting this exhibit, I never realized that..."

6. How would you finish this one: "Seeing this exhibit reminded me that..."

7. What did you like best about the exhibit?

8. On a scale of 'Strongly disagree' to 'strongly agree': I learned from interacting with this exhibit

Strongly Disagree $\quad$ Disagree Neutral Agree Strongly Agree

9A. If children in the group interacted with the exhibit, what did they like best?

9B. (If children in the group interacted with exhibit- ask parents): Please answer this statement on a scale of 'Strongly disagree' to 'strongly agree': My child learned from interacting with this exhibit
Strongly Disagree
Disagree
Neutral
Agree
Strongly Agree 
SURVEY I.D.

9C. (Only if their rating on 9B is 'Disagree' or 'Strongly disagree': Can you describe why you think the exhibit didn't work well for your child?

10. Were there any parts of the exhibit that you felt were confusing, and how can the exhibit be improved?

15. How would you rate your overall impression of this exhibit? $(0-4,0$ is low, 4 is high)

$\begin{array}{lllll}0 & 1 & 2 & 3 & 4\end{array}$

11A. Before coming to this exhibit, how would you have rated your desire to help address the marine plastics problem? (0-4, 0 is low, 4 is high)

$\begin{array}{lllll}0 & 1 & 2 & 3 & 4\end{array}$

11B. How would you rate your desire to help address the marine plastics problem now? $(0-4,0$ is low, 4 is high)

$\begin{array}{lllll}0 & 1 & 2 & 3 & 4\end{array}$

11C. (Only if their rating on Q11B is lower than Q11A) I noticed you rated your interest lower after seeing the exhibit. Can you describe why you think that is?

13. What are the first two positive words that come to mind when you hear the word 'plastic'?

14. What are the first two negative words that come to mind when you hear the word 'plastic'?

QUESTIONS 4 \&17-20 on separate sheet (MAKE SURE SURVEY ID is present) 
SURVEY I.D.

Question 4: How often do you do the following things in your life?

(Circle one number per horizontal row)

\begin{tabular}{|c|c|c|c|c|c|c|}
\hline & N/A & Never & $\begin{array}{l}\text { Rarely, I have } \\
\text { done this a } \\
\text { couple of } \\
\text { times }\end{array}$ & $\begin{array}{c}\text { Sometimes, } \\
\text { about once } \\
\text { or twice a } \\
\text { week }\end{array}$ & $\begin{array}{c}\text { Frequently, } \\
\text { three or } \\
\text { more days a } \\
\text { week }\end{array}$ & $\begin{array}{c}\text { Almost } \\
\text { everyday }\end{array}$ \\
\hline $\begin{array}{l}\text { Carry a reusable } \\
\text { water bottle }\end{array}$ & & 0 & 1 & 2 & 3 & 4 \\
\hline $\begin{array}{l}\text { Bring your own } \\
\text { bag to the store or } \\
\text { market }\end{array}$ & & 0 & 1 & 2 & 3 & 4 \\
\hline $\begin{array}{l}\text { Use a reusable } \\
\text { straw (ex: metal, } \\
\text { glass, bamboo) }\end{array}$ & & 0 & 1 & 2 & 3 & 4 \\
\hline $\begin{array}{l}\text { Bring your own } \\
\text { refillable coffee } \\
\text { container }\end{array}$ & & 0 & 1 & 2 & 3 & 4 \\
\hline $\begin{array}{l}\text { Choose items not } \\
\text { packaged in } \\
\text { plastic when } \\
\text { available }\end{array}$ & & 0 & 1 & 2 & 3 & 4 \\
\hline $\begin{array}{l}\text { Specifically ask for } \\
\text { your drink to } \\
\text { come without a } \\
\text { straw }\end{array}$ & & 0 & 1 & 2 & 3 & 4 \\
\hline $\begin{array}{l}\text { Bring your own } \\
\text { containers to } \\
\text { restaurants for } \\
\text { take-out food }\end{array}$ & & 0 & 1 & 2 & 3 & 4 \\
\hline $\begin{array}{l}\text { Carry your own } \\
\text { utensils (forks, } \\
\text { spoons, knifes) }\end{array}$ & & 0 & 1 & 2 & 3 & 4 \\
\hline $\begin{array}{l}\text { Clean the beach } \\
\text { (informal or } \\
\text { formal beach } \\
\text { cleanups) }\end{array}$ & & 0 & 1 & 2 & 3 & 4 \\
\hline $\begin{array}{l}\text { Contact } \\
\text { companies or } \\
\text { representatives to } \\
\text { encourage plastic } \\
\text { reduction }\end{array}$ & & 0 & 1 & 2 & 3 & 4 \\
\hline
\end{tabular}

After completing the table, place 1 or 2 stars to the left of the actions you expect to start doing or increase ( 1 star= probably will do, $\mathbf{2}$ stars= definitely will do). 
SURVEY I.D.

18. Who are you visiting the aquarium with today? (Check 1 box)

$\square$ Family or friends (including kids younger than 18)

- If kids in the group, what are their ages? (please write in)

$\square$ Family or friends (all adults)

$\square$ By myself

$\square$ Organized group (camp, scouts, tour, etc.)

19. What is your gender? (Circle one) Female Male I identify my gender differently

20. What is your age? (Circle one) $\quad 18-29 \quad 30-39 \quad 40-49 \quad 50-59 \quad 60-69 \quad 70-79 \quad 80+$

21. What is your zipcode?

$* * * * * * * * * *$ Survey complete. Thank you for participating! 
APPENDIX O: CHAPTER 4. Conceptual diagram showing data collection options for Oregon Coast Aquarium visitors entering the ocean plastic exhibit. Structured questionnaires were administered to randomly selected individuals that verbally confirmed they were 18 years of age or older.

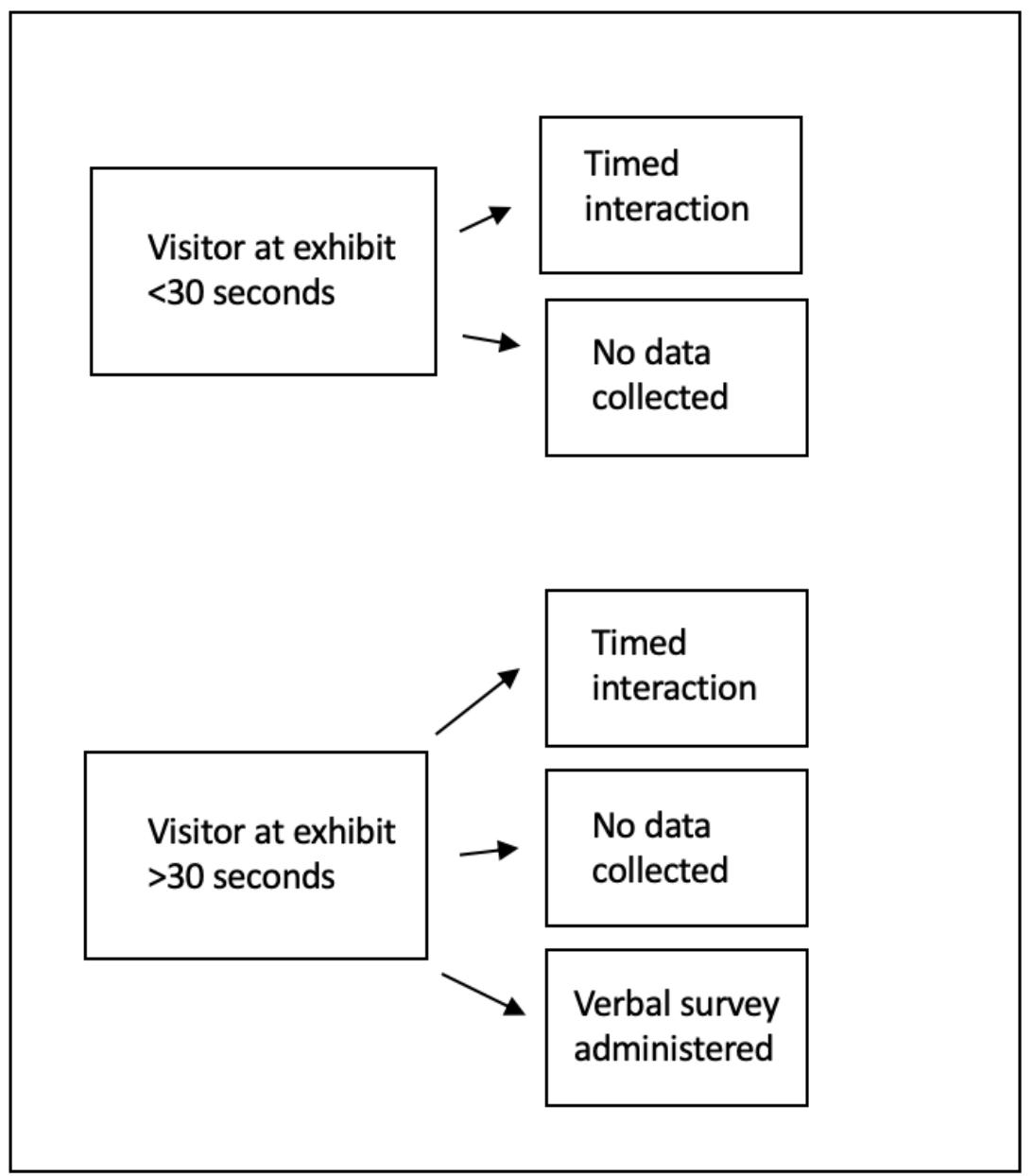


APPENDIX P: CHAPTER 4. Datasheet for timed interaction survey data collected at the Oregon Coast Aquarium in August and November 2019.

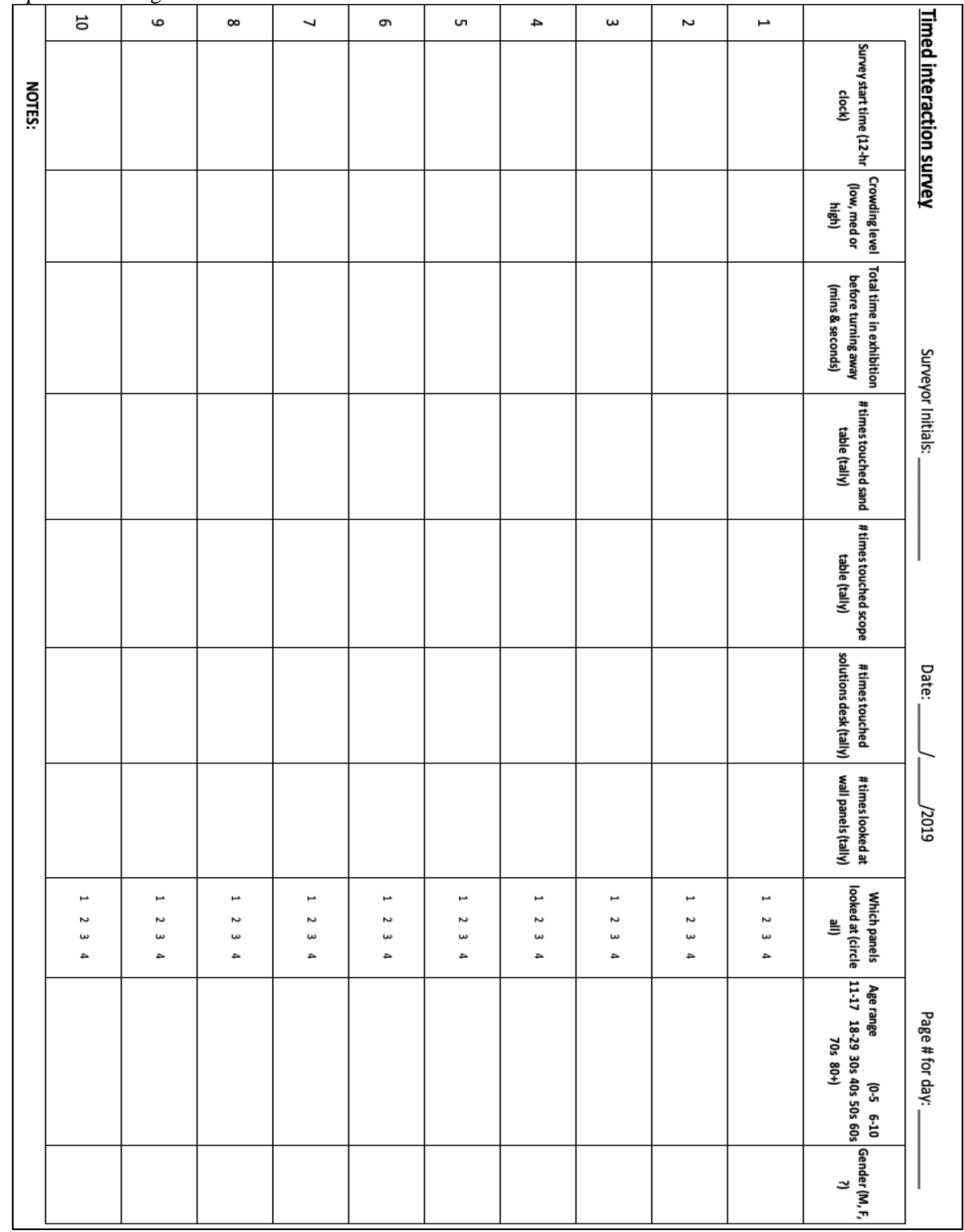


APPENDIX Q: CHAPTER 4. Categorizations for open-ended Oregon Coast Aquarium ocean plastic exhibit questionnaire responses (Questions 3, 5, 6, 7, 9A, 10,13,14) thematically coded by the Applied Coastal Ecology (ACE) lab group at Portland State University. A percent agreement score for each question was generated, calculated as the percent similarity of response categorization between ACE and the paper's lead author. Final categorizations were determined by the lead author.

\begin{tabular}{|c|l|c|c|c|c||}
\hline Question \# & \multicolumn{1}{c|}{ Question posed } & $\begin{array}{c}\text { Number of } \\
\text { responses }\end{array}$ & $\begin{array}{c}\text { Number of } \\
\text { categorizations }\end{array}$ & $\begin{array}{c}\text { Number of } \\
\text { categories }\end{array}$ & $\begin{array}{c}\text { Percent } \\
\text { agreement }\end{array}$ \\
\hline 3 & $\begin{array}{l}\text { "What do you think the Aquarium } \\
\text { was trying to get across to people } \\
\text { with this exhibit?" }\end{array}$ & 92 & 156 & 16 & $\mathbf{9 4 . 8 7 \%}$ \\
\hline 5 & $\begin{array}{l}\text { "Before visiting this exhibit, I never } \\
\text { realized that..." }\end{array}$ & 84 & 116 & 13 & $\mathbf{8 4 . 4 8 \%}$ \\
\hline 6 & $\begin{array}{l}\text { "Seeing this exhibit reminded me } \\
\text { that.." }\end{array}$ & 87 & 136 & 13 & $\mathbf{8 5 . 2 9 \%}$ \\
\hline 7 & $\begin{array}{l}\text { "What did you like best about the } \\
\text { exhibit?" }\end{array}$ & 93 & 115 & 9 & $\mathbf{8 7 . 8 3 \%}$ \\
\hline $9 \mathrm{~A}$ & $\begin{array}{l}\text { "If children in the group interacted } \\
\text { with the exhibit, what did they like } \\
\text { best?" }\end{array}$ & 66 & 100 & $\mathbf{9 4 . 0 0 \%}$ \\
\hline 10 & $\begin{array}{l}\text { "Were there any parts of the exhibit } \\
\text { that you felt were confusing, and } \\
\text { how can the exhibit be improved?" }\end{array}$ & 93 & 109 & 9 & $\mathbf{9 0 . 8 3 \%}$ \\
\hline 13 & $\begin{array}{l}\text { "What are the first two positive } \\
\text { words that come to mind when you } \\
\text { hear the word "plastic'?" }\end{array}$ & $144^{*}$ & 144 & 10 & $\mathbf{9 7 . 2 2 \%}$ \\
\hline 14 & $\begin{array}{l}\text { "What are the first two negative } \\
\text { words that come to mind when you } \\
\text { hear the word 'plastic'?" }\end{array}$ & $164^{*}$ & 164 & $\mathbf{9}$ & $\mathbf{9 5 . 1 2 \%}$ \\
\hline \hline
\end{tabular}

Note: *= Represents up to two answers per respondent. 
APPENDIX R: CHAPTER 4. Thematically categorized open-ended responses by 93 Oregon Coast Aquarium visitors for the first two- A) positive words that come to mind when you hear the word 'plastic'; and B) negative words that come to mind when you hear the word 'plastic'. Top five responses by frequency are represented in blue, remaining responses are represented in gray. Not all respondents provided two words each. Non-responses were not included.

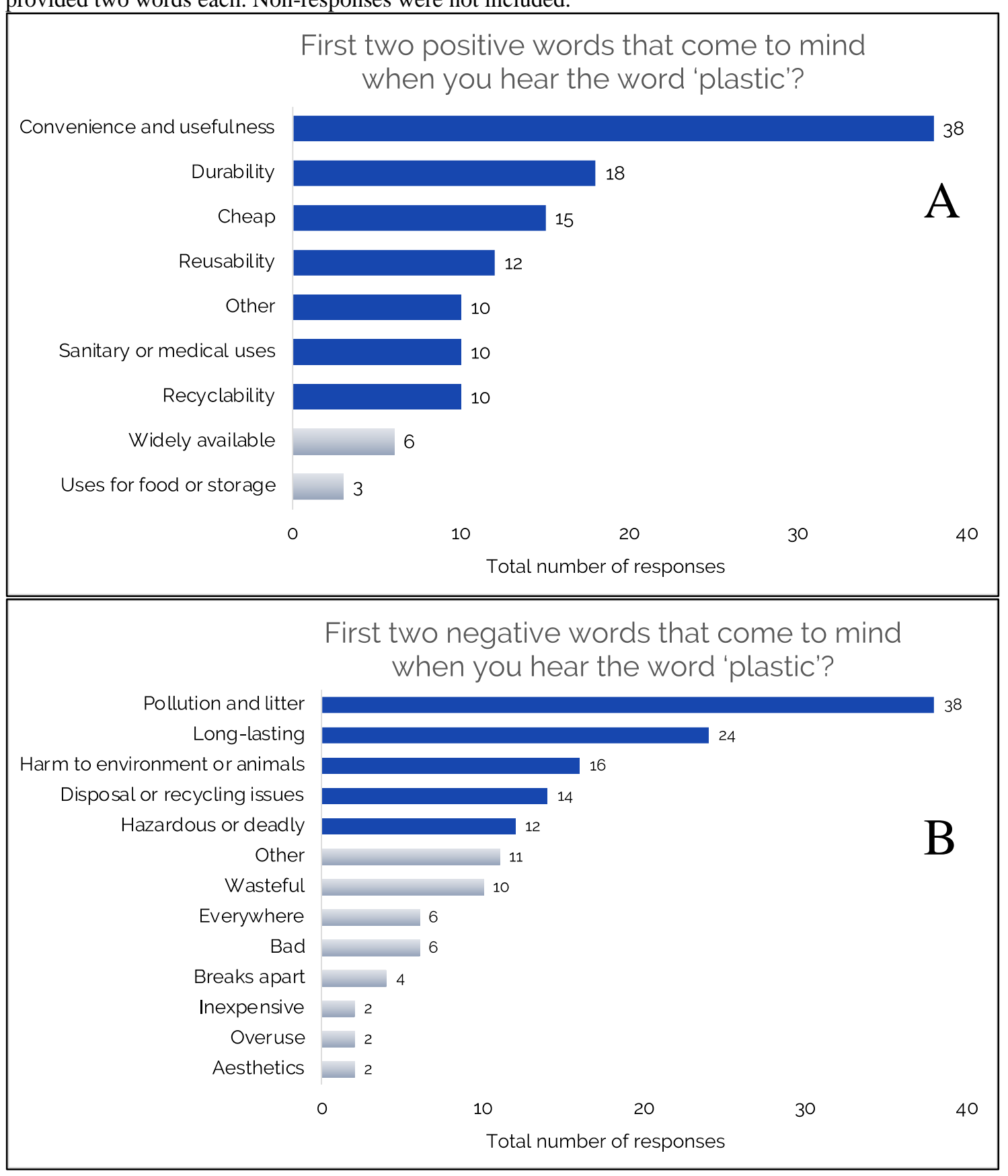


APPENDIX S: CHAPTER 4. Mean, Median and Mode responses for 91 Oregon Coast Aquarium visitors who self-reported single-use plastic reduction or plastic stewardship actions. Actions are sorted left to right from highest to lowest mean response. $0=$ Never; $1=$ Rarely (I have done this a couple of times); $2=$

Sometimes (about once or twice a week); $3=$ Frequently (three or more days a week); $4=$ Almost every day.

\begin{tabular}{|c|c|c|c|c|c|c|c|c|c|c|}
\hline & $\begin{array}{c}\text { Carry a } \\
\text { reusable } \\
\text { water bottle }\end{array}$ & $\begin{array}{c}\text { BYo coffee } \\
\text { container }\end{array}$ & $\begin{array}{c}\text { BYo bag } \\
\text { to store or } \\
\text { market }\end{array}$ & $\begin{array}{c}\text { Choose items } \\
\text { not packaged } \\
\text { in plastic }\end{array}$ & $\begin{array}{c}\text { Specifically } \\
\text { ask for no } \\
\text { straw }\end{array}$ & $\begin{array}{c}\text { Use a } \\
\text { reusable } \\
\text { straw }\end{array}$ & $\begin{array}{c}\text { Clean } \\
\text { the } \\
\text { beach }\end{array}$ & $\begin{array}{c}\text { Carry your } \\
\text { own } \\
\text { utensils }\end{array}$ & $\begin{array}{c}\text { Contact } \\
\text { companies or } \\
\text { representatives }\end{array}$ & $\begin{array}{c}\text { BYo } \\
\text { containers to } \\
\text { restaurants }\end{array}$ \\
\hline Mean & 3.4 & 2.6 & 2.5 & 2.1 & 1.7 & 1.6 & 1.5 & 1.0 & 0.4 & 0.4 \\
\hline Median & 4 & 3 & 3 & 2 & 1 & 1 & 1 & 0 & 0 & 0 \\
\hline Mode & 4 & 4 & 4 & 2 & 0 & 0 & 1 & 0 & 0 & 0 \\
\hline
\end{tabular}

Note: $\mathrm{BYO}=$ Bring your own. NAs and non-responses were not included in mean, median or mode response calculations. 